Guilherme de Andrade Campos Abdalla

\title{
O ESTADO DE EXCEÇÃO EM GIORGIO AGAMBEN CONTRIBUIÇÕES AO ESTUDO DA RELAÇÃO DIREITO E PODER
}

\section{DissertaÇão de MESTRAdo}

Orientador: Professor Titular Tercio SAMPaio Ferraz Jr.

FaCuldade de Direito da Universidade de São Paulo

São PaUlo 
Guilherme de Andrade CAMpos AbDalla

MATríCUlA No 5859484

\title{
O ESTADO DE EXCEÇÃO EM GIORGIO AGAMBEN CONTRIBUIÇÕES AO ESTUDO DA RELAÇÃO DIREITO E PODER
}

\begin{abstract}
Dissertação de Mestrado apresentada como requisito parcial à obtenção do título de Mestre em Direito, na área de concentração Filosofia e Teoria Geral do Direito, sob orientação do Professor Titular Tercio Sampaio Ferraz Jr.
\end{abstract}

Faculdade de Direito da Universidade de São Paulo DePartamento de Filosofia e TeOria Geral do Direito (DFD) São Paulo 
"Un giorno l'umanità giocherà col diritto, come i bambini giocano con gli oggetti fuori uso, non per restituirli al loro uso canonico, ma per liberarli definitivamente da esso".

"Um dia, a humanidade brincará com o direito, como as crianças brincam com os objetos fora de uso, não para devolvê-los a seu canônico e, sim, para libertá-los definitivamente dele". Giorgio Agamben 
A meus pais, Maurício e Néli, poesia pura de uma magia sem fins. 


\section{AGRADECIMENTOS}

Ao Professor Tercio Sampaio Ferraz Jr., orientador final deste trabalho, e aos Professores Gilberto Bercovici e Márcio Alves da Fonseca, pelo seguro acompanhamento e participação na Banca examinadora.

Ao Professor Eduardo Domingos Bottallo, pelo acolhimento junto à Faculdade de Direito da Universidade de São Paulo.

À Professora Elza Antônia Pereira Cunha Boiteux, por suas valiosas sugestões.

Aos Professores Celso Lafer, Jeannette Antonios Maman, Lídia Reis de Almeida Prado e Eduardo Carlos Bianca Bittar, com quem tive o privilégio de dialogar a filosofia do direito.

À Professora Mônica Herman Salem Caggiano, Presidente da Comissão de PósGraduação da Faculdade de Direito da Universidade de São Paulo, e ao Sr. Mário Sérgio de Oliveira e Silva, Chefe Administrativo de Serviço da Secretaria da Faculdade de Direito da Faculdade de São Paulo, pelas firmes e contínuas providências administrativas que possibilitaram o depósito desta dissertação de mestrado.

Aos familiares e amigos. 
$\begin{array}{ll}\text { RESUMO } & 8\end{array}$

ABSTRACT 9

POR QUE LER AGAMBEN, HOJE 10

INTRODUÇÃO 33

1 OBJETO INVESTIGADO: IDENTIFICAÇÃO DO DESAFIO AGAMBENIANO 33

2 OBJETIVO, ATUALIDADE E LIMITES 36

3 PlaNO DA OBRA 41

1 BIOPODER 43

$\begin{array}{lll}1.1 & \text { POLITIZAÇ̃̃o DA VIDA } & 44\end{array}$

1.1.1 A emergência da biopolítica 44

1.1.2 Direito de vida e de morte 47

$\begin{array}{lll}\text { 1.1.3 Biopolítica e disciplina } & 50\end{array}$

1.1.4 O novo corpo biopolítico 53

$\begin{array}{lll}1.1 .5 & \text { A vida nua } & 57\end{array}$

1.1.6 Biopolítica e totalitarismo moderno 63

2 ESTADO DE EXCEÇÃO 68

2.1 A ONTOLOGia DA POTÊNCIA 70

2.2 O DEBATE ENTRE GIGANTES 76

2.2.1 Agamben e os gigantes 98

2.3 O ESTADO DE EXCEÇÃO EM AGAMBEN 102

$\begin{array}{lll}2.3 .1 \text { A exclusão inclusiva } & 102\end{array}$

2.3.2 Direitos de exceção e anomia jurídica 117

2.3.3 Estado de exceção, linguagem e força-de-łei 123

$\begin{array}{lll}2.3 .4 & \text { Biopolítica, norma e exceção } & 131\end{array}$ 
2.3.5 A fundação da cidade moderna

2.3.6 Poder constituinte e estado de exceção

2.4 A RELAÇÃO DE ABANDONO 148

2.5 O HOMO SACER 157

2.6 O CAMPO MODERNO 165

3 A VIDA-FELIZ 185

CONSIDERAÇÕES FINAIS 196 BIBLIOGRAFIA 202 


\section{RESUMO}

A complexa filosofia de Giorgio Agamben convoca-nos a compreender a crise dos atuais modelos político-governamentais e a hodierna lógica da segurança que, sob a doutrina do medo orquestrado, visa à eliminação dos não-integráveis, como igualmente nos convida a abarcar na defesa de uma nova ontologia política além da tradição da soberania e do direito. Do confronto entre as conceituações semânticas do termo vida e da relação desta com o poder soberano, inclusive numa sociedade biopolítica de normalização, emerge o protagonista da obra agambeniana, a vida nua. Uma vida que não é inauguração moderna, mas atividade originária do poder soberano, quer dizer, uma vida que pode ser detectada tanto na pólis e na civitas - na figura do homo sacer -, assim como no totalitarismo moderno e, rasteiramente, na democracia em que vivemos. Trata-se de uma vida absolutamente matável e exposta à morte que, fundada numa relação de exclusão inclusiva, isto é, de abandono, revela o verdadeiro vínculo social. O que une vida e lei, violência e norma, é o estado de exceção. A norma se aplica à exceção desaplicando-se: a força-de-tei exercida no estado de exceção não põe, nem conserva, o direito, mas o conserva suspendendo-o e o põe excetuando-se. Uma figura em que factum e ius tornam-se indiscerníveis e homines sacri são produzidos a esmo; um espaço onde distinções políticas tradicionais como direita e esquerda, público e privado, perdem sua clareza e inteligibilidade. Uma indiscernibilidade que pode ser materializada no campo, seja de refugiados, seja de concentração, seja o hoje vigente e ainda inominado, de modo que o campo reflete o próprio paradigma da atualidade. Esta é a era da exceção em permanência. O caminho para a desativação dessa relação é a profanação, figura em que se busca uma nova forma-de-vida que não seja inaugurada pela lembrança teológica da política soberana e do direito, mas que reflita uma comunidade que vem capaz de desativar a máquina biopolítica produtora da vida nua e torne inoperante o atual conceito de político-jurídico: uma nova comunidade que pense além da soberania, do bando soberano e do próprio direito. Trata-se de uma comunidade de singularidades, sem identidade, sem propriedades e destinos, mas que seja pura potencialidade, que seja em si como ela é, quer dizer, que não possua qualquer tarefa enquanto fim, mas tão somente meios sem fins. 


\section{ABSTRACT}

The complex philosophy of Giorgio Agamben summons us to review the crisis of the existing political-juridical models and the on-going governmental security rationale, which, based on a pre-oriented administration of fear, aims at eliminating those somehow non-adapted, as well as to join a defence towards a new political ontology beyond the tradition of sovereignty and law. Through the confront of semantically distinct definitions of life and its relation with the sovereign power, including under a biopolitical normalizing society, emerges the protagonist of Agamben`s work, the bare life. A life that is not a modern phenomena but the original activity of the sovereign power, that is, a life exposed to death that can be found either in the pólis or the civitas - in the form of homo sacer - or in the modern totalitarianism as well as the democracy that we live in. A life that is permanently subject to death and, founded on an inclusive exclusion relation, that is, a relation of abandonment, exposes the real social bound. The state of exception links life and law, violence and norm. The law is applied through its own withdrawal: the force-oftaw exercised in the state of exception does not posit nor conserve the law, but conserves it through its suspension and posits it through the exception. A place where factum and ius are brought into conjunction and homines sacri are freely produced, a space where traditional political categories such as right and left, public and private, loses clearness and intelligibility. A zone of indistinction materialized in the camp, either of refugees or concentration camps or those in full force and effect and yet unnamed. The camp is the contemporary political paradigm and this is the era in which the exception becomes the rule. The way out to deactivate such relation is to profane, a political task in search for a new form-of-life that abolishes any remembrance of theological sovereign politics and law and that reflects a coming community able to turn inoperative the biopolitical machine producer of bare life: a new community that thinks beyond sovereignty, the sovereign band and the law itself. A community composed of singularities, with no identity nor properties or destinies, but pure potentiality. A community free of means in search for an end, but solely a community of pure means without ends. 


\section{POR QUE LER AGAMBEN, HOJE ${ }^{1}$}

Muitas são as razões, porquanto estamos diante de um dos maiores filósofos da atualidade, um pensador-chave cuja doutrina não somente nos ajuda a compreender os problemas conjunturais de nossa época ${ }^{2}$, mas igualmente a abarcar na defesa apaixonada de uma nova política além da tradição da soberania e do direito. Trata-se de um pensador que, com olhar crítico do passado, propõe uma reação imediata rumo ao reencantamento do mundo, rumo à pureza já esquecida. Uma provocante tarefa que, à primeira vista, exerce espantoso fascínio, mas que, a pouco e pouco, pode soar demasiadamente inatingível.

Giorgio Agamben nasceu em Roma, em 1942, e, muito embora fosse ávido leitor de literatura e filosofia, optou pela faculdade de direito, formando-se pela Universidade de Roma, em 1965, com trabalho - não publicado - sobre o pensamento político de Simone Weil. Amigo do cineasta Pier Paolo Pasolini, Agamben atuou no filme ${ }^{3} O$ evangelho segundo São Mateus (1964) no papel do apóstolo Filipe. Isso revela, desde já, a atenção que Agamben confere à teologia - certamente um dos temas de mais difícil compreensão em sua obra -, ao lado do direito ${ }^{4}$, os quais, posteriormente, serão problematizados na dialética entre teologia política e teologia econômica 5 .

\footnotetext{
${ }^{1}$ A escolha do título não se deu ao acaso, mas procura seguir o mesmo telos demonstrado por Tercio Sampaio Ferraz Jr. no prólogo de obra centralizada no pensamento de Hans Kelsen. In: COELHO, Fábio Ulhoa. Para entender Kelsen. 5. ed. São Paulo: Saraiva, 2009.

2 Cf. Jasson da Silva MARTINS. In: Estado de exceção e biopolítica segundo Giorgio Agamben. Entrevista concedida em 4.9.2007. Instituto Humano Unisinos. Disponível em http://www.unisinos.br/ihu/index.php?option=com_noticias\&Itemid=18\&task. Acessado em 22.10.2007.

3 O cinema é um dos diversos temas da filosofia de Agamben principalmente porque, como elucida DEBORAH LEVITT, para o italiano o ser humano é o único animal que se interessa por sua própria imagem, porquanto outros animais notariam sua imagem somente na extensão em que a confundem com a realidade. Assim, o ser humano poderia ser qualificado como the moviegoing animal. In: LEVITT, Debora. Notes on media and biopolitics: 'notes on gesture'. In: CLEMENS, Justin; HERON, Nicholas, MURRAY, Alex (ed.). The work of Giorgio Agamben: law, literature, life. Edinburg University Press, 2008, p. 200.

4 "Primeiramente, gostaria de lembrar que, atualmente, o direito é, de fato, um dos meus principais canteiros de trabalho. O outro é a teologia. Qual a razão desta escolha? Eu poderia responder - e isto não seria necessariamente uma brincadeira - que o direito e a teologia são os dois únicos domínios nos quais Foucault não trabalhou realmente, o que me dava uma certa liberdade”. In: A Política da profanação. Entrevista concedia à Folha de São Paulo em 18.9.2005. Disponível em http://www.geocities.com/vladimirsafatle/vladi081.htm?200722. Acessado em 22.10.2007.

5 "Immediatamente mi è apparso chiaro che dalla teologia cristiana derivano due paradigmi politici in senso lato: la teologia politica, che fonda nell' unico Dio la trascendenza del potere sovrano e la teologia economica, che sostituisce a questa l'idea di una oikonomì, concepita come un ordine immanente domestico e non politico in senso stretto, tanto della vita divina che di quella umana. Dal primo derivano la filosofia politica e la teoria moderna della sovranità; dal secondo, la 'biopolitica' moderna fino all'attuale trionfo dell'economia su ogni aspetto della vita sociale. Il libro che sto scrivendo è nato da questa scoperta. Ho cercato di ricostruire l'origine del concetto teologico di oikonomìa, e poi, nella seconda parte, di seguirne
} 
No verão de 1966, Agamben, então com 24 anos, assistiu aos célebres seminários sobre Hegel e Heráclito proferidos por Martin Heidegger ${ }^{6}$, então com 77 anos, na vila de Le Thor, no sul da França. Agamben descreveu os seminários não como simples conferências, mas como uma constelação - termo comum na doutrina de Walter Benjamin -, um encontro de elementos resultando em algo verdadeiramente inesperado: a filosofia. Mais tarde, Agamben dirá que foram esses seminários que lhe tornaram a filosofia possível, aliás, pode-se dizer que esse verão foi definitivo para que Agamben finalmente unisse direito e filosofia. A partir daí, Agamben reconhece seu desejo de escrever como experiência de pura potencialidade ${ }^{7}$.

Na década de 1970, Agamben dedicou-se aos estudos de linguagem e cultura medieval, primeiro em Paris e depois em Londres, na Warburg Institute Library. Entre 1986 e 1993, Agamben foi diretor de programa no Collège International de Philosophie, Paris, onde estabeleceu vínculo de amizade com Jean-Luc Nancy, Jacques Derrida e JeanFrançois Lyotard, pensadores que são referidos usualmente em suas obras. Nesse período, foi também professor associado de Estética na Universidade de Macerata (1988-1992).

Depois de ter trabalhado como docente de Estética na Universidade de Verona (1993-2003), transferiu-se para Veneza, lecionando a mesma matéria na Facoltà di Design

\footnotetext{
la scomparsa e la secolarizzazione nel moderno. Perché mi pare che questo concetto ad un certo punto scompaia per riemergere con la nascita dell'economia animale e dell'economia politica nel settecento... Quello che mi sembra di poter intravedere da questa ricerca sulla teologia economica è che la storia della nostra cultura, della politica occidentale è la storia delle opposizioni e degli incroci tra un paradigma economico e un paradigma politico in senso stretto. L'economia è l'aspetto gestionale e non normativo, tanto della vita divina che della realtà storica. Riprendendo una citazione schmittiana, ("le roi règne, mais il ne gouverne pas"), si potrebbe chiamare "regno" il primo paradigma e "governo" il secondo. In questa prospettiva, la storia del sistema politico dell'occidente appare come la storia del continuo separarsi e incrociarsi dei due paradigmi. E' evidente che Foucault ha lavorato soprattutto sul secondo, su quello che egli chiama le gouvernement des hommes. Io vorrei lavorare soprattutto sul loro incrocio, anche se è chiaro che oggi sembra essere il secondo a dominare". In: Intervista a Giorgio Agamben: dalla teologia politica alla teologia economica. Rivista online, Scuola superiore dell'economia e delle finanze, anno 1, n. 4, 2004. Disponível em http://rivista.ssef.it/site.php?page=\&edition=2004-04-01. Acessado em 13.6.2009.

${ }^{6}$ Segundo Agamben, "O encontro com Heidegger foi relativamente cedo, e ele inclusive foi determinante em minha formação depois dos seminários de Le Thor, em 1966 e em 1968. Mais ou menos nos mesmos anos durante os quais eu lia Walter Benjamin, leitura que talvez me serviu de antídoto ante o pensamento de Heidegger. Estava em questão o conceito mesmo de filosofia, o modo pelo qual deveria responder à pergunta, prática e teórica ao mesmo tempo: que é a filosofia?". In: Entrevista com Giorgio Agamben. Revista do Departamento de Psicologia, UFF, v. 18, n. 1., janeiro/junho de 2006. Disponível em http://www.scielo.br/scielo.php?pid=S0104-80232006000100011\&script=sci_arttext. Acessado em 18.11.2009.

7 Cf. Leland de la DURANTAYE. In: Giorgio Agamben: a critical introduction. Stanford: Stanford University Press, 2009, p. 2-3.
} 
e Arti della IUAV (Istituto Universitario di Architettura di Venezia). Em 2003, tornou-se Distinguished Professor da New York University, cargo ao qual renunciou em protesto contra a atual biopolítica migratória do governo estadunidense: o Homeland Security Act, que não raramente é intensificado.

Agamben justificou sua atitude em curto artigo publicado no Le Monde, edição de 11 de janeiro de 2004, denominado Non au tatouage biopolitique. Nessa oportunidade, ele comparou, filosoficamente - e isso é feito em diversos momentos de sua obra -, a condição político-jurídica do cidadão nas democracias hodiernas à do detento de Auschwitz. Por ser um ótimo exemplo de sua filosofia aplicada, bem como de sua atitude revolucionária, paixão política e indignação ética ${ }^{8}$, entendemos por bem transcrever o artigo integralmente como nota nesta dissertação ${ }^{9}$, artigo esse que foi subsequentemente criticado por

\footnotetext{
${ }^{8}$ Inquestionáveis características de Agamben de acordo com ANTONIO NEGRI. In: NEGRI, Antonio. Giorgio Agamben: the discreet taste of the dialetic. In: CALARCO, Matthew; DECAROLI, Steven (ed.). Giorgio Agamben: sovereignty and life. Stanford, California: Stanford University Press, 2007, p. 120.

9 "Les journaux ne laissent aucun doute : qui voudra désormais se rendre aux Etats-Unis avec un visa sera fiché et devra laisser ses empreintes digitales en entrant dans le pays. Personnellement, je n'ai aucune intention de me soumettre à de telles procédures, et c'est pourquoi j'ai annulé sans attendre le cours que je devais faire en mars à l'université de New York. Je voudrais expliquer ici la raison de ce refus, c'est-à-dire pourquoi, malgré la sympathie qui me lie depuis de nombreuses années à mes collègues américains ainsi qu'à leurs étudiants, je considère que cette décision est à la fois nécessaire et sans appel et combien je tiendrais à ce qu'elle soit partagée par d'autres intellectuels et d'autres enseignants européens. Il ne s'agit pas seulement d'une réaction épidermique face à une procédure qui a longtemps été imposée à des criminels et à des accusés politiques. S'il ne s'agissait que de cela, nous pourrions bien sûr accepter moralement de partager, par solidarité, les conditions humiliantes auxquelles sont soumis aujourd'hui tant d'êtres humains. L'essentiel n'est pas là. Le problème excède les limites de la sensibilité personnelle et concerne tout simplement le statut juridico-politique (il serait peut-être plus simple de dire biopolitique) des citoyens dans les Etats prétendus démocratiques où nous vivons. On essaie, depuis quelques années, de nous convaincre d'accepter comme les dimensions humaines et normales de notre existence des pratiques de contrôle qui avaient toujours été considérées comme exceptionnelles et proprement inhumaines. Nul n'ignore ainsi que le contrôle exercé par l'Etat sur les individus à travers l'usage de dispositifs électroniques, comme les cartes de crédit ou les téléphones portables, a atteint des limites naguère insoupçonnables. On ne saurait pourtant dépasser certains seuils dans le contrôle et dans la manipulation des corps sans pénétrer dans une nouvelle ère biopolitique, sans franchir un pas de plus dans ce que Michel Foucault appelait une animalisation progressive de l'homme mise en oeuvre à travers les techniques les plus sophistiquées. Le fichage électronique des empreintes digitales et de la rétine, le tatouage sous-cutané ainsi que d'autres pratiques du même genre sont des éléments qui contribuent à définir ce seuil. Les raisons de sécurité qui sont invoquées pour les justifier ne doivent pas nous impressionner: elles ne font rien à l'affaire. L'histoire nous apprend combien les pratiques qui ont d'abord été réservées aux étrangers se trouvent ensuite appliquées à l'ensemble des citoyens. Ce qui est en jeu ici n'est rien de moins que la nouvelle relation biopolitique "normale » entre les citoyens et l'Etat. Cette relation n'a plus rien à voir avec la participation libre et active à la sphère publique, mais concerne l'inscription et le fichage de l'élément le plus privé et le plus incommunicable de la subjectivité : je veux parler de la vie biologique des corps. Aux dispositifs médiatiques qui contrôlent et manipulent la parole publique correspondent donc les dispositifs technologiques qui inscrivent et identifient la vie nue : entre ces deux extrêmes d'une parole sans corps et d'un corps sans parole, l'espace de ce que nous appelions autrefois la politique est toujours plus réduit et plus exigu. Ainsi, en appliquant au citoyen, ou plutôt à l'être humain comme tel, les techniques et les dispositifs qu'ils avaient inventés pour les classes dangereuses, les Etats, qui devraient constituer le lieu même de la vie politique, ont fait de lui le suspect par excellence, au point que c'est l'humanité elle-même qui est devenue la classe dangereuse. Il y a quelques années, j'avais écrit que le paradigme politique de l'Occident n'était plus la cité, mais le camp de concentration, et que nous étions passés
} 
MALCOLM BulL, que, na mesma oportunidade, repreende o próprio homo sacer agambeniano como um conceito frustrantemente dependente de vagas analogias ${ }^{10}$. Em 2006, Agamben recebeu o Prix Européen de l'Essai Charles Veillon pelo l'ensemble de son ceuvre, e é atualmente detentor da cadeira Baruch Spinoza na European Graduate School.

Para seu colega ANTONIO NEGRI, Agamben encaixa-se na geração pós-Segunda Guerra Mundial que, em sua visão, teve influência de elementos da cultura filosófica marxista italiana das décadas de 1960 e 1970, bem como na experiência pós-estruturalista francesa ${ }^{11}$ :

"Let us return to the philosophical climate in Italy during the tumultuous 1960s and 1970s. The thought of Krisis represented the theoretical point of reference for the crisis of Marxism in Italy for quite some time. The erosion of the Marxist theory of value, and the attendant impossibility of bringing it back into line with the rational schema of economic planning or to the political dispositifs that attached themselves to it, determined the - typically Italian (that is, imposed by the high level of struggle) - demand to save communist politics beyond the crisis of communist theory. The philosophy of Krisis unfolded within this framework." 12

É nesse sentido que Agamben pode ser qualificado como um filósofo que, partindo das linhas mestras de Aristóteles, contrasta-se a teoristas contemporâneos e se identifica

d'Athènes à Auschwitz. Il s'agissait évidemment d'une thèse philosophique, et non pas d'un récit historique, car on ne saurait confondre des phénomènes qu'il convient au contraire de distinguer. Je voudrais suggérer que le tatouage était sans doute apparu à Auschwitz comme la manière la plus normale et la plus économique de régler l'inscription et l'enregistrement des déportés dans les camps de concentration. Le tatouage biopolitique que nous imposent maintenant les Etats-Unis pour pénétrer sur leur territoire pourrait bien être le signe avant-coureur de ce que l'on nous demandera plus tard d'accepter comme l'inscription normale de l'identité du bon citoyen dans les mécanismes et les engrenages de l'Etat. C'est pourquoi il faut s'y opposer." In: Non au tatouage biopolitique. Disponível em http:/www.lemonde.fr/cgibin/ACHATS/ARCHIVES/archives.cgi?ID=6152d1b7066b69ae92c86b2e2a561b716717b1360dd705b0.

Acessado em 2.11.2009.

${ }^{10}$ BULL, Malcolm. States don't really mind their citizens dying (provided they don't all do it at once): they just don't like anyone else to kill them. Disponível em http://www.generationonline.org/p/fpagamben2.htm. Acessado em 5.8.2009.

11 "What are the other merits of Agamben's first ontological decision? I think that they stem from the fact that, armed with his potent ontological determination, Agamben is able to critically engage with the other dimension of his thought (its source of inspiration or ground of comparison): the French poststructuralist experience". NEGRI, Antonio. Op. cit., p. 115.

12 NEGRI, Antonio. Op. cit., p. 110-112. 
com a figura da Itália renascentista, consoante CATHERINE MILls ${ }^{13}$. Aliás, NEGRI qualifica Agamben como o mais determinado representante da segunda geração do pósestruturalismo 14: “Agamben is anything but a 'weak' postmodernist. His concern will be to continually dissolve the ambiguity of the phenomenological reference of poststructuralist thought and bring it back to a new problematic and constructive tableau: that of deconstruction, desire and politics".

Sua produção ${ }^{15}$ centra-se nas relações entre filosofia, estética ${ }^{16}$, religião, política, ontologia, direito e $\operatorname{arte}^{17}$ - de forma geral, poderíamos dizer que Agamben dedica toda sua análise filosófica, filológica, histórica e estética a profanar o sagrado, ou melhor, a procurar devolver à comunidade humana aquilo que historicamente foi subtraído ao uso comum por meio da sacralização ${ }^{18}$-, passando a se dedicar principalmente à filosofia política a partir da década de 1990, de maneira especial às discussões sobre o poder visando ao escrutínio do homo sacer.

Refletindo acerca do capitalismo, das revoluções tecnológicas modernas e da lógica da segurança nas sociedades contemporâneas, Agamben parece assumir como tarefa primordial o alargamento do trabalho de Foucault, andando, portanto, por diversos campos do saber. Nada obstante, Agamben também sofreu palpáveis influências de Walter Benjamin $^{19}$, Friedrich Nietzsche ${ }^{20}$, Martin Heidegger ${ }^{21}$ e Carl Schmitt ${ }^{22}$, entre outros ${ }^{23}$.

\footnotetext{
${ }^{13}$ MILLS, Catherine. The philosophy of Agamben. Montreal and Kingston: McGill-Queen's University Press, 2008, p. 1.

${ }^{14}$ NEGRI, Antonio. Op. cit., p. 116.

${ }^{15}$ Ao ser questionado sobre seu vasto campo de conhecimento, Agamben reflete que "... filosofia, politica, filologia, literatura, teologia, direito não representam disciplinas e territórios separados", para concluir que sua sabedoria "... trata-se do que, há um tempo atrás, era o mínimo esperado de uma pessoa culta - este a quem Nietzsche chamava 'bom europeu'". In: A Política da profanação. Entrevista concedida à Folha de São Paulo em 18.9.2005. Disponível em http://www.geocities.com/vladimirsafatle/vladi081.htm?200722. Acessado em 22.10.2007.

${ }^{16}$ Para uma análise do estado de exceção em sua relação com a arte, notadamente o palco do teatro, vide: FORMIS, Barbara. Dismantling theatricality: aesthetics of bare life. In: CLEMENS, Justin; HERON, Nicholas, MURRAY, Alex (ed.). The work of Giorgio Agamben: law, literature, life. Edinburg University Press, 2008, p. 181-192.

17 "Assim, a filosofia de Agamben se desenvolve de um modo no qual ontologia, política e poesia se encontram tramadas pela estratégia do filósofo. Diz ele que não se pode falar em retorno às condições perdidas na história, mas que somente nos é possível entrever em meio às luzes do presente o escuro que lhe é inerente, uma origem que não está fora da história, mas que garante um olhar não saudosista para o passado e um mirar o futuro sem esperanças outras que não a própria capacidade de repensar o presente". In: SCRAMIM, Susana; HONESKO, Vinícius Nicastro. In: AGAMBEN, Giorgio. O que é contemporâneo? E outros ensaios. Tradução Vinícius Nicastro Honesko. Chapecó: Argos, 2009, p. 21.

${ }^{18}$ Cf. Selvino José ASSMANN. In: AGAMBEN, Giorgio. Profanações. Tradução Selvino José Assmann. São Paulo: Boitempo, 2007, p. 10.

${ }^{19}$ Agamben foi responsável pela edição e tradução italianas das Obras de Benjamin.
} 
Quanto ao método ${ }^{24}$, Agamben reconhece que sua análise não é sociológica e que trabalha com paradigmas ${ }^{2526}$. Com efeito, em Intervista a Giorgio Agamben: dalla teologia política alla teologia-economica, Agamben declina que "Io vedo il mio lavoro senz'altro vicino a quello di Foucault. Nelle mie due ultime ricerche sullo 'stato d'eccezione' e sulla 'teologia economica', ho cercato di applicare lo stesso metodo genealogico e paradigmatico che praticava Foucault",27.

Em outra entrevista, desta feita no Brasil, o próprio Agamben qualifica seu método:

20 “Oh, Nietzsche war auch für mich wichtig. Aber ein wenig halte ich es mit Benjamin, der gesagt hat, die Ewige Wiederkehr, das sei wie die Strafe des Nachsitzens, der Strafarbeit in der Schule, wenn man tausend Mal den selben Satz abschreiben muss". In: AGAMBEN, Giorgio. Ein gespräch mit Giorgio Agamben Das leben, ein kunstwerk ohne autor: der Ausnahmezustand, die verwaltung der unordnung und das private leben. Disponível em www.suddeutschezeitung.com, edição de 6.4.2004. Versão em inglês disponível em German Law Journal, n. 5 (1 May 2004) - special edition. Disponível em http://www.germanlawjournal.com/article.php?id=437. Acessado em 22.10.2007.

${ }^{21}$ No entendimento de ANTONIO NEGRI, Agamben, com enorme coragem, criou uma espécie de revolução copérnica à figura do ser construída por Heidegger: "Heidegger's ontological realism (his materialism?) was, in fact, adopted as the inevitable horizon of the experience of life, of knowing and doing. Agamben separates out experience and language from the morass in which Heidegger has placed them, as if smeared across the horizon of being, and redefines them as possibility". Op. cit., p. 111.

${ }^{22}$ Segundo Agamben, "O encontro com Carl Schmitt se deu, por outro lado, relativamente tarde, e teve um caráter totalmente distinto. Era evidente (creio que é evidente para qualquer um que não seja estúpido nem tenha má-fé, ou, como acontece freqüentemente, as duas coisas juntas) que, se queria trabalhar com o direito e sobre a politica, era com ele que eu deveria medir-me. Como com um inimigo, antes de tudo - mas a antinomia amigo-inimigo era precisamente uma das teses schmittianas que eu queria pôr em questão". In: Entrevista com Giorgio Agamben. Revista do Departamento de Psicologia, UFF, v. 18, n. 1, janeiro/junho 2006. Disponível em http://www.scielo.br/scielo.php?pid=S0104-80232006000100011\&script=sci_arttext. Acessado em 18.11.2009.

23 "As the outline of the chapters suggests, three figures in Western thought have a recurring and fundamental influence on Agamben's thought: Aristotle, Martin Heidegger and Walter Benjamin. This is not to suggest that they are the only important figures in his work; they are not. One could name alongside these figures, philosophers such as Kant, Hegel, Nietzsche, Arendt, the art historian Aby Warburg, Italian literary figures and poets such as Dante and Caproni, and many more besides". MILLS, Catherine. Op. cit., p. 3.

${ }^{24}$ Para uma completa análise do método arqueológico e paradigmático agambeniano, vide Signatura rerum: sul método, sem tradução ao português. A versão em inglês foi traduzida por Luca D'Isanto e Kevin Attell como The signature of all things: on method.

${ }^{25} \mathrm{O}$ próprio Agamben declara que "Aber ich bin kein Historiker. Ich arbeite mit Paradigmen. Ein Paradigma ist so etwas wie ein Beispiel, ein Exempel, ein historisch einmaliges Phänomen". In: AGAMBEN, Giorgio. Ein gespräch mit Giorgio Agamben - Das leben, ein kunstwerk ohne autor: der Ausnahmezustand, die verwaltung der unordnung und das private leben. Disponível em www.suddeutschezeitung.com, edição de 6.4.2004. Versão em inglês disponível em German Law Journal, n. 5 (1 May 2004) - special edition. Disponível em http://www.germanlawjournal.com/article.php?id=437. Acessado em 22.10.2007.

${ }^{26}$ Em palestra proferida em 2002 sob o título What is a paradigm?, que deu subsídios ao primeiro capítulo de Signatura rerum: sul metodo, Agamben analisa conceitos como paradigma e exemplo, inclusive na doutrina de Foucault, Thomas Kuhn e Victor Goldschimit. In: What is a paradigm? European Graduate School, August 2002. Disponível em http://www.egs.edu/faculty/agamben/agamben-what-is-a-paradigm-2002.html. Acessado em 20.9.2007.

${ }^{27}$ Anno 1, n. 4, 2004. Disponível em http://rivista.ssef.it/site.php?page=\&edition=2004-04-01. Acessado em 13.6.2009. 
"Meu método é arqueológico e paradigmático num sentido muito próximo ao de Foucault, mas não completamente coincidente com ele. Trata-se, diante das dicotomias que estruturam nossa cultura, de ir além das exceções que as têm produzido, porém não para encontrar um estado cronologicamente originário, mas, ao contrário, para poder compreender a situação na qual nos encontramos. A arqueologia é, nesse sentido, a única via de acesso ao presente. Porém, superar a lógica binária significa, sobretudo, ser capaz de transformar cada vez as dicotomias em bipolaridades, as oposições substanciais num campo de forças percorrido por tensões polares que estão presentes em cada um dos pontos sem que exista alguma possibilidade de traçar linhas claras de demarcação. Lógica do campo contra lógica da substância. Significa, entre outras coisas, que entre A e A se dá um terceiro elemento que não pode ser, entretanto, um novo elemento homogêneo e similar aos anteriores: ele não é outra coisa que a neutralização e a transformação dos dois primeiros. Significa, enfim, trabalhar por paradigmas, neutralizando a falsa dicotomia entre universal e particular. Um paradigma (o termo em grego quer dizer simplesmente exemplo) é um fenômeno particular que, enquanto tal, vale por todos os casos do mesmo gênero e adquire assim a capacidade de construir um conjunto problemático mais vasto., 28

Já quanto ao estilo, CATHERINE MiLLS, na introdução de sua obra The philosophy of Agamben, expressa que ele é justamente uma das grandes fontes de complexidade da obra do filósofo. Segundo a autora:

"In contrast to the digressions and convolutions to which many have become accustomed through reading figures such as Martin Heidegger or, more recently, Jacques Derrida and his deconstructive followers, Agamben`s style is compact to the point of ellipsis. Most of his books are short - often fewer than 150 pages - but this does not make them easy reading. Instead, highly compacted arguments and insights are presented without explication but with a sharp elegance that provokes as much as it compels. Additionally, and more

${ }^{28}$ In: Entrevista com Giorgio Agamben. Revista do Departamento de Psicologia, UFF, v. 18, n. 1, janeiro/junho 2006. Disponível em http://www.scielo.br/scielo.php?pid=S010480232006000100011\&script=sci_arttext. Acessado em 18.11.2009. 
importantly, over the past several decades Agamben has used various forms within ostensibly philosophical texts in what is ultimately a complex exercise in pushing philosophy to its limits. His arguments and thoughts are developed through fragments, interpolated 'thresholds' and crystalline essays that leave little room for the extensive and patient work of setting out propositions, drawing conclusions and pre-emptively rebutting counter-claims that characterizes much philosophy." 29

De fato, tendemos a concordar que o âmago do pensamento de Agamben não parece, em geral, sistemático e progressivo, forçando o leitor a buscar explicações em outros textos de sua obra que, vez ou outra, podem parecer até mesmo contraditórios. Não há, em nosso entendimento, uma trajetória sistemática observável, mas tão somente um fio mestre condutor que, não ocasionalmente, perde o seu sentido, porquanto é enfrentado de maneiras distintas em textos interconectados. Não é raro que o leitor perca a continuidade de seu trabalho, como comenta LELAND DE LA DURANTAYE ${ }^{30}$. Disso se segue, como não poderia deixar de ser, um caráter enigmático em suas assertivas.

Talvez isso se dê porque, de acordo com Rossano PECORARO, tratamos de um "pensamento que ainda está se desdobrando, construindo, consolidando; que, certamente, possui os seus alicerces, as suas perspectivas já suficientemente definidas, mas que não deixa de ser algo a nós tão próximo e, portanto, bastante difícil de definir. O que acabo de dizer não é nenhuma novidade para os cultores de coisas filosóficas com um mínimo de rigor e honestidade intelectual. Menos óbvio, creio eu, é acenar a uma outra dificuldade, ou seja, a escassez de sólidos comentários sobre a sua obra..."31. Com efeito, a escassez de dados e comportamentos do filósofo italiano enquanto ainda estudante - e até mesmo em sua carreira como professor e conferencista - talvez se dê justamente porque tratamos de um pensador em contínuo fervor.

Para DOMINICK LACAPRA "In Agamben, moreover, a sustained intricacy of formulation and an insistently paratactic or 'poetic' style in philosophy make it both

${ }^{29}$ MILLS, Catherine. Op. cit., p. 2.

${ }^{30}$ DURANTAYE, Leland de la. Op. cit., p. xix.

${ }^{31}$ PECORARO, Rossano. In: Compreender a atualidade através de Agamben. Entrevista concedida em 4.3.2009. Disponível em http://www.ihu.unisinos.br/index.php?option=com_noticias\&Itemid=18\&task $=$ detalhe\&id=20360. Acessado em 15.7.2009. 
difficult to understand him in a way that enables critical exchange and possible for a sympathetic (or perhaps extremely generous) reader (or overwriter) to gloss questionable passages in a quasi-theological manner that always displaces attention to other, less dubious passages, even if they are found in another work",32.

De fato, esse exercício interpretativo demanda do leitor o auxílio de opiniões e comentários de obras de terceiros que, acertadamente ou não, fatalmente influenciarão a formação de sua própria convicção. Assim, há o evidente risco de a conclusão final do intérprete escapar da intenção ou do agir comunicativo original do autor, uma vez que a compreensão poderá restar determinada por reflexões de outrem.

Quanto ao conjunto de sua obra, Agamben caminha por diversos campos como “... Biblical textual criticism, cinema studies, medieval literature, legal philosophy (ancient and modern), the philosophy of language, journalistic comentary on Italian and world politics, theories of friendship, art and aesthetics, ontology, poetics, holocaust literature, the histoty of philosophy, as well as speculative writing which gestures towards a creative practice”, consoante Justin Clemens, Nicholas Heron e AleX MurRay ${ }^{33}$.

No livro L'uomo senza contenuto, publicado na Itália em 1970 e sem tradução ao português, Agamben diagnostica a essência niilista da arte (estética) na era moderna por meio de fraturas e cisões que atravessam a figura do espectador (falta de interesse) e do artista (interesse perigoso). Agamben busca o retorno a uma concepção originária da arte que recupere uma distinção grega antiga entre poiésis e práxis e, ainda, devolva à primeira sua relação com a verdade ao invés da vontade ${ }^{34}$.

${ }^{32}$ LACAPRA, Dominick. Approaching limit events: siting Agamben. In: CALARCO, Matthew; DECAROLI, Steven (ed.). Giorgio Agamben: sovereignty and life. Stanford, California: Stanford University Press, 2007, p. 133.

${ }^{33}$ In: The enigma of Giorgio Agamben. In: CLEMENS, Justin; HERON, Nicholas; MURRAY, Alex (ed.). The work of Giorgio Agamben: law, literature, life. Edinburg University Press, 2008, p. 2.

${ }^{34}$ Para Sueli CAVENDISH, Agamben não se limita nessa obra a “.... desvelar a essência alienada da obra de arte; ele empreende uma indagação sustentada e constante, sob vários prismas, a respeito dos destinos da arte em nosso tempo, vendo este tempo como um momento privilegiado para que a arte, assumindo uma verdadeira crítica, aponte uma saída do que chama o pântano da estética e da técnica, em direção à restauração do status poético do ser humano à sua dimensão originária". In: Poiésis, negatividade e a condição moderna da arte em Giorgio Agamben. Disponível em http://paginas.terra.com.br/arte/dubitoergosum/a41.htm. Acessado em 22.10.2007. 
Muito embora os livros subsequentes Stanze: la parola e il fantasma nella cultura occidentale (Estâncias: a palavra e o fantasma na cultura ocidental ${ }^{35}$ ), publicado em 1977, e Infanzia e storia: distruzione dell'esperienza e origine della storia (Infância e história: destruição da experiência e origem da história), de 1978, auxiliem o leitor a compreender o pensamento crítico do autor, é com a tradução de Il linguaggio e la morte: un seminario sul luogo della negatività (1982), traduzido ao português sob o título $A$ linguagem e a morte: um seminário sobre o lugar da negatividade, que Agamben torna-se conhecido internacionalmente, segundo o prefácio do livro Giorgio Agamben: Sovereignty $\&$ Life, editado por Matthew Calarco e Steven DeCARoli.

Em A linguagem e a morte, Agamben, em suas próprias palavras, trouxe idéias “discutidas do inverno de 1979 ao verão de 1980, ao longo de um seminário do qual participaram Massimo De Carolis, Giuseppe Russo, Antonella Moscati e Noemi Plastino" 36 acerca do modo como a linguagem é pensada como faculdade ou capacidade do ser humano na política ocidental, bem como a tendência moderna de o pensamento metafísico balizar o ser e a linguagem na negatividade ${ }^{37}$.

Ou seja, ele visualiza o local originário da estrutura da negatividade no pensamento metafísico, levantando discussões quanto ao conteúdo do pensamento de Heidegger quanto à introdução da negatividade no ser por meio do Da ("a negatividade provém, ao Dasein, de seu próprio $\mathrm{Da}^{\natural 38}$ ), e de Hegel (das Diese nehmen) quanto à pobreza das palavras, não olvidando a relação ontológica entre linguagem, experiência e morte. No entendimento de Justin CLEMENS, “... given that the two greatest modern attempts to elaborate the logic of

\footnotetext{
${ }^{35}$ Em introdução à obra, Sabrina SEDLMAYER comenta que “... No decorrer da leitura apreendemos vários sentidos que o título desta obra, Stanze, nos oferece: mais que estrofe de uma canção, Agamben reclama aqui a definição da poesia como abrigo, cômodo que é capaz de guardar, pela falta e impossibilidade que constitui a palavra, a fugaz alegria do amor. A referência a Heidegger é nítida. Mas outros escritores saturninos que discorreram sobre fantasmas de Eros na modernidade, como Freud, Marx, Baudelaire, Warburg e Benjamin, além da semiologia e da linguística saussuriana vêm auxiliar a compreensão do círculo hermenêutico que se estabelece entre desejo, fantasma e palavra”. In: AGAMBEN, Giorgio. Estâncias: a palavra e o fantasma na cultura ocidental. Tradução de Selvino José Assmann. Belo Horizonte: Editora UFMG, 2007.

${ }^{36}$ AGAMBEN, GIORGIO. A linguagem e a morte: um seminário sobre o lugar da negatividade. Tradução Henrique Burigo. Belo Horizonte: Editora UFMG, 2006, Nota do Autor.

37 "Some of the most intractable problems that Agamben addresses in his work derive from his engagement with the history of metaphysics in Western philosophy, and particularly the tendency that he diagnoses in metaphysical thought to presuppose and posit a foundation for being and language in negativity". MILLS, Catherine. Op. cit., p. 9.

${ }^{38}$ AGAMBEN, Giorgio. A linguagem e a morte: um seminário sobre o lugar da negatividade. Tradução Henrique Burigo. Belo Horizonte: Editora UFMG, 2006, p. 18.
} 
negative are those of Hegel and Heidegger, it is precisely to them that Agamben turns to illuminate its ruses" ${ }^{, 39}$.

Assim como o animal não pode ter a experiência da morte porque não concebe a morte - ele não morre, mas cessa de viver -, o animal não pode ter a experiência da linguagem. $\mathrm{O}$ homem, apropriando-se da mundanidade por meio da linguagem ${ }^{40}$, é o único animal que possui a faculdade da linguagem e a faculdade da morte: "Se a linguagem fosse imediatamente a voz do homem, como o zurro é a voz do asno e o rechino é a voz da cigarra, o homem não poderia ser-o-aí nem aprender o Isto, logo, não poderia jamais ter experiência do ter-lugar na linguagem e da abertura do ser" ${ }^{\prime 1}$. Para CATHERINE MILLS:

"While the contemporary collapse of metaphysics into ethics that the grounding of humanity in negativity generates is increasingly evident as nihilism, contemporary thought has yet to escape from or go beyond this condition. The task that Agamben sets for contemporary thought, then, is to understand and ultimately redefine the nihilism that increasingly appears at the heart of humanity`s ungroundedness." 42

Aliás, essa questão é anteriormente trazida à tona em Infanzia e storia, obra na qual o autor centraliza suas considerações no significado de eu falo e eu posso falar, bem como na significação da própria linguagem e da constituição do ser emissor enquanto ente da linguagem. Pronomes como eu e advérbios como aqui ou agora, assim como o $D a$ e o Diese - shifters, ou indicadores de enunciação, cuja função é articular a passagem da língua (código) à fala (mensagem) -, não indicam ou se referem a objetos fora de si, não ganham significado por meio de uma relação com um objeto fora da linguagem, mas tornam evidente o fenômeno da própria linguagem ${ }^{43}$.

${ }^{39}$ CLEMENS, Justin. The role of the shifter and the problem of reference in Giorgio Agamben. In: CLEMENS, Justin; HERON, Nicholas, MURRAY, Alex (ed.). The work of Giorgio Agamben: law, literature, life. Edinburg University Press, 2008, p. 44.

${ }^{40}$ Cf. Giorgio AGAMBEN. Means without end: notes on politics. Tradução Vincenzo Binetti e Cesare Casarino. Minneapólis: University of Minnesota Press, 2000, p. 91.

${ }^{41}$ AGAMBEN, Giorgio. A linguagem e a morte: um seminário sobre o lugar da negatividade. Tradução Henrique Burigo. Belo Horizonte: Editora UFMG, 2006, p. 115.

42 MILLS, Catherine. Op. cit., p. 12.

43 "O abrir-se da dimensão ontológica (o ser, o mundo) corresponde ao puro ter-lugar da linguagem como evento originário, enquanto a dimensão ôntica (os entes, as coisas) corresponde àquilo que, nesta abertura, é dito e significado. A transcendência do ser em relação ao ente, do mundo em relação à coisa, é, primeiramente transcendência do evento da linguagem em relação à fala. E os shifters, as pequenas palavras 
Agamben, nesse e em outros textos, enfatiza a coisa ou a idéia ${ }^{44}$ de linguagem, traçando a articulação entre a phoné animal e o significado, bem como linguagem e discurso na articulação ontológica, e não cronológica, da infância ${ }^{45}$, chamando atenção para a possibilidade de uma linguagem pura - num paralelo à violência pura de Benjamin que comunicaria nada além de sua própria comunicabilidade: o seu experimentum linguae $^{46}$ da infância.

Em última instância, Agamben visa superar a metafísica com vistas a um novo conceito de pura experiência, não como sistema de significação ou meio de comunicação, mas algo anterior à subjetividade e a uma alegada realidade psicológica, uma nova filosofia ${ }^{47}$.

Na obra Idea della prosa (1985), traduzida ao português em 1999, Agamben revive a relação ontológica entre filosofia e poesia, bem como linguagem enquanto figura da

isto, aqui, eu, agora, por meio das quais, na Fenomenologia do Espírito, a certeza sensível acredita poder captar imediatamente a própria Meinung, já estão sempre presas nesta transcendência, indicam desde sempre o lugar da linguagem". In: AGAMBEN, Giorgio. A linguagem e a morte: um seminário sobre o lugar da negatividade. Tradução Henrique Burigo. Belo Horizonte: Editora UFMG, 2006, p. 44.

${ }^{44}$ Vide AGAMBEN, Giorgio. The idea of language: In: HAMACHER, Werner; WELBERY, David (ed.). Potentialities. Stanford: Stanford University Press, 1999, p. 39-47.

45 "But instead of simply referencing the neonatal condition as a developmental stage, Agamben's notion of infancy appropriates a now-obsolete meaning of the term, which derives from the Latin 'infans', in which 'fans' is the present participle of 'fari', meaning 'to speak'. Etymologically, then, the 'in-fancy' means to be unable or unwilling to speak, to be silent or speechless. (...) Infancy conceptualizes an experience of being in language without speech, not in a temporal or developmental sense of preceding the acquisition of language in childhood, but as an ontological condition of speaking that continues to reside in any appropriation of language". MILLS, Catherine. Op. cit., p. 25.

46 "O homem não sabe simplesmente, nem simplesmente fala, não é homo sapiens ou homo loquens, mas homo sapiens loquendi, homem que sabe e pode falar (e, portanto, também não falar), e este entrelaçamento constitui o modo com o qual o Ocidente compreendeu a si mesmo e que pôs como fundamento do seu saber e de suas técnicas. A violência sem precedentes do poder humano tem a sua raiz última nesta estrutura da linguagem. Neste sentido, aquilo de que no experimentum linguae se tem experiência não é simplesmente uma impossibilidade de dizer: trata-se, antes, de uma impossibilidade de falar a partir de uma língua, isto é, de uma experiência - através da moradia infantil na diferença entre língua e discurso - da própria faculdade ou potência de falar. Colocar o problema do transcendental significa, em última análise, perguntar o que quer dizer 'possuir uma faculdade', qual é a gramática do verbo 'poder'. E a única resposta possível é uma experiência da linguagem”. AGAMBEN, Giorgio. Infância e história: destruição da experiência e origem da história. Tradução Henrique Burigo. Belo Horizonte: Editora UFMG, 2005, p. 15.

47 'In the extraordinary essay 'Infancy and History: An Essay in the Destruction of Experience', Agamben begins his concerted reflection on the concept of experience in the modern world - reflected in the loss of the capacities of the storyteller - and places his own efforts within the programme for a 'coming philosophy' that Benjamin outlines elsewhere. In outlining a programme for a future philosophy, Benjamin proposes that this must be centrally concerned with the interrelation of three concepts, namely epistemology, metaphisics and religion, particularly in relation to the unfinished philosophy of Immanuel Kant. 'Unfinished' because, in Benjamin`s view, Kant was unable to adequately address the relation between experience and knowledge. In developing a 'prolegomena to a future metaphysics', then, the coming philosophy must develop not only a new conception of knowledge but also a new concept of experience”. MILLS, Catherine. Op. cit, p. 22. 
punição. Para AleXAnder García DütTMann, "Agamben does not want to keep meaning apart from poetic sound and rhytim. Rather, for him, the question of the relationship between philosophy and poetry becomes the question of a language or a prose that no longer lets itself be determined by the difference inscribed in this relationship" ${ }^{\text {" }}$.

Entretanto, segundo Matthew Calarco e Steven DeCaroli, é somente com a publicação de La comunità che viene (1990), sem tradução ao português, que Agamben teria despertado o interesse escolar por seus textos:

"Over the next decade, as more of Agamben`s works found their way into the English-speaking context, it became increasingly evident that Agamben`s influence on the current generation of scholarship would be a lasting one. Given the growing enthusiasm for both Agamben`s writing and the questions his writings raise, the time has come for a broader dialogue."49

Essa mesma opinião é compartilhada por CATHERINE MILLS, para quem "since the translation of his enigmatic work, The Coming Community, in 1993, English publication of his work has occurred at an ever-increasing rate". Para essa autora, as densas reflexões filosóficas de Agamben sobre a problemática da soberania e da biopolítica transformaram o próprio discurso crítico contemporâneo, de maneira que termos como exceção e vida não podem ser utilizados atualmente sem referência direta a Agamben.

Muito embora ela reconheça a alta complexidade e a dificuldade do trabalho de Agamben que obscurecem a importância filosófica do pensamento analisado, ela concorda que o italiano contribuiu igualmente para reabrir questões da filosofia antropológica ao externar interessantes distinções entre a animalidade e a humanidade ${ }^{50}$, tema central na obra L'aperto: l'uomo e l'animale ${ }^{5 l}$, ainda sem tradução ao português, interpretada por DINESH WADIWEL ${ }^{52}$.

48 DÜTTMANN, Alexander García. Integral actuality: on Giorgio Agamben's Idea of Prose. In: CLEMENS, Justin; HERON, Nicholas, MURRAY, Alex (ed.). The work of Giorgio Agamben: law, literature, life. Edinburg University Press, 2008, p. 28.

${ }^{49}$ CALARCO, Matthew; DECAROLI, Steven (ed.). Op. cit., Prefácio.

${ }^{50}$ MILLS, Catherine. Op. cit., p. 1.

${ }^{51}$ AGAMBEN, Giorgio. L'aperto, l'uomo, l'animale. Torino: Bolatti Boringuieri, 2002.

${ }^{52}$ WADIWEL, Dinesh. Animal by any other name? Patterson and Agamben discuss animal (and human) life. Borderlands e-journal, v. 3(1)

http://www.borderlands.net.au/vol3no1_2004/wadiwel_animal.htm.

Disponível

em 
Na apresentação ao livro Profanazioni, obra publicada em 2004 e traduzida ao português em 2007 que reúne uma dezena de textos escritos em momentos anteriores e posteriores a outros livros do autor, SELVINO J. ASSMANN qualifica Agamben como um dos mais importantes e mais lidos pensadores europeus da atualidade, discorrendo que:

"Em um mundo onde tudo parece ter-se tornado necessário e inevitável, sagrado, Agamben procura resistir, des-criar o que existe, tentando ser mais forte do que o que está ai, como o faz o escriturário Bartleby de Melville (“preferia não!”). Isso equivale a ir em busca da infância, ou seja, de nossa capacidade de jogar e de amar, a saber, de viver na intimidade de um ser estranho, não para fazê-lo conhecido, e sim para estar ao lado dele sem medo de ficar entre o dizível e o indizível; equivale a perseguir sinais e frestas de contingência, de 'absoluta contingência', ou seja, de subjetividade, de liberdade humana, de cesuras entre um poder-ser e um poder-não-ser. Insistase: um mundo em que tudo é necessário e nada é possível é um mundo sem sujeito, um mundo sem liberdade, sem possibilidade de criação." 53

Para Olgária Matos, Profanações trata justamente dos interstícios da cultura capitalista, na qual se expressa a ultrapassagem da economia de mercado pela sociedade de mercado, a saber, pela universalização do fenômeno do fetichismo em sua estrutura desrealizante ${ }^{54}$.

Merece ser citado, ainda, sem prejuízo dos demais textos que serão apontados no decorrer desta dissertação, o recente $O$ que é contemporâneo? E outros ensaios, que, na verdade, é a reunião de três textos ${ }^{55}$ em que o autor, segundo SUSANA SCRAMIM e VINÍCIUS HONESKO, descreve todo o procedimento pelo qual oikonomía passa a ser traduzida para o ríspido latim dos padres da alta Idade Média como dispositio, e, a partir de Aristóteles,

\footnotetext{
${ }^{53}$ In: AGAMBEN, Giorgio. Profanações. Tradução de Selvino José Assmann. São Paulo: Boitempo, 2007, p. 7.

${ }^{54}$ Cf. Olgária MATOS. In: AGAMBEN, Giorgio. Profanações. Tradução Selvino José Assmann. São Paulo: Boitempo, 2007.

${ }^{55}$ Che cos'è Il contemporaneio?, Che cos'è um dispositivo? e L'amico.
} 
propõe uma leitura que assinala de modo premente o estatuto ontológico e ao mesmo tempo político da amizade ${ }^{56}$.

Em que pese a importância das obras acima delineadas para compreensão da filosofia do autor, é na trilogia ${ }^{57}$ com respeito ao homo sacer que Agamben, em nosso entendimento, ganha especial atenção na filosofia jurídica, porquanto renova o vínculo entre violência e direito, descrevendo os mecanismos de inclusão e exclusão - na verdade, exclusão inclusiva (esclusione inclusiva) - do indivíduo subjacentes à teoria da soberania: tema que bem se adequou ao despertar do 11 de setembro, das guerras do Afeganistão e Iraque e dos estados de exceção de Abu Ghraib e Guantanamo Bay, entre tantos outros exemplos.

É na suspensão da lei que se relacionam vivente e norma jurídica, factum e ius, num contínuo estado de exceção: "That the state of exception has become the rule, that we live in the age of the suspension of the law, is what the work of Agamben constantly stresses", consoante BRUNO GULLI ${ }^{58}$.

Numa entrevista conferida para o Süddeutsche Zeitung ${ }^{59}$, de 6 de março de 2004, Agamben declara que seu livro Stato di Eccezione “... gehört zu einer Reihe von genealogischen Essays, die an „Homo Sacer” anschließen und eine Tetralogie bilden sollen. Von der Sache her geht es um zwei Punkte. Der erste ist historischer Art: Der Ausnahme- oder Dringlichkeitszustand ist heute zum Paradigma des Regierens geworden.

${ }^{56}$ Cf. Susana SCRAMIM e Vinícius Nicastro HONESKO, para quem “... A partir desse levantamento, Agamben propõe uma chave de leitura do termo dispositivo em Michel Foucault... para ampliá-lo e elevá-lo à categoria fundamental para a compreensão do mecanismo político contemporâneo... Como máquina que no contato com os viventes produz sujeitos, o dispositivo é também uma máquina de governo (os sujeitos, livres, são sempre sujeitados a um poder). No entanto diferentemente do que acontecia com os dispositivos ditos tradicionais (a confissão, a prisão, as escolas etc.), isto é, um ciclo completo de subjetivação (um novo sujeito que se constitui a partir da negação de um velho), nos dispositivos hodiernos (a internet, os telefones celulares, a televisão, as câmeras de monitoramento urbano etc.), não é mais possível constatar a produção de um sujeito real, mas uma reciproca indiferenciação entre subjetivação e dessubjetivação, da qual não surge um sujeito espectral." In: AGAMBEN, Giorgio. O que é contemporâneo? e outros ensaios. Tradução de Vinícius Nicastro Honesko. Chapecó: Argos, 2009, p. 12.

${ }^{57}$ Muito embora o conjunto da obra seja composto, até o momento, por Homo Sacer I, II.1, II.2, II. 3 e III.

${ }^{58}$ GULLI, Bruno. The ontology and politics of exception: reflections on the work of Giorgio Agamben. In: CALARCO, Matthew; DECAROLI, Steven (ed.). Giorgio Agamben: sovereignty and life. Stanford, California: Stanford University Press, 2007, p. 239.

${ }^{59}$ AGAMBEN, Giorgio. Ein gespräch mit Giorgio Agamben - Das leben, ein kunstwerk ohne autor: der Ausnahmezustand, die verwaltung der unordnung und das private leben. Disponível em www.suddeutschezeitung.com, edição de 6.4.2004. Versão em inglês disponível em German Law Journal n. 5 (1 May 2004) - special edition. Disponível em http://www.germanlawjournal.com/article.php?id=437. Acessado em 22.10.2007. 
Ursprünglich etwas Außergewöhnliches, eben die Ausnahme, die nur für eine begrenzte Zeit Bestand haben sollte, ist er aufgrund einer historischen Transformation zur normalen Form des Regierens geworden. Ich wollte zeigen, welche Bedeutung dieser Wandel für die Verfassung der Demokratien hat, in denen wir leben. Der zweite ist philosophischer Natur und betrifft das seltsame Verhältnis von Gesetz und Gesetzlosigkeit, Gesetz und Anomie. Der Ausnahmezustand stellt eine geheime, aber fundamentale Beziehung zwischen dem Gesetz und der Abwesenheit des Gesetzes her. Er ist ein void, eine Leerstelle, aber diese Leerstelle ist konstitutiv für das juridische System".

Outrossim, parece-nos que uma das maiores razões para que o trabalho de Agamben seja inquietante é sua contribuição ao debate contemporâneo sobre a lógica da segurança ${ }^{60}$. Para Agamben, a concepção de democracia hoje existente ainda está dominada pelo paradigma do Estado de Direito, ou seja, pela idéia de que podemos estabelecer um quadro constitucional e normativo a partir do qual uma sociedade justa advém possível. "Mas minhas pesquisas me mostraram que o problema fundamental não diz respeito à Constituição ou à lei; diz respeito ao governo" ${ }^{„ 61}$. Isto é, o tema central do conjunto da obra será uma operação da política que, sob a roupagem da prevenção da desordem - ou mesmo preservação da ordem -, trabalha secretamente para a produção de emergências ${ }^{62}$ : “A segurança como paradigma de governo não nasce para instaurar a ordem, mas para governar a desordem"63. Uma desordem que traz à evidência a estrutura do a-bando-no que rege a vida humana e a nuda vita e ela inerente.

É dizer, sob o mote da segurança da ordem constitucional e/ou do Estado e/ou do homem e/ou do próprio cidadão ou, ainda, da relação entre eles, o governo transforma o

\footnotetext{
60 "Today we face extreme and most dangerous developments in the thought of security. In the course of a gradual neutralization of politics and the progressive surrender of traditional tasks of the state, security becomes the basic principle of the state activity. What used to be one among several definitive measures of public administration until the first half of the twentieth century, now becomes the sole criterium of political legitimation". AGAMBEN, Giorgio. On security and terror. In: Frankfurter Allgemeine Zeitung (20.9.2001). $\quad$ Tradução $\quad$ Soenke $\quad$ Zehle. $\quad$ Disponível em http://fazarchiv.faz.net/webcgi?START=A20\&DOKM=775258_FAZ_0\&WID-69343-5800873-11505_4. Acessado em 22.10.2007.

${ }^{61}$ Cf. Giorgio AGAMBEN. In: Política da Profanação. Entrevista concedida à Folha de São Paulo em 18.9.2005. Disponível em http://www.geocities.com/vladimirsafatle/vladi081.htm?200722. Acessado em 22.10.2007.

${ }^{62}$ Cf. Giorgio AGAMBEN. In: On security and terror. In: Frankfurter Allgemeine Zeitung (20.9.2001). Disponível em http://fazarchiv.faz.net/webcgi?START=A20\&DOKM=775258_FAZ_0\&WID-693435800873-11505_4. Acessado em 22.10.2007.

${ }^{63}$ Cf. Giorgio A AAMBEN. In: Política da Profanação. Entrevista concedida à Folha de São Paulo em 18.9.2005. Disponível em http://www.geocities.com/vladimirsafatle/vladi081.htm?200722. Acessado em 22.10.2007.
} 
que seria o sacrifício temporário (zeitliche) da democracia por meio de uma fictio iuris em contínua técnica de governo. Uma ficção jurídica que, para Agamben, repousa na mesmíssima lógica qualificadora do totalitarismo moderno: “... l’instaurazione, attraverso lo stato di eccezione, di una guerra civile legale, che permette l'eliminazione fisica non solo degli avversari politici, ma di intere categorie di cittadini che per qualche ragione risultino non integrabili nel sistema politico" ${ }^{\circ 4}$.

Quer dizer, o Estado, ou melhor, o governo, na visão agambeniana, não se preocupa com a ordem, mas, cultivando a cultura do medo - o medo derivado de que trata ZYGMUNT BAUMAN enquanto “... estrutura mental estável que pode ser mais bem descrita como o sentimento de ser suscetível ao perigo; uma sensação de insegurança" ${ }^{\text {"65 }}$-, administra a desordem justamente para que sejam eliminados quaisquer adversários políticos que não sejam integráveis ao sistema. Uma vestidura que é hoje o paradigma dominante de governo: o que era uma suspensão temporária da lei se tornou gradualmente uma técnica usual de governo; o extraordinário que se torna padrão.

Abre-se espaço, assim, para o advento de um estado de exceção permanente e muitas vezes voluntário ${ }^{66}$ : um estado de exceção que não é imposto por vias subversivas, golpistas ou revolucionárias, mas que, muito rasteiramente, insere-se no coração da democracia, do Estado de Direito e a fortiori da própria economia. De acordo com GILBERTO BERCOVICI:

"Da garantia do Estado, o estado de exceção passou a ser empregado na garantia da constituição e agora consolida-se o modelo da garantia do capitalismo."

\footnotetext{
${ }^{64}$ AGAMBEN, Giorgio. Stato di eccezione. Turim: Bollati Boringhieri, 2003, p. 11.

${ }^{65}$ BAUMAN, Zygmunt. Medo líquido. Tradução de Carlos Alberto Medeiros. Rio de Janeiro: Jorge Zahar Ed., 2008, p. 9.

${ }^{66}$ Em estudo sobre a violência policial na Cidade de São Paulo, Teresa Pires do Rio CALDEIRA expressa que "a persistência da violência policial e seu crescimento recente foi possível pelo menos em parte por causa do apoio popular. Paradoxalmente, mesmo as camadas trabalhadoras, que são as principais vítimas dessa violência, apóiam algumas de suas formas... Assim sendo, o apoio popular aos abusos da polícia sugere a existência não de uma simples disfunção institucional mas de um padrão cultural muito difundido e incontestado que identifica a ordem e a autoridade ao uso da violência. A deslegitimação dos direitos civis é inerente a esse padrão". In: CALDEIRA, Teresa Pires do Rio. Cidade de muros: crime, segregação e cidadania em São Paulo. Tradução de Frank de Oliveira e Henrique Monteiro. São Paulo: Edusp, 2000, p. 136.

${ }^{67}$ BERCOVICI, Gilberto. Soberania e constituição: para uma crítica do constitucionalismo. São Paulo: Quartier Latin, 2008, p. 46.
} 
Esse espaço demonstra justamente a fragilidade do Estado, porquanto "A state which has security as its sole task and source of legitimacy is a fragile organism; it can always be provoked by terrorism to become itself terroristic" ${ }^{\prime \prime}$. Em outras palavras, "o verdadeiro ponto misterioso da política ocidental não é o Estado, não é a Constituição, não é a soberania, mas o governo. Não o soberano, mas o ministro. Não o legislador, mas o funcionário" ${ }^{69}$ :

“J'ai essayé de montrer dans un livre récent que le mystère central de la politique n'est pas la souveraineté mais le gouvernement, n'est pas Dieu mais l'ange, n'est pas le roi mais le ministre, n'est pas la loi mais la police - ou plus précisément, la double machine gouvernementale qu'ils forment et maintiennent em mouvement."70

Daí a idéia de corrosão dos modelos jurídico-político tradicionais. Agamben, pregando a "decadência" d1 da cultura jurídica, atrai o leitor a refletir, ou melhor, seriamente questionar as áreas mais obscuras do direito e da democracia, isto é, justamente aquelas que supostamente legitimam a violência e a suspensão de direitos em nome da ordem e da segurança.

Inevitável, assim, que Agamben cite por diversas vezes a estratégia do governo estadunidense - principalmente após os ataques de 11 de setembro, mas sem olvidar diversos atos pretéritos de diversos governos -, que, sob o pretexto de aumentar ou solidificar a segurança nacional contra o terrorismo, implanta regras que não raramente desrespeitam direitos e/ou garantias fundamentais, ou seja, implanta uma pax americana às avessas. Assim, não somente o País e o Terceiro Mundo, mas, de maneira especial, as democracias européias e, principalmente, estadunidense, estariam a concretizar uma nova técnica de governo abalizada unicamente na pretensa necessidade, um conceito subjetivo

${ }^{68}$ Cf. Giorgio AGAMBEN. In: On security and terror. In: Frankfurter Allgemeine Zeitung (20.9.2001). $\begin{array}{lllll}\text { Tradução de } & \text { Soenke } & \text { Zehle. } & \text { Disponível } & \mathrm{em}\end{array}$ http://fazarchiv.faz.net/webcgi?START=A20\&DOKM=775258_FAZ_0\&WID-69343-5800873-11505_4. Acessado em 22.10.2007.

${ }^{69}$ AGAMBEN, Giorgio. Política da Profanação. Entrevista concedida à Folha de São Paulo em 18.9.2005. Disponível em http://www.geocities.com/vladimirsafatle/vladi081.htm?200722. Acessado em 22.10.2007.

${ }^{70}$ AGAMBEN, Giorgio. Note liminaire sur le concept de démocratie. In: Démocratie dans quel état? La Fabrique éditions, 2009, p. 12.

${ }^{71}$ AGAMBEN, Giorgio. Estado de exceção. São Paulo: Boitempo, 2004, p. 59. 
esvaziado numa decisão, que, na visão de Agamben, ao contrário de Carl Schmitt, não é justificativa a súbitas medidas arbitrárias, mas ferramenta de um contínuo estado de exceção.

Dessa forma, todo o esforço de Agamben consiste em mostrar que a suspensão democrática da lei não é um fenômeno localizado, mas uma tendência hegemônica da modernidade; um fenômeno planetário. Como saída desse paradigma, Agamben requer a investigação das possibilidades de uma vida humana - uma ética - livre de qualquer poder soberano. Essa vida significaria o fim da separação e oposição das diversas formas de vida tipificadas por Agamben, uma vida que rejeite a tradição humanista em prol de uma política asoberana e ajurídica:

“Até que, todavia, uma política integralmente nova - ou seja, não mais fundada sobre a exceptio da vida nua - não se apresente, toda teoria e toda praxe permanecerão aprisionadas em um beco sem saídas, e o 'belo dia' da vida só obterá cidadania política através do sangue e da morte ou na perfeita insensatez a que a condena a sociedade do espetáculo." 72

TERCIO SAMPAIO FERRAZ JR. parece solidário ao pensamento de uma lógica além da soberania, notadamente à luz da experiência totalitária do século XX, ao debater a política brasileira - mas também mundial - com Miguel Reale Júnior e Jorge Forbes, entre outros:

"No século XX, os exemplos que tivemos com esse sentido são perigosíssimos, assustam, porque imediatamente, o que se propõe além do indivíduo é o Estado, a idéia de uma comunidade soberana. Essa experiência é terrível. Como evitar isso é o nosso desafio."73

É nesse sentido que Agamben preocupa-se em buscar uma conceituação mais precisa da essência humana, partindo da própria revisão dos vínculos que unem soberania, lei, Estado e vida. Assim, como dito acima, inevitável que o binário humano/animal seja

\footnotetext{
72 AGAMBEN, Giorgio. Homo sacer: o poder soberano e a vida nua I. Tradução de Henrique Burigo. Belo Horizonte: Editora UFMG, 2002, p. 19.

${ }^{73}$ FERRAZ JR, Tercio Sampaio. In: FOBES, Jorge; REALE JR, Miguel; FERRAZ JR, Tercio Sampaio (org.). A invenção do futuro: um debate sobre a pós-modernidade e a hipermodernidade. Barueri: Manole, 2005, p. 39.
} 
igualmente alvo do conjunto da obra de Agamben - muito embora ele foque no lado humano desse binário ${ }^{74}$-, até mesmo porque a vida nua do homo sacer será comparada a figuras híbridas entre o homem e o animal, uma criatura humana, como o próprio lobisomem ou o muçulmano.

Em Homo sacer: o poder soberano e a vida nua I, do original Homo sacer: il potere sovrano e la nuda vita, de 1995, Agamben parece demonstrar que a vida não mais pode ser tomada como noção jurídica, médica ou científica, definindo o povo como aquilo que não pode ser incluído no todo de que faz parte, quanto aquilo que não pode pertencer ao conjunto em que, mesmo assim, permanece excluído.

Em Mezzi senza fine: note sulla politica (1996), sem tradução ao português, Agamben investiga, numa série de textos, paradigmas políticos e desde logo anuncia que a política atual atravessa um eclipse, uma vez que “... it has been losing sight of its own ontological status, it has failed to confront the transformations that gradually have emptied out its categories and concepts" ${ }^{\$ 7}$. Embora esse livro não seja formalmente considerado parte do grupo homo sacer, certamente é um elemento indispensável ao conjunto da obra. A bem da verdade, muitos conceitos - até mesmo frases - elaboradas neste livro são reproduzidas em publicações posteriores.

Já O que resta de Auschwitz: o arquivo e a testemunha (ou Homo Sacer III, do original Quel che resta di Auschwitz: l'archivio e il testimone), publicado em 1998, ocupa lugar intermediário e singular, porquanto, ao tratar do testemunho - tema trazido à literatura brasileira, num contexto agambeniano, por ETTORE FINAZZI-AGRÒ ${ }^{76}$ - num espaço onde não há referências básicas de humanidade, o campo de concentração, anuncia

\footnotetext{
74 "Where one might expect a radically post-humanist thinker such as Agamben to challenge the oppositional and reductionist determinations of animal life characteristic of Western metaphysics, he has (in line with the majority of Continental philosophers) remained largely content to occupy the human side of the human/animal binary in order to complicate and rethink the political consequences of essentialist definitions of the human". CALARCO, Matthew. Jamming the Anthropological machine. In: CALARCO, Matthew; DECAROLI, Steven (ed.). Giorgio Agamben: sovereignty and life. Stanford, California: Stanford University Press, 2007, p. 164.

75 AGAMBEN, Giorgio. Means without end: notes on politics. Traducão Vincenzo Binetti e Cesare Casarino. Minneapólis: University of Minnesota Press, 2000, Prefácio.

${ }^{76}$ Ettore FINAZZI-AGRÒ traça um interessante paralelo entre a figura da testemunha no pensamento de Agamben e personagens da literatura brasileira. Vide, a título de exemplo, o texto A voz de quem morre. O indício e a testemunha em "Meu tio Iauraretê". Disponível em http://www.letras.ufmg.br/poslit/08_publicacoes_txt/er_12/er12_ef.pdf. Acessado em 24.5.2009.
} 
uma temática teológico-política que será desenvolvida no livro seguinte Il tempo che resta: un comento alla Lettera ai Romani ${ }^{77}$, de 2000, sem tradução ao português.

JEANNE MARIE Gagnebin insiste nas dificuldades do título desse livro ( $O$ que resta de Auschwitz) porque "À primeira vista, parece que temos em mãos mais um livro sobre Auschwitz, não um livro histórico - desde a primeira página, o autor nos adverte que a questão das 'circunstâncias históricas' já foi devidamente esclarecida pelos historiadores de Shoah - mas um livro sobre as dificuldades do testemunho",78.

Por oportuno, embora $O$ que resta de Auschwitz seja classificado sob a numeração Homo Sacer III, os livros subsequentes - Stato di eccezione, de 2003, traduzido ao português em 2004 como Estado de exceção, Il regno e la gloria: per una genealogia teologica dell'economia e del governo ${ }^{79}$, do início de 2007 , e, ainda, o recente Il sacramento del linguaggio: archeologia del giuramento, ambos sem tradução ao português - trazem respectivamente os números II.1, II.2 e II.3, podendo causar confusão ao leitor.

Mas as teorias de Agamben são muito controvertidas, o que será demonstrado no decorrer desta dissertação, não somente pela ambiguidade de seu pensamento, mas igualmente pela conclusão de seu raciocínio. ERNESTO LACLAU, a título de exemplo, muito embora aprecie a erudição de Agamben, em termos gerais traça severas críticas ao conteúdo de sua obra ${ }^{80}$, inclinando-se a uma visão mais otimista do vínculo social. PAOLO

\footnotetext{
${ }^{77}$ Essa obra, fruto de diversos seminários nos anos de 1998 e 1999, consiste na interpretação das primeiras dez palavras, literalmente, do primeiro verso da Carta de Paulo aos Romanos, em que o conceito de separação é interpretado como exceção por Agamben: Paulos doulos Christou Iésou, Klétos Apostolos Aphórismenos Eis Euaggelion Theou, em grego, traduzido ao inglês como Paul, a servant of Jesus Christ, called to be an apostle, set apart for the gospel of God.

${ }^{78}$ GAGNEBIN, Jeanne Marie. In: AGAMBEN, Giorgio. O que resta de Auschwitz: o arquivo e a testemunha. Tradução de Selvino J. Assmann. São Paulo: Boitempo, 2008, p. 11 (Apresentação).

${ }^{79}$ Nesta obra, Agamben investiga “... los modos y las razones por los que el poder ha ido asumiendo en Occidente la forma de una oikonomía, es decir, de un gobierno de los hombres”. AGAMBEN, Giorgio. El reino y la gloria: una genealogía teológica de la economía y del gobierno. Traduçao de Flavia Costa, Edgard Castro e Mercedes Ruvituso. Buenos Aires: Adriana Hidalgo, 2008, p. 9.

${ }^{806}$ I have a great admiration for the work of Giorgio Agamben. I particularly appreciate his dazzling classical erudition, his skill - both intuitive and analytical - in dealing with theoretical categories, and his ability to relate systems of thought whose connections are not immediately obvious. This appreciation does not go, however, without some deep reservations concerning his theoretical conclusions, and these reservations are what I want to elaborate upon here. If I had to put them in a nutshell, I would assert that Agamben has inverting the usual saying - the vices of his virtues. Reading his texts, one often has the feeling that he jumps too quickly from having established the genealogy of a term, a concept or an institution, to determine its actual working in a contemporary context, that in some sense the origin has a secret determining priority over what follows from it. I am not, of course, claiming that Agamben makes the naïve mistake of assuming that ethimology provides the cipher or clue to what follows from it, but, I would argue, many times his discourse
} 
VIRNO vê Agamben como um problema, um pensador sem vocação política, embora reconheça seu grande valor ${ }^{81}$, enquanto NEGRI vislumbra dois Agambens ${ }^{82}$. MATTHEW CALARCO, ao comentar as tendências da esquerda pós-moderna, qualifica Agamben como um autor dentre aqueles que firmemente questionam o capitalismo global e a própria figura do Estado. Os textos de Agamben, em sua visão, trazem os argumentos mais persuasivos disponíveis numa teoria política contemporânea a favor de uma política não-capitalista, não-Estatal, não-jurídica e não-soberana ${ }^{83}$. Seria mesmo possível uma sociedade sem separações?

Seja como for, se, de acordo com Jean-Cassien Biller e Aglá Maryoli, um dos principais temas da teoria italiana do direito é sem dúvida a maneira pela qual ela conjuga as duas tradições culturais que marcaram a teoria do direito - “... uma continental, que tem sua fonte na Teoria pura do direito de Hans Kelsen e no modelo epistemológico do empirismo lógico; outra anglo-saxônica, que tem origem na filosofia analítica da linguagem" ${ }^{84}$-, cremos que Agamben apresenta com maestria uma nova percepção da política contemporânea. Se, por outro lado, a Itália é um laboratório político como costumava repetir NORBERTO BOBBIO, ou, ainda, um laboratório de Frankenstein que também produz coisas boas, como acrescenta MiCHELANGELO BOVERO ${ }^{85}$, certamente a

remains uneasily undecided between genealogical and structural explanation. Let us take an example from Saussurean linguistics: the Latin term necare (to kill) has become in modern French noyer (to drown), and we can examine as much as we want this diachronic change in the relation between signifier and signified and we will still not find in it any explanation of the meaning resulting from their last articulation signification depends entirely on a value context which is strictly singular and which no diachronic genealogy is able to capture. This is the perspective from which we want to question Agamben's theoretical approach: his genealogy is not sensitive enough to structural diversity and, in the end, it risks ending in sheer teleology." LACLAU, Ernesto. Bare life or social indeterminacy? In: CALARCO, Matthew; DECAROLI, Steven (ed.). Giorgio Agamben: sovereignty and life. Stanford, California: Stanford University Press, 2007, p. 11.

81 VIRNO, Paolo. General intellect, exodus and multitude. Disponível em http://www.generationonline.org/p/fpvirno2.htm. Acessado em 5.8.2009.

82 "Ci sono infatti due Agamben. C'è quello che si intrattiene su uno sfondo esistenziale, destinale e terrifico, e qui è costretto ad un confronto continuo con l'idea della morte; ce n'è un altro che attraverso l'immersione nel lavoro filologico e nell'analisi linguistica, conquista (mette pezzi, manovra, costruisce) l'orizzonte biopolitico: qui, in questa situazione, Agamben sembra talvolta un Warburg dell'ontologia critica. Paradossale tuttavia è il fatto che i due Agamben convivono sempre e, quando meno te lo aspetti, il primo riemerge ed oscura il secondo, e l'ombra della morte si distende lugubre contro la voglia di vivere, contro l'eccedenza del desiderio. O il contrario". NEGRI, Antonio. Il frutto maturo della redenzione. Disponível em http://www.generation-online.org/t/negriagamben.htm. Acessado em 5.8.2009.

${ }^{83}$ CALARCO, Matthew. Op. cit., p. 163.

${ }^{84}$ BILLIER, Jean-Cassier; MARYOLI, Aglaé. História da filosofia do direito. Tradução de Maurício de Andrade. Barueri: Manole, 2005, p. 448.

${ }^{85}$ BOVERO, Michelangelo. In: BOBBIO, Norberto. Do fascismo à democracia: os regimes, as ideologias, s personagens e as culturas políticas. Tradução de Daniela Versiani. Rio de Janeiro: Elsevier, 2007, Prefácio. 
obra de Agamben é um antídoto - ou, no mínimo, um trazer à luz - contra um fascismo pós-moderno.

Os textos de Agamben pertencem àquela espécie que têm por vocação suscitar novas leituras, ângulos inéditos, e, por essa mesma razão, a facilidade de nos fascinarmos por sua convicção. Temos em mãos a obra de um filósofo definitivamente preocupado em resolver as questões de seu - nosso - tempo e, portanto, sempre em desenvolvimento. Aliás, o desenvolvimento de uma obra, seja escolar, literária ou de arte, é o elemento genuinamente filosófico para Agamben, consoante seu recente Signatura rerum: todo texto escrito é sempre o prefácio de um texto nunca escrito, de acordo com Infância e história. Isso não significa, entretanto, que sua obra está isenta de objeções e profundas reflexões, até mesmo porque os temas abordados provocam a arkhé de todos nós. Se a saída proposta à crise hoje vivenciada parece ser utópica, o raciocínio proposto expõe a essência de cada ser humano. Trata-se de um pensamento indispensável para a identificação do paradigma catastrófico da atualidade. 


\section{INTRODUÇÃO}

OBJETO INVESTIGADO: IDENTIFICAÇÃO DO DESAFIO AGAMBENIANO

$\mathrm{Na}$ introdução de Homo sacer: il potere sovrano e la nuda vita I, Giorgio Agamben expõe uma lacuna doutrinária que teria sido olvidada por ambos Michel Foucault e Hannah Arendt: de um lado, o pensador francês não teria deslocado sua investigação acerca da "importância da vida biológica e da saúde da nação como problema do poder soberano" "86 para os campos de concentração e para os grandes estados totalitários, isto é, áreas fundamentais da biopolítica moderna ${ }^{87}$; de outro lado, Arendt não teria estabelecido a conexão da biopolítica com suas análises do poder totalitário. Para o filósofo italiano:

"Que a pesquisa de Arendt tenha permanecido praticamente sem seguimento e que Foucault tenha podido abrir suas escavações sobre a biopolítica sem nenhuma referência a ela, é testemunho das dificuldades e resistências que o pensamento deveria superar nesse âmbito. E justamente a essas dificuldades devem-se provavelmente tanto o fato de que, em The human condition, a autora curiosamente não estabeleça nenhuma conexão com as penetrantes análises que precedentemente havia dedicado ao poder totalitário (das quais está ausente toda e qualquer perspectiva biopolítica), quanto à circunstância, também singular, de que Foucault jamais tenha deslocado a sua investigação para as áreas por excelência da biopolítica moderna: o campo de concentração e a estrutura dos grandes estados totalitários dos Novecentos."

\footnotetext{
${ }^{86}$ AGAMBEN, Giorgio. Homo sacer: o poder soberano e a vida nua I. Tradução de Henrique Burigo. Belo Horizonte: Editora UFMG, 2002, p. 11.

87 “Todavia Foucault... não transferiu suas escavações, como teria sido até mesmo legítimo esperar, ao que poderia apresentar-se como o local por excelência da biopolítica moderna: a política dos grandes Estados totalitários dos Novecentos. A pesquisa, que iniciou-se com a reconstrução do grand enfermement nos hospitais e nas prisões, não se conclui como uma análise do campo de concentração.” AGAMBEN, Giorgio. Homo sacer: o poder soberano e a vida nua I. Tradução de Henrique Burigo. Belo Horizonte: Editora UFMG, 2002, p. 125.

${ }^{88}$ AGAMBEN, Giorgio. Homo sacer: o poder soberano e a vida nua I. Tradução de Henrique Burigo. Belo Horizonte: Editora UFMG, 2002, p. 12.
} 
De acordo com Agamben, Foucault, pode-se afirmar, “... teria constantemente se recusado a elaborar uma teoria unitária do poder" ${ }^{\$}$, de maneira que seu abandono da abordagem tradicional do problema do poder baseada em modelos jurídicos (o que legitima o Estado?) e institucionais (o que é o Estado?) rumo a uma liberalização da soberania - é dizer, rumo aos modos concretos com que o biopoder penetra no próprio corpo de seus sujeitos e em suas formas de vida - restou incompleto ${ }^{90}$.

Paralelamente, a pesquisa de Arendt teria um limite: “... a falta de qualquer perspectiva biopolítica" "91 . Se é certo que Arendt percebeu o nexo entre domínio totalitário e a condição da vida inerente ao campo de concentração, ou laboratórios para a experimentação do domínio total, ela não teria percebido uma inquietante realidade distinta sugerida por Agamben, ou seja, “... que o processo é, de alguma maneira, inverso, e que precisamente a radical transformação da política em espaço da vida nua (ou seja, em um campo) legitimou e tornou necessário o domínio total" ${ }^{\text {"92. }}$.

Do confronto dessas duas opiniões à luz dos limites ${ }^{93}$ entre os modelos jurídico e biopolítico emerge a provocação de Agamben: “... a presente pesquisa concerne precisamente este oculto ponto de intersecção entre o modelo jurídico-institucional e o

\footnotetext{
${ }^{89}$ AGAMBEN, Giorgio. Homo sacer: o poder soberano e a vida nua I. Tradução de Henrique Burigo. Belo Horizonte: Editora UFMG, 2002, p. 13.

${ }^{90}$ Muito embora Agamben reconheça que Foucault tenha iniciado esse trabalho: "Creio que Foucault tinha razão ao dizer que queria deixar de lado os ditos 'universais' (o Estado, a Lei, a Soberania, o Poder), a fim de analisar o processo concreto e os dispositivos que realizam as relações de poder. Desta forma, ao trabalhar sobre o estado de exceção, não se tratava para mim de responder a questões como: 'O que é direito?', 'o que é o Estado?', mas de procurar compreender o modo por meio do qual a máquina políticojurídica funciona. Ou seja, não parto de questões como: 'O que é e o que não é legal?', ou mesmo 'o que é e o que não é justo?', mas 'como é possível desativar essa relação?'. Descobrir que o estado de exceção era, por assim dizer, o motor imóvel da máquina jurídica ocidental foi para mim muito instrutivo". In: A Política da profanação. Entrevista concedida à Folha de São Paulo em 18.9.2005. Disponível em HTTP://www.geocities.com/vladimirsafatle/vladi081.htm?200722. Acessado em 22.10.2007.

${ }^{91}$ AGAMBEN, Giorgio. Homo sacer: o poder soberano e a vida nua I. Tradução de Henrique Burigo. Belo Horizonte: Editora UFMG, 2002, p.125.

${ }^{2}$ AGAMBEN, Giorgio. Homo sacer: o poder soberano e a vida nua I. Tradução de Henrique Burigo. Belo Horizonte: Editora UFMG, 2002, p. 126.

93 “A questão dos limites torna-se ainda mais urgente: se são fruto dos períodos de crise política e, como tais, devem ser compreendidas no terreno político e não no jurídico-constitucional, as medidas excepcionais encontram-se na situação paradoxal de medidas jurídicas que não podem ser compreendidas no plano do direito, e o estado de exceção apresenta-se com a forma legal daquilo que não pode ter forma legal. Por outro lado, se a exceção é o dispositivo original graças ao qual o direito se refere à vida e a inclui em si por meio de sua própria suspensão, uma teoria do estado de exceção é, então, condição preliminar para se definir a relação que liga e, ao mesmo tempo, abandona o vivente ao direito”. AGAMBEN, Giorgio. Estado de exceção. São Paulo: Boitempo, 2004, p. 12.
} 
modelo biopolítico do poder" ${ }^{\prime 94}$. Isto é, Agamben propõe o desafio radical de reinterpretar institutos fundamentais do direito e da política à luz de um novo terreno em que foram intrincados os respectivos conceitos: "Somente em um horizonte biopolítico, de fato, será possível decidir se as categorias sobre cujas oposições fundou-se a política moderna (direitalesquerda; privado/público; absolutismo/democracia etc.), e que se foram progressivamente esfumando a ponto de entrarem hoje numa verdadeira e própria zona de indiscernibilidade, deverão ser definitivamente abandonadas ou poderão eventualmente reencontrar o significado que naquele próprio horizonte haviam perdido" 95 .

Esta dissertação concerne precisamente essa intersecção tal qual tratada por Agamben na forma da estrutura da exceção, que, muito embora não tenha sido objeto de uma teoria no direito público 96 , “... emerge sempre mais ao primeiro plano e tende, por fim, a tornar-se a regra" "97. O que se busca examinar é essa terra di nessuno, "terra de ninguém" 98 entre ordem jurídica e vida que se situa no limite entre a política e o direito e deixa às claras, na teoria agambeniana, o seu ponto de desequilíbrio e indiscernibilidade. Aliás, se isso for verdade, determinações basilares da relação poder e direito deverão ser revistas, pois sem sentido.

Por outras palavras, examinaremos um híbrido entre direito e fato - onde a lei se relaciona com a vida por meio de sua própria suspensão - que é hoje o paradigma dominante de governo de acordo Agamben. Essa indiscernibilidade, ou estado de exceção, na visão do filósofo italiano é o objeto de nossa investigação.

\footnotetext{
${ }^{94}$ AGAMBEN, Giorgio. Homo sacer: o poder soberano e a vida nua I. Tradução de Henrique Burigo. Belo Horizonte: Editora UFMG, 2002, p. 14.

${ }^{95}$ AGAMBEN, Giorgio. Homo sacer: o poder soberano e a vida nua I. Tradução de Henrique Burigo. Belo Horizonte: Editora UFMG, 2002, p. 12.

${ }^{96}$ Para Giorgio AGAMBEN “A contigüidade essencial entre estado de exceção e soberania foi estabelecida por Carl Schmitt em seu livro Politische Theologie (Schmitt, 1922). Embora sua famosa definição do soberano como 'aquele que decide sobre o estado de exceção' tenha sido amplamente comentada e discutida, ainda hoje, contudo, falta uma teoria do estado de exceção no direito público, e tanto juristas quanto especialistas em direito público parecem considerar o problema muito mais como uma quaestio facti do que como um genuíno problema jurídico". In: AGAMBEN, Giorgio. Estado de exceção. São Paulo: Boitempo, 2004, p. 11.

${ }^{97}$ AGAMBEN, Giorgio. Homo sacer: o poder soberano e a vida nua I. Tradução de Henrique Burigo. Belo Horizonte: Editora UFMG, 2002, p. 27.

${ }^{98}$ AGAMBEN, Giorgio. Estado de exceção. São Paulo: Boitempo, 2004, p. 12.
} 
Conquanto a Constituição da República Federativa do Brasil de 1988 tenha o caráter de marco civilizatório na história do País, consolidando-se como o instrumento mais relevante e fundamental para o processo de concretização da democracia local, há quem entenda que uma reflexão mais profunda de seu ideal democrático revela que “...o chefe do Poder Executivo da União transformou-se em verdadeiro legislador solitário da República"99, é dizer, revela o indício de uma nova técnica de governo firmada numa permanente relevância e urgência ${ }^{100}$.

Exempli gratia, o senador Garibaldi Alves Filho, então presidente do Senado, declarou: "não é exagero afirmar que, a cada medida provisória editada sem os critérios de relevância e urgência, a Constituição é rasgada com desprezo. Sob tal pano de fundo, o que se distingue é um Congresso Nacional transformado em quarto de despejo de um presidencialismo de matiz absolutista". De fato, no País, o volume de medidas provisórias, instrumentos legislativos de exceção, cresce desproporcionalmente desde a promulgação da Constituição de 1988 - a maioria delas sob as mesmas premissas do Ato Institucional n ${ }^{\circ}$ $5^{101}$ que, aliás, assemelham-se à lógica da segurança confrontada por Agamben -, assim como era corriqueiro legislar por meio do decreto-lei na pretérita Constituição ${ }^{102}$, paralisando as atividades primárias do Congresso Nacional:

"Há um evidente abuso, ou melhor, desvio do Executivo no uso das medidas provisórias, o que caracteriza um verdadeiro traço de Estado absolutista no meio de um governo republicano e democrático. Quando passa a exercer funções que seriam tipicamente próprias do Legislativo, o Executivo se

\footnotetext{
${ }^{99}$ Frase proferida pelo Ministro Celso de Mello, do Supremo Tribunal Federal brasileiro, no julgamento da Medida Cautelar na Ação Direta de Inconstitucionalidade no 4048, que visava suspender a eficácia da Medida Provisória $n^{\circ} 505 / 07$, pela qual o Presidente da República abriu crédito extraordinário para a Justiça Eleitoral e diversos órgãos do Poder Executivo. Disponível em www.stf.gov.br.

${ }^{100}$ Conforme artigo 62, caput, da Constituição Federal brasileira de 1988: Art. 62. Em caso de relevância e urgência, o Presidente da República poderá adotar medidas provisórias, com força de lei, devendo submetêlas de imediato ao Congresso Nacional.

${ }^{101}$ Que visava “... dar ao País um regime que, atendendo às exigências de um sistema jurídico e politico, assegurasse autêntica ordem democrática, baseada na liberdade, no respeito à dignidade da pessoa humana, no combate à subversão e às ideologias contrárias às tradições de nosso povo, na luta contra a corrupção, buscando, deste modo, os meios indispensáveis à obra de reconstrução econômica, financeira, politica e moral do Brasil, de maneira a poder enfrentar, de modo direto e imediato, os graves e urgentes problemas de que depende a restauração da ordem interna e do prestígio internacional da nossa pátria".

102 Cf. Tercio Sampaio FERRAZ JR. In: Decreto-lei, instrumento discricionário. Disponível em http://www.terciosampaioferrazjr.com.br/?q=/publicacoes-cientificas/36. Acessado em 12.10.2009.
} 
desvirtua e acaba se tornando um poder imperial. É uma tradição triste da cultura do País ou, a bem da verdade, da democracia ocidental..."103

Parece-nos que há efetivamente um evidente deslocamento de uma medida provisória e excepcional para uma verdadeira técnica de governo. Entretanto, seria esse deslocamento ou, quiçá, abuso de poder, suficiente para concluirmos que vivemos sob um permanente estado de exceção agambeniano?

Ou seja, seria correto afirmarmos que uma efetiva criação voluntária e préorquestrada de urgência e necessidade resultaria no estado de exceção proposto por Agamben? Há quem entenda que sim: “... as análises que estão sendo empreendidas não levam em consideração um dos fenômenos mais instigadores da realidade mundial contemporânea: a instauração cada vez mais constante de um estado de exceção. Com a estruturação deste modelo excepcional de governo, não há como se falar em democracia, isto é, em um poder advindo do povo... o estado de exceção mina completamente as bases do Estado Democrático de Direito proclamado pela Constituição de 1988"104.

FRIEDRICH MÜLLER, analisando as medidas provisórias brasileiras diante do pano de fundo das experiências alemãs, dirá que de fato a Alemanha da República de Weimar (1919-1933) conheceu algo estrutural e funcionalmente comparável às medidas provisórias, traçando até mesmo um paralelo entre o artigo 48 da Constituição de Weimar e o artigo 62 da Constituição brasileira de 1988: o direito do Presidente do Reich de editar decretos emergenciais (Notverordnungen). Assim como o pressuposto dos decretos presidenciais foram, de início, a considerável ameaça ou perturbação da segurança e ordem públicas, não tardou que o conceito fosse estendido, mais e mais, sobretudo a problemas

103 Extraído do voto do Ministro Gilmar Mendes na Medida Cautelar em Ação Direta de Inconstitucionalidade $\mathrm{n}^{\circ}$ 4.048, ajuizada pelo Partido Social Democracia Brasileira - PSDB contra o Presidente da República. Votaram pelo deferimento da liminar os Ministros Gilmar Mendes (Relator), Eros Grau, Carmem Lúcia Antunes Rocha, Carlos Ayres Britto, Celso de Mello e Marco Aurélio, vencidos os Ministros Ricardo Lewandowski, Joaquim Barbosa, Cezar Peluso, Menezes de Direito e Ellen Gracie. Disponível em www.stf.gov.br.

${ }^{104}$ HONESKO, Vitor Hugo Nicastro; HONESKO, Raquel Schlommer; BARBOSA, Tatiane Alves. O estado de exceção como causa da corrupção no sistema político-constitucional brasileiro. In: Revista do Instituto dos Advogados de São Paulo, ano 9, n. 17, janeiro-julho 2006. São Paulo: Editora Afiliada, 2006, p. 267. 
econômicos. $\mathrm{O}$ autor chega até mesmo a declarar que a decadência do artigo 62 cria um sub-reptício estado de exceção que corre o risco de se tornar crônico ${ }^{105}$.

Ou seriam as medidas excepcionais, ou mesmo o fortalecimento do Executivo, respostas legítimas e eficazes à habitual inabilidade de o Congresso Nacional brasileiro, assim como o de outros países, responder ao povo soberano, a tempo e modo devidos, ou mesmo a situações anormais ou de crise, inexistindo a fortiori qualquer desarme do ordenamento jurídico?

“Certamente não se compadece com os propósitos que inspiraram o art. 62, a incontinência com que o Executivo se tem utilizado das medidas provisórias, como se fossem instrumentos normais e corriqueiros da atividade administrativa, em vez de providências de caráter excepcional, cuja adoção deveria constituir o último, e não primeiro recurso do governo. Trai sua missão, por outro lado, o Legislativo, omitindo-se na elaboração dos diplomas necessários para complementar e regulamentar o texto constitucional. Não se pode considerar, por fim, - quem vos fala é um magistrado, e com toda a reverência devida ao E. Supremo Tribunal Federal - que o Judiciário corresponda à expectativa da Lei Maior, quando anui em declarar necessitados de regulamentação dispositivos cristalinamente auto-aplicáveis, ou quando reduz à pura e simples notificação a eficácia desse instrumento tão rico de potencialidades, precisamente na concretização de normas constitucionais, que é o mandado de injunção. A conseqüência de tudo isso é que a Constituição foi, em grande parte, congelada, se assim permitis que me expresse, como os periódicos congelamentos de preços, dos quais pouca gente, na prática, toma conhecimento." 106

Esta obra justifica-se, portanto, para desmistificar, ou não, o pensamento brasileiro generalizado de que o mero exercício, ainda que excessivo ou abusivo, de medidas

\footnotetext{
${ }^{105}$ MÜLLER, Friedrich. As medidas provisórias no Brasil diante do pano de fundo das experiências alemãs. In: GRAU, Eros Roberto; FILHO, Willis Santiago Guerra (org.). Direito constitucional: estudos em homenagem a Paulo Bonavides. São Paulo: Malheiros, p. 337-355.

${ }^{106}$ MOREIRA, José Carlos Barbosa. O Transitório e o Permanente no Direito. In: Temas de Direito Processual, Quinta Série, p. 230.
} 
extraordinárias no País seja per se caracterizador de um estado de exceção, ao menos nos moldes agambenianos.

Frise-se, desde já, portanto, que a referência feita acima às medidas provisórias - a título de mero exemplo, porquanto outros institutos poderiam ser mencionados - deve-se exclusivamente para demonstrarmos que há uma percepção difusa no sentido de que convivemos sob uma nova técnica de governo sob as vestes de um Estado de Direito.

Ressalte-se, igualmente, que não se pretende aqui adequar o pensamento de Agamben à ordem jurídica ou à realidade política brasileiras, o que demandaria análises histórica, econômica e sociológica, entre outras. É dizer, justifica-se esta obra não para qualificar este ou aquele país, inclusive o Brasil, sob o domínio do estado de exceção agambeniano, mas para questionarmos os próprios fundamentos desse fenômeno teorizado pelo filósofo italiano, que ainda hoje é pouco debatido localmente. Justifica-se o estudo unicamente para contribuirmos na superação de uma lacuna latente na doutrina pátria bem captada pelo Ministro EROS GRAU, em apresentação à tradução de Politische Theologie:

"É realmente curioso que o tema da exceção não tenha exercido fascínio sobre os nossos juristas, o que há de ser atribuído ao prestígio que assumiu entre nós, desde o século passado, o pensamento kelseniano. Carl Schmitt, aliás, com indisfarçável ponta de ironia, observa ser natural que um neo-kantiano como Kelsen não saiba, por definição, o que fazer com a situação excepcional."107

Gilberto BerCOVici igualmente destaca essa lacuna ao explicitar que “... Agamben retoma este tema - geralmente ignorado pelos juristas - em um estudo que vai da história do conceito de exceção à sua conturbada atualidade no pós-11 de Setembro", descrevendo, em apresentação à tradução de Stato di Eccezione, que:

"Para o autor, as democracias ocidentais vivem um processo de rompimento com o antigo nomos da Terra, levando à ruína o sistema de limitações recíprocas. $\mathrm{O}$ fundamento oculto desse rompimento é a exceção soberana, e o que presenciamos é a irrupção desse estado para além de seus limites.

107 GRAU, Eros Roberto. In: SCHMITT, Carl. Teologia Política. Tradução de Elisete Antoniuk. Belo Horizonte: Del Rey Internacional, 2006, p. xiii. 
Estabelecendo uma relação entre direito e violência (em que esclarece os equívocos criados em torno do tema da segurança), demonstra que o ordenamento jurídico contém em si o seu contrário: a suspensão dos direitos, que admite uma violência não regulada pela lei, na qual o estado de exceção se torna uma estrutura jurídico-política estabelecida. Este é o prenúncio do novo nomos da Terra." 108

Dentro dessa profusão de problemas, trataremos de temas controversos tais como política, biopolítica, vida, soberania, pouvoir constitué, poder, direito e norma, que por si só são objeto de teorias próprias, bem como compêndios específicos, e, principalmente, a relação e/ou dialética que os une, ou mesmo os torna indiscerníveis, nos estritos limites necessários à investigação do estado de exceção agambeniano.

Não é demais ressaltarmos, destarte, que, conquanto tenhamos a pretensão de qualificar esses fenômenos visando à elaboração de uma crítica do estado de exceção agambeniano, não é a intenção desta obra - e nem seria aqui cabível - examinarmos exaustivamente todas as vertentes e acaloradas discussões que permeiam cada um desses assuntos. Isto é, os pontos relacionados ao conceito de estado de exceção são abordados, porém não com o mesmo detalhe, uma vez que não fazem parte do objetivo central. Repita-se: não é objeto desta dissertação uma teoria da soberania ou uma teoria do Estado e sua evolução. Muito embora analisemos sucintamente tópicos imprescindíveis à compreensão do estado de exceção, limitamos nossos esforços no marco estritamente indispensável para o pensamento crítico do objeto desta dissertação.

Ademais, o objetivo dos comentários que se seguem não é qualificar as teses de Agamben como corretas ou verdadeiras, mas tentar compreendê-las. No máximo, tentamos colocar em evidência coerências e dissonâncias, de maneira que possamos prestar homenagem à sua lucidez ou, se for o caso, criticar o que nos parece discutível.

Outrossim, embora a análise da totalidade da filosofia agambeniana seja relevante para a interpretação de sua teoria do estado de exceção, não é foco desta dissertação interpretar as suas diversas vertentes; seria ir longe demais. O estudo está focado no

\footnotetext{
${ }^{108}$ BERCOVICI, Gilberto. Estado de exceção. Tradução de Iraci D. Poleti. São Paulo: Boitempo, 2004,
} Apresentação. 
conceito de estado de exceção agambeniano como paradigma político-jurídico de nossas vidas.

\section{Plano da ObRa}

Nessa empreitada, descreveremos, no primeiro capítulo, as diversas conceituações semânticas que Agamben dá ao termo vida e sua relação com o poder soberano, inclusive numa sociedade de normalização que prestigia a administração da vida em detrimento da morte, de maneira que possamos, ato contínuo, caracterizar o protagonista da obra agambeniana, a vida nua. Nesse fio-condutor, analisaremos as maneiras pelas quais a vida foi politizada num confronto entre Foucault e Agamben, traçando os efeitos, eventualmente semelhantes, da biopolítica no totalitarismo moderno e nas democracias atuais. Procuraremos desenvolver as afinidades e divergências entre os dois pensadores principalmente para identificarmos que, em Agamben, a produção de um corpo biopolítico não é inauguração moderna, mas atividade originária do poder soberano.

O capítulo dois busca apresentar o caráter ontológico da política e da autonomia da potência que rege toda a teoria agambeniana. A partir daí, ilustraremos criticamente os raciocínios de Walter Benjamin e Carl Schmitt, em confronto a outros autores, quanto ao estado de exceção e ao paradoxo da soberania, para finalmente adentrarmos especificamente na exceção soberana agambeniana, uma figura em que factum e ius se tornam indiscerníveis e homines sacri são produzidos a esmo, não olvidando a relação de exclusão inclusiva, de abandono, que a norteia e revela o verdadeiro vínculo social. Versaremos sobre o papel da linguagem na reflexão proposta por Agamben e como ele debate a problemática do poder constituinte e, por fim, esclareceremos a noção de homo sacer e a relação de banimento a ele inerente, traçando paralelos entre a condição jurídica no campo, enquanto paradigma de governo em Agamben, e a condição de vida nua do cidadão moderno, sempre trazendo à baila visões e obras comparativas.

O capítulo três tem como objetivo elucidar o caminho pelo qual Agamben vislumbra uma nova forma-di-vita que não seja inaugurada pela política soberana e por sua relação de banimento, isto é, uma comunità che viene que possa desativar a máquina biopolítica produtora da vida nua e torne inoperante o atual conceito de político-jurídico: uma nova comunidade que pense além da soberania, do bando soberano e do próprio 
direito. Trata-se de uma provocativa análise em busca de uma comunidade sem identidade, sem propriedades e destinos, mas que seja pura potencialidade, que seja em si como ela é, quer dizer, que não possua qualquer tarefa enquanto fim, mas tão somente meios sem fins.

Finalmente, nas considerações finais, visamos destacar nossas reflexões acerca dos fundamentos da teoria agambeniana e expor, por consequência, nossas próprias conclusões quanto às propostas por ele apresentadas.

Quanto às fontes, foram utilizadas quatro espécies: obras do próprio Agamben e respectivas traduções, que englobam também entrevistas e artigos; obras de comentadores do pensamento de Agamben; obras de outros autores, que incluem visões do estado de exceção e demais temas tratados nesta dissertação; obras de cunho geral relacionadas à filosofia do direito.

Quanto às referências bibliográficas, foram utilizadas nas citações, para as obras de Agamben, preferencialmente as traduções em português. Essas foram confrontadas com obras em outras línguas, sempre tentando manter o sentido original do pensamento agambeniano.

Por fim, impende salientar, uma vez mais, que Agamben não desenvolveu seu pensamento de forma sistemática e sua obra, vista por esse prisma, carece de maior unidade. Assim, os capítulos não estão organizados como partes sucessivas de um argumento, mas como tentativa de exploração de diferentes facetas de uma mesma questão ou, caso se prefira, como variações em torno de um mesmo tema.

Desse modo, em que pesem os inúmeros e cautelosos estudos dos textos que baseiam esta dissertação, queremos crer que as conclusões trazidas abaixo de maneira alguma substituirão a leitura das próprias obras. Trata-se tão somente de uma interpretação que, conquanto motivada pelo interesse de desvendar a doutrina do autor - mas sob o espírito de contribuir aos estudos da relação direito e poder - pode ser infiel às formulações do próprio Agamben. 


\section{CAPÍTULO 1 BIOPODER}

No conjunto de sua obra, Michel Foucault leciona que o regime político que emergiu a partir do século XVII e seguintes envolve uma reversão fundamental do princípio da operação do poder até então existente. O pensador francês entende que, enquanto o poder soberano pretérito operava com base no princípio do direito de obrigar seus sujeitos à morte - o poder e, em última instância, o direito de vida e de morte ${ }^{109}$-, a biopolítica $^{110}$ moderna reverte essa premissa e opera por meio da administração da vida. Em outras palavras, Foucault abandona a teoria político-jurídica do poder estatal focada sobretudo na figura do soberano para prestigiar a emergência da gestão da vida nos mecanismos do poder ${ }^{111}$. Em poucas palavras, essa transição reflete o próprio limiar da modernidade em Foucault.

Entretanto, é justamente essa pretensa passagem que fundamenta a intenção de Agamben corrigir e, paralelamente, integrar ${ }^{12}$ (integratta), a análise de Foucault acerca da relação entre biopolítica e poder soberano, até mesmo para aperfeiçoar sua própria teoria sobre o estado de exceção.

\footnotetext{
${ }^{109}$ Ao comentar o pensamento de Foucault, Agamben esclarece que a primeira vez que a expressão direito de vida e de morte aparece na história do direito é na fórmula vitae necisque potestas, "que não designa de modo algum o poder soberano, mas o incondicional poder do pater sobre os filhos homens... este poder é absoluto e não é concebido nem como a sanção de uma culpa nem como a expressão do mais geral poder que compete ao pater enquanto chefe da domus: ele irrompe imediatamente e unicamente da relação paifilho (no instante em que o pai reconhece o filho varão alçando-o do solo adquire sobre ele o poder de vida e de morte) e não deve, por isso, ser confundido com o poder de matar que pode competir ao marido ou ao pai sobre a mulher ou sobre a filha surpreendidas em flagrante adultério, e ainda menos com o poder do dominus sobre seus servos. Enquanto estes poderes concernem ambos à jurisdição do chefe de família e permanecem, portanto, de algum modo no âmbito da domus, a vitae necisque potestas investe ao nascer todo cidadão varão livre e parece assim definir o próprio modelo do poder político em geral. Não a simples vida natural, mas a vida exposta à morte (a vida nua ou a vida sacra) é o elemento político originário". AGAMBEN, Giorgio. Homo sacer: o poder soberano e a vida nua I. Tradução de Henrique Burigo. Belo Horizonte: Editora UFMG, 2002, p. 95.

110 “... bio-política, ou seja, a crescente implicação da vida natural do homem nos mecanismos e nos cálculos de poder". AGAMBEN, Giorgio. Homo sacer: o poder soberano e a vida nua I. Tradução de Henrique Burigo. Belo Horizonte: Editora UFMG, 2002, p. 125.

${ }^{111} \mathrm{O}$ poder, que outrora havia meramente destruído o corpo do indivíduo, assume o controle sobre ele. Esse raciocínio é identificado nas primeiras páginas de Vigiar e punir, em que Foucault narra a execução da condenação de Damiens e a extinção da "melancólica festa de punição" que se assistia até o fim do século XVIII. In: FOUCAULT, Michel. Vigiar e Punir: nascimento da prisão. Tradução de Raquel Ramalhete. 36 ed. Rio de Janeiro: Vozes, 2009.

${ }^{112}$ Cf. Giorgio AGAMBEN. In: Homo sacer: o poder soberano e a vida nua I. Tradução de Henrique Burigo. Belo Horizonte: Editora UFMG, 2002, p. 16.
} 
Agamben sustenta que a relação entre biopolítica e soberania não é característica somente da era moderna como crê Foucault, mas articulada num mecanismo muito mais fundamental e originário. Para o filósofo italiano, "Pode-se dizer, aliás, que a produção de um corpo biopolítico seja a contribuição original do poder soberano" ${ }^{, 13}$ (Si può dire, anzi, che la produzione di un corpo biopolitico sia la prestazione originale del potere sovrano).

Por essa razão, antes de adentrarmos propriamente no terreno da exceção agambeniana, cumpre-nos estabelecer algumas premissas críticas quanto à biopolítica e seus contornos no pensamento desses doutrinadores, o que faremos nos limites indispensáveis para a subsequente compreensão do estado de exceção.

\subsection{Politização da VIDA}

\subsubsection{A emergência da biopolítica}

A bem da verdade, o conceito de biopolítica - enquanto elemento do biopoder, ao lado da disciplina - não é um dos títulos principais da obra de Foucault. Segundo PAUL PATTON, biopoder aparece pela primeira vez na doutrina foucaultiana numa aula proferida em 17 de março de 1976, e, subsequentemente, nas páginas de Histoire de la sexualité I: la volonté de savoir, publicado no mesmo ano ${ }^{114}$.

Posteriormente, a análise específica do tema teria sido colocada de lado em benefício de outros objetos de estudo como os mecanismos de segurança, o liberalismo, o neoliberalismo e as tecnologias do savoir/pouvoir ${ }^{115}$, muito embora estes sejam intimamente relacionados ao biopoder em nosso entendimento. Para PAUL PATTON, o fato de a biopolítica não ter sido objeto de uma coesa teoria foucaultiana sugere que, ao

\footnotetext{
${ }^{113}$ AGAMBEN, Giorgio. Homo sacer: o poder soberano e a vida nua I. Tradução de Henrique Burigo. Belo Horizonte: Editora UFMG, 2002, p. 14.

${ }^{114}$ Cf. Paul PATTON. In: Agamben and Foucault on biopower and biopolitics. In: CALARCO, Matthew; DECAROLI, Steven (ed.). Giorgio Agamben: sovereignty and life. Stanford, California: Stanford University Press, 2007, p. 206.

${ }^{115}$ Com relação ao saber/poder, o século XVIII instituiu, para Foucault, com as disciplinas e a normalização, um poder que não é ligado ao desconhecimento, mas que só funciona graças à formação de um saber, que é para esse poder tanto um efeito como uma condição de seu exercício. Cf. Michel FOUCAULT. In: Os anormais: curso no Collège de France (1974-1975). Tradução de Eduardo Brandão. São Paulo: Martins Fontes, 2001, p. 65.
} 
contrário do que entende Agamben ${ }^{116}$, problemas internos do próprio conceito preveniram o desenvolvimento dessa doutrina ${ }^{117}$.

É nesse sentido que o curso ministrado no Collège de France em 1978-79, que seria focado principalmente no nascimento da biopolítica, teve uma mudança de rumo, porquanto o filósofo francês teria decidido se aprofundar no estudo da arte liberal de governo, deixando a analítica da biopolítica para um momento posterior ${ }^{118}$. Aliás, o próprio Foucault esclarece que esse curso, que deveria examinar principalmente a biopolítica, “... acabou sendo inteiramente consagrado ao que devia formar apenas a sua introdução" 119 . Ou seja, o tema do liberalismo - em sua formulação original e suas versões contemporâneas -, que deveria ser unicamente objeto da primeira parte do curso, para depois se chegar ao problema da política da vida, foi analisado mais demoradamente do que se previa. No entanto, em que pesem os acasos acadêmicos, encontramos elementos suficientes para a conceituação da biopolítica na teoria do pensador francês para que possamos, ato contínuo, analisar o estado de exceção agambeniano.

\footnotetext{
116 Para quem "... a morte impediu que Foucault desenvolvesse todas as implicações do conceito de biopolítica e mostrasse em que sentido teria aprofundado ulteriormente a sua investigação". In: AGAMBEN, Giorgio. Homo sacer: o poder soberano e a vida nua I. Tradução de Henrique Burigo. Belo Horizonte: Editora UFMG, 2002, p. 12.

${ }^{117}$ PATTON, Paul. Op. cit., p. 206.

118 "Foucault's 1977-78 course, Sécurité, territoire, population, began with the statement that he would undertake a further study of the mechanisms by which the biological existence of the human species became the object of political intervention and strategy. Accordingly, the first three lectures addressed mechanisms of security, by contrast with disciplinary mechanisms, in relation to a series of examples such as the management of urban spaces and epidemics. By the fourth lecture, however, the focus shifted to the arts of government and the problematic of governmentality which occupied center stage for the remainder of this course and for the entire course the following year... Although Foucault's 1978-79 course was entitled Birth of Biopolitics, the focus was on particular forms of governmental reason, namely liberalism and post-World War II neo-liberal variants. At the end of the first lecture, Foucault justified his shift of focus by the suggestion that the liberal art of government provided the specific system of governmental reason and therefore the historical framework within which the techniques of biopower would be deployed. Thereafter, 'biopower' is only mentioned in passing in the course of the lectures themselves... The concept of biopower thus plays no role in Foucault's work after 1976. How did it function in the lecture in which it was introduced? The lecture on March 17, 1976, was the final lecture in a course devoted to the themes of war and race and the role that these played in seventeenth- and eighteenth-century history and political thought. Toward the end of this lecture, Foucault refers to the previous discussion of biopower as a 'long digression' into which he had entered in order to provide an explanation of how it came about that racism became 'inscribed as the basic mechanism of power, as it is exercised in modern states'. In apparent anticipation of Agamben's thesis concerning the biopolitical character of politics today, he suggests that modern states 'can scarcely function without becoming involved with racism at some point"'. PATTON, Paul. Op. cit., p. 206207.

${ }^{119}$ FOUCAULT, Michel. Nascimento da biopolítica: curso no Collège de France (1978-1979). Tradução de Eduardo Brandão. São Paulo: Martins Fontes, 2008, p. 431.
} 
A melhor definição foucaultiana, em nosso entendimento, deriva de um confronto com a concepção aristotélica do homem encontrada no primeiro volume de História da sexualidade: "O homem, durante milênios, permaneceu o que era para Aristóteles: um animal vivo e, além disso, capaz de existência política; o homem moderno é um animal, em cuja política, sua vida de ser vivo está em questão"120.

Isto é, a fronteira da modernidade foucaultiana é a transformação da política em biopolítica à luz dos mecanismos pelos quais o poder estatal veio a ser exercido - em cadeia $^{121}$ - sobre a vida humana. É nessa direção que, queremos crer, uma das figuras mais persistentes no trabalho desse autor é a busca de uma nova teoria centrada no como ao invés de no porquê do poder $^{122}$. De fato, Foucault nega a abordagem tradicional da teoria do poder baseada exclusivamente em modelos jurídicos, relacionados à legitimação do poder, e institucionais, relacionados à teoria do Estado, e sugere um modelo biopolítico ${ }^{123}$. Para o pensador, “... eu entendia por isso (biopolítica) a maneira como se procurou, a partir do século XVII, racionalizar os problemas postos à prática governamental pelos fenômenos próprios de um conjunto de viventes constituídos em população: saúde, higiene, natalidade, longevidade, raças... Sabe-se o lugar crescente que esses problemas ocuparam desde o século XIX e que desafios políticos e econômicos eles vêm constituindo até hoje" $e^{\text {124. }}$

\footnotetext{
${ }^{120}$ Cf. Michel FOUCAULT. In: História da sexualidade I: vontade de saber. Tradução de Maria Thereza da Costa Albuquerque e J. A. Guilhon Albuquerque. 19 ed. Rio de Janeiro: Graal, 1988, p. 156.

${ }^{121}$ Para Foucault, não devemos tomar o poder “.... como um fenômeno de dominação maciço e homogêneo de um indivíduo sobre os outros, de um grupo sobre os outros, de uma classe sobre as outras; mas ter bem presente que o poder - desde que não seja considerado de muito longe - não é algo que se possa dividir entre aqueles que o possuem e o detêm exclusivamente e aqueles que não o possuem e lhe são submetidos. O poder deve ser analisado como algo que circula, ou melhor, como algo que só funciona em cadeia". In: FOUCAULT, Michel. Microfísica do poder. Tradução de Roberto Machado. Rio de Janeiro: Edições Graal, 1979, p. 183.

${ }^{122}$ Para Agamben, “... Foucault, como sabem, sempre recusou a se ocupar daquelas categorias gerais ou entes da razão que chama de 'os universais' (les universaux), como o Estado, a Soberania, a Lei, o Poder. Mas isso não significa que não haja, no seu pensamento, conceitos operativos de caráter geral". In: AGAMBEN, Giorgio. O que é contemporâneo? e outros ensaios. Tradução Vinícius Nicastro Honesko. Chapecó: Argos, 2009, p. 33.

${ }^{123}$ Em outras palavras, o poder deixa de ser uma instituição e uma estrutura para se tornar uma "... situação estratégica complexa numa sociedade determinada". Cf. Michel FOUCAULT. In: História da sexualidade I: vontade de saber. Tradução de Maria Thereza da Costa Albuquerque e J. A. Guilhon Albuquerque. 19. ed. Rio de Janeiro: Graal, 1988, p. 103.

${ }^{124}$ FOUCAULT, Michel. Nascimento da biopolítica: curso no Collège de France (1978-1979). Tradução de Eduardo Brandão. São Paulo: Martins Fontes, 2008, p. 431.
} 
A inovação, segundo PELBART ${ }^{125}$, é que a vida entra na história, no sentido de que os fenômenos da espécie humana entram na ordem do saber e nos cálculos do poder, ou seja, no campo das técnicas políticas, que se tornam agentes de transformação da vida. Por outras palavras, Foucault se refere à forma pela qual o poder estatal é efetivamente exercido - partindo de técnicas e mecanismos disciplinares então inaugurados - e não à sua representação nas teorias da soberania. O poder não é mais descrito em termos da representação jurídica e política do poder soberano, mas sim, “... partindo de baixo, a maneira como os mecanismos de controle puderam funcionar; por exemplo, quanto à exclusão da loucura ou à repressão e proibição da sexualidade, ver como, ao nível efetivo da família, da vizinhança, das células ou níveis mais elementares da sociedade, esses fenômenos de repressão ou exclusão se dotaram de instrumentos próprios, de uma lógica própria, responderam a determinadas necessidades"126.

\subsubsection{Direito de vida e morte}

De tal modo, a referência ao poder soberano revela a divergência entre um poder pretérito que interveio na vida unicamente para impor a morte ${ }^{127}$, e outro, aplicável na modernidade, consoante Foucault, que intervém nas condições que sustentam a vida: a biopolítica.

Até o século XVIII, o poder soberano tinha um poder de morte segundo Foucault $^{128}$, ou seja, o poder de negar, barrar, destruir ou eliminar ${ }^{129}$ - MÁRCIO ALVES DA

\footnotetext{
${ }^{125}$ PELBART, Peter Pál. Vida capital: ensaios de biopolítica. São Paulo: Iluminuras, 2003, p. 58.

${ }^{126}$ FOUCAULT, Michel. Vigiar e Punir: nascimento da prisão. Tradução de Raquel Ramalhete. 36. ed. Rio de Janeiro: Vozes, 2009, p. 185.

127 "Se fizéssemos uma história do controle social do corpo, poderíamos mostrar que, até o século XVIII inclusive, o corpo dos indivíduos é essencialmente a superfície de inscrição de suplícios e de penas; o corpo era feito para ser supliciado e castigado. Já nas instâncias de controle que surgem a partir do século XIX, o corpo adquire uma significação totalmente diferente; ele não é mais o que deve ser supliciado, mas o que deve ser formado, reformado, corrigido, o que deve adquirir aptidões, receber um certo número de qualidades, qualificar-se como corpo capaz de trabalhar". FOUCAULT, Michel. A verdade e as formas jurídicas. Tradução de Roberto Cabral de Melo Machado e Eduardo Jardim Morais. Rio de Janeiro: NAU Ed., 2003, p. 119.

${ }^{128}$ Ainda que esse direito de vida e morte fosse relativo e limitado à existência do próprio soberano, ou seja, um direito que já não é um privilégio absoluto (tal como na fórmula patria potestas, em que o pai romano podia dispor da vida de seus filhos já que as tinha dado), mas condicionado à sobrevivência do soberano. Cf. Michel FOUCAULT. In: História da sexualidade I: vontade de saber. Tradução de Maria Thereza da Costa Albuquerque e J. A. Guilhon Albuquerque. 19 ed. Rio de Janeiro: Graal, 1988, p. 147.

${ }^{129}$ Impende salientarmos que, na discussão do direito de morte no biopoder, matar não significa simplesmente assassinar, mas igualmente toda forma de morte indireta: o fato de expor alguém à morte, majorar o risco de morte de alguém, ou simplesmente morte política, expulsão, rejeição e assim por diante.
} 
FONSECA remete-se à noção de exclusão ${ }^{130}$-, enquanto a partir desse período verifica-se um poder destinado a “... produzir forças, a fazê-las crescer e ordená-las"”131. Enquanto a anterior forma de poder unicamente tirava a vida ${ }^{132}$ ou deixava viver, isto é, “... o direito de causar a morte ou de deixar viver" ${ }^{\prime 133}$, a biopolítica na modernidade pode fazer viver ou deixar morrer ${ }^{134}$ : fazer morrer e deixar viver em contraste ao fazer viver e deixar morrer $^{135}$.

Foucault, portanto, contrasta o novo biopoder com a anterior forma de poder soberano que dá e tira a vida ${ }^{136}$. Para ele, o aparecimento histórico do biopoder leva diretamente a uma transformação das racionalidades caracterizadas pelo direito sobre a vida e sobre a morte rumo a um poder focado no investimento sobre a vida. Explica-se: Foucault vê no antecedente paradigma uma inapropriedade na maneira em que a vida e a morte materiais do indivíduo são duplicadas em direitos soberanos sobre vida e a morte. Para a teoria tradicional da soberania, a vida e a morte dos indivíduos tornaram-se tão

\footnotetext{
${ }^{130}$ Enquanto “... excluir, separar, limitar, reprimir". Cf. Márcio Alves da FONSECA. In: Michel Foucault e o direito. Tese de doutorado apresentada à Faculdade de Direito da Universidade de São Paulo, 2001, acervo Dedalus, Tomo 32950/02, p. 159.

${ }^{131}$ Cf. Michel FOUCAULT. In: História da sexualidade I: vontade de saber. Tradução de Maria Thereza da Costa Albuquerque e J. A. Guilhon Albuquerque. 19. ed. Rio de Janeiro: Graal, 1988, p. 148.

${ }^{132}$ Num interessante reflexo desse pensamento no Brasil, Daniel ALVES e Mauro MEIRELLES concluem que: "Encaminhando o final dessa análise, podemos desviar nosso foco das diferenças internas e constatar que, no conjunto dos dados 49\% dos entrevistados concordam totalmente, ou tendem a concordar, que a pena de morte é aceitável em caso de crimes hediondos. Assim como na pesquisa citada pela reportagem da Superinteressante, os dados que obtivemos apontam para uma cisão entre o público contrário e a favor de uma solução radical para o problema da violência. O que, por si só, é preocupante, na medida em que metade dos formadores de opinião apóia a sujeição do direito à vida pelo Estado. Aponta-se, segundo os dados coletados, mais alguns elementos para complementar a questão da relação com o Estado: mais de $70 \%$ dos entrevistados foram pelo menos simpáticos às frases que afirmavam que a polícia deveria ser mais rigorosa, que o Brasil é o país da impunidade e que não existe, em curto prazo, solução para a corrupção no país". ALVES, Daniel; MEIRELLES, Mauro. Humanismo latino e opiniões acerca da pena de morte. In: BOMBASSARO, Luiz Carlos Bombassaro; RI JR., Arno Dal; PAVIANI, Jayme Paviani (org.). As interfaces do humanismo latino. Porto Alegre: EDIPUCRS, 2004, p. 274.

${ }^{133}$ Cf. Michel FOUCAULT. In: História da sexualidade I: vontade de saber. Tradução de Maria Thereza da Costa Albuquerque e J. A. Guilhon Albuquerque. 19. ed. Rio de Janeiro: Graal, 1988, p. 148.

${ }^{134}$ Nas palavras de Paul Patton: "The reference to sovereign power draws us back to the primary contrast that frames the concept of biopower, namely, the contrast between a power that intervened on the conditions that sustain life and one that intervened on life only by imposing death, between a power that could make live or let die and one that could only take life or let live". Op. cit., p. 212.

${ }^{135}$ Cf. Giorgio AGAMBEN. In: O que resta de Auschwitz: o arquivo e a testemunha. Tradução de Selvino J. Assmann. São Paulo: Boitempo, 2008, p. 88.

${ }^{136}$ Impende frisar que, conquanto a soberania clássica trate do direito sobre a vida e a morte, esse direito reflete, a bem da verdade, um direito de matar, uma vez que o efeito do poder soberano sobre a vida é exercido unicamente quando o soberano pode matar, de maneira que a essência do direito à vida e à morte é na verdade o direito de matar. Há um desequilíbrio da relação. Em outras palavras, como Foucault revela em Vigiar e Punir, o exercício do poder soberano no período pré-moderno foi primordialmente negativo. Ele tomou a vida, ou a ameaçou a fazê-lo, assim como recolhia tributos e outros deveres.
} 
somente direitos em razão da vontade do soberano. O corpo físico do indivíduo é, portanto, duplicado em sua relação com a vontade do soberano em virtude de seu status legal.

Esse direito - de vida e morte - seria filosoficamente inconciliável porque, na extensão em que o soberano realmente detém o poder para decidir sobre a vida e a morte dos indivíduos, o sujeito seria assim suspenso entre elas. Qualquer sujeito não teria o direito de viver ou morrer independentemente da vontade do soberano. Quer dizer, em termos da relação com o soberano, o indivíduo é, por direito, nem morto, nem vivo ${ }^{137}$. Do ponto de vista de vida ou morte, o sujeito é neutro, e é graças ao soberano que o indivíduo tem o direito de estar vivo ou, possivelmente, o direito de estar morto.

Declarando essa concepção incompatível com a modernidade ${ }^{138}$, o biopoder foucaultiano é investido na regularização da vida por meio da operação da normalização e do controle dos elementos aleatórios da vida do $\operatorname{corpo}^{139}$ e da população. Ele busca melhorar a vida pela eliminação de acidentes, de elementos contingentes e suas deficiências, isto é, por meio de um processo de normalização. Biopoder, portanto, não resulta num direito sobre a morte para Foucault ${ }^{140}$. Na verdade, ele sugere que, dentro do biopoder, a morte é em si relegada às margens do poder político: ela não é mais uma manifestação do poder do soberano, mas indica precisamente os limites desse poder, o momento em que a vida escapa das mãos da governança.

\footnotetext{
${ }^{137}$ Aqui há uma direta relação com o pensamento de Agamben, como veremos abaixo, porquanto o estado do corpo poderia ser entendido como pura potencialidade.

138 “... Mas, nos séculos XVII e XVIII, ocorre um fenômeno importante: o aparecimento, ou melhor, a invenção de uma nova mecânica de poder, com procedimentos específicos, instrumentos totalmente novos e aparelhos bastante diferentes, o que é absolutamente incompativel com as relações de soberania". FOUCAULT, Michel. Microfísica do poder. Tradução de Roberto Machado. Rio de Janeiro: Edições Graal, 1979, p. 187.

139 A penetração do poder no corpo é descrito nos seguintes termos: "O domínio, a consciência de seu próprio corpo só puderam ser adquiridos pelo efeito do investimento do corpo pelo poder: a ginástica, os exercícios, o desenvolvimento muscular, a nudez, a exaltação do belo corpo... tudo isto conduz ao desejo de seu próprio corpo através de um trabalho insistente, obstinado, meticuloso, que o poder exerceu sobre o corpo das crianças, dos soldados, sobre o corpo sadio. Mas, a partir do momento em que o poder produziu este efeito, como conseqüência direta de suas conquistas, emerge inevitavelmente a reivindicação de seu próprio corpo contra o poder, a saúde contra a economia, o prazer contra as normas morais de sexualidade, do casamento, do pudor. E, assim, o que tornava forte o poder passa a ser aquilo por que ele é atacado...". f. Michel FOUCAULT. In: Microfísica do poder. Tradução de Roberto Machado. Rio de Janeiro: Edições Graal, 1979, p. 146.

${ }^{140}$ É nesse sentido que, a partir de então, “... a pena capital é, ao mesmo tempo, o limite, o escândalo e a contradição". Cf. Michel FOUCAULT. In: História da sexualidade I: vontade de saber. Tradução de Maria Thereza da Costa Albuquerque e J. A. Guilhon Albuquerque. 19. ed. Rio de Janeiro: Graal, 1988, p. 150.
} 
Com efeito, visto que o biopoder é integralmente direcionado a patrocinar a vida, quando ele falha, ou quando a forma de vida em jogo é considerada não-vivível, ela é simplesmente deixada a seus próprios recursos e permitida a morrer. Por essa razão, a biopolítica causa a vida ou simplesmente a devolve à morte ${ }^{141}$. Assim, a morte não é simplesmente desconhecida pelo pensador francês. Nesse contraste de afirmações, Foucault assevera, no curso de 1976, que a morte é de fato incorporada no biopoder por meio do racismo. Sem adentrar a fundo em sua sustentação quanto ao tema, o racismo, para ele, é precisamente o caminho de introduzir-se uma fratura no domínio da vida. Isso significa que, para o estado moderno, racismo é uma condição indispensável para a instalação da morte no espectro de um poder que patrocina a vida. Racismo justifica e torna possível, portanto, a instalação - aparentemente paradoxal - da morte no regime do biopoder, e isso é obtido justamente por meio de uma regulação normalizadora que fragmenta o campo do biológico que, por sua vez, é controlado pelo poder. Quer dizer, por meio da inauguração de uma fissura dentro da continuidade dirigida pelo biopoder.

Desse modo, as forças normalizadoras do racismo - que autorizam a fratura biológica de uma população - são os mecanismos pelos quais o poder soberano consegue ser exercido. Racismo parece ser assim não somente uma técnica do biopoder, mas uma condição para o poder soberano exercer os instrumentos, mecanismos e tecnologias da normalização. É exatamente esse, para Foucault, o ponto de articulação entre soberano e biopoder.

Porém, como veremos abaixo, não somente o racismo não é o vínculo que une biopoder e soberania para Agamben, como o próprio objeto do corpo biopolítico entre as duas proposições é inconfundível.

\subsubsection{Biopolítica e disciplina}

A partir do Renascimento, “... introduz-se uma nova forma de relação, que não é poder sobre objetos, riqueza, mas poder sobre o corpo e seus atos, o poder sobre o

\footnotetext{
${ }^{141}$ Cf. Michel FOUCAULT. In: História da sexualidade I: vontade de saber. Tradução de Maria Thereza da Costa Albuquerque e J. A. Guilhon Albuquerque. 19. ed. Rio de Janeiro: Graal, 1988, p. 150.
} 
trabalho" ${ }^{\text {142 }}$. A transformação da política, segundo Foucault, deu-se por meio de uma virada nas racionalidades operativas das tecnologias do poder - de um poder de dedução para um poder de produção - qualificada por dois eventos normalizadores históricos.

O primeiro deles é a emergência de técnicas disciplinares do poder guiadas pela necessidade de tutelar as forças do corpo do indivíduo (ou "técnicas e táticas de dominação" ${ }^{143}$ ). Esse poder disciplinar ${ }^{144}$, que assinala novos padrões de regulação social, não mais opera por meio da violência imposta nos sujeitos de cima para baixo ${ }^{145}$, mas por meio de uma regulação normalizadora que administra e patrocina a vida dos sujeitos ${ }^{146}$.

O segundo é a biopolítica, já tratada acima em termos gerais, guiada para regular e administrar a vida de um novo sujeito político, a população. De fato, a biopolítica foucaultiana opera numa distinta escala das técnicas disciplinares: populações ao invés de corpos individuais ${ }^{147}$. Nesse sentido, ele contrasta a biopolítica - enquanto tecnologia política - com os mecanismos de disciplina que ele analisou em Vigiar e punir:

"Estes dois mecanismos (disciplina e biopolítica), portanto, se complementam e operam conjuntamente, em torno de um elemento que se aplica a um e a outro, que é precisamente a 'norma', que é o elemento fundamental de caracterização de uma 'sociedade de normalização'. Assim, a 'sociedade de normalização' não é uma 'sociedade disciplinar generalizada', em que todos os espaços teriam sido recobertos somente pela disciplina; como diz Foucault, 'a sociedade de normalização é uma sociedade em que se cruzam, conforme uma

\footnotetext{
${ }^{142}$ FERRAZ JR, Tercio Sampaio. Estudos de filosofia do direito: reflexões sobre o poder, a liberdade, a justiça e o direito. 3. ed. São Paulo: Atlas, 2009, p. 9.

${ }^{143}$ FOUCAULT, Michel. Microfísica do poder. Tradução de Roberto Machado. Rio de Janeiro: Edições Graal, 1979, p. 186.

144 "Este novo tipo de poder, que não pode mais ser transcrito nos termos da soberania, é uma das grandes invenções da sociedade burguesa. Ele foi um instrumento fundamental para a constituição do capitalismo industrial e do tipo de sociedade que lhe é correspondente; este poder não soberano, alheio à forma da soberania, é o poder disciplinar”. FOUCAULT, Michel. Microfísica do poder. Tradução de Roberto Machado. Rio de Janeiro: Edições Graal, 1979, p. 188.

${ }^{145}$ Em Foucault “... o poder vem de baixo; isto é, não há, no princípio das relações de poder, e como matriz geral, uma oposição binária e global entre os dominadores e os dominados, dualidade que repercutia de alto a baixo e sobre grupos cada vez mais restritos até as profundezas do corpo social'. Cf. Michel FOUCAULT. In: História da sexualidade I: vontade de saber. Tradução de Maria Thereza da Costa Albuquerque e J. A. Guilhon Albuquerque. 19. ed. Rio de Janeiro: Graal, 1988, p. 104.

${ }^{146}$ É nesse sentido que a instituição penal moderna não teria surgido das mudanças humanitárias do direito penal, mas consequência da sociedade reguladora e disciplinada que estava começando a surgir.

${ }_{147}$ Cf. Michel FOUCAULT. In: Em defesa da sociedade. Tradução de Maria Hermantina Galvão. São Paulo: Martins Fontes, 1999, p. 289.
} 
articulação ortogonal, a norma da disciplina e a norma da regulamentação'. A 'sociedade da normalização', assim, é aquela em que as pessoas sofrem a incidência, a partir de formas particulares, tanto da disciplina quanto do biopoder. São eles dois mecanismos de 'normalização', cada qual atuando em âmbitos diversos." 148

Se, por um lado, a disciplina preocupa-se com o corpo humano, o biopoder aplicase aos sujeitos enquanto seres viventes, é dizer, problemas de massa, muito embora a biopolítica não exclua o exercício do poder disciplinar, mas o embute, integra-o. Ambos os fenômenos resultam numa tecnologia de poder mirada na vida que, ato contínuo, resultam na emergência de uma sociedade normalizadora em detrimento do poder de morte, muito embora a disciplina trabalhe no corpo dos indivíduos e o biopoder na esfera dos seres viventes. Para RICARDO MARCELO FONSECA, a disciplina:

“... é uma forma não necessariamente regulamentada (juridicamente) e não está calcada numa relação de legitimidade com o ato fundador e originário do aparecimento do poder. É um poder local, que se exerce de modo capilar, e não de modo maciço e homogêneo, e que não se pode apreender a partir dos seus níveis de intenção ou de decisão - já que as intenções (se intenções houver) estão ligadas às práticas efetivas, nas instâncias materiais de sujeição. O indivíduo, aqui não é um núcleo elementar ou um átomo primitivo no qual o poder se aplica e submete, mas é ele o próprio (o indivíduo) um dos efeitos do poder, já que o poder transita pelo indivíduo e o constitui." 149

Para Foucault, consequentemente, a biopolítica emprega mecanismos divergentes dos aplicáveis no exercício do poder disciplinar, porquanto as estatísticas e previsões expectativa de vida e o seu almejado equilíbrio (medicina social), exemplificativamente não podem e não devem tratar dos indivíduos, mas da generalidade associada à população.

Em comparação às técnicas do poder disciplinar, portanto, o biopoder requereu o desenvolvimento de novas técnicas e mecanismos de conhecimento visando à identificação

\footnotetext{
${ }^{148}$ FONSECA, Ricardo Marcelo. Foucault, o direito e a "sociedade de normalização". In: Crítica da modernidade: diálogos com o direito. Florianópólis: Fundação Boiteux, 2005, p. 119.

${ }^{149}$ FONSECA, Ricardo Marcelo. Op. cit., p. 116.
} 
de seus objetos e à facilitação de seu próprio exercício, ainda que permanecesse ligado às técnicas de poder exercidas sobre as pessoas, uma vez que seres vivos pertencentes às populações. Para Foucault, a biopolítica “... centrou-se no corpo-espécie, no corpo transpassado pela mecânica do ser vivo e como suporte dos processos biológicos: a proliferação, os nascimentos e a mortalidade, o nível de saúde, a duração da vida, a longevidade, com todas as condições que podem fazê-los variar; tais processos são assumidos mediante toda uma série de intervenções e controles reguladores: uma biopolítica da população" ${ }^{, 150}$.

Exempli gratia, ele entende que a modernidade viu o desenvolvimento da polícia estatal diretamente relacionada ao controle de natalidade e meio ambiente - notadamente quanto às condições da vida urbana -, e à taxa de crescimento da população, bem como ao problema da morbidade, acidentes, anomalias e doenças endêmicas numa determinada população, fenômeno esse que deu consequente azo a políticas públicas de higiene e saneamento básico.

Ou seja, na tese foucaultiana, há definitivamente uma clara distinção entre representação e técnicas do poder, isto é, a assimetria por ele apontada baseia-se no nível da prática e do efetivo exercício do poder e não no nível da representação. É nesse cenário que emerge a discussão do novo corpo biopolítico agambeniano.

\subsubsection{O novo corpo biopolítico}

Na visão de Agamben, a chave para a compreensão do fenômeno político moderno igualmente repousa, assim como entende Foucault, no seu caráter biopolítico. Contudo, essa compreensão tem uma concepção distinta - ou além - da exteriorizada pelo filósofo francês.

Metodologicamente, Agamben apresenta sua tese preocupando-se com a figura da vida nua - acrescenta-se, portanto, uma nova característica semântica de vida no debate biopolítico - como uma correção de alguns pontos noticiados por Foucault e, ao mesmo tempo, como um complemento do pensamento deste.

\footnotetext{
${ }^{150}$ FOUCAULT, Michel. História da sexualidade: a vontade de saber. Tradução de Maria Thereza da Costa Albuquerque e J. A. Guilhon Albuquerque. 19. ed. Rio de Janeiro: Graal, 1988, p. 131.
} 
A correção de Foucault, para Agamben, consiste justamente na assertiva de que a entrada da vida nua na esfera dos mecanismos políticos e do exercício do poder soberano não envolveu uma radical transformação das categorias político-filosóficas, ou seja, independe da emergência da biopolítica como ápice do desenvolvimento das técnicas modernas do poder estatal ${ }^{151}$.

Pelo contrário, Agamben argumenta que a inclusão da vida nua no âmbito político é o núcleo originário do poder soberano, de maneira que a produção de um corpo biopolítico é a própria atividade originária do poder soberano. Biopoder não produz vida, nem morte, mas vida nua, mera sobrevivência exposta à morte. Por essa razão, a “... biopolítica é, nesse sentido, pelo menos tão antiga quanto a exceção soberana" ${ }^{152}$ (antica almeno quanto l'eccezione sovrana), e não um limiar da modernidade. A emergência da vida nua, assim, teria sido somente intensificada, de acordo com WILLIAM CONNOLLY ${ }^{153}$ - trazida à luz, mas não criada - na modernidade, de modo que "são os corpos absolutamente matáveis dos súditos que formam o novo corpo biopolítico" ${ }^{\text {154 }}$.

\footnotetext{
151 "In contrast to Foucault, for whom biopower represents a shift in paradigm, Agamben maintains that the inclusion of bare life within the political order is absolutely ancient; what makes the current situation noteworthy is the degree to which the realm of bare life has come to coincide with politics proper. Sovereign power has always placed biological life at its center only now the modern state has made this explicit, rendering the distinction between the human and the citizen, between fact and right, all but indistinguishable". DECAROLI, Steven. Boundary stones: Giorgio Agamben and the field of sovereignty. In: CALARCO, Matthew; DECAROLI, Steven (ed.). Giorgio Agamben: sovereignty and life. Stanford, California: Stanford University Press, 2007, p. 53.

${ }^{152}$ AGAMBEN, Giorgio. Homo sacer: o poder soberano e a vida nua I. Tradução de Henrique Burigo. Belo Horizonte: Editora UFMG, 2002, p.14.

153 "Biocultural life has been intensified today with the emerge of new technologies of infusion. But the shift is not as radical as Agamben makes it out to be. In late-modern life, new technologies enable physicians, biologists, geneticists, prision systems, advertisers, media talking heads, and psychiatrists to sink deeply into human biology. They help to shape the cultural being of biology, although not always as they intend to do. Agamben's review of new medical technologies to keep people breathing after their brains have stopped functioning captures something of this change, showing why a sovereign authority now has to decide when death has arrived rather than letting that outcome express the slow play of biocultural tradition. Numerous such judgments, previously left to religious tradition in predominantly Christian cultures, have now become explicit issues of technology and sovereignty in religiously diverse states". CONNOLLY, William E. The complexities of sovereignty. In: CALARCO, Matthew; DECAROLI, Steven (ed.). Giorgio Agamben: sovereignty and life. Stanford, California: Stanford University Press, 2007, p. 30.

${ }^{154}$ AGAMBEN, Giorgio. Homo sacer: o poder soberano e a vida nua I. Tradução de Henrique Burigo. Belo Horizonte: Editora UFMG, 2002, p.131.
} 
É nesse sentido que ANTON SCHÜTZ lança uma interessante questão: já teria existido uma era antes do homo sacer ${ }^{155}$ ? Para ele, essa pergunta revela uma nítida divergência entre Foucault e Agamben. Enquanto Foucault outorga à emergência da biopolítica uma data - a própria modernidade, ou melhor, um nascimento da modernidade , nada em Agamben oferece esse fio-condutor. Não há uma sequência de eras cronológicas até mesmo porque, como será analisado abaixo, o estado de exceção é inerente não somente à origem de qualquer poder soberano, à pólis grega e à civitas romana, mas igualmente à fundação da própria cidade moderna.

Já o complemento da tese foucaultiana, por sua vez, repousa na maneira como a vida nua foi originalmente inserida no âmago político: numa relação de abandono que une vida nua e soberania, isto é, numa esclusione inclusiva (ex-capere) ${ }^{156}$, em que aquilo que é excluído da proteção da lei mantém com esta uma relação extralegal de internamento.

Dessa maneira, Agamben sugere que a figura característica da modernidade não é a emergência da biopolítica - um fenômeno que, para Foucault, estava originalmente situado às margens da ordem política e que passaria a coincidir com a própria política na era moderna -, mas o reconhecimento de que a biopolítica, em seu sentido originário, precede e se identifica com a política moderna por meio de uma exclusão inclusiva.

De fato, no desenvolvimento de sua análise crítica da tese foucaultiana sobre biopolítica e soberania - e, por conseguinte, exceção -, Agamben faz uma relevante distinção na conceituação metodológica do biopoder: para Foucault, ela parece ser histórica, enquanto Agamben se envereda pela ontologização ${ }^{157}$ do político, como, por exemplo, em sua insistente discussão do problema metafísico da potencialidade como o próprio problema político da soberania ${ }^{158}$.

${ }^{155} \mathrm{Cf}$. Anton SCHÜTZ. In: The fading memory of homo non sacer. In: CLEMENS, Justin; HERON, Nicholas; MURRAY, Alex (ed.). The work of Giorgio Agamben: law, literature, life. Edinburg University Press, 2008, p. 114.

${ }^{156}$ A figura da exclusão inclusiva será investigada com mais vagar abaixo, de modo que, por ora, basta termos em mente que a figura do banimento, que está na fonte da soberania, é a relação política originária que reduz o vínculo social à vida nua.

${ }_{157}$ A herança de Agamben não é somente a ênfase nas relações da violência prática e normalizadora que formam a idéia de Foucault, mas preocupações ontológicas analisadas, exemplificativamente, por Aristóteles e Martin Heidegger.

${ }^{158}$ Cf. Catherine MILLS. In: Biopolitics, liberal eugenics, and nihilism. In: CALARCO, Matthew; DECAROLI, Steven (ed.). Giorgio Agamben: sovereignty and life. Stanford, California: Stanford University Press, 2007, p. 180. 
Enquanto a genealogia de Foucault parece não se preocupar com a busca pelo sentido originário e desenvolve a hegemonia de um poder desprovido de centro, disseminado e horizontal, Agamben procura justamente iluminar a relação originária entre lei e vida por meio da estrutura da exceção do poder soberano. Agamben parece negar em termos Foucault - ou melhor, corrige-o e o integra - e determina que a relação entre lei e vida dá-se, como sempre se deu, por meio dessa estrutura. VlaDiMIR SAFATLE definiu a relação entre Agamben e Foucault em termos de quão longe e quão perto:

“Quão longe porque Agamben não está disposto a continuar com as distinções foucaultianas estritas entre poder soberano e poder disciplinar... Agamben, no entanto, quer mostrar esta implicação orgânica entre poder soberano, modos de subjetivação e gestão calculista da vida que nos leva diretamente às estruturas fundamentais do biopoder moderno. Ele quer insistir no vínculo entre exceção, ou seja, entre modo de funcionamento do ordenamento jurídico na modernidade e uma vida que é, cada vez mais, vida nua submetida a uma estranha 'lógica disciplinar de anomia'... Quão perto porque vem de Foucault esta procura pela 'possibilidade de uma ação humana que se situe fora de toda relação com o direito', ação capaz de nos abrir a um uso renovado do mundo.",159

Por essas mesmas razões, a visão de Agamben, ao colocar a vida nua no centro de seus cálculos - reconduzindo à luz o verdadeiro vínculo secreto que a une ao poder -, é também comprometida com o trabalho de Walter Benjamin, de um lado, e o de Carl Schmitt, de outro lado ${ }^{160}$, até mesmo porque Benjamin oferece os recursos teóricos para se pensar além do estado de exceção articulado por Schmitt em sua tese decisionista da soberania.

Por conseguinte, a conceituação que Agamben confere à vida nua talvez seja o ponto mais relevante para aqueles que pretendam diagnosticar a condição biopolítica

\footnotetext{
159 SAFATLE, Vladimir. Materialismo, imanência e política: sobre a teoria da ação de Giorgio Agamben. In: SEDLMAYER, Sabrina; GUIMARÃES, César; OTTE, Georg. O comum e a experiência da linguagem. Belo Horizonte: Editora UFMG, 2007, p. 106.

${ }^{160}$ A bem da verdade, o fiocondutor da tese agambeniana pode ser igualmente entendido como uma tentativa de completar a crítica de Benjamin à teoria da soberania de Schmitt, ao lado da crítica à Foucault.
} 
contemporânea de acordo com seu trabalho. Por essa razão e tendo em mente que a relação entre biopolítica, soberania e exceção será investigada particularmente abaixo (tentamos, neste momento, centralizar nosso estudo na politização da vida, muito embora os temas corriqueiramente se sobreponham), discorreremos a seguir sobre as várias noções de vida que Agamben propõe e o papel delas em sua teoria biopolítica.

\subsubsection{A vida nua}

Com efeito, a tese de Agamben quanto ao caráter biopolítico essencial da política Ocidental, ainda que partindo de Foucault, repousa no argumento de que a atividade fundamental do poder soberano é a produção da vida nua ${ }^{161}$ (nuda vita, nackte leben ou bloss leben, vie nue ou, ainda, bare life ou naked life ${ }^{162}$ ), o cultivo de uma criatura humana como o elemento político originário e o limite da articulação entre natureza e cultura, entre zoé e bios.

Afinal, qual o significado de vida nua? Agamben apresenta esse termo no contexto de seus comentários de Foucault, bem como na distinção entre bios e zoé estruturada por Aristóteles $^{163}$. E não poderia ser de outra forma, uma vez que Agamben não raramente remete-se ao pensamento de Wittgenstein, para quem os problemas filosóficos tornam-se mais claros se eles forem formulados como questões acerca do significado das palavras. Ao tratar da etimologia da palavra vida, Agamben sublinha exaustivamente que os gregos tinham dois termos semanticamente distintos: zoé, que revela o simples fato da vivência

\footnotetext{
${ }^{161}$ Catherine MILLS esclarece o papel fundamental da vida nua no trabalho de Agamben: "Agamben's conception of bare or naked life ("nuda vita") has perhaps been one of the most productive for those wanting to use his work as a diagnosis of contemporary political conditions. For instance, it has been used as a tool for understanding phenomena as diverse as the international legal status of refugees, suicide bombers, and the social status of poverty-stricken HIV sufferers of Brazil among others". In: The philosophy of Agamben. McGill-Queen's University Press, 2008, p. 69.

${ }^{162}$ Para a opção da tradução de la nuda vita ao inglês como naked life ou bare life, vide Nota do Tradutor ao Prefácio in AGAMBEN, Giorgio. Means without end: notes on politics. Tradução Vincenzo Binetti e Cesare Casarino. Minneapólis: University of Minnesota Press, 2000.

${ }^{163}$ Segundo Agamben: "It is important to observe that Aristotle in no way defines what life is: he limits himself to breaking it down, by isolating the nutritive function, in order to rearticulate it in a series of distinct and correlated faculties (nutrition, sensation, thought). In De anima, as well as in the Nicomachean Ethics and the Politics, nutritive life (or vegetative life, as it will be called as early as the ancient commentators, on the basis of that peculiar, obscure status as absolutely separated from logos that plants constantly have in Aristotle's thought) is that on the exclusion of which the definition of man, that is, of the living being that has logos, is founded." In: The work of man. In: CALARCO, Matthew; DECAROLI, Stevens (ed.). Giorgio Agamben: sovereignty and life. Stanford, California: Stanford University Press, 2007, p. 4.
} 
inerente a qualquer ser vivente - animais, homem ou deuses à época ${ }^{164}$-, ou, ainda, a vida na ô̂kos; e bios, que indica a forma ou caminho apropriado de se viver para um indivíduo ou grupo, quer dizer, uma vida qualificada ou, ainda, a vida na esfera da pólis ${ }^{165}$.

Com essa distinção em mente, poderíamos concluir que a concepção de Foucault de biopolítica sinaliza na verdade não a entrada da vida, no sentido generalizado, na política, mas sim a integração do que é capturado pela designação mais especifica de zoé ou vida natural. O que está em jogo na política moderna, de acordo com Foucault, é o simples corpo vivente do individuo e da espécie, é dizer, a inserção da vida natural do governado nos cálculos do poder estatal, tornando-se objeto de especificas técnicas de governo.

Por outras palavras, na visão de Foucault, parece-nos que a emergência da biopolítica refere-se à entrada da zoé, enquanto vida biológica, na esfera da pólis, ou seja, à politização da vida natural ${ }^{166}$. Isso se deve porque, como bem notado por Agamben, a distinção qualitativa feita por Aristóteles entre vida biológica e vida política efetivamente excluiu vida natural da pólis no estrito sentido e a relegou inteiramente à esfera privada, como a vida básica de reprodução e administração da casa.

Entretanto, Agamben imediatamente problematiza a questão apontando que o protagonista de sua teoria não é a vida natural, mas a vida nua. Para Agamben, a vida nua é o corpo biopolítico da modernidade: "Não a simples vida natural, mas a vida exposta à morte (a vida nua ou a vida sacra) é o elemento político originário" ${ }^{167}$ (Non la semplice vita naturale, ma la vita esposta alla morte (la nuda vita o vita sacra) è l'elemento politico originario). Explica-se: a vida nua não é a simples vida natural, mas sim a vida natural de um determinado indivíduo capturada numa relação particular com o poder que o segrega do divino e do profano. Não é bios nem zoé, mas sim a forma politizada da vida natural ${ }^{168}$ exposta soberanamente à morte. Mas por que exposta à morte?

\footnotetext{
${ }^{164}$ Segundo Agamben, destarte, essa vida era meramente reprodutiva e, portanto, confinada ao âmbito do oîkos. Ainda que zoé fosse considerada um bem, não teria feito sentido uma zoé politiké dos cidadãos de Atenas. A zoé não pertencia à pólis. Cf. Giorgio AGAMBEN. In: Homo sacer: o poder soberano e a vida nua I. Tradução de Henrique Burigo. Belo Horizonte: Editora UFMG, 2002, p. 9.

${ }^{165}$ Cf. Giorgio AGAMBEN. In: Homo sacer: o poder soberano e a vida nua I. Tradução de Henrique Burigo. Belo Horizonte: Editora UFMG, 2002, p. 9.

${ }^{166}$ Cf. Paul PATTON. Op. cit., p. 210.

167 AGAMBEN, Giorgio. Homo sacer: o poder soberano e a vida nua I. Tradução de Henrique Burigo. Belo Horizonte: Editora UFMG, 2002, p. 96.

${ }^{168}$ Assim, "Toda tentativa de repensar o espaço politico do Ocidente deve partir da clara consciência de que da distinção clássica entre zoé e bíos, entre vida privada e existência política, entre homem como simples
} 
Do mesmo modo que a vida apareceu no direito romano como contraparte de um poder do pater que ameaça com a morte - à luz da fórmula vitae necesque potestas -, o “imperium do magistrado nada mais é que a vitae necisque potestas do pai estendida em relação a todos os cidadãos" ${ }^{169}$. COLIN MCQUILAN comenta essa linha de raciocínio agambeniana:

"Because Agamben says the original meaning of sacer is 'doomed to death', he will locate the sovereign right 'to let live and let die' in sacrifice - in this 'sacrum facere'. In Homo Sacer, Agamben explains this with reference to the archaic Roman vitae necisque potestas, the absolute right of the father over the life and death of his sons. This is the power that makes the pater - the father domus - head of the household, dominator. Here, life - vita, zoé - is only a correlate of the power to kill - nex. It is what the law presupposed in granting the father his right - there must be something for him to kill, namely, the life of his sons. And because the Romans thought there to be 'essential affinity' between this right and the power of imperium, exercised by the sovereign, man - as citizen, as bios politikos - was subject to sovereign decision regarding life and death, just as were the father's sons. Here, man becomes homo sacer, sacred life - but this is simply life that can be killed."170

Destarte, segundo Agamben, “... não se poderia dizer de modo mais claro que o fundamento primeiro do poder político é uma vida absolutamente matável, que se politiza através de sua própria matabilidade"171. Imediatamente politizada, mas, no entanto, excluída da pólis numa exclusão inclusiva, vida nua é o conceito-limite entre pólis e ô̂kos. E, sendo o que é capturado pela figura do banimento soberano ${ }^{172}$, vida nua indica a exposição da vida natural à força de lei no abandono, a última expressão do que é o poder

vivente, que tem seu lugar na casa, e o homem como sujeito político, que tem seu lugar na cidade, nós não sabemos mais nada." AGAMBEN, Giorgio. Homo sacer: o poder soberano e a vida nua I. Tradução de Henrique Burigo. Belo Horizonte: Editora UFMG, 2002, p. 193.

${ }^{169}$ AGAMBEN, Giorgio. Homo sacer: o poder soberano e a vida nua I. Tradução de Henrique Burigo. Belo Horizonte: Editora UFMG, 2002, p. 96.

${ }^{170}$ MCQUILLAN, Colin. The political life in Giorgio Agamben. Kritikos, v. 2, July 2005. Disponível em http://garnet.acns.fsu.edu/ nr03/mcquillan.htm. Acessado em 22.10.2007.

${ }^{171}$ AGAMBEN, Giorgio. Homo sacer: o poder soberano e a vida nua I. Tradução de Henrique Burigo. Belo Horizonte: Editora UFMG, 2002, p. 96.

${ }^{172}$ A figura do banimento e o veto ao sacrifício daquele que porta a vida nua - o homo sacer - serão examinados particularmente abaixo. 
soberano do direito à morte. Assim, nem bios, nem zoé, vida nua emerge por meio de uma exposição irreparável da vida à morte no banimento soberano, quer dizer, infinitamente exposta à violência soberana.

É, portanto, a exposição a essa violência que marca a vida nua como uma indistinção entre dentro e fora da ordem política, ou uma excrescência produzida a partir da divisão da vida biológica e da vida política. "Nem bios político nem zoé natural, a vida sacra é a zona de indistinção na qual, implicando-se e excluindo-se um ao outro, estes constituem mutuamente" ${ }^{, 173}$.

De fato, como veremos abaixo, uma vez que a inclusão da vida na lei é somente possível por meio da estrutura excepcional que suspende a própria lei, a vida é somente incluída por meio de sua própria exclusão. Isso significa que a vida pode, em última análise, ser inserida na esfera da lei somente por meio da pressuposição de sua própria esclusione inclusiva.

Desse modo, vida nua é a existência biológica sujeita a uma condição particular de exclusão inclusiva do domínio soberano. Para PAUL PATTON, “... for the purposes of the argument with Foucault, bare life is not simple natural life but rather life endowed with a peculiar status that is achieved by the subjection of an individual life to sovereign power, albeit in the form of an exclusion from the protection otherwise afforded by the sovereign" ${ }^{\prime 174}$. Em outras palavras, é a vida do homo sacer ${ }^{175}$.

É com esse embasamento que Agamben pretende corrigir a tese foucaultiana no sentido de que a zoé sempre esteve na pólis por meio de sua exclusão inclusiva. Aquilo que caracteriza a política moderna “... não é tanto a inclusão da zoé na polis, em si antiguíssima, nem simplesmente o fato de que a vida como tal venha a ser um objeto eminente dos cálculos e das previsões do poder estatal" ${ }^{\text {176 }}$. Ou seja, Agamben, revisando o

\footnotetext{
${ }^{173}$ AGAMBEN, Giorgio. Homo sacer: o poder soberano e a vida nua I. Tradução de Henrique Burigo. Belo Horizonte: Editora UFMG, 2002, p. 98.

${ }^{174}$ PATTON, Paul. Op. cit., p. 211.

${ }^{175}$ A vida nua continua, assim, presa à política sob a forma de exceção, isto é, de alguma coisa que é incluída somente por meio de uma exclusão. $O$ estado de exceção passa a ser a base até então apócrifa sobre a qual se assenta o sistema político. Aqui damos início finalmente à conexão do objeto desta dissertação e todo o quanto já relatado.

${ }^{176}$ AGAMBEN, Giorgio. Homo sacer: o poder soberano e a vida nua I. Tradução de Henrique Burigo. Belo Horizonte: Editora UFMG, 2002, p. 16.
} 
pensamento de Foucault, insiste que a vida nua do indivíduo esteve sempre no coração do poder soberano: "a vida nua tem, na política ocidental, este singular privilégio de ser aquilo sobre cuja exclusão se funda a cidade dos homens"177.

Isso revela, portanto, que biopolítica e soberania no pensamento agambeniano são original e fundamentalmente interligadas: nas palavras do filósofo italiano, “... o soberano entra em simbiose cada vez mais íntima não só com o jurista, mas também com o médico, com o cientista, com o perito, com o sacerdote" ${ }^{, 178}$. De tal modo, a política moderna não representa uma quebra definitiva da clássica soberania, mas, ao contrario, obriga a extensão e a generalização do estado de exceção que funda o poder soberano.

É nesse sentido que Agamben discorre que não se trata do fazer morrer e deixar viver do velho poder soberano, nem do fazer viver e deixar morrer do biopoder, mas "já não fazer morrer, nem fazer viver, mas fazer sobreviver" "179 (a questão da sobrevivência ficará mais nítida ao tratarmos do homo sacer e do campo moderno).

Porém, não podemos deixar de criticar o conceito de vida nua que é, até mesmo, frequentemente confundido com a vida natural. Em parte, isso se deve porque o próprio Agamben às vezes - ou muitas vezes - usa o termo vida nua como referencia à vida natural $^{180}$. Essa confusão pode ser atribuída, contudo, ao fato de que há diversas formas de vida na democracia contemporânea para esse filósofo.

Numa análise superficial, poder-se-ia, em algumas ocasiões, qualificar a vida nua como a vida natural ou biológica dos seres humanos ${ }^{181}$. Mas, nesse sentido, não haveria razão para não se adequar o conceito ao surgimento da biopolítica no pensamento de Foucault.

\footnotetext{
${ }^{177}$ AGAMBEN, Giorgio. Homo sacer: o poder soberano e a vida nua I. Tradução de Henrique Burigo. Belo Horizonte: Editora UFMG, 2002, p. 15.

${ }^{178}$ AGAMBEN, Giorgio. Homo sacer: o poder soberano e a vida nua I. Tradução de Henrique Burigo. Belo Horizonte: Editora UFMG, 2002, p. 128.

${ }^{179}$ Cf. Giorgio AGAMBEN. O que resta de Auschwitz: o arquivo e a testemunha. Tradução de Selvino J. Assmann. São Paulo: Boitempo, 2008, p. 155.

${ }^{180}$ PAUL PATTON elucida que, exemplificativamente, "While in the context of his analysis of sovereignty, 'bare life' is identified with the sacred life or status of homo sacer, in the context of his critical remarks about modern democratic societies, he identifies it with the natural life of zoé". Op. cit., p. 211.

${ }^{181}$ Ao considerarmos a vida nua mero sinônimo de vida natural, a rejeição de Agamben à tese do sacrifício e da sacralização da vida em sua frequente pretensão de uma nova forma-de-vida tornar-se-ia opaca.
} 
De fato, se Foucault entende que a vida do indivíduo já era integralmente abraçada na esfera do poder soberano antes do advento da biopolítica, ainda que por meio do direito de morte, já não existiria então uma biopolítica antes mesmo da modernidade? Haveria aqui uma aparente identidade, ainda que em termos, com a tese de Agamben. Há realmente uma pontual convergência, pois nos parece que a análise de Foucault da clássica soberania antecipa sim a tese de Agamben, no sentido de que a vida biológica dos sujeitos esteve sempre incluída dentro do campo do poder soberano.

Muito embora a teoria foucaultiana não discuta a figura do homem sagrado que é ao mesmo tempo excluído da proteção das ordens política e divina, a sugestão de Foucault de que o sujeito do poder soberano é neutro com relação à vida e à morte implica a possibilidade de retirada desse estado e, com isso, sua exclusão da esfera do poder soberano. Em outras palavras, resultaria ao mesmo tempo na exposição da figura exilada à perda da proteção de sua vida e à liberdade da ameaça de morte nas mãos do soberano e, portanto, poderíamos asseverar que, estruturalmente, a vida do sujeito sob a teoria clássica da soberania, segundo a definição de Foucault, é similar à figura da vida nua do homo sacer: é existência biológica duplicada por sua exclusão inclusiva na esfera política $^{182}$.

Nesse sentido, a análise de Foucault do direito soberano clássico não precisaria de correção, como pretende Agamben. Se considerarmos vida nua como mera vida biológica, ou zoé, então essa análise já é consistente com a reivindicação de Agamben de que a vida nua e a possibilidade de seu banimento sempre constituíram a estrutura essencial do poder soberano. No nível da representação, soberania clássica já seria, assim, biopoder.

As particularidades da vida nua enquanto figura inerente ao homo sacer na exclusão inclusiva do estado de exceção, assim como a relação de banimento e a nova forma-devida serão analisada abaixo, de modo que, por ora, é suficiente termos em mente que, para Agamben, “... nós não somos apenas, nas palavras de Foucault, animais em cuja política está em questão suas vidas de seres viventes, mas também, inversamente, cidadãos em cujo corpo natural está em questão a sua própria política"183 (E noi non siamo soltanto, nelle parole di Foucault, degli animali nella cui politica è in questione la loro vita di esseri

\footnotetext{
${ }^{182}$ Cf. Paul PATTON. Op. cit., p. 214.

183 AGAMBEN, Giorgio. Homo sacer: o poder soberano e a vida nua I. Tradução de Henrique Burigo. Belo Horizonte: Editora UFMG, 2002, p. 193.
} 
viventi, ma anche, inversamente, dei cittadini nel cui corpo naturale è in questione la loro stessa politica).

\subsubsection{Biopolítica e totalitarismo moderno}

É sob esse ponto de partida que Agamben lança algumas conclusões relacionadas à essência biopolítica da era moderna ${ }^{184}$, inclusive e principalmente a zona de indistinção que une - não tanto na esfera empírica, mas na filosófica -, em seu pensamento, democracia liberal e totalitarismo moderno.

Para o pensador italiano, modelos político-governamentais de ambas as naturezas democrática e totalitária -, são fundados na vida nua de seus sujeitos: a exceção da vida nua é o motor invisível da modernidade. E, nessa condição, “... distinções políticas tradicionais (como aquelas entre direita e esquerda, liberalismo e totalitarismo, privado e público) perdem clareza e sua inteligibilidade" ${ }^{\text {185 }}$. Ou seja, perdem sua própria razão de ser, porquanto advindas justamente de uma referência fundamental em comum - a vida nua -, adentrando forçosamente numa zona de indistinção.

Nessa toada, a famosa Déclaration des droits de l'homme et du citoyen de $1789^{186}$, que, pode-se dizer, teria inaugurado a era da política moderna, para Agamben teria simplesmente trazido à luz a vida nua - que já era figura originária da política para Agamben, repita-se ${ }^{187}$ - dos sujeitos como fundação da soberania dos Estados-nação, como bem elucida JENNY EDKINS ${ }^{188}$. Se a passagem de súdito a cidadão marca o surgimento de um reconhecível governo moderno, Agamben declara que a política Ocidental é

\footnotetext{
${ }^{184}$ Para Dominick LACAPRA, “... Agamben has a general conception of the modern age as one tending toward or even embodying the combination of sovereignty and mere, bare, or naked life of unlimited power and the reduction of the human being to a being denuded of possibilities and in a condition of ultimate abjection". Op. cit., p. 137.

${ }^{185}$ AGAMBEN, Giorgio. Homo sacer: o poder soberano e a vida nua I. Tradução de Henrique Burigo. Belo Horizonte: Editora UFMG, 2002, p. 128.

${ }^{186} \mathrm{Cf}$. Giorgio AGAMBEN. In: We refugees. Translated by Michael Rocke. The European Graduate School. Disponível em http://egs.edu/faculty/agamben/agamben-we-refugees.html. Acessado em 20.10.2007.

${ }_{187}$ Para Agamben, “... o rio da biopolitica, que arrasta consigo a vida do homo sacer, corre de modo subterrâneo, mas contínuo". In: AGAMBEN, Giorgio. Homo sacer: o poder soberano e a vida nua I. Tradução de Henrique Burigo. Belo Horizonte: Editora UFMG, 2002, p. 127.

188 "Crucial to the whole process, and to its apparent unassailability, is the way in which bare life or homo sacer is both the object of sovereign power and the subject of democratic attempts to hold that power to account, first through citizens' rights and democratic accountability, then through human rights and humanitarianism. This means that humanitarianism and sovereignty, to pick on one pairing as example, share a 'secret solidarity". EDKINS, Jenny. Whatever Politics. In: CALARCO, Matthew; DECAROLI, Steven (ed.). Giorgio Agamben: sovereignty and life. Stanford, California: Stanford University Press, 2007, p. 75.
} 
originariamente uma biopolítica, de maneira que a transição da soberania clássica para a política democrática moderna não é tanto uma liberação dos ex-súditos, porquanto seu aprisionamento repousa no âmago próprio do poder biopolítico de que tentam escapar.

Seu aprisionamento repousa não somente nos campos de concentração do nacionalsocialismo ${ }^{189190}$, sua solução final (Endloesung) e seus programas visando ao extermínio de indivíduos geneticamente desqualificados ou portadores de doenças incuráveis, ainda que não-judeus, mas igualmente na maneira pela qual, a título de exemplo, os próprios estados democráticos usam seus prisioneiros e/ou sua população marginal para recorrentes intervenções e experiências biomédicas no organismo humano ${ }^{191}$ - ainda que na tentativa de utilizar as ciências biológicas para melhorar a qualidade de vida, de maneira a garantir a melhor sobrevivência da humanidade -, levantando a questão da bioética, principalmente porque “... no horizonte biopolítico que caracteriza a modernidade, o médico e o cientista movem-se naquela terra de ninguém onde, outrora, somente o soberano podia penetrar" ${ }^{\prime 192}$. De fato, como leciona a italiana CARLA FARALLI, a pesquisa no âmbito médico e, mais em geral, no âmbito científico, permite possibilidades cada dia maiores de

189 “... entre as primeiras leis expedidas pelo regime nacional-socialista, figuram justamente aquelas que concernem à eugenética. Em 14 de julho de 1933, poucas semanas após a ascensão de Hitler ao poder, foi promulgada a lei para a 'prevenção da descendência hereditariamente doente', que estabelecia que 'aquele que se encontra afetado por uma doença hereditária pode ser esterilizado com uma operação cirúrgica se existe alta probabilidade, segundo a experiência da ciência médica, que os seus descendentes sejam afetados por graves perturbações hereditárias do corpo ou da mente”. AGAMBEN, Giorgio. Homo sacer: o poder soberano e a vida nua I. Tradução de Henrique Burigo. Belo Horizonte: Editora UFMG, 2002, p. 155.

${ }^{190}$ Quanto aos VP (Versuchepersonen, cobaias humanas), Agamben exterioriza que "No processo de Nuremberg, os experimentos conduzidos pelos médicos e pesquisadores alemães nos campos de concentração foram universalmente considerados como um dos capítulos mais infames na história do regime nacional-socialista. Além daqueles sobre o salvamento a grandes alturas, em Dachau foram executados experimentos (destinados também estes a tornar possível o salvamento de marinheiros e aviadores caídos no mar) sobre a possibilidade de sobreviver em água gelada e sobre a potabilidade da água do mar". Cf. Giorgio AGAMBEN. In: Homo sacer: o poder soberano e a vida nua I. Tradução de Henrique Burigo. Belo Horizonte: Editora UFMG, 2002, p. 162.

191 "Decididamente mais embaraçosa é, além disso, a circunstância (que resulta de forma inequívoca da literatura científica anexada pela defesa e confirmada pelos peritos do tribunal) de que experimentos com detentos e condenados à morte haviam sido conduzidos muitas vezes em larga escala, no nosso século [século XX], em particular nos próprios Estados Unidos (o país de onde provinha a maior parte dos juízes de Nuremberg). Assim, nos anos vinte, oitocentos detentos nos cárceres dos Estados Unidos haviam sido infectados com o plasmódio da malária na tentativa de encontrar um antídoto para o paludismo. Exemplares, na literatura científica sobre a pelagra, eram considerados os experimentos conduzidos por Goldberger em 12 detentos estadunidenses condenados à morte, aos quais tinha sido prometido, se sobrevivessem, um indulto de pena. Fora dos USA, as primeiras pesquisas com culturas do bacilo do beribéri haviam sido conduzidas por Strong, em Manila, em condenados à morte (os protocolos dos experimentos não mencionam se tratavam-se ou não de voluntários). A defesa citou ainda o caso do condenado à morte Keanu (Havaí), que havia sido infectado com lepra sob a promessa de graça e tinha falecido em conseqüência do experimento". AGAMBEN, Giorgio. Homo sacer: o poder soberano e a vida nua I. Tradução de Henrique Burigo. Belo Horizonte: Editora UFMG, 2002, p. 164.

${ }^{192}$ AGAMBEN, Giorgio. Homo sacer: o poder soberano e a vida nua I. Tradução de Henrique Burigo. Belo Horizonte: Editora UFMG, 2002, p. 166. 
dominar a natureza - fecundação artificial, transplantes de órgãos, clonagem, etc. -, gerando lancinantes interrogações concernentes aos limites da intervenção sobre a vida humana e não-humana numa democracia contemporânea ${ }^{193}$.

Esses e outros eventos, para Agamben, confirmam que tanto o totalitarismo que floresceu no século XX, como o Estado democrático, permanecem aprisionados num horizonte circunscrito pela convergência da vida biológica e da vida política ${ }^{194}$. Para Agamben, particularmente nas democracias ${ }^{195}$ o poder sem forma e a presença fantasmagórica da polícia - nos moldes benjaminianos, que serão revistos abaixo - dá testemunho à maior forma concebível de degeneração da violência:

"Esse deslocamento de uma medida provisória e excepcional para uma técnica de governo ameaça transformar radicalmente - e, de fato, já transformou de modo muito perceptível - a estrutura e o sentido da distinção tradicional entre os diversos tipos de constituição. O estado de exceção apresenta-se, nessa perspectiva, como um patamar de indeterminação entre democracia e absolutismo."196

Agamben parece crer que a democracia, tal como exercida atualmente, falhou na sua tarefa principal de promover a amenidade da vida, de modo que “...o campo é o próprio paradigma do espaço político no ponto em que a política torna-se biopolítica e o

\footnotetext{
${ }^{193}$ FARALLI, Carla. A filosofia contemporânea do direito: temas e desafios. São Paulo: Martins Fontes, 2006, p. 67.

${ }^{194}$ Adotando essa linha, os brasileiros Vitor Hugo Nicastro HONESKO, Raquel Schlommer HONESKO e Tatiane Alves BARBOSA entendem que “... o fenômeno do estado de exceção faz parte de todos os Estados modernos. Basta analisar as arbitrariedades (detenções por tempo indeterminado) promovidas em Guantânamo pelo governo dos Estados Unidos da América contra os acusados de participarem de organizações terroristas. Arbitrários também são os atos dos Estados europeus (mas, também dos Estados Unidos e da Austrália) que encerram, por tempo indeterminado, refugiados (denominados imigrantes ilegais') em Centros de Detenção. Além do mais, percebe-se também uma plenitude de poder concentrada nos órgãos de governo centrais, principalmente voltada para a luta contra o terrorismo: tem-se um vertiginoso aumento dos poderes de George W. Bush (EUA), Tony Blair (Grã-Bretanha), Berlusconi (Itália) etc. O trabalho que aqui se apresenta tem a simples intenção de mostrar as peculiaridades das conseqüencias advindas da configuração do Estado de exceção no Brasil”. Op. cit., p. 266.

${ }^{195}$ Para o brasileiro Vitor Hugo Nicastro HONESKO, em artigo sobre o homo sacer tupiniquim, “... não tem sentido se falar em democracia quando grande parte da população brasileira não possui o mínimo necessário para sua subsistência". In: O totalitarismo neoliberal e a "democracia" brasileira: a construção do homo sacer tupiniquim. In: MACEDO, Paulo Emílio Vauthier (coord.). Direito e política: anais do II Congresso Brasileiro. Curitiba: Juruá, 2005, p. 244.

${ }^{196}$ AGAMBEN, Giorgio. Estado de exceção. São Paulo: Boitempo, 2004, p. 13.
} 
homo sacer se confunde virtualmente com o cidadão" ${ }^{\text {"197 }}$. Um estado de exceção invisível que Paulo SÉRgio Pinheiro não acreditaria à época ao declarar, em 1984, quando do aniversário de 20 anos da ditadura militar brasileira, que “... ou o regime de exceção termina agora ou o Brasil chegará ao século XXI sem governo eleito. 20 anos já chega" ${ }^{\text {198 }}$. Pois o governo foi eleito e, de acordo com Agamben, ainda vivemos sob o mesmo regime, ainda que sob outras vestes. O corpo incluído na lei acentua sua própria exclusão com o corpo ausente do desaparecido político, o corpo violentado da vítima de tortura, e mantém-se hoje inscrito e marcado nas salas de tortura e nos corpos matáveis pelas balas perdidas:

"Tomar consciência dessa aporia não significa desvalorizar as conquistas e as dificuldades da democracia, mas tentar de uma vez por todas compreender porque, justamente no instante em que parecia haver definitivamente triunfado sobre seus adversários e atingido seu apogeu, ela se revelou inesperadamente incapaz de salvar de uma ruína sem precedentes aquela zoé a cuja liberação e felicidade havia dedicado todos os seus esforços."

Mas não é só. Sua veemência na existência de um presente obscuro - e um futuro ainda mais indigesto ${ }^{200}$ - vai além ao decretar que “... a decadência da democracia moderna e o seu progressivo convergir com os estados totalitários nas sociedades pósdemocráticas espetaculares (que começam a tornar-se evidentes já com Tocqueville e encontram nas análises de Debord sua sanção final) têm, talvez, sua raiz nesta aporia que marca o seu início e que a cinge em secreta cumplicidade com o seu inimigo mais aguerrido. A nossa política não conhece hoje outro valor (e, consequentemente, outro desvalor) que a vida, e até que as contradições que isto implica não forem solucionadas,

\footnotetext{
${ }^{197}$ AGAMBEN, Giorgio. Homo sacer: o poder soberano e a vida nua I. Tradução de Henrique Burigo. Belo Horizonte: Editora UFMG, 2002, p. 178.

${ }_{198}$ PINHEIRO, Paulo Sérgio. Escritos indignados: polícia, prisões e política no Estado autoritário (no 20. aniversário do regime de exceção, 1964-1984). São Paulo: Brasiliense, 1984, p. 240.

199 AGAMBEN, Giorgio. Homo sacer: o poder soberano e a vida nua I. Tradução de Henrique Burigo. Belo Horizonte: Editora UFMG, 2002. p. 180.

${ }^{200}$ Para William RASCH, "Much like Adorno and Horkheimer, on the one hand, and Heidegger, on the other, Agamben sees the trajectory of the political in the West heading inexorably toward totalitarianism or facile consumerism.". In: From sovereign ban to banning sovereignty. In: CALARCO, Matthew; DECAROLI, Steven (ed.). Giorgio Agamben: sovereignty and life. Stanford, California: Stanford University Press, 2007, p. 102.
} 
nazismo e fascismo que haviam feito da decisão sobre a vida nua o critério politico supremo, permanecerão desgraçadamente atuais." ${ }^{201}$

Ao pretender buscar a bios da $z o e^{202}$, a democracia moderna de fato falhou em Agamben, de maneira que a vida nua continua inclusa na política na forma de exceção, ou seja, como algo incluído unicamente em razão de sua exclusão. Enquanto a política moderna é jogada no nível da vida biológica, em sua tentativa de descobrir a bios da zoé, ela produz continuamente vida nua como uma excrescência de sua falha. Por conseguinte, ela impede a superação da exceção soberana e da violência que precisamente condiciona a vida nua e, até que surja uma resposta adequada, política continuará a jogar no terreno da violência e da morte.

Em sua leitura de Agamben, Slavoj ZizeK parece ir até mesmo um pouco além para refletir que não há solução política ao problema ${ }^{203}$, convidando-nos a pensar uma "post-political bio-politics"204. De fato, como saída dessa deficiência, Agamben não busca uma reforma, radicalização ou expansão do humanismo e da democracia ${ }^{205}$, mas a criação de uma nova forma-di-vita, que visa, como veremos abaixo, superar a exposição da vida nua à violência soberana ao tornar impossível, aí sim, a divisão da vida natural/nutritiva e da vida política.

Há, portanto, para que não restem dúvidas, quatro formas de vida propostas no discurso agambeniano biopolítico: zoé ou vida biológica, bios ou vida política, vida nua, ou às vezes tratada como vida sagrada, do termo original nuda vita, e uma nova forma-devida, ocasionalmente chamada de vida-feliz.

\footnotetext{
${ }^{201}$ AGAMBEN, Giorgio. Homo sacer: o poder soberano e a vida nua I. Tradução de Henrique Burigo. Belo Horizonte: Editora UFMG, 2002, p. 18.

${ }^{202}$ AGAMBEN, Giorgio. Homo sacer: o poder soberano e a vida nua I. Tradução de Henrique Burigo. Belo Horizonte: Editora UFMG, 2002, p. 17.

${ }^{203}$ Cf. Slavoj ZIZEK. In: Welcome to the desert of the real. New York: Verso, 2002b, p. 100.

204 "'Post-political' is a politics which claims to leave behind old ideological struggles and instead focus on expert management and administration, while 'bio-politics' designates the regulation of the security and welfare of human lives as its primary goal”. ZIZEK, Slavoj. Violence. New York: Picador, 2008, p. 40.

${ }^{205}$ Cf. Matthew CALARCO. Op. cit., p. 173.
} 


\section{CAPÍTULO 2}

\section{ESTADO DE EXCEÇÃO}

Segundo BRUNO Gulli, “... it is perhaps Agamben's greatest merit that he has provided a clear philosophical focus, as well as a forum, for an understanding of the political and ontological structure of the suspension of the law" ${ }^{206}$. Esta é a era da suspensão da lei, a era em que a criação voluntária de um estado de emergência permanente, ainda que, eventualmente, não declarado no sentido técnico, tornou-se uma das práticas essenciais dos Estados - ou melhor, governos - hodiernos, inclusive dos chamados democráticos ${ }^{207}$.

A lei é suspensa em toda sua facticidade como condição de sua própria existência, numa demonstração não somente motivada por interesses econômicos ${ }^{208}$, mas revelante da face mais obscura da soberania global e do ataque contra a lei. Cria-se uma anomia entre direito público e fato político, uma indistinção entre ordem jurídica e vida, de modo que " $a$ modernidade é a exceção em permanência" ${ }^{209}$. Para Agamben, essa terra di nessuno, ou estado de exceção, que “... independe de sua formalização constitucional ou legislativa"210, é, não mais, não menos, que o paradigma da governança dominante da política atual. Trata-se de uma verdadeira estratégia de eliminação daqueles que não fazem parte do corpo político integral, quer dizer, daqueles que estão sob o paradigma de uma vida nua ${ }^{211}$, inclusive de todas as populações do Terceiro Mundo em relação a seus dominantes ${ }^{212}$. Agamben coloca em suas próprias palavras a essência e os limites da vida.

\footnotetext{
${ }^{206}$ GULLI, Bruno. The ontology and politics of exception: reflections on the work of Giorgio Agamben. In: CALARCO, Matthew; DECAROLI, Steven (ed.). Giorgio Agamben: sovereignty and life. Stanford, California: Stanford University Press, 2007, p. 219.

${ }^{207}$ Cf. Giorgio AGAMBEN. Estado de exceção. São Paulo: Boitempo, 2004, p. 13.

${ }^{208}$ De acordo com Gilberto BERCOVICI, ao tratar da exceção econômica permanente, "A periferia vive em um estado de exceção econômico permanente, contrapondo-se à normalidade do centro. Nos Estados periféricos há o convívio do decisionismo de emergência para salvar os mercados com o funcionamento dos poderes constitucionais, bem como a subordinação do Estado ao mercado, com a adaptação do direito interno às necessidades do capital financeiro, exigindo cada vez mais flexibilidade para reduzir as possibilidades de interferência da soberania popular." In: Constituição e estado de exceção permanente: atualidade de Weimar. Rio de Janeiro: Azougue Editorial, 2004, p. 172.

${ }^{209}$ MATOS, Olgária. Modernidade: república em estado de exceção. In: Revista da Universidade de São Paulo. Setembro/outubro/novembro 2003. São Paulo: USP, CCS, 1989, p. 46.

${ }^{210}$ AGAMBEN, Giorgio. Estado de exceção. Tradução de Iraci D. Poleti. São Paulo: Boitempo, 2004, p. 23.

${ }^{211}$ Cf. HONESKO, Vitor Hugo Nicastro; HONESKO, Raquel Schlommer; BARBOSA, Tatiane Alves. In: O estado de exceção como causa da corrupção no sistema político-constitucional brasileiro. In: Revista do
} 
Nesse sentido, cumpre ressaltar ab initio que, para Agamben, a suspensão da lei real ou fictícia - não é nova na história e na política, assim como a vida nua não é uma emergência da modernidade, como analisado acima. O que é novidade é o fato de a suspensão tornar-se medida de dominação e controle globais, bem como o caminho mais certo para preservar a vida do dia a dia - a vida ordinária e corriqueira de todos nós - como vida nua. Ou seja, o que é realmente moderno para Agamben é a suspensão da lei não em decorrência de um estado de emergência a requerer medidas excepcionais ${ }^{213}$, mas o fato de que esse estado de emergência, calcado na sagaz administração do medo social - talvez até mesmo por meio de um coordenado inconsciente coletivo -, poderia possivelmente ${ }^{214}$ surgir: "... The actual suspension of the law enters now, and acts within, the realm of the potential; it is within potentiality (and of potentiality) that repression and control become most efficient and powerful".

Nessa potencialidade e "diante do incessante avanço do que foi definido como uma 'guerra civil mundial', o estado de exceção tende cada vez mais a se apresentar como o paradigma de governo dominante na política contemporânea"215. Quer dizer, a exceção agambeniana é balizada numa potencialidade, até mesmo porque advém do logos humano $^{216}$, de modo que a efetiva suspensão da lei age diuturnamente no âmago da potência, assim como a própria problemática do poder constituinte. Por conseguinte, para compreendermos a concepção do estado de exceção em Agamben, é imperativa uma sucinta análise da estrutura de ato e potência no seu pensamento.

Instituto dos Advogados de São Paulo, ano 9, n. 17, janeiro-julho 2006. São Paulo: Editora Afiliada, 2006, p. 267.

${ }^{212}$ Cf. Giorgio AGAMBEN. Means without end: notes on politics. Traducão Vincenzo Binetti e Cesare Casarino. Minneapólis: University of Minnesota Press, 2000, p. 35.

${ }^{213}$ Tema que será abordado em capítulo próprio.

${ }^{214}$ Um claro exemplo seria a passagem da justificação da guerra baseada na prova de posse efetiva de armas de destruição em massa pelo Iraque, para a justificação da guerra meramente baseada na potencialidade de o Iraque desenvolver tais armas.

${ }_{215}$ AGAMBEN, Giorgio. Estado de exceção. São Paulo: Boitempo, 2004, p. 13.

${ }^{216}$ Para Giorgio AGAMBEN, “... what specifically characterizes human logos, however, is that it is not always already in act, but exists, first and foremost, only in potentiality". In: The work of man. In: CALARCO, Matthew; DECAROLI, Steven (ed.). Giorgio Agamben: sovereignty and life. Stanford, California: Stanford University Press, 2007, p. 7. 


\subsection{A ONTOLOGia DA POTÊNCIA}

O que é potencialidade? Num breve texto denominado On Potentiality, originado de uma palestra conferida em Lisboa em 1986 e parte da obra Potentialities, que reúne uma série de textos do autor, Agamben explica que Aristóteles distingue - ao opor potencialidade e atualidade (dynamis e energeia) - duas formas de potencialidade. Uma é genérica, por exemplo, a potencialidade de uma criança aprender ou se tornar chefe de Estado; a outra é "existing potentiality" 217 , por exemplo, a potencialidade de um poeta escrever um poema ou, como exemplifica Aristóteles, “... a arte de construir",

A diferença repousa no fato de que, no primeiro caso, uma alteração precisa ser sofrida para que a potencialidade se torne atual, enquanto, no segundo caso, a potencialidade já está lá. É essa segunda forma de potencialidade - que, segundo DANIEL HELlER-ROAZEN, está presente e, ainda assim, “... do not appear in the form of present things" 219 - que interessa ambos Aristóteles e Agamben ${ }^{220}$, precisamente porque qualquer um que tenha potencialidade existente tem também a possibilidade de não a trazer ao ato, muito embora ela já exista na atualidade: "It is a potentiality that is not simply the potential to do this or that thing but potential to not-do, potential not to pass into actuality" ${ }^{221}$. Quer dizer, Agamben trata da completa autonomia da potencialidade em relação ao ato - a superação da primazia do ato -, de maneira que a potencialidade não tem a tarefa de passar ao ato, assim como o ser humano, em pura potencialidade, não tem, como veremos abaixo, nenhuma tarefa messiânica ou trabalho divino a completar, bem como qualquer destino a cumprir: não se trata, desde já, de cruzar os braços, mas de uma experiência ética agambeniana, livre de quaisquer tarefas ou obrigações. De acordo com Aristóteles:

\footnotetext{
217 AGAMBEN, Giorgio. On potentiality. In: HAMACHER, Werner; WELBERY, David (ed.). Potentialities. Tradução de Daniel Heller-Roazen. Stanford: Stanford University Press, 1999, p. 179.

${ }^{218}$ ARISTÓTELES. Metafísica. v. II, 2 ed. Tradução de Giovanni Reale. São Paulo: Edições Loyola, 2005, p. 397.

${ }^{219}$ HELLER-ROAZEN, Daniel. Editor' introduction: To read what was never written. In: HAMACHER, Werner; WELBERY, David (ed.). Potentialities. Tradução de Daniel Heller-Roazen. Stanford: Stanford University Press, 1999, p. 14.

${ }^{220}$ Cf. Bruno GULLI. Op. cit., p. 222. O próprio Agamben dirá que o primeiro caso acima exemplificado não interessa Aristóteles. In: On Potentiality. In: HAMACHER, Werner; WELBERY, David (ed.). Potentialities. Tradução de Daniel Heller-Roazen. Stanford: Stanford University Press, 1999, p. 179.

221 AGAMBEN, Giorgio. On Potentiality. In: HAMACHER, Werner; WELBERY, David (ed.). Potentialities. Tradução de Daniel Heller-Roazen. Stanford: Stanford University Press, 1999, p. 180
} 
"Impotência ou impotente é privação contrária a essa potência. Portanto, para a mesma coisa e segundo a mesma relação toda potência se contrapõe a uma impotência."222

Com efeito, para Agamben, uma adequada compreensão da potencialidade não pode deixar de lado a conceituação de impotencialidade - a potencialidade de não (adynamia) -, o que, à primeira vista, poderia parecer a contraparte negativa da potencialidade, mas que, em sua doutrina, é algo completamente distinto. A potencialidade de não em Agamben não é simplesmente a contraparte negativa da potencialidade porque ela não é a ausência de potencialidade, mas aquilo sem a qual a essência da própria potencialidade, na sua origem, não poderia ser pensada. Ela é a outra metade da história:

"Por isso, para que, digamos, a potência não se esvaneça a cada vez imediatamente no ato, mas tenha uma consistência própria, é preciso que ela possa até mesmo não passar ao ato, que seja constitutivamente potência de não (fazer ou ser)... Ela se mantém em relação com o ato na forma de suspensão, pode $\mathrm{o}$ ato podendo não realizá-lo, pode soberanamente a própria impotência." 223

É dizer, a potencialidade de não é ainda a própria potencialidade, e não um ser distinto; ela indica a possibilidade de um acuamento positivo do ato, como descrito no texto Bartleby, or on contingency. Com efeito, se a potencialidade fosse sempre a potência de ser ou fazer, tudo que é potencial já teria sido necessariamente convertido em ato, já que não haveria a faculdade de não ser ou não fazer, ou seja, todo potencial já teria sido trazido à atualidade, e a potencialidade a fortiori nunca existiria como tal: “... quem está de pé deverá ficar sempre de pé e quem está sentado deverá ficar sempre sentado"224. O exemplo dado por Agamben é a existência, ou experiência, da visão em relação à escuridão: se a visão não fosse uma potencialidade na atualidade da luz, nós nunca poderíamos experimentar a escuridão. Nós temos a potencialidade de não ver, e, portanto, a possibilidade da privação da potencialidade da visão:

\footnotetext{
${ }^{222}$ ARISTÓTELES. Metafísica. v. II, 2 ed. Tradução de Giovanni Reale. São Paulo: Edições Loyola, 2005, p. 397.

${ }^{223}$ AGAMBEN, Giorgio. Homo sacer: o poder soberano e a vida nua I. Tradução de Henrique Burigo. Belo Horizonte: Editora UFMG, 2002, p. 52.

${ }^{224}$ ARISTÓTELES. Metafísica. Op. cit., p. 403.
} 
"Other living beings are capable only of their specific potentiality; they can only do this or that. But human beings are the animals who are capable of their own impotentiality. The greatness of human potentiality is measured by the abyss of human impotentiality.,"225

Ponderando sobre o livro Nono da Metafísica de Aristóteles ${ }^{226}$, Agamben sustenta que a essência da potencialidade, assim como a essência da própria autonomia da potencialidade, é a relação que ela tem com sua própria privação, seu próprio não-ser. Ser potencial significa ser sua própria privação, ou seja, “... para que, digamos, a potência não esvaneça a cada vez imediatamente no ato, mas tenha uma consistência própria, é preciso que ela possa até mesmo não passar ao ato, que seja constitutivamente potência de não (fazer ou ser), ou, como Aristóteles diz, que ela seja também impotência (adynamía),227.

Esclarecida a natureza da potencialidade enquanto igualmente potenza di non (fare o essere), como se dá, então, a sua passagem ${ }^{228}$ à realidade em Agamben? A resposta está igualmente na interpretação da Metafísica de Aristóteles, para quem, "esti de dynaton touto, hoi ean hyparxei hé energeia ou legetai ekhein tén dynamén, ouden estai adynaton,"229.

225 AGAMBEN, Giorgio. On potentiality. In: HAMACHER, Werner; WELBERY, David (ed.). Potentialities. Tradução de Daniel Heller-Roazen. Stanford: Stanford University Press, 1999, p.182.

${ }^{226}$ Contrapondo-se aos Megarianos, para os quais a potencialidade só existiria no ato (é dizer, não haveria autonomia da potencialidade), Aristóteles dirá que "Alguns pensadores como, por exemplo, os megáricos, sustentam que só existe potência quando existe ato, e que quando não existe o ato também não existe potência... os absurdos que derivam dessas afirmações são facilmente compreensíveis". ARISTÓTELES. Metafísica. v. II, 2 ed. Tradução de Giovanni Reale. São Paulo: Edições Loyola, 2005, p. 401.

${ }^{227}$ AGAMBEN, Giorgio. Homo sacer: o poder soberano e a vida nua I. Tradução de Henrique Burigo. Belo Horizonte: Editora UFMG, 2002, p. 52.

228 Segundo Eduardo C. B. BITTAR, essa passagem (movimento) em Aristóteles não é meramente quantitativa (deslocamento), mas qualitativa (alteração), como aumento ou diminuição. In: Curso de filosofia aristotélica: leitura e interpretação do pensamento aristotélico. Barueri: Manole, 2003, p. 551.

${ }^{229}$ Traduzido ao português como “... algo é em potência se o traduzir-se em ato daquilo de que se diz ser ele em potência não implica nenhuma impossibilidade”. In: ARISTÓTELES. Metafísica. Op. cit., p. 403; ou “.. uma coisa é capaz de produzir determinado efeito quando a sua passagem da potência ao ato não envolve nenhuma impossibilidade". In: ARISTÓTELES. Metafísica. Tradução de Leonel Vallandro. Porto Alegre: Editora Globo, 1969, p. 194; ao espanhol como "Digo que una cosa es posible cuando su tránsito de la potencia al acto no entraña ninguna imposibilidad”. In: ARISTÓTELES. Metafísica. 3. ed. Tradução de Patricio de Azcárte. Buenos Aires: Ed. Espana-Calpe Argentina S.A., 1945, p. 189; ao inglês como " $A$ thing is said to be potential if, when the act of which it is said to be potential is realized, there will be nothing impotential". In: AGAMBEN, Giorgio. On potentiality. In: HAMACHER, Werner; WELBERY, David (ed.). Potentialities. Tradução de Daniel Heller-Roazen. Stanford: Stanford University Press, 1999, p.183. 
A leitura do "... não implica nenhuma impossibilidade", ou "... não envolve nenhuma impossibilidade", ou "... no entraña ninguma imposibilidad", ou "there will be nothing impotential", de Agamben é desafiadora. Se é verdade que a impotencialidade referida por Aristóteles é a impotencialidade qualificada acima - ou potencialidade de não, que pertence à própria potencialidade -, então essa impotencialidade deve passar igualmente ao ato, assim como o faz a potencialidade. Destarte, o there will be nothng impotential em Agamben não deve ser entendido como uma impotencialidade que ficou para trás porque se realizou a potencialidade positiva, mas como uma impotencialidade que igualmente teve sua completa realização na travessia ao ato. É nesse sentido que restará nenhuma impotencialidade.

Ou seja, a potenza agambeniana, em que pese sua autonomia e relação ao atto, sempre mantém uma relação com a impotencialidade na passagem à atualidade, de maneira que a própria atualidade apareça não simplesmente como um sendo ou fazendo, mas como um não não-sendo e um não não-fazendo. Nesse sentido, “... o potente pode passar ao ato somente no ponto em que depõe a sua potência de não ser (a sua adynamía)",230 (Il potente può passare all'atto solo nel punto in cui depone la sua potenza di non essere), e a atualidade aparece como uma negação da impotencialidade ou, em outras palavras, a negação da negação ${ }^{231}$.

É dessa conceituação que, no capítulo Apostila adicionado ao livro Stanze: la parola e il fantasma nella cultura occidentale em 1993 (a obra é de 1977), Agamben exemplifica a relação entre ato e potência no processo de criação de uma obra:

"O ato de criação não é, na realidade, segundo a instigante concepção corrente, um processo que caminha da potência para o ato para nele se esgotar, mas contém no seu centro um ato de descriação, no qual o que foi e o que não foi acabam restituídos à sua unidade originária na mente de Deus, e o que podia não ser e foi se dissipa no que podia ser e não foi." ${ }^{232}$

\footnotetext{
${ }^{230}$ AGAMBEN, Giorgio. Homo sacer: o poder soberano e a vida nua I. Tradução de Henrique Burigo. Belo Horizonte: Editora UFMG, 2002, p. 53.

${ }^{231}$ Cf. Catherine MILLS. The philosophy of Agamben. McGill-Queen's University Press, 2008, p. 3.

${ }^{232}$ AGAMBEN, Giorgio. Estâncias: a palavra e o fantasma na cultura ocidental. Tradução de Selvino José Assmann. Belo Horizonte: Editora UFMG, 2007, p. 252.
} 
Forçoso concluirmos que, para Agamben, a potencialidade não desaparece ou é anulada na passagem à realidade, bem como na própria realidade. Pelo contrario, ela se preserva como tal e, confundindo-se com o ato, torna-se dele indistinta ${ }^{233}$. Em que pese a clareza do raciocínio agambeniano neste ponto específico, GULLI entende que a interpretação agambeniana merece ser desenvolvida:

"I do not disagree with this interpretation, but I think it need to be qualified and developed. What Agamben is here pointing to is the modality of the could, but he does not name it, for he begins this essay by asking: 'What do I mean when I say: 'I can, I cannot'?', and he remains within the framing of this question, within the can modality. Yet, as both Duns Scotus and Deleuze show, it is from the perspective of the could, the open series of disjunctions (or...or...or...or...), the plurality of possibilities, that true potentiality become evident. The could allows for a could have, a perfective, which is logically and ontologically forbidden to the can. This coud have, which neutralizes itself in determination, is what show forth in Agamben`s interesting interpretation of Aristotle's definition: this could have is the impotentiality that 'does not lag behind actuality but passes fully into it as such'... The essential relation between potentiality and the potentiality not to is not a relation between two elements of an absolute constitution - it is not an either/or - but rather, it is the open indeterminacy that precedes the act, that can even neutralize the act."234

Em outras palavras, a potencialidade é entendida como uma indeterminação entre possibilidade e atualidade. A potencialidade agambeniana parece flutuar entre essas duas determinações. E continua o crítico de Agamben:

"To cause what one is also able not to cause is certainly a definition, not only of contingency, but also what Agamben calls the 'essence of potentiality', that is, the relation between potentiality and potentiality not to. Once the causing is accomplished and potentiality passes over into actuality, the 'I can and I

\footnotetext{
233 "Since, in addition, the passage from potentiality to actuality can be said to involve not the destruction of potentiality (as impotentiality) but rather its conservation, the distinction between potentiality and actuality disappears... Rather than potentiality and actuality being distinct modes of being, then, they enter a zone of indistinction". AGAMBEN, Giorgio. Whatever Politics. In: CALARCO, Matthew; DECAROLI, Steven (ed.). Giorgio Agamben: sovereignty and life. Stanford, California: Stanford University Press, 2007, p. 76.

${ }^{234}$ GULLI, Bruno. Op. cit., p. 223.
} 
cannot' of now becomes an 'I did and I could have not'; it is in this latter form that impotentiality also passes fully into actuality and is preserved as such... All that this says is that we act in the midst of absolute indeterminacy, in the neutrality or neither/nor of the potential ..."235

A estrutura ontológica do "neither/nor"236, ou não/nem, ou non/né - como visto, uma absoluta indeterminação -, nomeia, portanto, o conceito de potencialidade em Agamben. Dissemos estrutura ontológica porque, como visto acima, a potencialidade não é dividida do atual no sentido de estar fora da realidade. Pelo contrario, a existência autônoma da potencialidade torna-a absolutamente existente na atualidade. A atualidade, nesse raciocínio, não pode ser reduzida ao dado empírico, mas deve considerar a potencialidade que precisamente fundamenta o que é dado, ainda que não em termos mecânicos. O atual, ontologicamente falando, não precisa de mecanicidade para se tornar real.

Não por outra razão o pensamento de Agamben é tido entre aqueles que constantemente relacionam ontologia e política. Um vínculo que não é resultado da mera justaposição de duas esferas diferentes de pensamento, mas uma de conexão íntima. Com efeito, em suas obras, Agamben enfatiza duas figuras fundamentais e conectadas: a estrutura do não/nem e o conceito de exceção - a bem da verdade, é na estrutura do não/nem que a exceção encontra seu fundamento.

Como veremos abaixo, a estrutura da potencialidade corresponde àquela da operação da soberania em Agamben, pois, para o filósofo italiano, a força particular do soberano em relação à exceção é que ele se mantém indefinidamente em sua própria potencialidade, ou seja, à sua própria não-passagem à atualidade. Isso significa que o problema da soberania retorna a filosofia jurídico-política à ontologia ${ }^{237}$, porquanto "The passage from potentiality to sovereignty is accomplished through the structure of

\footnotetext{
${ }^{235}$ GULLI, Bruno. Op. cit., p. 224.

${ }^{236}$ Cf. GULLI, Bruno. Op. cit., p. 220.

237 "To understand sovereignty and the sovereign ban, then, it is necessary to think potentiality without any relation to actuality. The long-standing distinction between potentiality and actuality must be abandoned, and instead a potentiality must be conceived as a form of actuality and vice versa". EDKINS, Jenny. Whatever Politics. In: CALARCO, Matthew; DECAROLI, Steven (ed.). Giorgio Agamben: sovereignty and life. Stanford, California: Stanford University Press, 2007, p. 77.
} 
exception ${ }^{233}$. É essa conceituação de potencialidade que possibilitará a compreensão da dupla figura da exceção: o potere sovrano e la nuda vita ${ }^{239}$.

\subsection{O DEBATE ENTRE GIGANTES}

A suspensão da lei para a preservação da ordem é um tema que se encontra no cerne de todo sistema político-jurídico. Quando colocada em crise, seja por dissenso público, crise, anarquia, violência, tumulto, instabilidade econômica ou mesmo por aqueles que possuam muita influência, o poder soberano responde - usualmente por meio de um direito de exceção - com a suspensão da lei, uma vez que o que está em jogo é a própria conexão que une a soberania com o território sobre o qual ela exerce o seu poder, bem como sobre a obediência ${ }^{240}$ da qual ela própria depende.

Quando essa vertente da vida é rompida, a soberania corre o risco de perder seu poder justamente porque o vínculo entre autoridade e território - o simples nascimento, enquanto imediata nação ${ }^{241}$, ao menos a partir do homem como citoyen - corre o risco de desfazer-se. Sempre que esse vínculo é colocado em dúvida, a soberania rebate rapidamente. Mas, afinal, o que está acontecendo com a soberania? A soberania está ora submetida ao capital mundial, aos direitos humanos internacionais ou mesmo à crise ecológica global, ou ela permanece irretorquível, ainda que seus fundamentos estejam alterados?

\footnotetext{
${ }^{238}$ GULLI, Bruno. Op. cit., p. 225.

239 Segundo JENNY EDKINS, o banimento soberano e a estrutura da potencialidade são intimamente relacionadas uma vez que, assim como o banimento soberano se aplica à exceção ao não mais se aplicar, a potencialidade mantém-se em relação com a atualidade por meio de sua habilidade de não ser. Op. cit., p. 76. ${ }^{240}$ A "obrigação legal da obediência" é, para Foucault, inerente à teoria do direito a partir da Idade Média, em que “... O sistema do direito é inteiramente centrado no rei”. In: Vigiar e Punir: nascimento da prisão. Tradução de Raquel Ramalhete. 36 ed. Rio de Janeiro: Vozes, 2009, p. 181.

${ }^{241}$ Para Agamben, a ficção criada na Declaração de 1789 “... é a de que o nascimento torne-se imediatamente nação, de modo que entre os dois termos não possa haver resíduo algum". Isso porque "A nação, que etimologicamente deriva de nascere, fecha assim o círculo aberto pelo nascimento do homem". Em outras palavras, para Agamben o Estado-nação moderno é um Estado em que a natividade é a fundação de sua própria soberania, principalmente à luz da Declaração de 1789. In: Homo sacer: o poder soberano e a vida nua I. Tradução de Henrique Burigo. Belo Horizonte: Editora UFMG, 2002, p. 135. Cf. Giorgio AGAMBEN. In: Means without end: notes on politics. Traducão Vincenzo Binetti e Cesare Casarino. Minneapólis: University of Minnesota Press, 2000, p. 21.
} 
É no debate entre Carl Schmitt e Walter Benjamin que Agamben encontrará subsídios para a resolução - se é que ela realmente existe - ao paradoxo ${ }^{242}$ da soberania, que teria se afirmado ainda mais na recente modernidade à luz de uma inserção mais aprofundada do Estado na vida biológica ${ }^{243}$. Assim, imprescindível traçarmos as idéias mestras desse tema nas doutrinas de Benjamin e Schmitt ${ }^{244}$, o que faremos por meio da interpretação das obras desses autores à luz dos capítulos Gigantomachia intorno a un vuoto e Forza-di-legge de Stato di eccezione, bem como das observações de Jacques Derrida na segunda parte de Force de loi: le fondement mystique de l'autorité.

Nesses capítulos, Agamben defenderá que a caracterização do estado de exceção defendida por Schmitt é de fato nada mais que uma resposta à busca benjaminiana de uma inteira esfera anômica de atuação humana capturada na noção de uma violência sem relação com o direito ou com a soberania, porquanto “... o nexo irredutivel que une violência e direito faz da Crítica benjaminiana a premissa necessária, e ainda hoje insuperada, de todo estudo sobre a soberania, ${ }^{245}$. Agamben inverte a ordem tradicional do diálogo Benjamin-Schmitt, colocando em xeque todos aqueles que veem nos textos de Benjamin um inexplicável ou escandaloso interesse na teoria schmittiana ${ }^{246}$.

\footnotetext{
${ }^{242}$ William RASCH, ao comentar o paradoxo na visão de Agamben, Schmitt e Benjamin, esclarece que, conquanto existam divergências, “.... they all agree: that the paradox of sovereignty, no matter how resolved, is the common structure of all modern political life - indeed, perhaps all political life since Aristotle". In: From sovereign ban to banning sovereignty. In: CALARCO, Matthew; DECAROLI, Steven (ed.). Giorgio Agamben: sovereignty and life. Stanford, California: Stanford University Press, 2007, p. 99.

${ }^{243}$ Como analisado acima, Agamben parece concordar com Foucault quanto à proeminência de questões de biologia em decisões estatais modernas: aborto, inseminação artificial, a linha entre vida e morte, transplantes de órgãos, é dizer, a biopolítica.

${ }^{244}$ E não poderia ser de outra forma, visto que para Agamben “... a tentativa mais rigorosa de construir uma teoria do estado de exceção é obra de Carl Schmitt, principalmente em Die Diktatur [1921] e em Politische Theologie, publicado um ano mais tarde". In: Estado de exceção. Tradução de Iraci D. Poleti. São Paulo: Boitempo, 2004, p. 53.

${ }^{245}$ AGAMBEN, Giorgio. Homo sacer: o poder soberano e a vida nua I. Tradução de Henrique Burigo. Belo Horizonte: Editora UFMG, 2002, p. 72.

${ }^{246}$ Agamben faz uma série de comentários acerca do dossiê esotérico entre Benjamin e Schmitt sobre o estado de exceção. Agamben inverterá os termos do escândalo, lendo a teoria schmittiana da soberania como uma resposta à crítica benjaminiana da violência e não o contrário. Isto é, a doutrina da soberania de Schmitt deve ser lida como uma resposta ao ensaio benjaminiano. Agamben parte dessa premissa para expressar que o primeiro documento do debate não deve ser a leitura benjaminiana de Teologia Política, mas sim a leitura schmittiana do ensaio benjaminiano Crítica da violência, publicado no v. 47 da Archiv fur Sozialwissenschaften und Sozialpolitik. Por oportuno, Agamben reconhece que Benjamin não nomeia o estado de exceção de início, embora use o termo Ernsfall, que, em Schmitt, aparece como sinônimo de Ausnahmezustand. Assim, para Agamben, a posterior “... descrição benjaminiana do soberano barroco no Trauerspielbuch pode ser lida como uma resposta à teoria schmittiana da soberania" In: AGAMBEN, Giorgio. Estado de exceção. Tradução de Iraci D. Poleti. São Paulo: Boitempo, 2004, p. 84-87.
} 
Essa esfera anômica nos remete justamente ao ensaio benjaminiano Zür kritik der gewalt und andere aufsätze, de 1921, e igualmente Ursprung der deutschen trauerspiels, de 1925, nos quais o autor pensa numa força, ou melhor, numa violência (Gewalt ${ }^{247}$ ), que fosse tanto distinta da violência que funda o direito quanto da violência que conserva o direito $^{248}$. É a chamada violência divina ou pura $^{249}$. IRVING WOHLFARTH, no texto On some jewish motifs in Benjamin, explica a origem teológica ${ }^{250}$ do direito para Benjamin em sua leitura do Gênesis, de maneira que possamos analisar a proposta de um retorno - mas sem voltar ao passado - à violência divina:

"In the beginning was the word. The Fall, according to Benjamin, is first and foremost the fall of language. It is a fall from the god-inspired language of names and, concomitantly, from the birth of the human word. As it falls from its original state of being into having, language becomes synonymous with 'abstraction', 'judgment' and 'meaning'. It ceases to be a 'medium', and degenerates into a 'means' of intersubjective 'communication'. 'The word', writes Benjamin, 'must communicate something (outside itself)'. The Fall is thus the origin of reification, the birth of the 'thing' (Sache) qua 'something', and, by the same token, the Genesis of the subject and the law."251

Desse modo, "upon eating the tree of knowledge, man abandons the magic circle, the plenitude, of pure speech. The crime calls forth its punishment: to exile oneself from pure language is already to be expelled from Paradise" ${ }^{252}$. A linguagem, que era um puro

247 O significado da palavra Gewalt é ambíguo e pode ser igualmente entendido como força legítima, violência autorizante ou autorizada, ou mesmo domínio ou soberania do poder legal, conforme leciona Jacques Derrida. Op. cit., p. 9-10, 68 e 73. Gewalt também pode ser entendida por potência, em contraste à força (Macht), como leciona Bobbio. Cf. Norberto BOBBIO. Direito e poder. Tradução de Nilson Moulin. São Paulo: UNESP, 2008, p. 173.

${ }^{248}$ Jacques Derrida qualifica essas violências da seguinte forma: "Há, primeiramente, a distinção entre duas violências do direito, duas violências relativas ao direito: a violência fundadora, aquela que institui e instaura o direito (die rechtsetzende Gewalt) e a violência conservadora, aquela que mantém, confirma, assegura a permanência e a aplicabilidade do direito (die rechtserhaltende Gewalt). In: DERRIDA, Jacques. Força de lei: o fundamento místico da autoridade. Tradução de Leyla Perrone-Moisés. São Paulo: Martins Fontes, 2007, p. 73.

${ }^{249}$ Pura porque essa violência deve ser entendida nela mesma, independentemente de quaisquer fins, justos ou não, morais ou não. Cf. Jacques DERRIDA. Op. cit., p. 75.

${ }^{250}$ Benjamin é antes de tudo um teólogo judeu, um pensador messiânico que tenta conciliar marxismo e teologia judaica, materialismo e messianismo. De acordo com Michael Löwy, Benjamin é um marxista e um teólogo. Cf. Michael LÖWY. In: Walter Benjamin: aviso de incêndio: uma leitura das teses "Sobre o conceito de história". Tradução de Wanda Nogueira Caldeira Brant. São Paulo: Boitempo, 2005, p. 36.

251 WOHLFARTH, Irving. On some jewish motifs in Benjamin. In: BENJAMIN, Andrew (ed.). The problems of modernity: Adorno and Benjamin. London and New York: Routledge, 1998, p. 157.

${ }^{252}$ WOHLFARTH, Irving. Op. cit., p. 157. 
meio e comunicava nada mais do que a si mesma, passou a comunicar algo, passou a ser o meio destinado a um fim, passou a ter uma tarefa. A queda da linguagem é, ato contínuo, identificada como a maldição do homem como técnica de trabalho: diante da expulsão do Paraíso, a natureza passa a ser um objeto de manipulação técnica - trabalho - e não mais um objeto de contemplação, ou seja, uma linguagem silenciosa a ser ouvida. Com a queda de todas as fundações, o homem se emancipa ${ }^{253}$ e cai na subjetividade: a imanência mágica é abandonada ${ }^{254}$.

Ocorre então, segundo Michael LöWY, a “... transformação dos seres humanos em 'máquinas de trabalho', a degradação do trabalho a uma simples técnica, a submissão desesperadora das pessoas ao mecanismo social ${ }^{\text {255 }}$. De acordo com esse autor, a teologia para Benjamin remete a dois conceitos fundamentas: a rememoração (Eingedenken) e a redenção messiânica (Erlösung), no sentindo de que a teologia não é um objetivo em si, não visa à contemplação inefável de verdades eternas e à reflexão sobre a natureza do Ser divino, mas como algo a serviço da luta dos oprimidos ${ }^{256}$. Mais precisamente, ela está a serviço do reestabelecimento de uma força messiânica, revolucionária do materialismo histórico ${ }^{257}$.

Essa redenção messiânica/revolucionária pressupõe a reparação do abandono e da desolação do passado, uma rememoração histórica das vítimas do passado e, por derradeiro, a realização dos objetivos inatingidos: "Não há um Messias enviado do céu: somos nós o Messias, cada geração possui uma parcela do poder messiânico e deve se esforçar para exercê-la"258. Não se trata de esperar o Messias, mas de um agir coletivo, ativo e redentor do presente, porquanto a história lhe parece como uma sucessão de vitórias dos poderosos. $\mathrm{O}$ messias, nesse sentido, é a própria humanidade à procura da volta de

\footnotetext{
253 "The Fall of man is thus the synonimous with the genesis of the subject. It is also the origin of all improper knowledge (Wissen), all alienation, all epistemological dualisms... Thus, the Fall is already, in some sense, the infernal machine of modernity, the free fall of history". WOHLFARTH, Irving. Op. cit., p. 161.

${ }^{254}$ Cf. Irving WOHLFARTH. Op. cit., p. 159-161.

${ }^{255}$ LÖWY, Michael. Op. cit., p. 20.

${ }^{256}$ Para Löwy, a associação entre teologia e marxismo teria servido de inspiração - em que pesem as diferenças em diversos aspectos - a fenômenos históricos como A Teologia da Libertação na América Latina que, por sua vez, teria influenciado a formação do novo movimento operário e camponês brasileiro, leia-se Partido dos Trabalhadores e Movimento dos Sem Terra. LÖWY, Michael. Op. cit., p. 46.

${ }^{257}$ Cf. Michael LÖWY. Op. cit., p. 44-45.

${ }^{258}$ LÖWY, Michael. Op. cit., p. 51.
} 
todas as coisas ao seu estado originário, mas, ainda assim, como algo novo - no Evangelho, o restabelecimento do Paraíso pelo Messias ${ }^{259}$.

Benjamin, por meio de uma dialética do material e do espiritual, seculariza a dimensão teológica do conceito de reino de Deus na forma de uma sociedade fundada sob a fé, a coragem, a perseverança, o humor e a astúcia dos oprimidos. Ao analisar a sexta das Teses sobre a filosofia da história, MichAEL LÖWY concluirá que o Messias tem seu equivalente profano nos núcleos de resistência antifacista, enquanto o Anticristo poderia ser representado, sem dúvida alguma no seu entender, pelo Terceiro Reich hitlerista ${ }^{260}$. É assim que, para JACQUES DERRIDA, Zür kritik der gewalt inscreve-se “... numa perspectiva judaica que opõe a justa violência divina (judia), que destrói o direito, à violência mítica (da tradição grega), que instaura e conserva o direito",261. De acordo com Agamben, o objetivo do ensaio benjaminiano é o seguinte, citando Benjamin:

“... garantir a possibilidade de uma violência (o termo alemão Gewalt significa também simplesmente 'poder') absoltamente 'fora' (ausserhalb) e 'além' (jenseits) do direito e que, como tal, poderia quebrar a dialética entre violência que funda o direito e violência que o conserva (rechtsetzende und rechtserhaltende Gewalt). Benjamin chama essa outra figura da violência de 'pura' (reine Gewalt) ou de 'divina' e, na esfera humana, de 'revolucionária'. $\mathrm{O}$ que o direito não pode tolerar de modo algum, o que sente como uma ameaça contra a qual é impossível transigir, é a existência de uma violência fora do direito; não porque os fins de tal violência sejam incompatíveis com o direito, mas 'pelo simples fato de sua existência fora do direito' (Benjamin, 1921, p. 183)."262

Explica-se: partindo da distinção entre duas violências, a violência fundadora e a violência conservadora (ou, em conjunto, violência mítica ${ }^{263}$ ), mas considerando que

\footnotetext{
${ }^{259}$ Cf. Michael Löwy. Op. cit., p. 551.

${ }^{260}$ Cf. Michael Löwy. Op. cit., p. 68.

${ }^{261}$ DERRIDA, Jacques. Op. cit., p. 62.

${ }^{262}$ AGAMBEN, Giorgio. Estado de exceção. Tradução de Iraci D. Poleti. São Paulo: Boitempo, 2004, p. 81.

${ }^{263}$ William Rasch qualifica essas violências: "The violence that demands obedience to the existing law is rechtserhaltend (law-preserving), while the violence that founds the law, that establishes the necessary asymmetry by means of self-exemption, is rechtsetzend (law-positing). This latter violence opens up an ordered space that the former preserves. Benjamin names both types of legal violence 'mythic'... Benjamin, it
} 
aquela é por vezes representada nesta numa contaminação diferencial ${ }^{264}$ - não há rompimento, mas refundação para conservação ${ }^{265}$, é dizer, uma dialética circular -, Benjamin busca uma saída à crise do conceito de direito ${ }^{266}$, então aparentemente inseparável do modelo europeu de democracia burguesa e liberal, por meio de uma violência “destruidora" ${ }^{, 267}$ do direito (Rechtsvernichtend). A bem da verdade, como bem explica ARNE DE BOEVER, a verdadeira interpretação que se deve dar à função da violência divina, que tem seu equivalente profano na revolução dos oprimidos acima citada, não é destruir, mas:

"The verb that Benjamin chooses to describe the work of the divine violence is not 'destroy' ('vernichten', as one might expect) or even 'abolish' (as the English translation has it) but 'aufheben'. When he uses the word 'Vernichtung' it is in combination with the word 'Aufgabe', which, as commentators on Benjamin's translation essay have tirelessly pointed out, contains both the semantic components of a 'task' and a 'letting go'. One shouldn't conclude too quickly that 'destruction' is the 'task' that Benjamin sets before the reader, but rather, 'let go' of such easy readings (and politics)." 268

Michael Löwe, por sua vez, revela a idéia de uma Aufhebung em Benjamin como a de supressão da injustiça passada à luz de uma consciência histórica, muito embora o termo superação seja igualmente utilizado por ele ${ }^{269}$. Benjamin parece questionar o interesse que o direito tem de se instaurar e conservar a si mesmo e, consequentemente, o monopólio da violência enquanto Gewalt, ou seja, violência enquanto também autoridade,

can therefore be said, emphasizes the unity of the distinction between constituting and constituted violence by labeling them, collectively, 'mythic". RASCH, William. Op. cit., p.

${ }^{264}$ Essa expressão é cunhada por Derrida e não Benjamin. Cf. Jacques DERRIDA. Op. cit., p. 90.

${ }^{265}$ Essa ausência de rompimento é corroborada por Jacques Derrida. Op. cit. p. 89.

${ }^{266}$ A frase etwas Morsches im Recht bem qualifica a visão de Benjamin. Para Derrida, Benjamin entende que "há algo de carcomido ou de podre no direito, algo que o condena ou o arruína de antemão. O direito está condenado, arruinado, em ruína...”. Cf. Jacques DERRIDA. Op. cit., p. 90-91.

${ }^{267}$ Cf. Jacques DERRIDA. Op. cit., p. 74.

${ }^{268}$ BOEVER, Arne de. Politics and poetics of divine violence: on a figure in Giorgio Agamben and Walter Benjamin. In: CLEMENS, Justin; HERON, Nicholas; MURRAY, Alex (ed.). The work of Giorgio Agamben: law, literature, life. Edinburg University Press, 2008, p. 92.

${ }^{269}$ LÖWY, Michael. Op. cit., p. 50 e 63. 
por meio da polícia ${ }^{270}$ - uma figura sem rosto que age sob mera força de lei -, em detrimento de determinados valores justos.

Ou seja, a polícia suspende o momento de separação da violência fundadora e da violência conservadora e se comporta como um legislador nos tempos modernos, “... para não dizer o legislador dos tempos modernos"271. Onde há polícia, ou seja, em toda parte, há violência fantasmagórica e o permanente paradoxo da iterabilidade, pelo qual a origem, para valer como origem, deve repetir-se e se alterar para se conservar. Uma violência sem forma (gestaltlos). Para HANNAH ARENDT, essa forma de polícia surgiu quando da incapacidade de os Estados-nação resolverem a questão dos refugiados no século XX:

“O Estado-nação, incapaz de prover uma lei para aqueles que haviam perdido a proteção de um governo nacional, transferiu o problema para a polícia. Foi essa a primeira vez em que a polícia da Europa ocidental recebeu autorização para agir por conta própria, para governar diretamente as pessoas; nessa esfera da vida pública, já não era um instrumento para executar e fazer cumprir a lei, mas se havia tornado autoridade governante independente de governos e de ministérios." 272

Já para os pares de Benjamin na Escola de Frankfurt, THEODOR ADORNO e MAX HoRKHEIMER, essa polícia, como longa manus do governo de outrora, isto é, polícia enquanto próprio governante, numa indistinção entre soberano e governo, parece existir até mesmo por meio da propaganda e dos meios de comunicação: “O rádio torna-se aí a voz universal do Führer; nos alto-falantes de rua, sua voz se transforma no uivo de sirenes anunciando o pânico, das quais, aliás, a propaganda moderna é difícil de se distinguir... $O$ carisma metafísico do Führer, inventado pela sociologia da religião, acabou por se revelar como a simples onipresença de seus discursos radiofônicos, que são uma paródia demoníaca da onipresença do espírito divino... Um belo dia, a propaganda de marcas

\footnotetext{
${ }^{270}$ Para Derrida, “... a polícia que capitaliza a violência não é apenas a polícia. Ela não consiste somente em agentes policiais fardados, às vezes com capacetes, armados e organizados numa estrutura civil de modelo militar. mas uma figura sem rosto de um Dasein coextensivo ao Dasein da pólis". Para o autor, “... a polícia não se contenta, hoje, em aplicar a lei pela força (enforce) e, portanto, em conservá-la; ela a inventa, ela publica decretos, ela intervém cada vez que a situação jurídica não é suficientemente clara para garantir a segurança. Ela é a força de lei, ela tem força de lei”'. Op. cit., p. 99 e 102-103.

${ }^{271}$ Cf. Jacques DERRIDA. Op. cit., p. 99.

${ }^{272}$ ARENDT, Hannah. Origens do totalitarismo. Tradução de Roberto Raposo. São Paulo: Companhia das Letras, 1989, p. 321.
} 
específicas, isto é, o decreto da produção escondido na aparência da possibilidade de escolha, pode acabar se transformando no comando aberto do Führer... O Führer ordena de maneira mais moderna e sem maior cerimônia tanto o holocausto quanto a compra de bugigangas" 273 .

O discurso benjaminiano, destarte, ataca a polícia onipotente e a democracia representativa corrompida - assim como Agamben também o faz -, de maneira que uma verdadeira democracia ainda estaria por vir. De acordo com BENJAMIN, "Ao passo que o conceito moderno de soberania resulta no exercício pelo Príncipe de um poder executivo supremo, o do Barroco nasce de uma discussão sobre o estado de exceção, e considera que impedi-lo é a mais importante função do Príncipe" ${ }^{\text {274 }}$. Não por outra razão, na oitava das Teses sobre a filosofia da história Benjamin dirá, em sua célebre máxima, que " $A$ tradição dos oprimidos ensina-nos que o 'estado de exceção' no qual vivemos é a regra. É-nos preciso elaborar uma concepção da história que corresponda a um tal estado. A partir dai constataremos que a nossa tarefa consiste em criar um verdadeiro estado de exceção; e assim tornar-se-á melhor a nossa posição na luta contra o fascismo"275. Nessa frase, Benjamin revela que a barbárie e a violência dos vencedores é a norma, ao menos do ponto de vista dos oprimidos à luz da administração total - no sentido de fascismo - então imperante. Assim, o estado de exceção permanente e inspirado pela ideologia do progresso é a história da opressão de classe.

Sua sugestão à resolução da problemática é dupla, como sempre: religiosa e profana, teológica e política. A sociedade sem classes é o novo Paraíso e o progresso moderno (a tempestade bíblica) deve ser freado. É nesse sentido que surge essa terceira figura, que Benjamin nomeia violência divina. Uma violência que não põe nem conserva o direito, mas o expõe e o depõe (entsetzt), assertiva que parece ser corroborada por Agamben ao declarar a necessidade de uma figura que “... rompa a dialética circular entre

\footnotetext{
273 ADORNO, Theodor W.; HORKHEIMER, Max. Dialética do esclarecimento. Tradução de Guido Antonio de Almeida. Rio de Janeiro: Jorge Zahar Ed., 1985, p. 132.

${ }^{274}$ BENJAMIN, Walter. Origem do drama barroco alemão. Tradução de Sérgio Paulo Rouanet. São Paulo: Brasiliense, 1984, p. 89.

${ }^{275}$ BENJAMIN, Walter. Sobre arte, técnica, linguagem e política. Tradução de Maria Luz Moita e Manuel Alberto. Lisboa: Relógio D’água Editores, 1992, p. 161.
} 
essas duas formas de violência"276 . Citando uma vez mais Benjamin, Agamben exterioriza que:

"A lei destas oscilações (entre violência que põe e violência que conserva o direito) baseia-se no fato de que toda violência conservadora enfraquece, ao longo do tempo, indiretamente por meio da repressão das forças hostis, a violência criadora que é representada nela... Isto dura até o momento em que novas forças, ou aquelas primeiramente oprimidas, tomam a dianteira em relação à violência que até então havia posto o direito, e fundam assim um novo direito destinado a uma nova decadência. Sobre a interrupção deste ciclo, que se desenrola no âmbito das forças míticas do direito, sobre a deposição do direito juntamente com as forças que ele se apóia (assim como estas nele), e, portanto, em definitivo do Estado, se baseia uma nova época histórica."277

Essa nova figura questionaria igualmente a figura do soberano, como bem nota WILLIAM RASCH: “Walter Benjamin... recognized that if one wished to transcend sovereignty, one needed to transcend law itself"278. Para Agamben, "Benjamin definia como 'pura' esta violência que quebra a relação entre violência e direito. Não se trata aqui de uma 'violência criadora' (como é o caso, por exemplo, do poder constituinte que cria um novo direito), mas de uma violência que interrompe e depõe o direito... O que está realmente em questão é, na verdade, a possibilidade de uma ação humana que se situe fora de toda relação com o direito, ação que não ponha, que não execute ou que não transgrida simplesmente o direito. Trata-se do que os franciscanos tinham em mente quando, em sua luta contra a hierarquia eclesiástica, reivindicavam a possibilidade de um uso de coisas que nunca advém direito, que nunca advém propriedade. E talvez 'política' seja o nome dessa dimensão que se abre a partir de tal perspectiva, o nome de livre uso do mundo"279. Para SLAVOJ ZIZEK, "It is mythical violence that demands sacrifice, and holds power over bare life; whereas divine violence is non-sacrificial and expiatory" 280 .

\footnotetext{
${ }^{276}$ AGAMBEN, Giorgio. Homo sacer: o poder soberano e a vida nua I. Tradução de Henrique Burigo. Belo Horizonte: Editora UFMG, 2002, p. 72.

${ }^{277}$ AGAMBEN, Giorgio. Homo sacer: o poder soberano e a vida nua I. Tradução de Henrique Burigo. Belo Horizonte: Editora UFMG, 2002, p. 72.

${ }^{278}$ RASCH, William. Op. cit., p. 98

279 Cf. Giorgio AGAMBEN. In: Política da Profanação. Entrevista ao jornal Folha de São Paulo, de 18.9.2005. Disponível em HTTP://www.geocities.com/vladimirsafatle/vladi081.htm?200722. Acessado em 22.10.2007.

${ }^{280}$ ZIZEK, Slavoj. Violence. New York: Picador, 2008, p. 199.
} 
Resta evidente, destarte, que Benjamin propõe, assim como Agamben o fará, uma reinterpretação da própria natureza do político-jurídico. É nesse sentido que o termo deposição da lei deve ser entendido: uma era em que o direito não seja destruído, mas desativado e deixado inoperante, é dizer, utilizado de uma outra maneira. Muito embora HERBERT MARCUSE ${ }^{281}$, em seu prefácio político de 1966, utilize o termo abolição para questionar o Estado, a nação e o sacrifício humano, parece-nos que ele deve ser entendido no mesmo sentido declinado por Benjamin - deixar inoperante - e, posteriormente, pelo próprio Agamben.

Benjamin pretende provar que uma eliminação não violenta dos conflitos é possível no mundo quando nele reinam a cultura do coração, a cortesia cordial, a empatia, o amor pela paz, a confiança, a amizade ${ }^{282}$. Um domínio onde se suspende a relação meio/fim e lidamos com puros meios. Com razão, para Agamben, “... a tese de Benjamin é que, enquanto a violência mítico-jurídica é sempre um meio relativo a um fim, a violência pura nunca é simplesmente um meio - legítimo ou ilegítimo - relativo a um fim (justo ou injusto)"283. Para SLAVOJ ZIZEK, a violência mítica é um meio para o estabelecimento do império da lei, enquanto a violência divina não serve a qualquer meio, nem mesmo como meio para o estabelecimento da justiça ${ }^{284}$.

Mas, se a violência pura não se encontra numa relação de meio enquanto a um fim, como identificá-la? A resposta, de acordo com Agamben, está no fato de que o meio puro não deve sua pureza a alguma propriedade intrínseca específica que o diferencia dos demais meios, mas à sua relação com estes. Assim, na teoria benjaminiana, a violência pura poderia ser revelada somente como exposição e deposição da relação entre violência e

\footnotetext{
281 “A civilização ocidental sempre glorificou o herói, o sacrifício da vida pela cidade, o Estado, a nação; raramente indagou se a cidade estabelecida, o Estado ou a nação eram dignos de sacrifício. O tabu sobre a indiscutível prerrogativa do todo sempre foi mantido e imposto, e tem sido mantido e imposto tanto mais brutalmente quanto mais se supõe que o todo é composto de indivíduos livres. A questão está sendo agora formulada - formulada de fora - e entendida por aqueles que se recusam a fazer o jogo dos afluentes; é a questão de saber se a abolição desse todo não será uma precondição para a emergência de uma cidade, Estado, nação, verdadeiramente humanos". MARCUSE, Herbert. Eros e civilização: uma interpretação filosófica do pensamento de Freud. 8. ed. Tradução de Álvaro Cabral. Rio de Janeiro: LTC, 1999, p. 19. ${ }^{282}$ Cf. Jacques DERRIDA. Op. cit., p. 113-114.

${ }^{283}$ AGAMBEN, Giorgio. Estado de exceção. Tradução de Iraci D. Poleti. São Paulo: Boitempo, 2004, p. 95.

${ }^{284}$ Cf. Slavoj ZIZEK. Violence. New York: Picador, 2008, p. 199-200.
} 
direito $^{285}$, bem como o estado de exceção que os une em Agamben, rumo a uma inatividade do próprio direito. Dessa maneira, abrir-se-ia, finalmente, uma passagem para a justiça $^{286}$. Ao analisar o trabalho de Benjamin, OLGÁRIA MATOS descreve que:

"Eis por que a cena contemporânea suscita refletir acerca do eclipsamento democrático na relação entre modernidade, globalização e estado de exceção. A modernidade é a exceção em permanência: 'o estado de exceção', anotou W. Benjamin, 'é a regra'. Em suas reflexões sobre o fascismo e a guerra, o filósofo enfatiza as afinidades entre cultura política e científica, e estado de exceção, a partir do jurista Carl Schmitt, 'é soberano aquele que decide o estado de exceção'. Benjamin o analisa segundo o direito público. O estado de exceção é inconsciente de si pois mobiliza conceitos cujas raízes e fundamentos permanecem escondidos em razão de uma amnésia social: pertencem ao campo teológico secularizado. Eis por que Schmitt escreve que o estado de exceção na política corresponde ao milagre na teologia, é 'intervenção' divina ou domínio do acaso - em ambas as circunstâncias a política é transcendência. $\mathrm{O}$ descrédito no parlamento, nas instituições políticas de representação social, nas leis, na punição de sua violação, em sua aplicabilidade faz com que, hobbesianamente, troque-se a liberdade por segurança., 287

Assim, a violência que Benjamin define como divina não se situa na dialética entre norma e estado de exceção enquanto fenômenos distintos, mas numa zona na qual não é mais possível distinguir entre exceção e regra, uma violência que é “... no direito, uma instância de não-direito" ${ }^{288}$, “... é uma anomalia no interior da juridicidade com que parece romper. A ruptura da relação é aqui, a relação" 289 .

De outra forma, a dialética entre violência que põe o direito e violência que conserva o direito não seria rompida, e a decisão soberana continuará a aparecer “.... simplesmente como o meio em que se realiza a passagem de uma a outra (neste sentido,

\footnotetext{
${ }^{285}$ Cf. Giorgio Agamben. Estado de exceção. Tradução de Iraci D. Poleti. São Paulo: Boitempo, 2004, p. 9596.

${ }^{286}$ Cf. Giorgio AGAMBEN. Estado de exceção. Tradução de Iraci D. Poleti. São Paulo: Boitempo, 2004, p. 98.

${ }^{287}$ MATOS, Olgária. Modernidade: república em estado de exceção. In: Revista da Universidade de São Paulo. Setembro/outubro/novembro 2003. São Paulo: USP, CCS, 1989, p. 46.

${ }^{288}$ Cf. Jacques DERRIDA. Op. cit., p. 84.

${ }^{289}$ Cf. Jacques DERRIDA. Op. cit., p. 91.
} 
pode-se dizer que a violência soberana põe o direito, já que afirma a licitude de um ato de outra forma ilícito, e simultaneamente o conserva, já que o conteúdo do novo direito é somente a conservação do velho)" ${ }^{290}$. Por isso, Benjamin pode dizer que a violência divina - na medida em que, digamos, ela não é uma outra espécie de violência, mas apenas o dissolvimento do nexo entre violência e direito - não põe, nem conserva o direito, mas o depõe ${ }^{291}$ (Benjamin può dire che la violenza divina non pone né conserva il diritto, ma lo depone): non/né.

Entretanto, em que pesem essas considerações, Agamben parece sugerir em sua obra que a solução proposta por Benjamin é demasiadamente indefinida, assim como, na interpretação de ARNE DE BOEVER, “Agamben finds Benjamin's essay problematic, however, in that it leaves the figure largerly undefined, suggesting even that it can't be recognised in the concrete case ${ }^{, 292}$. Realmente, os alicerces e o raciocínio de suas teses são compreensíveis, resta sabermos como as executar.

Exposta, em termos gerais - mas suficientes aos propósitos aqui perquiridos -, a violência benjaminiana, passemos a analisar o outro pólo do debate Benjamin-Schmitt. Agamben interpreta em Schmitt um esforço para “... trazer tal violência [divina] para um contexto jurídico"293 por meio de uma unidade política e de uma homogeneidade à luz de um liberalismo autoritário tutelado por um Estado forte que busca a neutralização de quaisquer conflitos:

"O estado de exceção é o espaço em que ele [Schmitt] procura capturar a idéia benjaminiana de uma violência pura e inscrever a anomia no corpo mesmo do nomos. Segundo Schmitt, não seria possível existir uma violência pura, isto é, absolutamente fora do direito, porque, no estado de exceção, ela está incluída no direito por sua própria exclusão. O estado de exceção é, pois, o dispositivo por meio do qual Schmitt responde à afirmação benjaminiana de uma ação humana inteiramente anômica.",294

\footnotetext{
${ }^{290}$ AGAMBEN, Giorgio. Homo sacer: o poder soberano e a vida nua I. Tradução de Henrique Burigo. Belo Horizonte: Editora UFMG, 2002, p. 72.

${ }^{291}$ Cf. Giorgio AGAMBEN. In: Homo sacer: o poder soberano e a vida nua I. Tradução de Henrique Burigo. Belo Horizonte: Editora UFMG, 2002, p 73.

${ }^{292}$ BOEVER, Arne de. Op. cit., p. 82.

${ }^{293}$ AGAMBEN, Giorgio. Estado de exceção. Tradução de Iraci D. Poleti. São Paulo: Boitempo, 2004, p. 85.

${ }^{294}$ AGAMBEN, Giorgio. Estado de exceção. Tradução de Iraci D. Poleti. São Paulo: Boitempo, 2004, p. 86.
} 
O telos específico da teoria schmittiana seria, assim, exatamente o de tornar possível uma articulação entre o estado de exceção e a ordem jurídica ${ }^{295}$, “de modo que o poder seja, ao mesmo tempo, aquilo que define a soberania como entidade jurídica e como fato político" ${ }^{296}$. É assim que, diante do desmoronamento das democracias européias, a teoria do estado de exceção, inicialmente estruturada em Die Diktatur, teve um momento de especial sucesso sob a forma de ditadura constitucional ${ }^{297}$, de acordo com Agamben $^{298}$.

Nessa obra, Schmitt qualifica a ditadura comissária e a ditadura soberana: a ditadura comissária, fundada num pouvoir constiué, é o instituto pelo qual o ditador comissário aceita um cargo para realizar uma ou mais funções específicas e solucionar uma crise - um ofício constitucional, ocasião em que a lei pode ser suspensa até que volte a normalidade -, é dizer, uma ditadura para salvaguarda da ordem constitucional e, destarte, uma ditadura constitucional; já a ditadura soberana é fundada num pouvoir constituant, isto é, advinda do povo e de natureza duradoura ${ }^{299}$, ou seja, uma ditadura inconstitucional, que leva à derrubada da ordem constitucional.

Na ditadura comissária, a aplicação da lei é suspensa para proteger sua própria existência, mas sua vigência permanece. Há uma distinção do momento da aplicação da norma em relação à autonomia da norma como tal. Para vincular o estado de exceção ao direito, Schmitt se baseia, portanto, na distinção entre normas de direito e técnicas de sua aplicação, ou normas de realização de direito. Representa “... pois, um estado da lei em que esta não se aplica, mas permanece em vigor ${ }^{\prime 300}$.

${ }^{295}$ Cf. Giorgio AGAMBEN. Estado de exceção. Tradução de Iraci D. Poleti. São Paulo: Boitempo, 2004, p. 54.

${ }^{296}$ Cf. Tercio Sampaio FERRAZ JR. Estudos de filosofia do direito: reflexões sobre o poder, a liberdade, a justiça e o direito. 3 ed. São Paulo: Atlas, 2009, p. 56.

${ }^{297}$ Gilberto BERCOVICI esclarece que “... a ditadura do presidente, defendida por Schmitt no início da república de Weimar, é uma ditadura comissária, embora, ao decidir sobre o estado de exceção do artigo 48, o presidente exercite um poder soberano sem sê-lo. No entanto, na fase crítica, quando Schmitt passa a entender que a constituição, por suas contradições internas, não era mais passível de salvação, a ditadura comissária e a ditadura soberana se tornam indistintas, com o presidente assumindo a tarefa de, por meio do estado de exceção, reconstruir soberanamente uma nova ordem constitucional para a Alemanha". In: Soberania e constituição: para uma crítica do constitucionalismo. São Paulo: Quartier Latin, 2008, p. 314-315. A posição de Bercovici tende assim a corroborar o entendimento de Agamben, para quem a diferença entre ditadura comissária e ditadura soberana não é de natureza, mas de grau, como veremos abaixo.

${ }^{298}$ AGAMBEN, Giorgio. Estado de exceção. Tradução de Iraci D. Poleti. São Paulo: Boitempo, 2004, p. 17.

${ }^{299}$ Vale notar que ditadura soberana não se confunde com soberania, que é em si mesma independente em Schmitt.

${ }^{300}$ AGAMBEN, Giorgio. Estado de exceção. Tradução de Iraci D. Poleti. São Paulo: Boitempo, 2004, p. 58. 
Já na ditadura soberana, não há uma mera suspensão da lei com base num direito nela previsto, mas a criação de um estado em que se torne possível a instauração de uma nova lei. Neste caso, Schmitt vincula o estado de exceção à dialética entre poder constituinte e poder constituído e, notadamente, ao fenômeno do poder constituinte como mínimo de constituição ${ }^{301}$. A ditadura soberana representa, assim, “... um estado em que esta [nova constituição] se aplica, mas não está formalmente em vigor" ${ }^{302}$.

De acordo com Schmitt, destarte, a ditadura não é o oposto da democracia, mas sua verdadeira face. Analisando as doutrinas de Herbert Tingsten, Frederick Watkins, Carl Friedrich e Clinton Rossiter - e declarando que todos eles têm, de certa forma, muito em comum com a teoria schmittiana -, Agamben revela que o termo ditadura constitucional sugere a extensão dos poderes do executivo no âmbito legislativo por meio da promulgação de decretos e disposições à luz da lógica e da delegação contidas em dispositivos como o artigo 48 da Constituição de Weimar.

Essa delegação - do Parlamento ao governo - justificar-se-ia em situações anormais que ameacem o equilíbrio dos poderes, a segurança pública e/ou a ordem e, por essa mesma razão, seriam teoricamente compatíveis com as constituições democráticas, assim como seu uso provisório seria não somente um direito do Estado, mas um dever inerente à sua própria condição política. Trata-se de uma medida para, em teoria e na prática, simplesmente neutralizar o perigo.

Cabe adiantar que Agamben, além de criticar a legitimidade de uma "democracia protegida" ${ }^{303}$ (democrazia protetta), sustentará igualmente que o exercício sistemático desses dispositivos de plenos poderes funciona - em razão da subjetividade de seus fundamentos de absoluta necessidade e de caráter temporário - como uma fase de transição à instauração de um regime totalitário, de maneira que se torna inevitavelmente prática duradoura de governo. Não por outra razão o “... Terceiro Reich pode ser considerado, do ponto de vista jurídico, como um estado de exceção que durou doze anos" ${ }^{\text {304 }}$. Isto é,

\footnotetext{
${ }^{301}$ Cf. Carl SCHMITT. Teoría de la Constitución. Tradução de Francisco Ayala. Madrid: Alianza Editorial, 1982, p. 109.

${ }^{302}$ AGAMBEN, Giorgio. Estado de exceção. Tradução de Iraci D. Poleti. São Paulo: Boitempo, 2004, p. 58.

${ }^{303}$ AGAMBEN, Giorgio. Estado de exceção. Tradução de Iraci D. Poleti. São Paulo: Boitempo, 2004, p. 29.

${ }^{304}$ AGAMBEN, Giorgio. Estado de exceção. Tradução de Iraci D. Poleti. São Paulo: Boitempo, 2004, p. 13.
} 
Agamben vislumbra uma impossibilidade de estabelecer técnicas que freiem a passagem da ditadura constitucional à ditadura inconstitucional, pois não se trata tanto da natureza do instituto, mas de seu grau.

Se, em Die Diktatur, a ditadura aparece como principal figura do estado de exceção - a ditadura soberana seria sua “... massa crítica ou ponto de fusão"305 -, Schmitt teria percebido que essas conceituações não seriam suficientes para qualificar a sua progressiva exacerbação na República de Weimar, adequando sua teoria à distinção entre norma (norm) e decisão (entscheidung, dezision).

É assim que, em Politische Theologie, o termo ditadura pode ser substituído, segundo Agamben, por estado de exceção (Ausnahmezustand). Schmitt dirá que o sistema constitucional é válido somente se fundado sobre uma decisão soberana, conceito esse tipificado na frase inaugural de Teologia Politica $I^{306}$ : “... soberano é quem decide sobre o estado de exceção" ${ }^{\text {307, }}$ que, para RONALDO PORTO MACEDO JR., gera uma série de equívocos quanto à intenção de seu criador ${ }^{308}$. A decisão é o ato fundador e a vontade do soberano quanto ao princípio da ordem que, sustentado sobre uma exceção - cuja paradoxal estrutura significa que estamos compelidos a obedecer a ordem -, torna localizável e justifica a origem da obrigação política. Elucida-se, assim, porque a teoria do estado de exceção schmittiana é apresentada igualmente como uma teoria da soberania.

Essa concepção decisionista, segundo Schmitt, foi inicialmente desenvolvida por Jean Bodin e posteriormente por Thomas Hobbes, que teria definido o conceito clássico de decisionismo no século XVII. A bem da verdade, a própria definição de ditadura em Schmitt surge a partir da distinção entre soberania e ditadura elaborada por $\operatorname{Bodin}^{309}$, justamente porque “... a razão que levou Schmitt ao conceito de Bodin é que este

\footnotetext{
${ }^{305}$ AGAMBEN, Giorgio. Estado de exceção. Tradução de Iraci D. Poleti. São Paulo: Boitempo, 2004, p. 53.

${ }^{306}$ A obra Teologia Política é composta por dois trabalhos escritos em momentos diferentes (1922 e 1970), mas a questão da soberania é apresentada no primeiro deles. In: SCHMITT, Carl. Teologia Política. Tradução de Elisete Antoniuk. Belo Horizonte: Del Rey, 2006.

${ }^{307}$ SCHMITT, Carl. Teologia Política. Belo Horizonte: Del Rey, 2006, p. 7.

${ }^{308}$ Para Ronaldo Porto Macedo Júnior, esse slogan schmittiano "tem gerado uma série de equívocos por parte dos intérpretes que vêem em Schmitt um teórico do Estado de Exceção, esquecendo-se de sua preocupação científica de explicar o fenômeno jurídico e explorar o conceito de exceção, como ele próprio diz, enquanto um conceito-limite para a explicação do direito". In: Carl Schmitt e a fundamentação do direito. São Paulo: Max Limonad, 2001, p. 114.

${ }^{309}$ Cf. Ronaldo Porto MACEDO JR. Op. cit., p. 59.
} 
permitiria estabelecer a soberania como uma unidade indivisivel e decidir a questão do poder num Estado" ${ }^{310}$.

De acordo com Schmitt, o que está na origem do ordenamento jurídico e do próprio Estado é uma decisão soberana, isto é, uma decisão que, visando agrupar o povo ${ }^{311} \mathrm{em}$ torno de um determinado conteúdo homogêneo e o defender daqueles a ele contrários adversários políticos -, discrimina quem é amigo e quem é inimigo (Freund/Feind). É nesse sentido que Carl Schmitt interpreta Hobbes, uma de suas principais fontes de literatura do Estado: a efetiva liberdade social só é possível a partir de uma decisão soberana que saberá distinguir o amigo do inimigo para sua autopreservação. Em última análise, o que era fundamental para frear a guerra de todos contra todos era igualmente basilar para não submeter o Reich ao subjugo do inimigo.

Schmitt parece, assim, substituir ${ }^{312}$ - em termos, porquanto a articulação das ditaduras criou a possibilidade de juridicizar o estado de exceção ${ }^{313}$ - a ancoragem do estado de exceção nas ditaduras comissária e soberana para fundamentá-la na figura do soberano, ou melhor, da decisão soberana. Assim como na ditadura comissária a aplicação da norma era suspensa para sua própria preservação, o estado de exceção abalizado na decisão soberana “... separa, pois, a norma de sua aplicação para tornar possivel a aplicação. Introduz no direito uma zona de anomia para tornar possivel a normatização efetiva do real". É sob essas premissas que Agamben conclui que o estado de exceção na doutrina schmittiana pode ser definido como "... o lugar em que a oposição entre a norma e a sua realização atinge a máxima intensidade ${ }^{\text {,314. }}$.

Isso significa que Schmitt entende que o Estado pressupõe o político, quer dizer, da definição de político depende o Estado, e não o contrário, já que auctoritas, non veritas facet legem, frase contida em Leviathan e abraçada por Schmitt: o processo de formação da

\footnotetext{
${ }^{310}$ SOLON, Ari Marcelo. Teoria da soberania como problema da norma jurídica e da decisão. Porto Alegre: Sergio Antonio Fabris Editor, 1997, p. 80.

${ }^{311}$ Impende salientar que o povo, em Schmitt, encontra-se acima da constituição, de maneira que o poder constituinte nunca se esgota no texto constitucional, mas por aclamações populares.

${ }^{312}$ Cf. Giorgio AGAMBEN. In: Estado de exceção. Tradução de Iraci D. Poleti. São Paulo: Boitempo, 2004, p. 86.

${ }^{313}$ Cf. Giorgio AGAMBEN. In: Estado de exceção. Tradução de Iraci D. Poleti. São Paulo: Boitempo, 2004, p. 57.

${ }^{314}$ AGAMBEN, Giorgio. Estado de exceção. Tradução de Iraci D. Poleti. São Paulo: Boitempo, 2004, p. 58.
} 
identidade implica na existência de uma decisão política sobre quem é o inimigo, muito embora a decisão permaneça no "âmbito jurídico"315.

De acordo com Gilberto Bercovici, “... de conceito do direito público, o Estado, para Schmitt, se tornou uma questão sobre a essência do político, o Estado deveria ser pensado a partir e em função do político, sem o qual perderia o sentido"316. O soberano está fora da ordem jurídica normalmente válida e, entretanto, pertence a ela, uma vez que é responsável pela decisão quanto à sua suspensão. Isto é, “... o soberano se coloca fora da ordem jurídica normalmente vigente, porém a ela pertence, pois ele é competente para a decisão sobre se a Constituição pode ser suspensa in toto"317.

"Estar-fora e, ao mesmo tempo, pertencer: tal é a estrutura topológica do estado de exceção, e apenas porque o soberano que decide sobre a exceção é, na realidade, logicamente definido por ela em seu ser, é que ele pode também ser definido pelo oximoro êxtase-pertencimento." 318

O soberano é, portanto, aquele que instaura a ordem num caos, ainda que não uma ordem jurídica, quer dizer, uma mera normalidade, uma pacificação. A decisão soberana, política e fundamental, nasce necessariamente de uma decisão arbitrária e ilimitada ${ }^{319}$ inclusive com relação a eventual direito natural -, porquanto a exceção é imprevisível: ela instaura a ordem na qual atuarão as instituições e o próprio direito, pois é o soberano que “... decide tanto sobre a ocorrência do estado de necessidade extremo, bem como sobre o que se deve fazer para saná-lo"320. Quer dizer, “... o estado de exceção existe para criar a situação na qual o direito poderá valer ${ }^{\prime 321}$.

Nesse sentido, Schmitt afirma que: “... a norma necessita de um meio homogêneo. Essa normalidade fática não é somente um 'mero pressuposto' que o jurista pode ignorar.

\footnotetext{
${ }^{315}$ SCHMITT, Carl. Teologia política. Tradução de Elisete Antoniuk. Belo Horizonte: Del Rey, 1006, p. 13. ${ }^{316}$ BERCOVICI, Gilberto. Constituição e estado de exceção permanente: atualidade de Weimar. Rio de Janeiro: Azougue Editorial, 2004, p. 69.

${ }^{317}$ SCHMITT, Carl. Teologia política. Tradução de Elisete Antoniuk. Belo Horizonte: Del Rey, 1006, p. 8. ${ }^{318}$ AGAMBEN, Giorgio. Estado de exceção. Tradução de Iraci D. Poleti. São Paulo: Boitempo, 2004, p. 57.

${ }^{319}$ Para Gilberto BERCOVICI, de fato o estado de exceção schmittiano, justamente por se justificar pela situação de ameaça à unidade política, não pode ser limitado. In: Constituição e estado de exceção permanente: atualidade de Weimar. Rio de Janeiro: Azougue Editorial, 2004, p. 66.

${ }^{320}$ SCHMITT, Carl. Teologia política. Tradução de Elisete Antoniuk. Belo Horizonte: Del Rey, 1006, p. 8. ${ }^{321}$ BERCOVICI, Gilberto. Constituição e estado de exceção permanente: atualidade de Weimar. Rio de Janeiro: Azougue Editorial, 2004, p. 66.
} 
Ao contrário, pertence à sua validade imanente. Não existe norma que seja aplicável ao caos. A ordem deve ser estabelecida para que a ordem jurídica tenha um sentido" ${ }^{\text {322 }}$. A decisão soberana seria assim o elemento que une a ordem normativa e a vida em Schmitt, independentemente de qualquer critério de legalidade. Para Vera KARAM DE CHUEIRI:

"Na lógica schmittiana, a exceção é a condição de possibilidade da norma jurídica e o próprio significado da autoridade do Estado. Eis a situação paradoxal, segundo a qual o soberano através da exceção cria a situação de que o Direito precisa para poder existir, a qual, ironicamente, é a situação de suspensão do próprio direito." ${ }^{323}$

Portanto, o estado de exceção schmittiano não somente dá validade à ordem jurídica, mas torna possível a instituição de um lócus para o seu estabelecimento a partir do extremus necessitatis casus ${ }^{324}$. Por conseguinte, a soberania é o conceito limite ${ }^{325}$ da ordem e da exceção, uma vez que o soberano decide se uma situação confrontada é realmente uma exceção ou ordem normal - caso em que permaneceria dormente -, de maneira que a própria soberania se traduz nessa decisão. Em Schmitt, a decisão não concerne uma decisão sobre o fato ou sobre o direito, mas à própria relação entre eles.

É importante notar, destarte, que Schmitt, ao definir a soberania a partir da localização da exceção (Ortung) e da ordem (Ordnung), está criticando a teoria liberal do Estado, a qual equaciona soberania e Estado de Direito. Há, também, em Schmitt, uma crítica ao positivismo jurídico de Hans Kelsen, na medida em que é o soberano, e não a norma jurídica, que constitui a suprema autoridade ${ }^{326}$. Isso se torna evidente quando Schmitt declara, como visto acima, que "Essa normalidade fática não é somente um 'mero

\footnotetext{
${ }^{322}$ SCHMITT, Carl. Teologia política. Tradução de Elisete Antoniuk. Belo Horizonte: Del Rey, 1006, p. 13.

${ }^{323}$ CHUERI, Vera Karam de. Agamben e o estado de exceção como zona de indeterminação entre o político e o jurídico. In: FONSECA, Ricardo Marcelo (org.). Crítica da Modernidade: diálogos com o Direito. Florianópólis: Fundação Boiteux, 2005, p. 96.

${ }^{324}$ Cf. SCHMITT, Carl. Teologia política. Tradução de Elisete Antoniuk. Belo Horizonte: Del Rey, 1006, p. 11.

${ }^{325}$ Para Steven DECAROLI, “A necessary condition for the possibility of banishment is a boundary - real or virtual, terrestrial or divine - outside of which one may be abandoned. It is not by coincidence that we see this same conceptual demand also appear in the modern definition of sovereignty, where the twin elements of political territory and a bounded territorial jurisdiction are umited." In: Boundary stones: Giorgio Agamben and the field of sovereignty. In: CALARCO, Matthew; DECAROLI, Steven (ed.). Giorgio Agamben: sovereignty and life. Stanford, California: Stanford University Press, 2007, p. 47.

${ }^{326}$ Cf. CHUERI, Vera Karam de. Op. cit., p. 100.
} 
pressuposto' que o jurista pode ignorar", fazendo aparente alusão à Grundnorm kelseniana.

De fato, Kelsen defende, sob o manto do positivismo jurídico, que a soberania não cabe no âmbito da ciência jurídica ${ }^{327}$, porquanto o direito é reduzido a um sistema metodologicamente unitário de normas afastadas do universo dos valores e das forças sociais comuns, quer dizer, de qualquer conteúdo axiológico, bem como de um eventual direito natural. Daí a advertência que HANS KELSEN faz no prefácio à primeira edição da Teoria Pura do Direito:

“A luta não se trava na verdade - como as aparências sugerem - pela posição da Jurisprudência dentro da ciência e pelas conseqüências que daí resultam, mas pela relação entre a ciência jurídica e a política, pela rigorosa separação entre uma e outra, pela renúncia ao enraizado costume de, em nome da ciência do Direito e, portanto, fazendo apelo a uma instância objetiva, advogar postulados políticos que apenas podem ter um caráter altamente subjetivo, mesmo que surjam, com a melhor das boas fés, como ideal de uma religião, de uma nação ou de uma classe., 328

Kelsen delimita a ciência jurídica como unidade, excluindo a doutrina da soberania de seu âmbito, muito embora, como bem adverte ARI MARCELO SOLON em sua leitura de Kelsen, “... com relação à soberania, como ilimitaçao do poder, conclui-se que ela é mal posta, pois, por mais ilimitado que seja o poder, sempre será um poder jurídico. Mesmo que o governante autocrático pretenda elevar-se acima da ordem jurídica, suas ordens somente serão válidas graças à pressuposição de uma norma originária" ${ }^{329}$.

De acordo com um de seus adeptos italianos, Norberto BobBio, o único poder soberano - e talvez esse não seja o melhor termo a ser utilizado - que se pode falar em Kelsen à luz de sua rigorosa redução de Estado a ordenamento jurídico é aquele de criar e aplicar o direito num território e para um povo, “... poder que recebe sua validade da

327 "Do fato de algo ser não pode seguir-se que algo deve ser; assim como do fato de algo dever ser se não pode seguir que algo é“. KELSEN, Hans. Teoria pura do direito, 6. ed. Coimbra: Armênio Amado, 1984, p. 267.

${ }^{328}$ KELSEN, Hans. Teoria pura do direito. Tradução de João Baptista Machado. 6. ed. São Paulo: Martins Fontes, 1998, p. XII.

${ }^{329}$ SOLON, Ari Marcelo. Op. cit., p. 52-53. 
norma fundamental e da capacidade de se fazer valer recorrendo inclusive, em última instância, à força" ${ }^{330}$ : segundo o filósofo italiano, em sua Teoria Geral do Direito e do Estado, norma e poder são duas faces da mesma moeda, faces essas que são colocadas em relevo conforme o primado do poder sobre a norma ou vice-versa ${ }^{331}$, ou seja, conforme o ponto de partida, da norma inferior à norma fundamental ou do poder soberano aos planos inferiores:

"Em uma teoria normativa rigorosa como a de Kelsen, a norma fundamental é o conceito exatamente simétrico ao de poder soberano. A norma fundamental é a norma das normas, assim como o poder soberano é o poder dos poderes. São perfeitamente simétricos esses dois conceitos, uma vez que a norma fundamental e o poder soberano têm a mesma função, a de fechar o sistema: a primeira em uma teoria jurídica; a segunda, em uma teoria política, do Estado.",332

Entretanto, no último período de sua carreira, quando morava nos Estados Unidos da América, Kelsen modificou profundamente sua concepção, aproximando-se do realismo jurídico norte-americano ${ }^{333}$, notadamente a partir de 1963, quando já passava de 80 anos: a Grundnorm deixa de ser um pressuposto de pensamento e passa a ser o produto fictício de uma vontade fictícia. A norma fundamental torna-se um ato ficcional de uma vontade ficcional que encontra sua realidade empírica no fato de que o sistema avança pela vontade, por parte das autoridades, de agir como autoridades jurídicas, de acordo com WAYNE MORRISON ${ }^{334}$.

Kelsen parece repensar sua teoria da norma fundamental para afirmar, de acordo com Gilberto BerCOVICI, que “... a norma fundamental se refere diretamente a uma constituição determinada, ou seja, a constituição é a verdadeira norma fundamental de um

\footnotetext{
${ }^{330}$ BOBBIO, Norberto. Estado, governo, sociedade: por uma teoria geral da política. Tradução de Marco Aurélio Nogueira. Rio de Janeiro: Paz e Terra, 1987, p. 94.

${ }^{331}$ Cf. Norberto BOBBIO. In: Direito e poder. Tradução de Nilson Moulin. São Paulo: UNESP, 2008, p. 170.

${ }^{332}$ Cf. Norberto BOBBIO. In: Direito e poder. Tradução de Nilson Moulin. São Paulo: UNESP, 2008, p. 171.

${ }^{333}$ Cf. Jean-Cassier BILLIER e Aglaé MARYOLI. In: História da filosofia do direito. Tradução de Maurício de Andrade. Barueri: Manole, 2005, p. 225-226.

${ }^{334}$ MORRISON, Wayne. Filosofia do direito: dos gregos ao pós-modernismo. Traduçao de Jefferson Luiz Camargo. São Paulo: Martins Fontes, 2006, p. 405.
} 
ordenamento jurídico. A soberania, assim, não pertence ao ordenamento, mas à constituição. Kelsen, na expressão de Frosini, vai da negação da soberania à soberania da constituição",335.

Em Schmitt, entretanto, o ordenamento jurídico não pode ser assumido como um sistema de normas sem fonte externa e fundamentado em si mesmo; supera-se a dicotomia kantiana entre Sein e Sollen. De fato, o que separa profundamente Schmitt e Kelsen não é tanto um suposto desacordo acerca da normatividade do direito, ou seja, acerca da capacidade do direito de expressar um dever-ser, mas sim a convicção schmittiana da inseparabilidade entre esse dever-ser e ser, de acordo com o italiano GiANLUIGI PALOMBELlA $^{336}$. Em Schmitt, o direito está sempre ligado ao Sein, ao político, ao poder, a uma decisão, e é por eles essencialmente marcado a ponto de não se poder fazer um estudo que deles prescinda: a unidade do Reich não se apóia nos dispositivos legais ou sua vigência, mas na existência política do povo alemão. WILLIAM SCHEUERMAN identifica a divergência entre Kelsen e Schmitt em sua obra Between the norm and the exception:

"Schmitt's concept of sovereignty sought to free voluntas from ratio; Kelsen inverts this view and seeks to drive an empirical account of the problem of voluntas (and concrete power relations) from the field of legal science altogether., 337

"Kelsen busca en el formalismo el refugio de posibles verdades jurídicas a priori, en tanto Schmitt va en pos de lo concreto y frente a la 'ratio' y al 'nomos' impersonal, afirma el caràcter personalista de la decisión" ${ }^{\text {338 }}$. Ou seja, Schmitt pretende uma vontade sem norma, enquanto Kelsen busca uma norma sem vontade. Daí pensar que toda ordem schmittiana resta sobre uma decisão e que, portanto, a soberania não é uma questão jurídica, muito embora esteja no âmbito jurídico, mas política, que tem a ver com o ato de decidir sobre a situação ou estado de exceção, requisitando aí a ação humana do soberano.

\footnotetext{
${ }^{335}$ BERCOVICI, Gilberto. Soberania e constituição: para uma crítica do constitucionalismo. São Paulo: Quartier Latin, 2008, p. 22.

${ }^{336}$ PALOMBELA, Gianluigi. Filosofia do direito. Tradução de Ivone Benedeti. São Paulo: Martins Fontes, 2005, p. 180-200.

337 SCHEUERMAN, William. E. Between the norm and the exception: the Frankfurt School and the rule of law. Cambridge and London: The MIT Press, 1997, p. 178.

${ }^{338}$ CRACOGNA, Dante. Acerca del concepto de constitucion en Carl Schmitt y Hans Kelsen. In: Revista de la Facultad de Derecho y Ciencias Políticas, Medellin-Columbia, n. 75, año 1986, segundo semestre, p. 83.
} 
Não uma ratio, mas uma voluntas. Por essa razão, Schmitt busca “... limitar o parlamento ao conceito liberal-constitucional de lei, contrapondo-se aos autores positivistas, definindo um conceito político de lei, em que inclui as medidas do poder executivo. $O$ parlamento, para ele, deve se limitar às leis gerais, limitando a esfera de atuação parlamentar e garantindo a supremacia do executivo em legislação econômica"339.

Poder-se-ia dizer, de conseguinte, que a soberania schmittiana - que logo se reduziria ao Movimento ${ }^{340}$ do Führer na emergência do Terceiro Reich - é um fenômeno externo ao ordenamento, às regras do jogo jurídico: “... soberanas não são as regras do jogo, soberano é quem estabelece o início do jogo jurídico" ${ }^{\text {341 }}$. A exceção só pode ser concebida na esfera da decisão, segundo Schmitt, isto é, de um evento real e histórico e não na esfera neutra da lei ${ }^{342}$ : “... o que é normal nada prova, a exceção comprova tudo; ela não somente confirma a regra, mas esta vive da exceção",343.

De acordo com OlgáRIA MATOS, “... a modernidade, schmittiana, converte o parlamentarismo em ilusão - a de que a 'conversação perpétua' leva, por si só, à 'paz perpétua'. E, desqualificando as instituições democráticas de representação, o poder econômico faz da corrupção um 'negócio', uma vez que desloca a atenção para a classe política sob suspeita" ${ }^{344}$. Para a filósofa:

"Schmitt é o grande teórico dos ressentimentos de toda uma geração, ressentimento em relação à democracia de massa, à República, à modernidade política. O artigo 48 de sua Constituição garantia ao presidente suspender as garantias constitucionais. Aproximam-se Benjamin e Schmitt no reconhecimento de uma fusão entre modernidade política, econômica e científica e a noção de progresso, Schmitt convencido da ilegitimidade das democracias liberais, Benjamin concentrando sua atenção na modernidade do fascismo, em estreita relação com a sociedade industrial contemporânea. Razão

\footnotetext{
${ }^{339}$ BERCOVICI, Gilberto. Soberania e constituição: para uma crítica do constitucionalismo. São Paulo: Quartier Latin, 2008, p. 304.

${ }^{340}$ A unidade política do nazismo era dividida em Estado, Movimento e Povo. Estado era a figura estática, o Movimento a figura política dinâmica, e o Povo a área não política. Embora num mesmo nível, Movimento conduzia Estado e Povo na lógica schmittiana, restando evidente a submissão do Estado ao político.

${ }^{341}$ MACEDO JR., Ronaldo Porto. Op. cit., p. 116.

${ }^{342}$ Cf. CHUERI, Vera Karam de. Op. cit., p. 97.

${ }^{343}$ SCHMITT, Carl. Teologia política. Tradução de Elisete Antoniuk. Belo Horizonte: Del Rey, 1006, p. 15.

${ }^{344}$ MATOS, Olgária. Op. cit., p. 46.
} 
pela qual o filósofo propõe a 'organização do pessimismo': 'pessimismo em todas as frentes'... Desconfiança quanto ao destino da literatura, desconfiança quanto ao destino do homem europeu, mas sobretudo uma tripla desconfiança diante de qualquer acomodação: entre as classes, entre os povos, entre os indivíduos. E confiança ilimitada apenas na I. G. Farben e no aperfeiçoamento pacífico da Luftwaffe.",345

Porém, enquanto Agamben parece corroborar os fundamentos da concepção de estado de exceção schmittiano em Homo sacer, principalmente na primeira parte intitulada Logica della sovranità, há uma clara mudança de posição ${ }^{346}$ em Estado de exceção. É o que passaremos a estudar.

\subsubsection{Agamben e os gigantes}

De fato, ao considerar a teoria da soberania de Schmitt, Agamben observa que “... $a$ exceção que define a estrutura da soberania é, porém, mais complexa. Aquilo que está fora vem aqui incluído não simplesmente através de uma interdição ou de um internamento, mas suspendendo a validade do ordenamento, deixando, portanto, que ele se retire da exceção, a abandone. Não é a exceção que se subtrai à regra, mas a regra que, suspendendo-se, dá lugar à exceção e somente desse modo se constituí como regra, mantendo-se em relação com aquela"347.

Agamben parece, a partir de então, negar a teoria schmittiana - assim como afirmará que a soberania não é "a norma suprema do ordenamento jurídico (Kelsen)"348 ao declarar que “... o estado de exceção não é uma ditadura (constitucional ou inconstitucional, comissária ou soberana), mas um espaço vazio de direito, uma zona de anomia em que todas as determinações jurídicas - e, antes de tudo, a própria distinção

\footnotetext{
${ }^{345}$ MATOS, Olgária. Op. cit., p. 46.

${ }^{346}$ A bem da verdade, Estado de exceção esclarece e estende a caracterização de soberania, lei e violência legal que Agamben inicialmente elabora em Homo sacer. No primeiro texto, ele descreve a condição moderna da lei como força sem significância, uma condição que é efetivamente equivalente ao abandono, em que o sujeito da lei é inteiramente dado à violência da lei e simultaneamente privado de sua proteção.O outro texto, por sua vez, elabora a tese partindo da essencial contiguidade entre o estado de exceção e a soberania estabelecida por Schmitt em Teologia política.

${ }^{347}$ AGAMBEN, Giorgio. Homo sacer: o poder soberano e a vida nua I. Tradução de Henrique Burigo. Belo Horizonte: Editora UFMG, 2002, p. 18.

348 AGAMBEN, Giorgio. Homo sacer: o poder soberano e a vida nua I. Tradução de Henrique Burigo. Belo Horizonte: Editora UFMG, 2002, p. 35.
} 
entre público e privado - estão desativadas... falaciosas são as doutrinas que, como a de Schmitt, tentam inscrever indiretamente o estado de exceção num contexto jurídico, baseando-o na divisão entre normas de direito e normas de realização de direito, entre poder constituinte e poder constituído, entre norma e decisão" ${ }^{349}$. Isto é, enquanto o estado de exceção schmittiano pertence ao âmbito jurídico, em Agamben ele é um vazio de direito.

Para o filósofo italiano, em que pesem os esforços de Schmitt, “... a dupla categorial fundamental da política ocidental não é aquela amigo-inimigo, mas vida nuaexistência política, zoé-bíos, exclusão-inclusão"350. Aliás, por essa razão, Agamben entende que Schmitt se encontra entre os autores que “... criticam sem restrição a pretensão de se regular por lei o que, por definição, não pode ser normatizado"351. Explica-se: se por um lado Agamben parece realmente concordar com alguns elementos da teoria da exceção schmittiana ${ }^{352}$, por outro lado, queremos crer que Agamben propõe, certamente na linha adotada por Benjamin, uma nova questão: o que ocorre quando a exceção se torna a regra ${ }^{353}$ ?

“... O que ocorreu e ainda está ocorrendo sob nossos olhos é que o espaço 'juridicamente vazio' do estado de exceção (em que a lei figura - ou seja, etimologicamente, na ficção - da sua dissolução, e no qual podia portanto acontecer tudo aquilo que o soberano julgava de fato necessário) irrompeu de seus confins espaço-temporais e, esparramando-se para fora deles, tende agora por toda parte a coincidir com o ordenamento normal, no qual tudo se torna assim novamente possível." 354

É justamente ao afirmar a normalização da exceção que Agamben problematiza a primazia da exceção proposta por Schmitt que, para WILLIAM RASCH, poderia parecer até

\footnotetext{
${ }^{349}$ AGAMBEN, Giorgio. Estado de exceção. Tradução de Iraci D. Poleti. São Paulo: Boitempo, 2004, p. 78.

${ }^{350}$ AGAMBEN, Giorgio. Homo sacer: o poder soberano e a vida nua I. Tradução de Henrique Burigo. Belo Horizonte: Editora UFMG, 2002, p. 16.

${ }^{351}$ AGAMBEN, Giorgio. Estado de exceção. Tradução de Iraci D. Poleti. São Paulo: Boitempo, 2004, p. 22.

${ }^{352} \mathrm{O}$ maior deles, em nosso entendimento, é o fato de que ambos Schmitt e Agamben pregam o fim do Estado, muito embora sob premissas e objetivos distintos.

${ }^{353}$ Isso fica evidente quando Agamben declara que o processo que Schmitt descreveu minuciosamente "e que nós estamos ainda hoje vivendo...". In: Homo sacer: o poder soberano e a vida nua I. Tradução de Henrique Burigo. Belo Horizonte: Editora UFMG, 2002, p. 44.

${ }^{354}$ AGAMBEN, Giorgio. Homo sacer: o poder soberano e a vida nua I. Tradução de Henrique Burigo. Belo Horizonte: Editora UFMG, 2002, p. 44.
} 
mesmo anacrônica - mas não o é -, porquanto a decisão já teria sido tomada ${ }^{355}$. Assim, o que está em jogo no debate Benjamin-Schmitt é o aparato jurídico fundado na exceção entendida como um espaço anômico em que, sugere Agamben, a relação entre lei e violência encontra seu ápice. O que é mais significante no trabalho benjaminiano, portanto, não é somente a assertiva de que a exceção se tornou a regra, mas também a necessidade de evoluirmos para um verdadeiro estado de exceção:

“O que está em jogo no debate entre Benjamin e Schmitt sobre o estado de exceção pode, agora, ser definido mais claramente. A discussão se dá numa mesma zona de anomia que, de um lado, deve ser mantida a todo custo em relação com o direito e, de outro, deve ser também implacavelmente libertada. O que está em questão na zona de anomia é, pois, a relação entre violência e direito - em última análise, o estatuto da violência como código da ação humana. Ao gesto de Schmitt que, a cada vez, tenta reinscrever a violência no contexto jurídico, Benjamin responde procurando, a cada vez, assegurar a ela como violência pura - uma existência fora do direito.”356

Se para Schmitt a decisão é o elo que une soberania e estado de exceção, “... Benjamin, de modo irônico, separa o poder soberano de seu exercício e mostra que o soberano barroco está, constitutivamente, na impossibilidade de decidir ${ }^{, 357}$. Para ARNE DE BOEVER, "Thus Schmitt's sovereignty confirms the dialetic between violence and the law; Benjamin's divine violence breaks $i t{ }^{\prime 358}$. BRUNO GULLI elucida a distinção entre Schmitt e Benjamin, ao tratar da violência divina em relação à violência soberana:

“... However, the fundamental difference between Schmitt and Benjamin lies in the fact that the latter sees in the institution of the police the degeneration of this form of violence: not indeed the distinction between lawmaking and lawpreserving (i.e., the violence that poses the law and that which preserves it), but their blurring and identification in the suspension or deposition of the law

\footnotetext{
${ }^{355}$ Para esse pensador, “... the decision has already been made, and that decision dictates that there will be no more decisions, that decisons will be replaced by universally valid, because rationally achieved, norms. Under the law, there will be no exception, just rule... But Schmitt's definition, though unpopular, is not all that anachronistic". RASCH, William. Op. cit., p. 95.

${ }^{356}$ AGAMBEN, Giorgio. Estado de exceção. Tradução de Iraci D. Poleti. São Paulo: Boitempo, 2004, p. 92. ${ }^{357}$ AGAMBEN, Giorgio. Estado de exceção. Tradução de Iraci D. Poleti. São Paulo: Boitempo, 2004, p. 87. ${ }^{358}$ BOEVER, Arne de. Op. cit., p. 83.
} 
brings to the fore the paradox of an exceptional situation which is no longer exceptional. For Benjamin, the revolutionary task is to oppose, to this form of degeneration, an 'effective state of exception', in which the polarization between sovereign power and naked life is reduced and taken away,., 359

Para Gilberto Bercovici, o estado de exceção de Schmitt defende a ordem contra a catástrofe, enquanto o “... estado de exceção de Walter Benjamin enxerga na ordem a catástrofe contínua da dominação" ${ }^{\text {"360 }}$. Por essas mesmas razões, WILLIAM RASCH conclui que: "Thus, this is the great distinction that organizes the work of Schmitt, Benjamin and Agamben - not totalitarianism versus democratic rule of law, but the metaphysics of the West, which is characterized by the ontology of sovereignty, versus a post-metaphysical ontology of the political yet to be realized ${ }^{3361}$.

É nesse cenário que Agamben volta sua simpatia para a tese de Benjamin - há quem entenda que ele se apropria da tese benjaminiana ${ }^{362}$-, que se torna central em sua obra. Como veremos, para Agamben não é o soberano que decide acerca do estado de exceção, como sustenta Schmitt, mas sim o seu inverso: a violência que põe o estado de exceção também decide a soberania e, ainda, quem é o soberano, de modo que a crítica de Benjamin se torna fundamental, especialmente em sua ênfase quanto à violência representada pela polícia, na qual a separação do criador da lei e do preservador da lei é suspensa.

Em última instancia, Agamben defenderá que, enquanto Schmitt traz - ou tenta trazer - o poder da exceção à ordem jurídica, Benjamin desativa esse poder numa nova política além da lei e além do Estado. Em outras palavras, enquanto Schmitt se coloca dentro do político-jurídico conforme definido pela exceção soberana, ambos Benjamin e Agamben, como veremos mais claramente abaixo, imaginam a possibilidade de uma política que exceda o político-jurídico ou, como qualificou Zizek, uma biopolítica póspolítica.

\footnotetext{
${ }^{359}$ GULLI, Bruno. Op. cit., p. 238.

${ }^{360}$ BERCOVICI, Gilberto. Soberania e constituição: para uma crítica do constitucionalismo. São Paulo: Quartier Latin, 2008, p. 343.

${ }^{361}$ RASCH, William. Op. cit., p. 99

362 “... Agamben appropriates Walter Benjamin's apothegm that the exception has become the rule as a means of responding to the Schmittian conception of sovereignty and law as founded on the exception". MILLS, Catherine. The philosophy of Agamben. McGill-Queen's University Press, 2008, p. 81.
} 


\subsection{O ESTADO DE EXCEÇÃo EM AGAMBEN}

\subsubsection{A exclusão inclusiva}

Como descrito no capítulo anterior, partindo da paradoxal concepção de soberania em Schmitt, Agamben terá o seu próprio mecanismo para tratar da relação entre factum e ius. Com efeito, muito embora JESSICA WhYTE entenda que Schmitt e Agamben corroborem a mesma definição de soberania enquanto figura limítrofe ${ }^{363} \mathrm{e}$, ainda, muito embora ANDREW NORRIS entenda que “Agamben's acceptance of Schmitt's decisionism makes it impossible for his analysis to have any general validity" ${ }^{364}$, parece-nos que a melhor leitura é no sentido de que a articulação entre estado de exceção e ordem jurídica proposta por Schmitt é, segundo Agamben, paradoxal, na medida em que “... o que deve ser inscrito no direito é algo essencialmente exterior a ele, isto é, nada menos que a suspensão da própria ordem jurídica (donde a formulação aporética: 'Em sentido jurídico... ainda existe uma ordem, mesmo não sendo uma ordem jurídica'),"365.

"Se o soberano é, de fato, aquele no qual o ordenamento jurídico reconhece o poder de proclamar o estado de exceção e de suspender, deste modo, a validade do ordenamento, então 'ele permanece fora do ordenamento jurídico e, todavia, pertence a este, porque cabe a ele decidir se a constituição in toto possa ser suspensa' (Schmitt, 1922, p.34). A especificação 'ao mesmo tempo' não é trivial: o soberano, tendo o poder legal de suspender a validade da lei, colocase legalmente fora da lei. Isto significa que o paradoxo pode ser formulado também deste modo: 'a lei está fora dela mesma', ou então: 'eu, o soberano, que estou fora da lei, declaro que não há um fora da lei." ${ }^{\text {366 }}$

\footnotetext{
363 "Like Schmitt, Agamben understands sovereignty as a 'borderline concept"”. WHYTE, Jessica. Its silent working was a delusion. In: The work of Giorgio Agamben: law, literature, life. Edinburg University Press, 2008 , p. 69.

364 NORRIS, Andrew. The exemplary exception: philosophical and political decisions in Giorgio Agamben's Homo Sacer. In: Politics, metaphysics and death: essays on Giorgio Agamben. Durham and London: Duke University Press: 2005, p. 278.

${ }^{365}$ AGAMBEN, Giorgio. Estado de exceção. Tradução de Iraci D. Poleti. São Paulo: Boitempo, 2004, p. 54.

${ }^{366}$ AGAMBEN, Giorgio. Homo sacer: o poder soberano e a vida nua I. Tradução de Henrique Burigo. Belo Horizonte: Editora UFMG, 2002, p. 23.
} 
Quer dizer, no paradoxo schmittiano o soberano se coloca legalmente fora da lei: ele está, ao mesmo tempo, dentro e fora do direito, ou como o próprio Agamben revela no texto The Messiah and the sovereign: the problem of law in Walter Benjamin, o paradoxo implícito nessa definição - que pode ser referido como o paradoxo da soberania - consiste no fato de que o soberano, tendo o poder legítimo de suspender a lei, encontra-se ao mesmo tempo dentro e fora da ordem jurídica ${ }^{367}$. TERCIO SAMPAIO FERRAZ JR. igualmente detecta esse paradoxo schmittiano, no qual "a soberania não é um fato (força), não é também uma situação jurídica"368, muito embora encontre uma saída - uma via possível no modelo comunicacional de Niklas Luhmann ${ }^{369}$.

Consciente do paradoxo da soberania contido na noção decisionista schmittiana de exceção $^{370}$ e motivado a confrontá-la à violência benjaminiana, Agamben traz à tona, no quinto capítulo de Il tempo che resta, denominado Estado de exceção, assim como no livro que leva o mesmo título e, ainda, em Homo sacer - e, a bem da verdade, na grande parte de sua obra -, uma relação mais íntima entre lei e violência, na qual a soberania não é tratada como externa à ordem jurídica. De fato, Agamben deixa claro que designar a exceção como algo fora da lei não é estritamente correto ("a soberania não é... uma potência externa ao direito $\left.(S c h m i t t){ }^{, 371}\right)$, uma vez que não está dentro, nem fora (não/nem), ainda que simultaneamente, mas num estado indeterminado entre eles. Na visão de CATHERINE MiLls, designar a exceção como simplesmente externa à lei não está correto no pensamento agambeniano ${ }^{372}$ e, nesse sentido, explica que "But contrary to Schmitt, for Agamben the exception is not only an irruption in the torpidity of regulatory mechanisms, but instead, indicates the 'inner nature' of law itself, or at least an irremediable condition of its application". Para MALCOLM BulL, a divergência entre Agamben e Schmitt pode ser deduzida das contraposições expressas em Homo sacer e Stato di eccezione:

${ }^{367}$ Cf. Giorgio AGAMBEN. In: On Potentiality. In: HAMACHER, Werner; WELBERY, David (ed.). Potentialities. Stanford: Stanford University Press, 1999, p. 161.

${ }^{368}$ Cf. Tercio Sampaio FERRAZ Jr. Op. cit., Nota à 3 ed. e p.52.

${ }^{369}$ Cf. Tercio Sampaio FERRAZ Jr. Op. cit., p. 32.

370 "In answering this question, I found there to be nothing more helpful that the epistemological paradigms at the centre of the work of a jurist who developed his conception of law and the sovereign state according to an explicitly anti-messianic condition... According to Schmitt, whom you will have already identified without my naming him, the paradigm that defines the proper function and structure of the law is not the norm, but the exceptio". AGAMBEN, Giorgio. The time that remains: a commentary on the letter to the Romans. Tradução Patricia Dailey. Stanford: Stanford University Press, 2005, p. 104

${ }^{371}$ AGAMBEN, Giorgio. Homo sacer: o poder soberano e a vida nua I. Tradução de Henrique Burigo. Belo Horizonte: Editora UFMG, 2002, p. 35.

${ }^{372}$ Cf. Catherine MILLS. In: Biopolitics, liberal eugenics, and nihilism. In: CALARCO, Matthew; DECAROLI, Steven (ed.). Giorgio Agamben: sovereignty and life. Stanford, California: Stanford University Press, 2007, p. 190-191. 
"However, whereas in Homo Sacer Agamben follows Schmitt in arguing that the exception remains accessible to jurisprudence 'because the norm as well as the decision remain within the framework of the juristic', in this book he argues that the state of exception is not a state of law at all, but a legal void within the juridical order." 373

Inclinamo-nos, assim, a entender que Agamben, muito longe de aceitar o paradoxo schmittiano, pretende opor-se a ele, linha também adotada por LELAND DE LA DURANTAYE ${ }^{374}$. Agamben coloca de lado a discussão dentro/fora do estado de exceção em relação ao ordenamento jurídico, porquanto essa oposição “... parece ser insuficiente para dar conta do fenômeno que deveria explicar ${ }^{\text {"375 }}$, e indica a relação resultante como uma de esclusione inclusiva - "a seizing of the outside»,376, que serve para incluir o que é excluído , por meio da qual o que é excluído do domínio da lei é também incluído em virtude de sua exclusão. A significação da exceção agambeniana em sua relação de exclusão inclusiva é trazida nas primeiras páginas de Homo sacer:

“A exceção é uma espécie de exclusão. Ela é um caso singular, que é excluído da norma geral. Mas o que caracteriza propriamente a exceção é que aquilo que é excluído não está, por causa disto, absolutamente fora da relação com a norma; ao contrário, esta se mantém em relação com aquela na forma de sua suspensão. A norma se aplica à exceção desaplicando-se, retirando-se desta... Neste sentido, a exceção é verdadeiramente, segundo o étimo, capturada (excapere) e não simplesmente excluída."377

De acordo com VladimiR SAFATLE, “... a exceção indica que o fundamento da Lei é aquilo que pode manifestar-se de maneira negativa, transgredindo a própria Lei, sem

\footnotetext{
${ }^{373}$ BULL, Malcolm. States don't really mind their citizens dying (provided they don't all do it at once): they just don't like anyone else to kill them. Disponível em http://www.generationonline.org/p/fpagamben2.htm. Acessado em 5.8.2009.

${ }^{374}$ In: Giorgio Agamben: a critical introduction. Stanford: Stanford University Press, 2009, p. 365.

375 AGAMBEN, Giorgio. Estado de exceção. Tradução de Iraci D. Poleti. São Paulo: Boitempo, 2004, p. 39.

${ }^{376}$ AGAMBEN, Giorgio. The time that remains: a commentary on the letter to the Romans. Tradução Patricia Dailey. Stanford: Stanford University Press, 2005, p. 105.

377 AGAMBEN, Giorgio. Homo sacer: o poder soberano e a vida nua I. Tradução de Henrique Burigo. Belo Horizonte: Editora UFMG, 2002, p. 25.
} 
fazer com que ela deixe de estar em vigor ${ }^{, 378}$. O direito não possui outra vida além daquela que consegue capturar dentro de si por meio da exclusão inclusiva da exceptio: ele se nutre dela e, sem ela, é letra morta. A relação da lei com aquilo que é dela excluído não é simplesmente, destarte, uma relação de não-aplicação, como crê Schmitt. Ao contrário, Agamben sugere que ela é mais fielmente descrita na caracterização do banimento $^{379}$ de Jean-Luc Nancy, no qual a lei se aplica a seu objeto somente em sua própria paralisação. A questão do lócus do estado de exceção é, portanto, de extrema relevância, uma vez que o estado de exceção sempre se apresenta como ocupando uma zona de indiferença entre fato e norma jurídica, um movimento de suspensão, um non/né com relação ao fato e à norma jurídica, até mesmo porque, como entende BRUNO GULLI, "In truth, it is not the sovereign who decides of the state of exception (as Schmitt holds), but the other way around: the violence that posits the state of exception also decides on sovereignty, on who the sovereign is... $" 380$. Para Agamben, que uma vez mais reflete a estrutura do não/nem:

" $\mathrm{Na}$ verdade, o estado de exceção não é nem exterior nem interior ao ordenamento jurídico e o problema de sua definição diz respeito a um patamar, ou a uma zona de indiferença em que dentro e fora não se excluem mas se indeterminam. A suspensão da norma não significa sua abolição e a zona de anomia por ela instaurada não é (ou, pelo menos, não pretende ser) destituída de relação com a ordem jurídica." 381

Assim, aquilo que está fora é igualmente incluído não simplesmente por meio de uma interdição ou um internamento - dentro/fora -, mas suspendendo a validade do ordenamento, deixando, portanto, que ele se retire da exceção, abandone-a ${ }^{382}$. Ato contínuo, Agamben pôde finalmente qualificar a relação de exceção:

\footnotetext{
${ }^{378}$ SAFATLE, Vladimir. Materialismo, imanência e política: sobre a teoria da ação de Giorgio Agamben. In: SEDLMAYER, Sabrina; GUIMARÃES, César; OTTE, Georg. O comum e a experiência da linguagem. Belo Horizonte: Editora UFMG, 2007, p. 102.

${ }^{379}$ Que será examinado em capítulo específico.

${ }^{380}$ GULLI, Bruno. The ontology and politics of exception: reflections on the work of Giorgio Agamben. In: In: CALARCO, Matthew; DECAROLI, Steven (ed.). Giorgio Agamben: sovereignty and life. Stanford, California: Stanford University Press, 2007. p. 235.

${ }_{381}^{381}$ AGAMBEN, Giorgio. Estado de exceção. Tradução de Iraci D. Poleti. São Paulo: Boitempo, 2004, p. 39.

${ }^{382} \mathrm{Cf}$. Giorgio AGAMBEN. In: Homo sacer: o poder soberano e a vida nua I. Tradução de Henrique Burigo. Belo Horizonte: Editora UFMG, 2002, p. 26.
} 
"Não é a exceção que se subtrai à regra, mas a regra que, suspendendo-se, dá lugar à exceção e somente deste modo se constitui como regra, mantendo-se em relação com aquela. O particular 'vigor' da lei consiste nessa capacidade de manter-se em relação com uma exterioridade. Chamemos relação de exceção a esta forma extrema da relação que inclui alguma coisa unicamente através de sua exclusão."383

Como Agamben deixa claro no capítulo que versa sobre o instituto romano do iustitium, um arquétipo ou "paradigma genealógico",384 do estado de exceção que literalmente significa uma suspensão da lei - não somente uma suspensão da administração da justiça, mas da própria lei -, o local do estado de exceção, nessa suspensão, é realmente um absoluto não-lugar, um ponto de indiferença. Agamben confere um capítulo inteiro de Estado de exceção para tratar das origens históricas - e evoluções semânticas - do iustitium enquanto estado de exceção, é dizer, como suspensão do direito para se enfrentar um tumultus. Aclara-se:

“Quando tinha notícia de alguma situação que punha em perigo a República, o Senado emitia um senatus consultum ultimum por meio do qual pedia aos cônsules (ou a seus substitutos em Roma, interrex ou pró-cônsules) e, em alguns casos, também aos pretores e aos tribunos da plebe e, no limite, a cada cidadão, que tomassem qualquer medida considerada necessária para a salvação do Estado (rem publicam defendant, operamque dent ne quid respublica detrimenti capiat). Esse senatus-consulto tinha por base um decreto que declarava o tumultus (isto é, a situação de emergência em Roma, provocada por uma guerra externa, uma insurreição ou uma guerra civil) e dava lugar, habitualmente, à proclamação de um iustitium.",385

Isto é, no caso de um tumultus, que poderia surgir da mera especulação de uma guerra externa - o que pode ser hoje comparado aos rumores econômicos -, exemplificativamente, o direito era suspenso para sua própria existência por meio de uma deliberação do Senado, o senatus-consultos, que, de acordo com THOMAS MARKY, é uma

${ }^{383}$ AGAMBEN, Giorgio. Homo sacer: o poder soberano e a vida nua I. Tradução de Henrique Burigo. Belo Horizonte: Editora UFMG, 2002, p. 26.

${ }^{384}$ AGAMBEN, Giorgio. Estado de exceção. Tradução de Iraci D. Poleti. São Paulo: Boitempo, 2004, p. 75.

${ }^{385}$ AGAMBEN, Giorgio. Estado de exceção. Tradução de Iraci D. Poleti. São Paulo: Boitempo, 2004, p. 67. 
fonte do direito romano ${ }^{386}$. Uma interrupção do direito, com caráter de ultimus à luz da iminente crise, justamente para salvá-lo: assim como o sol para no solstitium, o direito para no iustitium. Para salvaguarda do Estado romano, os cônsules são reduzidos à condição de simples particulares - estão in privato abditi -, enquanto cada particular age como se estivesse revestido de um imperium, de um "imperium flutuante e anômalo" ${ }^{387}$. Não por outra razão, nesse espaço anômico, vazio de direito, não poderia haver cumprimento ou transgressão da lei, assim como não há distinção entre público e privado, porquanto cônsul, magistrado e cidadão estavam livres para agir como achar melhor e, em último caso, não $\operatorname{agir}^{388}$ :

"If, in the state of exception, the law is in force in the form of its suspension, being applied in disapplying itself, then the law thus includes, so to speak, that which is rejected from itself... If this is true, then in the state of exception it becomes impossible to distinguish between observance [osservanza] and transgression of the law. When the law is in force only in the form of its suspension, no matter what mode of behavior appears to be in line with the law in a normal situation - like walking peacefully down the street - this behavior might also imply a transgression - as, for example, in the case of the curfew. Vice versa, the transgression may even be conceived of as a carrying out the law." 389

Em outras palavras, não há no estado de exceção possibilidade de distinção entre execução e transgressão da lei, pois se a norma pode ser suspensa sem, no entanto, deixar de estar em vigor, é porque seu regime de aplicabilidade pode englobar sua própria suspensão: sua significação não reconhece um campo seguro de indicações. Outro exemplo tirado da historicidade romana é o próprio fundamento do poder do Senado de suspender o direito por meio do senatus consultum ultimum à luz da contraposição entre auctoritas e potestas. Partindo de Schmitt, que teria tentado ${ }^{390}$, em Der hüter der Verfassung, “definir o

\footnotetext{
${ }^{386}$ MARKY, Thomas. Curso elementar de direito romano. 8 ed. São Paulo: Saraiva, 1995, p. 18.

${ }^{387}$ Cf. Giorgio AGAMBEN. In: Estado de exceção. Tradução de Iraci D. Poleti. São Paulo: Boitempo, 2004, p. 70 e 121.

${ }^{388}$ Cf. Giorgio AGAMBEN. In: Estado de exceção. Tradução de Iraci D. Poleti. São Paulo: Boitempo, 2004, p. 78 .

389 AGAMBEN, Giorgio. The time that remains: a commentary on the letter to the Romans. Tradução Patricia Dailey. Stanford: Stanford University Press, 2005, p. 105.

${ }^{390}$ Como de fato tentou, em nosso entendimento: "As divergências de opinião e diferenças entre os titulares de direitos políticos de decisão... são eliminadas ou por meio de um poder político mais forte situado acima
} 
poder neutro do presidente do Reich no estado de exceção contrapondo, dialeticamente, auctoritas $e$ potestas" 391 , e concordando com ele na assunção de que o sintagma que define a função do Senado é a auctoritas - nem imperium, nem potestas -, Agamben, em termos gerais, reflete que o sistema jurídico do Ocidente apresenta-se como uma estrutura formada por dois elementos heterogêneos, mas coordenados: um elemento normativo e jurídico, que Agamben nomeia potestas, e um elemento anômico e metajurídico, que Agamben designa auctoritas.

No direito público romano, a auctoritas assinala a prerrogativa por excelência do Senado, ou seja, representa moralmente a autoridade dos patriarcas (auctoritas patrum), de acordo com JOSÉ REINALDO DE LIMA LOPES ${ }^{392}$. O senador não é um magistrado, mas uma figura que intervém para ratificar e tornar plenamente válidas as decisões dos comícios populares. Isso porque o Senado não teria uma ação própria e poderia agir somente em ligação com o magistrado ou para homologar decisões populares. Trata-se de "um poder que confere legitimidade,393.

Já a potestas pode ser entendida como o poder jurídico de um magistrado, um poder ligado à função ou cargo público e não à pessoa em si. $\mathrm{Na}$ visão agambeniana, para compreendermos fenômenos modernos como o Duce fascista e o Führer nazista, precisamos entender que ambos não representam magistraturas ou cargos públicos constitucionalmente definidos, ainda que Hitler e Mussolini estivessem investidos no cargo de chanceler do Reich e de chefe de governo, respectivamente, assim como o próprio Augusto romano. As qualidades de todos eles estão ligadas diretamente à pessoa física e pertencem à tradição biopolítica da auctoritas e não à tradição jurídica da potestas, é dizer, a auctoritas seria ligada ao poder carismático weberiano, como poder original e pessoal de

das opiniões divergentes, isto é, por intermédio de um terceiro superior - mas isso não seria, então, o guardião da Constituição, e, sim, o senhor soberano do Estado, ou então são conciliadas ou resolvidas por meio de um órgão não em relação de subordinação, mas de coordenação, isto é, por meio de um terceiro neutro - este é o sentido de um poder neutro, de um pouvoir neutre et intermédiaire, localizado não acima, e, sim, ao lado dos outros poderes constitucionais, mas dotado de poderes e possibilidades de ação singulares". In: O guardião da Constituição. Traduçao de Geraldo de Carvalho. Belo Horizonte: Del Rey, 2007, p. 193.

391 AGAMBEN, Giorgio. Estado de exceção. Tradução de Iraci D. Poleti. São Paulo: Boitempo, 2004, p. 116.

${ }^{392}$ LOPES, José Reinaldo de Lima. O direito da história: lições introdutórias. 2. ed. São Paulo: Max Limonad, 2002, p. 57.

${ }^{393}$ Cf. Giorgio AGAMBEN. In: Estado de exceção. Tradução de Iraci D. Poleti. São Paulo: Boitempo, 2004, p. $120-121$. 
um chefe (Führertum $)^{394}$. Não por outra razão, ELLEN KENNEDY revela que a teoria schmittiana tem por base a observação weberiana ${ }^{395}$ de que até mesmo os governos que trabalham da maneira mais perfeita possível em relação à legalidade precisam de um certo carisma $^{396}$. Mutatis mutandis, no País, JosÉ AfONSO DA SILVA revela que “... um dos arraigados elementos da cultura política brasileira consiste na primazia do Poder Executivo... Larga camada do povo mais carente acalenta a cultura paternalista que vem do coronelismo" 397 .

Assim, para que algo possa existir no direito, é necessário aquele que é munido de auctoritas, bem como aquele que toma a iniciativa do ato, ou seja, que detém a coisa in potestate. Na teoria da exceção agambeniana, a auctoritas age como “... uma força que suspende a potestas onde ela agia e a reativa onde ela não estava mais em vigor. É um poder que suspende ou reativa o direito, mas não tem vigência formal como direito ${ }^{398}$.

Nesse cenário, a norma pode ser aplicada ao caso normal e pode ser suspensa sem anular inteiramente a ordem jurídica porque, sob a forma da auctoritas ou da decisão soberana, ela se refere imediatamente à vida e dela deriva. Se a potestas necessita de um elemento anômico para poder ser aplicada, a auctoritas só pode se afirmar numa relação de validação ou suspensão da potestas. O estado de exceção é justamente o dispositivo que deve "articular e manter juntos" $" 399$ os elementos desse esquematismo binário, inaugurando um patamar de indecidibilidade entre eles.

Por conseguinte, para que uma norma seja aplicada é necessário suspender a sua aplicação, quer dizer, produzir uma exceção. "A situação, que vem a ser criada na exceção, possui, portanto, este particular, o de não poder ser definida nem como um

\footnotetext{
${ }^{394}$ Cf. Giorgio AGAMBEN. In: Estado de exceção. Tradução de Iraci D. Poleti. São Paulo: Boitempo, 2004, p. 127-129.

${ }^{395}$ Schmitt participou de seminários proferidos por Weber em Munique em 1919 e 1920.

${ }^{396}$ Cf. Ellen KENNEDY. In: Constitutional failure: Carl Schmitt in Weimar. Durham and London: Duke University Press, 2004, p. 78.

${ }^{397}$ SILVA, José Afonso da. A governabilidade num Estado Democrático de Direito. In: VALADÉS, Diego (Ed.). Gobernabilidad y constitucionalismo en América Latina. México: Universidad Nacional Autónoma de México, 2005, p. 16.

${ }^{398}$ AGAMBEN, Giorgio. Estado de exceção. Tradução de Iraci D. Poleti. São Paulo: Boitempo, 2004, p. 121.

${ }^{399}$ AGAMBEN, Giorgio. Estado de exceção. Tradução de Iraci D. Poleti. São Paulo: Boitempo, 2004, p. 130.
} 
situação de fato, nem como uma situação de direito, mas institui entre estas um paradoxal limiar de indiferença" ${ }^{\sharp 00}$.

Percebe-se, por conseguinte, a existência de uma lacuna, muito embora não em termos de um vazio na letra da lei que poderia ser remediado pela interpretação da própria ordem jurídica $^{401}$. Ao contrário, a lacuna que indetermina a lei reside na relação entre lei e vida, entre a norma e o mundo, ou nomos e phýsis. A exceção, portanto, não é um fato porque é criada apenas pela suspensão da norma jurídica, mas, pela mesma razão, não é igualmente um caso jurídico, ainda que abra possibilidade de vigência da lei. Não é uma quaestio iuris, nem uma quaestio facti (não/nem). Agamben conclui que, longe de ser uma resposta a uma lacuna normativa - ou seja, interna à lei -, o estado de exceção aparece como o preenchimento de uma lacuna fictícia na ordem para fins de salvaguardar a existência da norma e sua aplicação à situação normal.

A lacuna não é dentro da lei, mas na relação desta com a realidade - o outrora abismo entre ser e dever-ser. Isso indica que a ordem jurídica contém uma fratura que só pode ser remediada por meio da criação de um estado de exceção no qual a lei é suspensa, mas, ainda assim, permanece em vigor. "Com toda evidência, de fato, a violência que é exercida no estado de exceção não conserva nem simplesmente põe o direito, mas o conserva suspendendo-o e o põe excetuando-se ${ }^{, 402}$ (... ma lo conserva sospendendolo e lo pone eccependosi da esso).

E é dentro do espaço dessa lacuna que a decisão soberana ganha particular significância e indica a posição limítrofe do soberano na relação entre vida e lei. " $A$ decisão soberana sobre a exceção é, neste sentido, a estrutura político-jurídica originária, a partir da qual somente aquilo que é incluído no ordenamento e aquilo que é excluído dele adquirem seu sentido" "403. A soberania, destarte, não decide o lícito ou o ilícito

\footnotetext{
${ }^{400}$ AGAMBEN, Giorgio. Homo sacer: o poder soberano e a vida nua I. Tradução de Henrique Burigo. Belo Horizonte: Editora UFMG, 2002, p. 26.

${ }^{401} \mathrm{Na}$ hipótese brasileira, por meio da analogia, costumes e princípios gerais do direito, a mero título de exemplo.

${ }^{402}$ AGAMBEN, Giorgio. Homo sacer: o poder soberano e a vida nua I. Tradução de Henrique Burigo. Belo Horizonte: Editora UFMG, 2002, p. 72.

${ }^{403}$ AGAMBEN, Giorgio. Homo sacer: o poder soberano e a vida nua I. Tradução de Henrique Burigo. Belo Horizonte: Editora UFMG, 2002, 27.
} 
(legal/ilegal), mas a inclusão originária do vivente dentro de seu campo de ordem. A exceção marca o local em que o legal entra em relação com o não-legal ${ }^{404}$.

E, ao estabelecer uma fronteira - indiscernível, mas ainda assim uma fronteira entre legal e não-legal, a exceção efetivamente produz os dois. Se a questão da soberania reduzia-se a identificar quem, no interior do ordenamento, fosse investido de certos poderes, sem que o próprio limiar do ordenamento fosse jamais posto em questão, hoje, as estruturas estatais entraram em processo de dissolução e a emergência, como diz Benjamin, tornou-se a regra, propondo-se um nova estrutura originaria da estatalidade. Propõe-se uma revisão sem reservas.

Somente na exceção a vida é verdadeiramente trazida à esfera da lei, ou seja, a decisão do soberano estabelece uma passagem da lei à vida e é, portanto, o limite pelo qual a vida é tomada dentro da lei: "O soberano não decide entre lícito e ilícito, mas a implicação originária do ser vivente na esfera do direito..." ${ }^{~} 405$ Há, por conseguinte, uma figura-limite da vida, uma fronteira na qual vida não está dentro, nem está fora, da ordem jurídica, e é nesse local que se encontra a soberania. Assim, a tese agambeniana sugere que é por meio da exceção que soberania e vida são levados à conjunção. Com efeito, o soberano determina quando a lei é aplicável e a quê ela é aplicável, criando, desse modo, as condições indispensáveis - ou melhor, a situação necessária - para a lei operar (muito embora exista aqui mais uma semelhança com Schmitt, a diferença reside no fato de que o estado de exceção não está fora da ordem jurídica, mas é derivado da própria suspensão da lei):

"Na sua forma arquetípica, o estado de exceção é, portanto, o princípio de localização jurídica, posto que somente ele abre o espaço em que a fixação de um certo ordenamento e de um determinado território se torna pela primeira vez possível."406

\footnotetext{
${ }^{404}$ Cf. Steven DECAROLI: "In fact, the political distinction between inside and outside, inclusion and exclusion, estructures the basic logic of sovereignty itself, insofar as sovereignty maintains a boundary not between the legal and the illegal, both of which participate fully in the logic of legality, but between the legal and the non-legal, that is, between the lawful and the outlaw, between the citizen and the exile". Op. cit., p. 51

${ }^{405}$ AGAMBEN, Giorgio. Homo sacer: o poder soberano e a vida nua I. Tradução de Henrique Burigo. Belo Horizonte: Editora UFMG, 2002, p. 33.

${ }^{406}$ AGAMBEN, Giorgio. Homo sacer: o poder soberano e a vida nua I. Tradução de Henrique Burigo. Belo Horizonte: Editora UFMG, 2002, p. 27.
} 
Isso significa que o estado de exceção opera tanto como condição da aplicação da lei, como efeito da decisão soberana, de maneira que a exceção não está simplesmente fora do alcance da lei, mas, na verdade, é criado por meio da suspensão da lei. Assim sendo, “... a afirmação segundo a qual 'a regra vive somente da exceção' deve ser tomada, portanto, ao pé da letra" ${ }^{, 407}$.

Em outras palavras, o estado de exceção é aquele em que o que é excluído do alcance da lei continua a manter a relação com a ordem legal precisamente por meio da suspensão dessa ordem: “... what is excluded from the norm does not simply have no bearing on the law; on the contrary, the law maintains itself in relation to the exception in the form of its own self-suspension "408.

"Para se referir a algo, uma norma deve, de fato, pressupor aquilo que está fora da relação (o irrelato) e, não obstante, estabelecer desde modo uma relação com ele. A relação de exceção exprime assim simplesmente a estrutura originária da relação jurídica."409

Nesse sentido, Agamben argumenta que a estrutura da potencialidade corresponde exatamente àquela da operação da soberania, na qual o soberano decide ao quê a lei se aplica, porquanto "... an act is sovereign when it realizes itself by simply taking away its own potentiality not to be, letting itself be, giving itself to itself ${ }^{410}$.

A força particular do soberano em relação à exceção é que ele se mantém indefinidamente em sua própria potencialidade, porquanto “... à estrutura da potência, que se mantém em relação com o ato precisamente através de seu poder não ser, corresponde aquela do bando soberano, que aplica-se à exceção desaplicando-se" ${ }^{\text {411. }}$

\footnotetext{
${ }^{407}$ AGAMBEN, Giorgio. Homo sacer: o poder soberano e a vida nua I. Tradução de Henrique Burigo. Belo Horizonte: Editora UFMG, 2002, p. 34.

${ }^{408}$ AGAMBEN, Giorgio. The time that remains: a commentary on the letter to the Romans. Tradução Patricia Dailey. Stanford: Stanford University Press, 2005, p. 104.

${ }^{409}$ AGAMBEN, Giorgio. Homo sacer: o poder soberano e a vida nua I. Tradução de Henrique Burigo. Belo Horizonte: Editora UFMG, 2002, p. 27.

${ }^{410}$ MILLS, Catherine. The philosophy of Agamben. McGill-Queen's University Press, 2008, p. 75.

${ }^{411}$ AGAMBEN, Giorgio. Homo sacer: o poder soberano e a vida nua I. Tradução de Henrique Burigo. Belo Horizonte: Editora UFMG, 2002, p. 54.
} 
“A potência (no seu dúplice aspecto de potência de e potência de não) é o modo através do qual o ser se funda soberanamente, ou seja, sem nada que o preceda e determine (superiorem non recognoscens), senão o próprio poder não ser. E soberano é aquele ato que se realiza simplesmente retirando a própria potência de não ser, deixando-se ser, doando-se a si." ${ }^{, 412}$

Disso decorre que o problema da soberania retorna a filosofia política à ontologia, que necessita uma reconstrução da relação metafísica entre potencialidade e atualidade. " $A$ soberania é sempre dúplice, porque o ser se auto-suspende mantendo-se, como potência, em relação de bando (ou abandono) consigo, para realizar-se então como ato absoluto (que não pressupõe, digamos, nada mais do que a própria potência)" ${ }^{\text {"413 }}$. Aqui é preciso lembrarmos que, para Agamben, a potencialidade deve ser vista como uma forma de atualidade e vice-versa, uma vez que o ato é a realização da impotência e, assim, ato e potência se tornam indistintos: o soberano é justamente essa zona de indistinção e, no ato soberano, a potencialidade se suspende numa relação de banimento para se realizar.

O mesmo raciocínio é conferido à soberania enquanto fenômeno introduzido na figura da polícia, no sentido benjaminiano acima exposto, ou seja, não enquanto executor da lei, mas enquanto figura contígua do governo: para Agamben, as premissas de ordem pública e segurança sob as quais a polícia decide caso a caso definem a área de indistinção entre violência e direito que é exatamente simétrica à área da soberania - daí, aliás, o título do texto Polícia soberana, escrito por Agamben em 1991 ${ }^{414}$. Para JUdiTH ButLer, “... Governmentality is the condition of this new exercise of sovereignty in the sense that it first establishes a 'tactic', something of instrumental value, and not 'binding' by virtue of its status as law. In a sense, the self-annulment of law under the condition of a state of emergency revitalizes the anachronistic 'sovereign' as the newly invigorated subjects of managerial power". Isto é, o governo produz uma norma que não é lei, um colegiado que não é tribunal, um processo que não é processo: a lei é suspensa para aplicação de normas governamentais.

\footnotetext{
${ }^{412}$ AGAMBEN, Giorgio. Homo sacer: o poder soberano e a vida nua I. Tradução de Henrique Burigo. Belo Horizonte: Editora UFMG, 2002, p. 54.

${ }^{413}$ AGAMBEN, Giorgio. Homo sacer: o poder soberano e a vida nua I. Tradução de Henrique Burigo. Belo Horizonte: Editora UFMG, 2002, p. 54.

${ }^{414}$ Cf. Giorgio AGAMBEN. In: Means without end: notes on politics. Traducão Vincenzo Binetti e Cesare Casarino. Minneapólis: University of Minnesota Press, 2000, p. 104.
} 
Outrossim, como fronteira da vida e da lei, então, parece-nos que a soberania seria interna à biopolítica ${ }^{415}$, porquanto a estrutura da exceção agambeniana que baseia a lei é ela mesma o meio pelo qual vida é trazida à lei: a coincidência entre lei e vida. Nesse raciocínio, o aspecto normativo do direito pode ser impunemente eliminado e contestado por uma violência governamental que, ao ignorar no âmbito externo o direito internacional e produzir no âmbito interno um estado de exceção permanente, pretende, ainda assim, aplicar o direito. A criação voluntária de um estado de exceção efetivo - ainda que não declarado no sentido técnico-jurídico - tornou-se uma das práticas essenciais da operação político-jurídica contemporânea, inclusive dos países democráticos, como já elucidado acima. Sob o véu da "justiça, segurança emprego, moradia, saúde e educação... desenvolvimento e erradicação da miséria... sobretudo a ética nas relações do poder com a cidadania" ${ }^{416}$, que são os elementos da governabilidade dos países periféricos para PAULO BONAVIDES, há uma intervenção fictícia - Bonavides chega até mesmo a mencionar uma ditadura constitucional do presidencialismo no País à luz da adoção de uma forma de partido/governo único em que o Estado federal desfalece diante de um Executivo onde prepondera o arbítrio sobre a razão ${ }^{417}$-, mas contínua, por meio da polícia sem rosto. HARDT e NEGRI, enquanto divirjam numa série de considerações - mas compartilham com Agamben a busca por uma transformação, em que pesem os fundamentos diversos -, concordam que há um estado de exceção permanente reconhecidamente presente como núcleo do direito imperial, muito embora não se confunda com artes jurídicas da ditadura e do totalitarismo que em outras eras e com grande alarde foram exaustivamente descritos ${ }^{418}$, inclusive por Agamben na sua própria conceituação de estado de exceção:

“O poder jurídico de reinar sobre a exceção e a capacidade de usar a força policial são, portanto, duas coordenadas iniciais que definem o modelo imperial de autoridade... O que está por trás dessa intervenção não é um permanente estado de emergência e exceção, mas um permanente estado de emergência e exceção justificado pelo apelo a valores essenciais de justiça. Em outras palavras, o direito de polícia é legitimado por valores universais...

\footnotetext{
${ }^{415} \mathrm{Cf}$. Catherine MILLS. Biopolitics, liberal eugenics, and nihilism. In: Giorgio Agamben: sovereignty and life. Stanford, California: Stanford University Press, 2007. p. 192.

${ }^{416}$ BONAVIDES, Paulo. Governança e legitimidade (alguns aspectos da conjuntura brasileira). In: VALADÉS, Diego (Ed.). Gobernabilidad y constitucionalismo en América Latina. México: Universidad Nacional Autónoma de México, 2005, p. 31.

${ }^{417}$ Cf. Paulo BONAVIDES. Op. cit., p. 43 e 46.

${ }^{418}$ Cf. HARDT, Michel; NEGRI, Antonio. In: Império. Traduçao de Berilo Vargas, 8 ed. Rio de Janeiro: Record, 2006, p. 45.
} 
Essa espécie de intervenção contínua, portanto, ao mesmo tempo moral e militar, é realmente a forma lógica do exercício da força, que deriva de um paradigma de legitimação baseado num Estado de exceção permanente e de ação policial. As intervenções são sempre excepcionais, apesar de ocorrerem continuamente; elas tomam a forma de ações policiais, porque são voltadas para a manutenção de uma ordem interna. Dessa forma, a intervenção é um mecanismo eficaz que mediante ações policiais contribui diretamente para a construção da ordem moral, normativa e institucional do Império."419

Ainda que não existam declarações formais, exemplificativamente, de estados de guerra ou estados de sítio a justificar a suspensão de direitos e liberdades individuais, a lógica da segurança impõe esses mesmos estados em caráter fictício, mas plenamente efetivo. Aí reside justamente a nova técnica de governo: sob a doutrina do medo, que, para Slavoj ZIZEK, reflete o temor do imigrante, do crime, da depravação sexual, do Estado excessivo, da catástrofe ecológica ${ }^{420}$, enquanto para ZYGMUNT BAUMAN traduz qualquer espectro de vulnerabilidade - canto ou fresta de nossos lares, das ruas escuras ou das telas dos televisores, de pessoas que encontramos e de pessoas que não conseguimos perceber, de algo que ingerimos e do contato de nossos corpos e, sobretudo, a insegurança e a incerteza derivadas de um sentimento de impotência ${ }^{421}$-, o estado de exceção impera não porque exista um tumultus, mas porque ele pode surgir ou, pior, ele é administrado na medida da desordem determinada pelo soberano.

Sob o véu da salvaguarda da ordem jurídica, do Estado e do próprio estilo de vida Ocidental, cria-se uma desordem - emergência militar e, notadamente, a emergência econômica -, e se impõe a convicção de que a lei pode ser suspensa para que todas as medidas necessárias sejam satisfeitas. Como visto acima, é como se vivêssemos num totalitarismo filosófico - onde os campos, como articula HANNAH ARENDT “destinam-se não apenas a exterminar pessoas e degradar seres humanos, mas também servem à chocante experiência da eliminação, em condições cientificamente controladas, da própria

\footnotetext{
${ }^{419}$ HARDT, Michel; NEGRI, Antonio. Op. cit., p. 34-35, 36 e 57.

${ }^{420}$ ZIZEK, Slavoj. Violence. New York: Picador, 2008, p. 41.

${ }^{421}$ BAUMAN, Zygmunt. Medo líquido. Tradução de Carlos Alberto Medeiros. Rio de Janeiro: Jorge Zahar Ed., 2008, p. 11 e 167.
} 
espontaneidade como expressão da conduta humana",422 -, numa vestimenta de democracia declarada:

"A tese de uma íntima solidariedade entre democracia e totalitarismo (que aqui devemos, mesmo com toda a prudência, adiantar, não é, obviamente (como, por outra, aquela de Strauss sobre a secreta convergência entre liberalismo e comunismo quanto à meta final), uma tese historiográfica, que autorize a liquidação e o achatamento das enormes diferenças que caracterizam sua história e seu antagonismo; não obstante isto, no plano hitórico-filosófico que lhe é próprio, deve ser mantida com firmeza porque somente ela poderá permitir que orientemo-nos diante das novas realidades e das convergências imprevistas do fim do milênio, desobstruindo o campo em direção àquela nova política que ainda resta em grande parte inventar". ${ }^{423}$

Para Edson Luís DE Almeida Teles, foram os anos da Guerra Fria que incrementaram a substituição das declarações dos estados de exceção por doutrinas de segurança nacionais, tornando-as técnica de governo ${ }^{424}$. Isso se torna ainda mais evidente na América Latina, de acordo com DiEgo VALADÉs, uma vez que, superada a etapa do militarismo, as experiências históricas latinoamericanas tendem a confirmar “...la utilización de instrumentos constitucionales para restaurar formas autoritarias del poder, pero con la apariencia de avances democráticos",425. É justamente essa "máquina letal"426 o paradigma de governo atual que estaria levando o Ocidente a uma nova guerra mundial.

\footnotetext{
${ }^{422}$ ARENDT, Hannah. Origens do totalitarismo. Tradução de Roberto Raposo. São Paulo: Companhia das Letras, 1989, p. 488-489.

${ }^{423}$ AGAMBEN, Giorgio. Homo sacer: o poder soberano e a vida nua I. Tradução de Henrique Burigo. Belo Horizonte: Editora UFMG, 2002, p. 18.

${ }^{424}$ TELES, Edson Luís de Almeida. Brasil e África do Sul: os paradoxos da democracia. Memória política em democracias com herança autoritária. Tese de doutorado, Acervo Dedalus, FFLCH, 20900020892, SBD-FFLCH-USP 281499, 2007.

425 VALADÉS, Diego. Consideraciones sobre gobernabilidad y constitucionalismo: estudio introductorio. In: VALADÉS, Diego (Ed.). Gobernabilidad y constitucionalismo en América Latina. México: Universidad Nacional Autónoma de México, 2005, p. XL.

${ }^{426}$ AGAMBEN, Giorgio. Estado de exceção. Tradução de Iraci D. Poleti. São Paulo: Boitempo, 2004, p. 131.
} 


\subsubsection{Direitos de exceção e anomia jurídica}

Um esclarecimento deve ser feito quanto à suposta paridade entre direitos especiais ou direitos de exceção como resposta a uma crise - sejam esses direitos inscritos no direito positivo, sejam eles considerados um direito subjetivo do Estado ou do soberano, sejam eles considerados fontes da lei ou, ainda, sejam eles mero fato político - e o estado de exceção proposto por Agamben.

Consabido, é possível verificarmos precedentes históricos de sistemas de crises desde a Antiguidade: “... desde tempos de antanho, anota Pontes de Miranda, hebreus, cartagineses e gauleses, diante das circunstâncias anormais, elegiam magistrados extraordinários, com poderes quase ilimitados, para pôr cobro às situações que colocavam em risco a sobrevivência daquelas gentes" $" 427$. NAGIB SLAIBI FILHO explica que, longe do exercício desenfreado de poder, a ditadura constitucional romana - que, para JORGE BACELAR GOUVEIA, influenciou a elaboração de normas posteriores ${ }^{428}$ - ressumava previsão jurídica de responsabilidade do magistrado extraordinário e consequências do exercício do poder em correlatas condições extraordinárias ${ }^{429}$. De acordo com NORBERTO Bоввіо, o dictator romano é um magistrado extraordinário, mas legítimo, pois sua instituição era prevista pela constituição e o seu poder justificado pelo estado de necessidade. A exorbitância do poder do ditador era contrabalançada pela sua temporaneidade ${ }^{430}$ : não por outra razão temos o exemplo de Lucius Quinctius Cincinnatus, que, nomeado ditador pelo prazo de seis meses, renunciou em 16 dias, após a derrota dos inimigos. Na Grécia, temos a figura da esimnetia, também chamada de despotismo eletivo, enquanto na Idade Média encontramos os comissários pontifícios da Igreja Católica, a quem era confiado o governo de uma província para restabelecimento da tranquilidade pública e da paz ${ }^{431}$.

Outros exemplos poderiam ser citados, mas essa não é a nossa intenção. Para Agamben, entretanto, "Somente com os modernos é que o estado de necessidade tende a

\footnotetext{
${ }^{427}$ AMARAL SANTOS, Moacyr. O Estado de emergência. São Paulo: Revista dos Tribunais, 1981, p. 27. ${ }^{428}$ In: O estado de exceção no direito constitucional. v. I, p. 110.

${ }^{429} \mathrm{In}$ : Estado de defesa e Estado de sítio: estudos e comentários. In: Revista Forense, v. 306, p. 333.

${ }^{430}$ In: Estado, governo, sociedade: por uma teoria geral da política. Tradução de Marco Aurélio Nogueira. Rio de Janeiro: Paz e Terra, 1987, p. 159.

${ }^{431}$ Cf. Olavo Alves FERREIRA. In: Sistema constitucional de crises: restrições a direitos fundamentais. Rio de Janeiro: Forense; São Paulo: Método, 2009, p. 33.
} 
ser incluído na ordem jurídica e a apresentar-se como verdadeiro 'estado' da lei. $O$ princípio de que a necessidade define uma situação particular em que a lei perde sua vis obligandi (esse é o sentido do adágio necessitas legem non habet) transforma-se naquele em que a necessidade constitui, por assim dizer, o fundamento último e a própria fonte da lei ${ }^{4,432}$.

Sequencialmente, adveio o movimento do constitucionalismo, que, na acepção de José Johquim Gomes Canotilho, se imbricou com o sistema de crises: " $A$ Constitucionalização do direito de necessidade estadual considera-se a solução mais conforme com a 'idéia constitucional', porque é preferível ser a Constituição a consagrar e a definir os pressupostos do estado de exceção, a ter de recorrer-se a princípios de necessidade extra ou supraconstitucional, susceptiveis de manipulação a favor de uma qualquer 'razão de Estado' ou de 'segurança pública",433.

Há diferentes classificações doutrinárias dos sistemas constitucionais de crise e de legítima defesa do Estado e, em alguns casos, apenas distintas denominações. CANOTILHO $^{434}$ aponta três formas de constitucionalização das circunstâncias excepcionais no Direito Comparado: a de inexistência ou insuficiência de positivação constitucional acerca das situações de necessidade e respectivos poderes necessários, cujo exemplo mais relevante seria a Constituição dos Estados Unidos com poderes implícitos ou cláusula geral dos poderes de guerra; a de normatização constitucional de cláusula de plenos poderes ou de cláusula de ditadura, cujos exemplos basilares seriam a Constituição de Weimar (artigo 48) e a Constituição francesa de 1959 (artigo 16); a de previsão constitucional das situações de crise e do respectivo regime jurídico de anormalidade, com prefixação da competência dos executores, dos pressupostos, das formas, dos limites e dos efeitos. Esse autor elenca algumas expressões arroladas em diferentes sistemas para designar o instituto jurídico ${ }^{435}$ : estruturas de exceção, estado e/ou direito de necessidade estadual, defesa da Constituição, defesa da República, suspensão das garantias individuais, defesa de segurança e ordem públicas, estado de exceção constitucional, proteção extraordinária do Estado.

\footnotetext{
${ }^{432}$ AGAMBEN, Giorgio. Estado de exceção. Tradução de Iraci D. Poleti. São Paulo: Boitempo, 2004, p. 43.

${ }^{433}$ In: Direito Constitucional. 5. ed. Coimbra: Almedina, 1992, p. 1.152.

${ }^{434}$ Op. Cit. p. 1.159

${ }^{435}$ Op. cit., p. 1.151 .
} 
Já PEDRO CRUZ VILLANON ${ }^{436}$ propõe duas espécies: o estado excepcional e a ditadura constitucional. Por sua vez, MANOEL GONÇALVES FERREIRA FILHO ${ }^{437}$ assinala três sistemas constitucionais de crise - estado de sítio, lei marcial e ditadura constitucional -, enquanto DIRCÊO TORRECILlAS RAMOS elenca a “... ditadura romana, a suspensão da constituição, a lei marcial, a suspensão do habeas corpus e o Estado de sítio"438. PINTO FERREIRA $^{439}$ faz outra classificação: o modelo francês êtat siége, o processo angloamericano da lei marcial, o modelo alemão dos poderes ditatoriais e o modelo italiano do stato di assedio.

Enfim, seja qual for o critério de classificação, seja o sistema rígido, em que as situações de crise são previstas, seja no sistema flexível, em que os poderes extraordinários não são tipificados, estejam os plenos poderes inscritos no direito positivo ou não ${ }^{440}$ - de maneira pretensamente completa, no caso de estados excepcionais, ou na forma de cláusulas abertas de poderes extraordinários -, parece-nos que há convergência doutrinária no sentido de que requisitos como necessidade, temporariedade, adequação e proporcionalidade devem ser observados pelas medidas de exceção. De outra forma, "sem que se verifique a necessidade, o estado de exceção configurará puro golpe de estado, simples arbitrio" ${ }^{441}$. Para OLGÁRIA MATOS, a guerra permanente criada pelos Estados Unidos da América é um bom exemplo desse arbítrio, ou melhor, de uma necessidade administrada:

\footnotetext{
${ }^{436}$ VILLANON, Pedro Cruz. Estados excepcionales y suspension de garantias. Madrid: Editorial Tecnos, $1984, \mathrm{p} 31$.

${ }^{437}$ Para esse autor, o estado de sítio, criado pelo Decreto de 10 de julho de 1791 e recepcionado pela Constituição francesa de 1791, constitui-se em medida de suspensão temporária e localizada de certas garantias constitucionais em situações de crise estipuladas na própria Constituição, razão pela qual é incorporado essencialmente pelos países de civil law. A lei marcial, com raízes na Inglaterra e extensão ao direito estadunidense, significa sobreposição das autoridades militares sobre as civis, com adoção das mais amplas medidas necessárias para contenção das situações de crise, sem, contudo, importar em sistema sui generis. A ditadura constitucional, como sistema menos utilizado, guardaria origem na ditadura romana e, mais na atualidade, teria correspondido à suspensão adotada pela Constituição francesa de 1799, pela Constituição chilena de 1833 e pela Carta Constitucional de 1937. In: Curso de Direito Constitucional. 30. ed. São Paulo: Saraiva, 2003, p. 330.

${ }^{438}$ In:Direitos fundamentais nas crises. In: MARTINS, Ives Gandra da Silva (coord.). As vertentes do direito constitucional contemporâneo. São Paulo: América Jurídica, 2002, p. 493.

${ }^{439}$ FERREIRA, Luis Pinto. Princípios gerais de direito constitucional moderno, Tomo I. São Paulo: Editora RT, p. 85.

${ }^{440}$ Neste ponto, concordamos com a posição de Gilberto Bercovici, para quem toda previsão legislativa de exceção é inútil, pois trata de algo que, na realidade, não pode dar conta, porquanto depende do respaldo político e não jurídico. In: Soberania e constituição: para uma crítica do constitucionalismo. São Paulo: Quartier Latin, 2008, p. 40.

${ }^{441}$ SILVA, José Afonso da. Curso de direito constitucional positivo. 23. ed. São Paulo: Malheiros, 2003, p. 742.
} 
"Tudo ocorre como se a Constituição tivesse sido concebida tendo em mente o estado de exceção, e a energia republicana não passasse de um estado de exceção represado. E o 11 de setembro foi 'providencial' para instaurar a 'cultura do pânico' e a expansão territorial a partir da Constituição americana de autolouvação evangélica. Desse modo, o problema não seria George W. Bush, mas a Constituição a permitir a violência purificadora, a retirada de todas as proteções constitucionais, sendo o Executivo, agora abertamente, 'investigador, promotor de justiça, juiz, júri, carcereiro e executor'... Os Estados Unidos da América do Norte, em guerra permanente, estariam acelerando a história na direção de um final glorioso, da mesma maneira que a limpeza dos hereges simplifica o caminho do triunfo da verdade redentora. Quando se acredita na posse da verdade, não a impor àqueles incapazes de vêla é um lamentável retardamento do final feliz. Sobre essa base se constrói boa parte da paixão política norte-americana. Só o Ocidente pode aspirar ao paraíso, só a racionalidade técnica nos dará o bem-estar definitivo. A ideologia norte-americana realiza com perfeição o Estado 'totalitário' em seu sonho de unir na terra o poder e o absoluto, o teológico e o político." ${ }^{442}$

Entretanto, entender o estado de exceção agambeniano como uma função da necessidade implica conclusões equivocadas, seja do ponto de vista da vida ou do ponto de vista da norma jurídica. O estado de exceção agambeniano transcende o estado de emergência, o estado de calamidade pública, o estado de guerra e o estado de sitio em sua indeterminação ${ }^{443}$, muito embora o autor use o mesmíssimo termo para qualificar os estados de exceção declarados do século XX, gerando dúvidas ao leitor ${ }^{444}$.

O estado de exceção agambeniano “... não só sempre se apresenta muito mais como uma técnica de governo do que como uma medida excepcional, mas também deixa aparecer sua natureza de paradigma constitutivo da ordem jurídica" ${ }^{\text {445 }}$. Agamben explica essa transcendência quando de sua firme tomada de posição quanto ao termo stato di eccezione:

\footnotetext{
${ }_{442}^{44}$ MATOS, Olgária. Op. cit., p. 46.

${ }^{443}$ Cf. GULLI, Bruno. Op. cit., p. 235.

${ }^{444}$ Não são poucas as vezes em que Agamben chama, a título de exemplo, a ditadura constitucional de estado de exceção. Entretanto, como declinado acima, o estado de exceção hodierno agambeniano não é um estado de direito, mas um estado sem direito.

${ }^{445}$ AGAMBEN, Giorgio. Estado de exceção. Tradução de Iraci D. Poleti. São Paulo: Boitempo, 2004, p. 18.
} 
"À incerteza do conceito corresponde exatamente a incerteza terminológica. O presente estudo se servirá do sintagma 'estado de exceção' como termo técnico para o conjunto coerente dos fenômenos jurídicos que se propõe a definir. Esse termo, comum na doutrina alemã (Ausnahmezustand, mas também Notstand, estado de necessidade), é estranho às doutrinas italiana e francesa que preferem falar de decretos de urgência e de estado de sítio (político ou fictício, état de siège fictif). Na doutrina anglo-saxônica, prevalecem, porém, os termos martial law e emergency powers. Se, como se sugeriu, a terminologia é o momento propriamente poético do pensamento, então as escolhas terminológicas nunca podem ser neutras. Nesse sentido, a escolha da expressão 'estado de exceção' implica uma tomada de posição quanto à natureza do fenômeno que se propõe a estudar e quanto à lógica mais adequada à sua compreensão. Se exprimem uma relação com o estado de guerra que foi historicamente decisiva e ainda está presente, as noções de 'estado de sítio' e de 'lei marcial' se revelam, entretanto inadequadas para definir a estrutura própria do fenômeno e necessitam, por isso, dos qualificativos 'político' ou 'fictício' um tanto equívocos. O estado de exceção não é um direito especial (como o direito de guerra), mas, enquanto suspensão da própria ordem jurídica, define seu patamar ou seu conceito-limite., ${ }^{446}$

O estado de exceção não é um direito especial fundamentado numa necessidade, seja fictícia ou política - na lógica da potencialidade acima apresentada, necessidade apresenta-se como um não ser capaz de não-ser (non poter non essere) ${ }^{447}$. O estado de exceção agambeniano não é um estado de direito, ainda que excepcional, muito menos abalizado num estado de necessidade ou num direito subjetivo do Estado, mas um estado sem direito, quer dizer, uma anomia. A necessidade em Agamben “... não é fonte de lei e tampouco suspende, em sentido próprio, a lei; ela se limita a subtrair um caso particular à aplicação literal da norma ${ }^{\text {"448 }}$. Destarte, Agamben negará o pensamento de juristas, como italiano Santi Romano, que concebe a necessidade não só como não estranha ao

\footnotetext{
${ }_{446}^{46}$ AGAMBEN, Giorgio. Estado de exceção. Tradução de Iraci D. Poleti. São Paulo: Boitempo, 2004, p. 14. ${ }^{447} \mathrm{CF}$. Giorgio AGAMBEN. La comunità che viene. Turim: Bollati Boringhieri, p. 38

${ }^{448}$ AGAMBEN, Giorgio. Estado de exceção. Tradução de Iraci D. Poleti. São Paulo: Boitempo, 2004, p. 41.
} 
ordenamento jurídico, mas também como fonte primária e originária da lei - necessitas legem non habet.

De fato, parece-nos que, seja a necessidade uma figura da ordem jurídica ou uma figura extrajurídica, seja ela inscrita no direito positivo ou não - na forma de estado de necessidade, mas ainda assim inscrita na ordem jurídica ${ }^{49}$-, o conceito não sobrevive ao argumento de que seu conteúdo é determinado por um juízo subjetivo e se esgota numa vontade externada. Na doutrina agambeniana, não há que se confundir, portanto, estado de guerra, de sítio ou de emergência e estado de exceção, uma vez que este, conquanto seja uma figura da necessidade, não pode se balizar na teoria da necessidade. O estado de exceção agambeniano não é um estado de direito, mas um estado sem direito.

É assim que as democracias européias e, principalmente, a estadunidense, estão a concretizar uma nova técnica de governo abalizada unicamente na pretensa necessidade, um conceito subjetivo esvaziado numa decisão, que, na visão de Agamben, ao contrário de Schmitt, não é justificativa a súbitas medidas arbitrárias, mas, a bem da verdade, ferramenta de um contínuo estado de exceção: quando os argumentos da emergência são utilizados para todo tipo de crise, os limites entre normalidade e exceção são ultrapassados e a emergência vira regra ${ }^{450}$.

Para Agamben, "embora um uso provisório e controlado dos plenos poderes seja teoricamente compatível com as constituições democráticas, 'um exercício sistemático e

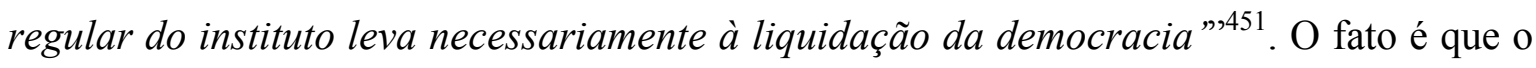
estado de exceção agora tornou-se a regra. Em suma, Agamben nega qualquer tentativa de fundamentar o estado de exceção na necessidade ou no status necessitatis. Para o filósofo, “... portanto, são falsas todas aquelas doutrinas que tentam vincular diretamente o estado de exceção ao direito, o que se dá com a teoria da necessidade como fonte jurídica

449 TÉRCIO SAMPAIO FERRAZ JR. coloca a necessidade da seguinte maneira: “... Afinal, que é necessidade, na expressão: estado de necessidade? Não é uma noção jurídica. Estado de necessidade o é, mas a necessidade, à qual se faz referência, com toda a sua força de fato, como algo que ninguém segura, parece justamente de que estamos falando quando falamos de poder. E na noção de estado de necessidade, ou na noção de estado de sítio talvez se ache uma curiosa pista para nos mostrar que, na relação entre poder e direito, um não se reduz totalmente ao outro". In: Estudos de filosofia do direito: reflexões sobre o poder, a liberdade, a justiça e o direito. 3 ed. São Paulo: Atlas, 2009, p. 30-31.

${ }^{450}$ Cf. BERCOVICI, Gilberto. Soberania e constituição: para uma crítica do constitucionalismo. São Paulo: Quartier Latin, 2008, p. 328.

${ }^{451}$ AGAMBEN, Giorgio. Estado de exceção. Tradução de Iraci D. Poleti. São Paulo: Boitempo, 2004, p. 19. 
originária, e com a que vê no estado de exceção o exercício de um direito do Estado à própria defesa ou a restauração de um originário estado pleromático do direito (os "plenos poderes")... O estado de necessidade não é um 'estado do direito', mas um espaço sem direito" ${ }^{, 452}$.

\subsubsection{Estado de exceção, linguagem e força-de-lei}

Outro elemento caracterizador do estado de exceção agambeniano é a natureza de pura potencialidade da norma jurídica. Para o pensador, a validade da norma jurídica não coincide com sua aplicação ao caso particular, mas - justamente por possuir um caráter geral - independe do caso particular.

Grosso modo, na proposição jurídica que ordena, por exemplo, não fazer $X$, existe igualmente um não não fazer $X$ nela pressuposta (potência versus impotência, esta como parte da própria potência, como visto acima). $\mathrm{O}$ fato não-jurídico consistente na conduta não não fazer $X$ se juridiciza exatamente porque a norma o exclui mediante sua inclusão. Disso resulta que o jurídico pressupõe o não-jurídico em tal medida que careceria mesmo de sentido insistir em oposições entre norma e fato ${ }^{453}$. Com isso em mente, Agamben traça um paralelo entre direito e linguagem nos moldes hegelianos ${ }^{454}$, criando um estado de exceção linguístico ${ }^{455}$ :

"Como uma palavra adquire o poder de denotar, em uma instância de discurso em ato, um segmento da realidade, somente porque ela tem sentido até mesmo no próprio não-denotar (isto é, como langue distinta de parole: é o termo na sua mera consistência lexical, independentemente de seu emprego concreto no discurso), assim a norma pode referir-se ao caso particular somente porque, na

\footnotetext{
${ }^{452}$ AGAMBEN, Giorgio. Estado de exceção. Tradução de Iraci D. Poleti. São Paulo: Boitempo, 2004, p. 79.

${ }^{453}$ Cf. Paulo Roberto dos Santos CABRAL. In: Teoria constitucional e exceção permanente: uma categoria para a teoria constitucional do século XXI. Curitiba: Jaruá, 2009, p. 142.

${ }^{454}$ Aliás, o próprio Agamben expõe que "Hegel foi o primeiro a compreender em profundidade esta estrutura pressuponente da linguagem, graças à qual ela está, ao mesmo tempo, fora e dentro de si mesma..." In: Homo sacer: o poder soberano e a vida nua I. Tradução de Henrique Burigo. Belo Horizonte: Editora UFMG, 2002, p. 28.

${ }^{455}$ Para Giorgio AGAMBEN, "Em qualquer âmbito o pensamento de nosso tempo se encontra confrontado com a estrutura da exceção. A pretensão de soberania da linguagem consistirá então na tentativa de fazer coincidir o sentido com a denotação, de estabelecer entre estes uma zona de indistinção, na qual a língua se mantém em relação com seus denotata abandonando-os, retirando-se destes em uma pura langue (o 'estado de exceção' lingüístico)". In: Homo sacer: o poder soberano e a vida nua I. Tradução de Henrique Burigo. Belo Horizonte: Editora UFMG, 2002, p. 33.
} 
exceção soberana, ela vigora como pura potência, na suspensão de toda referência atual." ${ }^{, 456}$

Ora, se acima foi dito que toda potencialidade pressupõe a impotencialidade (de outra forma a potencialidade já seria ato), então a linguagem pressupõe o não-linguístico (de outra forma já seria discurso), assim como a norma pressupõe o não-normativo (de outra forma já seria decisão). Linguagem e norma jurídica vivem, assim, na indistinção entre potencialidade e impotencialidade.

Em outras palavras, no raciocínio agambeniano, assim como a linguagem pressupõe o não-linguístico - um discurso mantido em suspenso numa mera potencialidade - para sua denotação num ato, a lei pressupõe o não-jurídico - “por exemplo, a mera violência enquanto estado de natureza" ${ }^{, 457}$ - como aquilo que permanece em suspenso no estado de exceção:

"Like law, language secures its reference to the world through the possibility of its own suspension, through its ability to subsist as an abstract body of rules independently of any act of discourse."

Ao citar o exemplo acima, queremos crer que Agamben não pretende levantar questões sobre o direito natural ${ }^{459}$, mas simplesmente comprovar uma vez mais a existência de uma zona de indiferença qualificadora da exceção. $\mathrm{O}$ escopo do filósofo italiano é, na verdade, demonstrar a relação de esclusione inclusiva inerente ao estado de exceção e à linguagem, pois “também a linguagem mantém o homem em seu bando, porque, enquanto falante, ele já entrou desde sempre nela sem que pudesse dar-se conta. Tudo aquilo que se pressupõe à linguagem (na forma de um não-linguístico, de um inefável etc.) não é, aliás, nada mais que um pressuposto da linguagem "460.

\footnotetext{
${ }^{456}$ AGAMBEN, Giorgio. Homo sacer: o poder soberano e a vida nua I. Tradução de Henrique Burigo. Belo Horizonte: Editora UFMG, 2002, p. 28.

${ }^{457}$ AGAMBEN, Giorgio. Homo sacer: o poder soberano e a vida nua I. Tradução de Henrique Burigo. Belo Horizonte: Editora UFMG, 2002, p. 28.

${ }^{458}$ WHYTE, Jessica. Op. cit., p. 74.

${ }^{459}$ Isso fica claro ao determinar que " $A$ exceção soberana (como zona de indiferença entre natureza e direito) é a pressuposição da referência jurídica na forma de sua suspensão", e restará mais cristalino ao examinarmos a releitura que Agamben dá ao estado de natureza hobbesiano.

${ }^{460}$ AGAMBEN, Giorgio. Homo sacer: o poder soberano e a vida nua I. Tradução de Henrique Burigo. Belo Horizonte: Editora UFMG, 2002, p. 58.
} 
A relação entre norma e realidade implica a suspensão da norma, assim como a relação entre linguagem e mundo implica a suspensão da denotação sob a forma de uma langue $^{461}$. Se a decisão soberana sobre o estado de exceção inaugura o espaço onde interno e externo se entrelaçam e determinadas normas podem ser aplicadas ao caso particular, somente na língua como pura potência de significar - livre de toda concreta instância do discurso - o linguístico e o não-linguistico se tornam indiferentes a permitir que certos termos possam corresponder a determinados significados:

“A linguagem é o soberano que, em permanente estado de exceção, declara que não existe um fora da língua, que ela está sempre além de si mesma. A estrutura particular do direito tem seu fundamento nesta estrutura pressuponente da linguagem humana. Ela exprime o vínculo de exclusão inclusiva ao qual está sujeita uma coisa pelo fato de encontrar-se na linguagem, de ser nominada. Dizer, neste sentido, é sempre um ius dicere." ${ }^{462}$

Desse modo, a lei, na sua pura potencialidade, perde toda significação, isolada dos usos e hábitos concretos dos indivíduos, porquanto flutua numa indiscernibilidade linguística:

“Assim como os elementos linguísticos existem na língua sem nenhuma denotação real, que só adquirem no discurso em ato, também no estado de exceção a norma vige sem nenhuma referência à realidade. Porém, assim como a atividade lingüística concreta torna-se inteligível pela pressuposição de algo como uma língua, a norma pode referir-se à situação normal pela suspensão da aplicação no estado de exceção."

Podemos agora entender, com mais razão, a definição agambeniana do homem político: “A política existe porque o homem é o vivente que, na linguagem, separa e opõe a si a própria vida nua e, ao mesmo tempo, se mantém em relação com ela numa exclusão

\footnotetext{
${ }^{461}$ Cf. Giorgio AGAMBEN. In: Estado de exceção. Tradução de Iraci D. Poleti. São Paulo: Boitempo, 2004, p. 93.

${ }_{462}$ AGAMBEN, Giorgio. Homo sacer: o poder soberano e a vida nua I. Tradução de Henrique Burigo. Belo Horizonte: Editora UFMG, 2002, p. 29.

${ }^{463}$ AGAMBEN, Giorgio. Estado de exceção. Tradução de Iraci D. Poleti. São Paulo: Boitempo, 2004, p. 59.
} 
inclusiva" ${ }^{464}$ (Vi è politica, perché l'uomo è il vivente che, nel linguaggio, separa e oppone a sé la propria nuda vita e, insieme, si mantiene in rapporto con essa in un'esclusione inclusiva).

É nesse sentido que ANTON SCHÜTZ concebe uma determinada identidade entre a norma pressuposta de Kelsen e o estado de exceção de Agamben. Para o autor, a Grundnorm kelseniana seria o equivalente legal dos shifters linguísticos, que, por sua vez, revelariam sua similitude com o estado de exceção agambeniano. Em outras palavras, da mesma maneira que o shifter não é parte da mensagem que ele mesmo possibilita, a norma fundamental kelseniana não é parte da ordem jurídica por ela inaugurada. Mutatis mutandis, a norma agambeniana, enquanto suspensa no estado de exceção, se aproximaria de uma mesma identidade ${ }^{465}$.

Essa comparação é questionável, até mesmo porque seu autor assevera que Kelsen nunca teria sido mencionado por Agamben - "a twentieth-century legal philosopher and constitutionalist - never mentioned by Agamben..." ${ }^{466}$-, o que é incorreto, uma vez que Kelsen é mencionado, ainda que numa única oportunidade, salvo melhor juízo, na vastidão de sua obra, em Homo sacer ${ }^{467}$. Como visto acima, Agamben refuta Kelsen expressamente. Entretanto, tendemos a concordar que o mesmo furor - um shocking insult to lawyers outrora causado por advogados contra a norma pressuposta como fundamento da ordem jurídica é agora aplicado ao estado de exceção agambeniano.

Mas, na suspensão da lei, o que resta? Ao considerar que, no momento da suspensão da ordem jurídica, há ações que escapam a uma significação jurídica, ou seja, ações cuja referência é um vazio de direito, o que resta então é pensar numa forza-di-legge, um elemento que, separado da lei - há aqui o divórcio entre potência e ato, como expressa BRETT NEILSON ${ }^{468}$ e LELAND DE LA DURANTAYE, assim como no estado de exceção

${ }^{464}$ AGAMBEN, Giorgio. Homo sacer: o poder soberano e a vida nua I. Tradução de Henrique Burigo. Belo Horizonte: Editora UFMG, 2002, p. 16.

${ }^{465}$ Cf. Anton SCHÜTZ. In: The fading memory of homo non sacer. In: CLEMENS, Justin; HERON, Nicholas; MURRAY, Alex (ed.). The work of Giorgio Agamben: law, literature, life. Edinburg University Press, 2008, p. 123.

${ }^{466}$ SCHÜTZ, Anton. Op. cit., p. 123.

${ }^{467}$ Cf. Giorgio AGAMBEN. In: Homo sacer: o poder soberano e a vida nua I. Tradução de Henrique Burigo. Belo Horizonte: Editora UFMG, 2002, p. 35.

468 "There is a radical separation between potential and act as well as a mystical element or fiction that seeks to eliminate this disconnection. Far from leading back to the legal order, as Schmitt contends, the state of exception exhibits the 'impossible conjuncture' between norm and reality, or between the law and its 
potência e ato estão separados radicalmente ${ }^{469}$ (Una tal forza-di-legge, in cui la potenza e l'atto sono radicalmente separati) -, signifique o momento no qual o direito tenta incluir em si sua própria ausência e, com isso, relacionar-se com o estado de exceção. ${ }^{470}$

Segundo Agamben, muito embora a figura da força-de-lei tenha existência autônoma em relação à lei desde o direito romano, é somente no contexto da Revolução Francesa que, em sentido técnico, o sintagma se refere “... não à lei, mas àqueles decretos que têm justamente, como se diz, força de lei - que o poder executivo pode, em alguns casos - particularmente no estado de exceção - promulgar" ${ }^{\prime 471}$. Essa conceituação distingue, assim, a essência da norma jurídica de sua vis obligandi, ou seja, de sua aplicabilidade. Para JESSICA WHYTE, "Law can only apply to life through an act of application, which is not contained within the law" ${ }^{\text {"72 }}$, diferenciação essa que adquire especial relevo na progressiva abolição da distinção entre poder legislativo, poder executivo e poder judiciário, "uma das figuras do estado de exceção",473.

Note-se, contudo, que a confusão nas democracias hodiernas entre atos executivos e legislativos para Agamben não revela per se, em nossa leitura, o estado de exceção diferentemente da respeitável interpretação de outrem ${ }^{474}$-, mas somente uma de suas

application. It is a limit zone where logic and practice intermingle and a pure violence without logos activates an enunciation with no real referent." NEILSON, Brett. Review by Brett Neilson (University of Western Sydney). Disponível em http://www.generation-online.org/p/fpagambenreviewed.htm. Acessado em 5.8.2009.

${ }^{469}$ Cf. Leland de la DURANTAYE. Op. cit., p. 340.

${ }^{470}$ Cf. CHUERI, Vera Karam de. Op. cit., p. 97

${ }^{471}$ AGAMBEN, Giorgio. Estado de exceção. Tradução de Iraci D. Poleti. São Paulo: Boitempo, 2004, p. 60.

${ }^{472}$ WHYTE, Jessica. Op. cit., p. 70.

${ }^{473}$ AGAMBEN, Giorgio. Estado de exceção. Tradução de Iraci D. Poleti. São Paulo: Boitempo, 2004, p. 60.

${ }^{474}$ Para Vitor Hugo Nicastro HONESKO, Raquel Schlommer HONESKO e Tatiane Alves BARBOSA, “...o estado de exceção mina completamente as bases do Estado Democrático de Direito proclamado pela Constituição de 1988. Além de desnudar a soberania popular, o estado de exceção faz com que a harmonia e a independência entre os Poderes da União sejam abaladas seriamente: há uma abolição da distinção entre Poder Legislativo, Executivo e Judiciário... No Brasil, quando se analisa a freqüente edição de medidas provisórias pelo Presidente da República, constata-se sem esforços esta expansão dos poderes do Executivo.

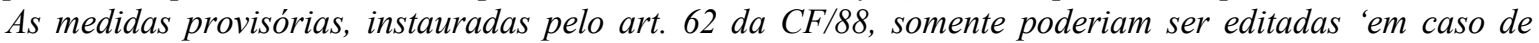
relevância e urgência'. Todavia, a prática deste instituto demonstra um exagerado uso de um instrumento que nem deveria existir no regime presidencialista brasileiro. Só para se ter uma idéia do (ab)uso das medidas provisórias pelo Presidente da República, interessante se faz analisar a quantidade de edições desas medidas após a promulgação da Constituição de 1988. É de se notar, no entanto, que após a EC 32, de 11.09.2001, ficou proibida a reedição de medidas provisórias. Assim, com informações cedidas pela própria Presidência da República, se tem os seguintes quadros. O Presidente José Sarney, entre os meses de março de 1988 e março de 1990, editou 125 medidas provisórias, perfazendo uma média 5,21 medidas provisórias por mês. Fernando Collor de Mello, entre os meses de março de 1990 e outubro de 1992, editou 89 medidas provisórias, com uma média mensal de 2,92 medidas provisórias. O governo de Itamar Franco editou 142 medidas provisórias entre os meses de outubro de 1992 e dezembro de 1994. Média de 5.26 medidas provisórias por mês. Com o governo de Fernando Henrique Cardoso houve um aumento vertiginoso 
características especiais e, na verdade, um mal-entendido da política ocidental: “ $L e$ malentendu qui consiste à concevoir le gouvernement comme simple pouvoir exécutif est l'une des erreurs les plus lourdes de conséquences dans l'histoire de la politique occidentale $^{\text {"475 }}$. Por oportuno, para Agamben o limite dessa confusão é justamente “...o regime nazista em que, como Eichmann não cansava de repetir, 'as palavras do Führer têm força-de-lei [Gesetzeskraft]"476.

Pelo contrário, em que pese o reconhecimento de que essa confusão seja “... uma das características essenciais do estado de exceção - a abolição provisória da distinção entre poder legislativo, executivo e judiciário" ${ }^{477}$, Agamben é claro ao lecionar que a emergência do estado de exceção não se baseia nela, mas sim no isolamento da lei em relação à força de lei.

Isso porque, de um lado, temos uma norma jurídica que está em vigor e não se aplica, é dizer, pura potência que não tem força, e, de outro, encontramos atos que não têm validade de lei e possuem sua força. A força-de-lei não é a lei, mas ainda não é a vida. Por conseguinte:

“... a 'força-de-lei' flutua como um elemento indeterminado, que pode ser reivindicado tanto pela autoridade estatal (agindo como ditadura comissária) quanto por uma organização revolucionária (agindo como ditadura soberana).

da edição de medidas provisórias. O problema deste inflar de poderes legislativos no Executivo não se deu tanto com a edição das medidas provisórias, mas com as reedições destas. No primeiro governo de FHC (janeiro de 1995 a dezembro de 1998) foram editadas 160 medidas provisórias (média: 3,33 mensais). No entanto, as reedições chegaram ao espantoso número de 2.449, perfazendo uma média de 35,44 reedições de medidas provisórias por mês! O segundo governo de FHC (janeiro de 1999 a setembro de 2001), portanto, antes da EC 32/2001, editou 103 medidas provisórias (média: 3,12 mensais). Mas foram feitas 2.587 reedições destas medidas, gerando a absurda média de 78,39 reedições de medidas provisórias mensais! Quando do advento da EC 32/2001, proibindo as reedições de medidas provisórias, Fernando Henrique Cardoso aumentou a média de edições. Nos 15 meses restantes de seu governo houve a edição de 102 medidas provisórias (média: 6,8 mensais). Com o governo Luís Inácio Lula da Silva não houve modificação do estilo de governar, pois também estão sendo editadas muitas medidas provisórias. Entre os meses de janeiro de 2003 e outubro de 2005 foram editadas 159 medidas provisórias, atingindo a média de 4,96 medidas provisórias mensais”. HONESKO, Vitor Hugo Nicastro; HONESKO, Raquel Schlommer; BARBOSA, Tatiane Alves. Op. cit., p. 267.

${ }^{475}$ AGAMBEN, Giorgio. Note liminaire sur le concept de démocratie. In: Démocratie dans quel état? La Fabrique éditions, 2009, p. 12.

${ }^{476}$ AGAMBEN, Giorgio. Estado de exceção. Tradução de Iraci D. Poleti. São Paulo: Boitempo, 2004, p. 60. ${ }^{477}$ AGAMBEN, Giorgio. Estado de exceção. Tradução de Iraci D. Poleti. São Paulo: Boitempo, 2004, p. 19. 
O estado de exceção é um espaço anômico onde o que está em jogo é uma força de lei sem lei." ${ }^{478}$

É assim que a separação da lei de sua aplicação (potência versus ato) leva Agamben a criar o termo forza-di-legge, ou seja, força de lei sem lei, para descrever uma situação em que a força da lei não está amarrada à lei per se, mas, ao invés, encontra-se como um elemento indeterminado. Não por outra razão Agamben defende que "a aplicação de uma norma não está de modo algum contida nela e nem pode ser dela deduzida, pois, de outro modo, não haveria necessidade de se criar o imponente edificio do direito processual” ${ }^{, 79}$. Como entre a linguagem e o mundo, potência e ato, também entre a norma e a sua aplicação não há nenhuma relação de internamento que permita fazer decorrer diretamente uma da outra, mas somente uma exclusão inclusiva.

Se isso é verdade, o que uniria potência e ato, lei e realidade? Demonstrada a separação entre esses elementos, o estado de exceção é justamente a abertura do espaço entre eles e o seu preenchimento por uma pura força-de-łei, que realiza uma norma jurídica cuja aplicação foi suspensa. Esse elementos se tornam, assim, indiscerníveis. Para CATHERINE MiLls, a chave para se compreender a contiguidade e coincidência entre lei e vida na visão de Agamben encontra-se na interpretação de Walter Benjamin e Gershom Scholem quanto aos escritos de Franz Kafka:

"The two readings of Kafka proposed by Benjamin and Scholem are, for Agamben, the extreme points that any inquire into the relation between life and law must confront, and for his part, in taking up this disagreement, he proposes a kind of reapprochement of their seemingly opposed conceptions. Taking up the phrase of "being in force without significance" that Scholem proposed as a way of articulating the inscrutability of law in Kakfa's writings, Agamben argues that this provides the most accurate conception of the status of law in the state of exception characteristic of the contemporary age. What he means by this phrase is that the law has effectively been emptied of any determinate content, such that the object upon which it might be applied is itself no longer in existence. This introduces problem not dissimilar to the void of the

\footnotetext{
${ }^{478}$ AGAMBEN, Giorgio. Estado de exceção. Tradução de Iraci D. Poleti. São Paulo: Boitempo, 2004, p. 61.
} ${ }^{479}$ AGAMBEN, Giorgio. Estado de exceção. Tradução de Iraci D. Poleti. São Paulo: Boitempo, 2004, p. 63. 
exception identified by Schmitt, in that the application of the law is definitively detached from the form of law. Crediting Kant with introducing the law in force without significance to modernity in his attempt to isolate the pure form of law apart from any particular content, Agamben proposes that the reduction of law to a purely formal principle of universal applicability means not that the law is no longer in force, but that it appear only 'in the form of its own unrealizability', that is 'applies in no longer applying'. However, this points to the Benjaminian side of the disagreement, wherein Benjamin proposes that a law in force without significance is itself indistinguishable from life. Benjamin`s interpretation of Kafka emphasizes that the indecipherability or inaccessibility of law is equivalent to its nullity, such that law no longer maintains any transcendence over life but is wholly coincidental with it." 480

Ao possuir força sem significância, a lei não é ausente, mas esvaziada de qualquer conteúdo positivo ou significado, e suspensa em sua própria aplicação. Não se trata de inaplicação como num estado sem lei, mas sim que, enquanto aplicada, a lei não o faz em qualquer sentido concreto ou imediato uma vez que perdeu toda sua inteligibilidade.

Agamben conclui dessas posições contrastantes que há uma correlação essencial entre vida sob uma lei em vigor sem significância e vida na exceção soberana, no momento em que nenhuma dessas situações permitem que a vida e a lei sejam distinguíveis: no estado de exceção, lei sem significância passa à vida enquanto vida sempre subsiste em relação à lei. Agamben não está simplesmente sugerindo que a vida natural ou biológica funda a existência da lei. Pelo contrario, a figura determinante da exclusão inclusiva é a vida nua, entendida como zona de indistinção pela qual vida política e vida natural se articulam.

Com base nesse pensamento, Agamben generaliza a exceção soberana de maneira que ela aparece não mais como um caso excepcional, mas como a regra. Isso significa que a captura da vida nua dentro da exceção é a condição geral da existência, de modo que a regra e a exceção, inclusão e exclusão, direito e violência, não são mais distinguíveis.

${ }^{480}$ MILLS, Catherine. Biopolitics, liberal eugenics, and nihilism. In: CALARCO, Matthew; DECAROLI, Steven (ed.). Giorgio Agamben: sovereignty and life. Stanford, California: Stanford University Press, 2007. p. 192. 


\subsubsection{Biopolítica, norma e exceção}

Como analisado acima, Foucault sustenta que o controle social do corpo no Ocidente assumiu um novo arquétipo a partir do fim do século XVII, de maneira que a concepção aristotélica do homem enquanto animal dotado de uma capacidade adicional de fazer política foi definitivamente superada, tornando a vida biológica objeto e alvo do poder político.

Foi igualmente dito que a transformação da política, segundo Foucault, deu-se por meio do surgimento de técnicas disciplinares quanto ao indivíduo e, ato contínuo, pela biopolítica quanto à população: a fabricação de corpos submissos e exercitados, ou seja, de corpos dóceis ${ }^{481482}$. Como se relacionam então norma e disciplina e, por derradeiro, norma e biopolítica, de maneira a as relacionarmos à exceção?

Ambos os eventos - disciplina e biopolítica -, exterioriza Foucault, resultam no surgimento de uma sociedade normalizadora em paralelo a uma regressão jurídica ${ }^{483}$. Esse biopoder normalizador assinala novos padrões de regulação social: não mais opera por meio da violência imposta nos sujeitos de cima para baixo ${ }^{484}$ - superação do suplício -, mas por meio de uma regulação normalizadora que administra e patrocina a vida dos sujeitos.

Nesse novo regime, o poder se autoincorpora no corpo do cidadão por meio da regulação normativa ou normalização dos processos da vida, e não por meio da lei.

\footnotetext{
${ }^{481}$ Cf. Michel FOUCAULT. In: Vigiar e Punir: nascimento da prisão. Tradução de Raquel Ramalhete. 36 ed. Rio de Janeiro: Vozes, 2009, p. 133.

${ }^{482}$ Para Giorgio AGAMBEN, "Foucault assim mostrou como, numa sociedade disciplinar, os dispositivos visam, através de uma série de práticas e discursos, de saberes e de exercícios, à criação de corpos dóceis, mas livres, que assumem a sua 'identidade' e a sua liberdade de sujeitos no próprio processo de assujeitamento". In: O que é contemporâneo? e outros ensaios. Tradução Vinícius Nicastro Honesko. Chapecó: Argos, 2009. p. 46.

483 "Uma sociedade normalizadora é o efeito histórico de uma tecnologia de poder centrada na vida. Por referência às sociedades que conhecemos até o século XVIII, nós entramos em uma fase de regressão jurídica; as Constituições escritas no mundo inteiro a partir da Revolução francesa, os Códigos redigidos e reformados, toda uma atividade legislativa permanente e ruidosa não devem iludir-nos: são formas que tornam aceitável um poder essencialmente normalizador". FOUCAULT, Michel. História da sexualidade I: vontade de saber. Tradução de Maria Thereza da Costa Albuquerque e J. A. Guilhon Albuquerque. 19. ed. Rio de Janeiro: Graal, 1988, p. 157.

484 "O poder está em toda parte; não porque englobe tudo e sim porque provém de todos os lugares". FOUCAULT, Michel. História da sexualidade I: vontade de saber. Tradução de Maria Thereza da Costa Albuquerque e J. A. Guilhon Albuquerque. 19. ed. Rio de Janeiro: Graal, 1988, p. 103.
} 
Segundo RicARdo Marcelo FonsecA, “... a 'sociedade de normalização' não é um conceito ou uma categoria que conste dos manuais de teoria do Estado ou de teoria do direito tradicionais. Seu significado é algo ignorado e até mesmo algo um tanto difícil de ser assimilado pelo jurista: afinal, como é possivel conceber um poder alheio ao direito ou, o que é pior, um poder (do qual o discurso jurídico nunca dera conta antes) que se incorpora e absorve o discurso jurídico? ",485.

Entretanto, se para Foucault a integração entre norma e vida é alcançada por meio do poder produtivo - mediante o sistema disciplina/normalizaçã $0^{486}$-, que se acopla à formulação da lei, de maneira que a lei mesma opera em virtude da norma ${ }^{487}$, para Agamben, a condição da soberania como limite da ordem jurídica significa que a exceção, que ambivalentemente fundamenta a soberania e a constituição do normal, é ela mesma o mecanismo pelo qual a vida é capturada pela lei.

De fato, enquanto Foucault entende ser necessária a especificação da operação de normalização como o mecanismo pelo qual a norma tutela a vida do corpo, esse instrumento não é requerido na teoria de Agamben: para este, a estrutura da exceção que baseia a lei é ela mesma o meio pelo qual vida é trazida à lei, uma vez que o estado de exceção permite uma imediata coincidência entre lei e vida.

É dizer, Foucault desenvolve uma crítica genealógica da integração e da mobilização da norma como uma forma particular de governar nas operações do poder, enquanto Agamben diagnostica uma crise normativa generalizada introduzida pela coincidência entre lei e vida. É o que passaremos a demonstrar.

Consabido, o pensamento de Foucault é, em parte, inspirado na fórmula de Georges Canguilhem, principalmente na obra $O$ Normal e o patológico. Nesse clássico estudo do

\footnotetext{
${ }^{485}$ In: Foucault, o direito e a "sociedade de normalização". In: Crítica da modernidade: diálogos com o direito. Organização de Ricardo Marcelo Fonseca. Florianópólis: Fundação Boiteux, 2005. p. 109.

486 “O que o século XVIII instaurou mediante o sistema de 'disciplina para a normalização', mediante o sistema de 'disciplina-normalização', parece-me ser um poder que, na verdade não é repressivo, mas produtivo - a repressão só figura a título de efeito colateral e secundário, em relação a mecanismos que, por sua vez, são centrais relativamente a esse poder, mecanismos que fabricam, mecanismos que criam, mecanismos que produzem". FOUCAULT, Michel. Os anormais: curso no Collège de France (19741975). Tradução de Eduardo Brandão. São Paulo: Martins Fontes, 2001, p. 64.

${ }^{487}$ Cf. Michel FOUCAULT. In: História da sexualidade I: vontade de saber. Tradução de Maria Thereza da Costa Albuquerque e J. A. Guilhon Albuquerque. 19. ed. Rio de Janeiro: Graal, 1988, p. 102.
} 
conceito de normal, CANGUILHEM propõe uma normatividade biológica ${ }^{488}$, quer dizer, “.... gostaríamos de saber como é que a normatividade essencial à consciência humana se explicaria se, de certo modo, já não estivesse, em germe, na vida" ${ }^{\text {"49. }}$.

Para esse pensador, a dialética interna do conceito de normal é expressa na polaridade fundamental da vida em relação ao ambiente em que o organismo se encontra. Nesse sentido, toda e qualquer variação ameaça a vida e, a depender da relação do organismo com o seu ambiente, ou haverá a constituição de uma patologia - ainda que essa patologia possa ser vista como algo inerente à esfera do norma ${ }^{490}$ - ou haverá a possibilidade de viver:

“... para um ser vivo, o fato de reagir por uma doença a uma lesão, a uma infestação, a uma anarquia funcional, traduz um fato fundamental: é que a vida não é indiferente. Às condições nas quais ela é possível, que a vida é polaridade e, por isso mesmo, posição inconsciente de valor, em resumo, que a vida é, de fato, uma atividade normativa., ${ }^{, 491}$

Assim, o anormal não existe fora da extensão da norma como tal, mas expressa uma possibilidade menos preferível - a depender do intérprete, porquanto, como visto, a perfeição pode ser entendida como anormal - em relação à norma própria. $\mathrm{O}$ anormal não significa uma permanente impossibilidade, mas indica que modos possíveis de viver são normativamente equivalentes.

Sem subestimar a importância do trabalho de Canguilhem na conceituação da normalização na obra de Foucault, é igualmente relevante reconhecermos sua guinada, uma vez que a preocupação de Foucault não reside tanto na elaboração de uma

\footnotetext{
488 "Ora, a vida está bem longe de uma tal indiferença em relação às condições que lhe são impostas; a vida é polaridade. O mais simples dos aparelhos biológicos de nutrição, de assimilação e de excreção traduz uma polaridade. Quando os dejetos da assimilação deixam de ser excretados por um organismo e obstruem ou envenenam o meio interno, tudo isso, com efeito, está de acordo com a lei (física, química, etc.), mas nada disso está de acordo com a norma, que é a atividade do próprio organismo. Esse é o fato simples que queremos designar quando falamos em normatividade biológica". CANGUILHEM, Georges. O normal e o patológico. Tradução de Maria Thereza Redig de Carvalho Barocas. 6 edição. Rio de Janeiro: Forense Universitária, 2009, p. 88.

${ }^{489}$ CANGUILHEM, Georges. Op. cit., p. 87.

490 "Sem dúvida, há uma maneira de considerar o patológico como normal, definindo o normal e o anormal pela frequência estatística relativa. Em certo sentido, pode-se dizer que uma saúde perfeita contínua é um fato anormal." CANGUILHEM, Georges. Op. cit., p. 96.

${ }^{491}$ CANGUILHEM, Georges. Op. cit., p. 86.
} 
normatividade interna na vida natural, ou na lei, mas nos caminhos pelos quais - o como as normas são elas mesmas impostas sobre o corpo vivente do sujeito e, subsequentemente, tomadas dentro desse corpo.

Ou seja, Canguilhem enfoca na elaboração de um conceito de vida que enfatiza a normatividade a ela interna. Em contraste, Foucault inicia com a presunção da efetividade regulatória do poder para descrever os modos de incorporação e corponificação da norma. Isto é, ao se tornarem embutidas nas relações de poder, as normas ganham uma certa força legal, e a normalização resulta num modo particular de institucionalização dessa força, conquanto não seja uma força necessariamente efetiva em seu embate para regularizar as forças do corpo, seja no nível do corpo individual, seja no nível da população ${ }^{492}$.

Torna-se agora compreensível porque podemos entender que Foucault foi consistentemente preocupado com o exame da fixação política das fronteiras do normal e do anormal por meio das operações da normalização. Dentro de uma sociedade normalizadora o aparato legal é cada vez mais incorporado na continuidade das instituições, cuja função é, em sua maioria, regulatória, de maneira que o modo pelo qual a lei opera é a norma. Isso claramente não significa que a lei é superada de todo, mas, como aparato legal, a lei continua a ser operada dentro do regime do biopoder, embora numa maneira distinta. De acordo com MÁRCIO AlveS DA FONSECA, “... uma vez abandonada a concepção estreita da lei como um sistema de comandos e proibições é que se estaria apto a descobrir, não uma separação ou uma distância entre normalização e lei, mas uma interpenetração entre ambas" ${ }^{493}$. Sob essas premissas Foucault adverte: “... o direito, é preciso examiná-lo, creio eu, não sob o aspecto de uma legitimidade a ser fixada, mas sob o aspecto dos procedimentos de sujeição que ele põe em prática". ${ }^{4}$

\footnotetext{
${ }^{492}$ Cf. Catherine MILLS. In: Biopolitics, liberal eugenics, and nihilism. In: CALARCO, Matthew; DECAROLI, Stevens (ed.). Giorgio Agamben: sovereignty and life. Stanford, California: Stanford University Press, 2007. p. 183.

${ }^{493}$ FONSECA, Márcio Alves da. Michel Foucault e o direito. Tese de doutorado apresentada à Faculdade de Direito da Universidade de São Paulo, 2001, acervo Dedalus, Tomo 32950/02, p. 141.

${ }^{494}$ Michel FOUCAULT. Em defesa da sociedade. São Paulo: Martins Fontes, 2002, p. 32.
} 
Ou seja, ao invés de operar por meio de um vínculo histórico com a soberania ${ }^{495}$, a lei agora opera, segundo o pensamento foucaultiano, de acordo com o confronto entre direito e disciplina ${ }^{496}$. Quer dizer, para Foucault, a legalidade não está mais intrinsecamente ligada à soberania, mas como elemento de complementaridade dos mecanismos de normalização. Com efeito, Foucault não se cansa de indicar a diferença essencial entre o poder normalizador e o poder jurídico-soberano, entre o poder da normalização e o poder do direito: "o discurso da disciplina é alheio ao da lei" ${ }^{\text {"497 }}$. Todavia, explica:

“... essa diversidade não implica no fato de que essas duas formas de poder não possam se entrelaçar, se implicar e se enredar, formando uma teia de dominação/sujeição complexa, cujos efeitos recaem não só sobre os limites da ação livre dos sujeitos (como quer fazer crer o princípio da legalidade vigente em todas as Constituições modernas) mas também incidem sobre os indivíduos e sobre as populações subjetivando-as e objetivando-as". ${ }^{498}$

De fato, não somente as normas se opõem à lei enquanto figura da soberania, como elas são o modo como a lei opera. Normas são a condição operacional da lei numa sociedade biopolítica, uma vez que é precisamente a norma que permite que a lei opere em conjunção a uma série de crescentes aparatos regulatórios, inclusive a medicina. As normas dão à lei acesso ao corpo num modo inédito, quer dizer, como uma força regulatória contínua ao invés de um violento instrumento da soberania.

Outro ponto de interesse quanto à norma na genealogia de Foucault é o papel que esta adquire na normalização da própria norma - a disciplina como colonizadora da

\footnotetext{
${ }^{495}$ Foucault insiste em “... uma nova mecânica do poder, que tem procedimentos bem particulares, instrumentos totalmente novos, uma aparelhagem muito diferente e que, acho eu, é absolutamente incompativel com as relações de soberania". In: Em defesa da sociedade. São Paulo: Martins Fontes, 2002, p. 41.

${ }^{496}$ Cf. Catherine MILLS. Biopolitics, liberal eugenics, and nihilism. In: CALARCO, Matthew; DECAROLI, Stevens (ed.). Giorgio Agamben: sovereignty and life. Stanford, California: Stanford University Press, 2007. p. 185.

${ }^{497}$ Cf. Michel FOUCAULT. In: Em defesa da sociedade. São Paulo: Martins Fontes, 2002, p. 45.

${ }^{498}$ FONSECA, Ricardo Marcelo. Foucault, o direito e a "sociedade de normalização". In: Crítica da modernidade: diálogos com o direito. Organização de Ricardo Marcelo Fonseca. Florianópólis: Fundação Boiteux, 2005, p. 123.
} 
norma ${ }^{499}$. Enquanto normalização é construída enquanto homogeneização, é importante notarmos que, para Foucault, a norma não opera simplesmente por meio da homogeneização da população (“constituição de 'quadros vivos' que transformam as multidões confusas, inúteis ou perigosas em multiplicidades organizadas" ${ }^{, 500}$ ) ou pela erradicação de diferenças num nível biológico ou anatômico. Ao contrário, como contraponto da normalização, infrações da norma são produzidas como um efeito da aplicação da norma, de modo que a particularidade de um indivíduo é identificada e calibrada somente por meio da operação da norma ${ }^{501}$.

Assim, Foucault argumenta que a normalização é simultaneamente totalizadora e individualizadora em sua operação; ela estabelece um padrão comum e também obriga aqueles colocados em relação com a norma a revelar suas próprias particularidades irredutíveis por meio da identificação de divergências individuais em relação ao padrão: assim, ela determina homogeneidade e diversidade. Isso significa, destarte, que é somente com base na aplicação da norma que o indivíduo emerge, e é nesse sentido que o indivíduo é simultaneamente um efeito e um veículo do biopoder.

Por outro lado, Agamben preocupa-se mais com a lei e com as condições de sua aplicação ou suspensão, ou seja, com a exceção ${ }^{502}$. Enquanto a concepção de Foucault quanto à integração da vida e da lei no biopoder mantém uma ambivalência direcionada ao papel do poder soberano dentro da emergência de uma sociedade normalizadora, amarrado a uma preocupação com a morte como poder sobre a vida, para Agamben é justamente a lógica da soberania que irremediavelmente vincula lei à vida.

Portanto, biopoder não resulta numa radical transformação da racionalidade do poder de um direito de morte para patrocinar a vida, mas, ao contrário, é simplesmente a clara manifestação da lógica da soberania no coração da ordem jurídico-política da democracia liberal. Com relevância, para Agamben, enquanto característica da forma de lei operativa no Ocidente moderno, a coincidência da vida e da lei também indica um niilismo

\footnotetext{
499 "Que em nossos dias o poder se exerça simultaneamente através deste direito e destas técnicas; que estas técnicas e estes discursos criados pelas disciplinas invadam o direito; que os procedimentos de normalização colonizem cada vez mais os da lei...”. FOUCAULT, Michel. Microfísica do poder. Tradução de Roberto Machado. Rio de Janeiro: Edições Graal, 1979, p. 190.

${ }^{500}$ Cf. Michel FOUCAULT. In: Vigiar e Punir: nascimento da prisão. Tradução de Raquel Ramalhete. 36 ed. Rio de Janeiro: Vozes, 2009, p. 143,

${ }^{501}$ Cf. Catherine MILLS. Op. cit., p. 187

${ }^{502}$ Cf. Catherine MILLS. Op. cit., p. 189.
} 
fundamental no coração da lei que, por sua vez, é indicativo de uma crise normativa. Isso se dá porque a coincidência entre lei e vida indica que a lei está vigente sem qualquer significado, esvaziada de todo conteúdo e autoridade regulatória além de uma violência nua.

A mais óbvia distinção entre Foucault e Agamben parece ser, assim, o tratamento da soberania: o biopoder é, no mínimo, tão antigo quanto a exceção soberana, e a produção de um corpo biopolítico é a atividade originária do poder soberano. Isso significa que o biopoder opera em conjunção ao poder soberano desde o início e que a política moderna não é determinada pela emancipação do biopoder, mas, na verdade, somente um trazer à luz desse nó secreto que une soberania e o biopoder na vida nua. Esse trazer à luz resulta justamente na realização do estado de exceção como a situação normal na política atual.

\subsubsection{A fundação da cidade moderna}

Como não poderia deixar de ser, Agamben adequará sua teoria aos fundamentos da própria cidade moderna, declinando abertamente que "É chegado, portanto, o momento de reler desde o princípio todo o mito de fundação da cidade moderna, de Hobbes a Rousseau.", 503

Partindo de exemplos como o wargus $^{504}$, o nem homem, nem fera (não/nem), friedlos ${ }^{505}$ e o bando ${ }^{506}$, e balizando-se na afirmação de que " $O$ estado de natureza

${ }^{503}$ AGAMBEN, Giorgio. Homo sacer: o poder soberano e a vida nua I. Tradução de Henrique Burigo. Belo Horizonte: Editora UFMG, 2002, p. 115.

${ }^{504}$ Wargus, o homem-lobo. Agamben esclarece: "A transformação em lobisomem corresponde perfeitamente ao estado de exceção, por toda a duração do qual (necessariamente limitada) a cidade se dissolve, e os homens entram em uma zona de indistinção com as feras." AGAMBEN, Giorgio. Homo sacer: o poder soberano e a vida nua I. Tradução de Henrique Burigo. Belo Horizonte: Editora UFMG, 2002, p. 114.

${ }^{505}$ Friedlos, o sem paz do antigo direito germânico que podia ser morto por qualquer um sem que se cometesse suicídio, segundo a "doutrina da Friedlosigkeit elaborada por volta da metade do século XIX pelo germanista Wilda." AGAMBEN, Giorgio. Homo sacer: o poder soberano e a vida nua I. Tradução de Henrique Burigo. Belo Horizonte: Editora UFMG, 2002, p. 111.

506 "Até mesmo o bando medieval apresenta características análogas: o bandido podia ser morto (bannire idem est quod dicere quilibet possit eum offendere: Cavalca, 1978, p.42) ou era até mesmo considerado já morto (exbannitus ad mortem de sua civitate debet haberi pro mortuo: Ibidem. P. 50). Fontes germânicas e anglo-saxônicas sublinham esta condição limite do bandido definindo-o como homem-lobo (wargus, werwolf, lat. garulphus, donde o francês loup garou, lobisomem): assim a lei sálica e a lei ripuária usam a fórmula wargus sit, hoc est expulsus em um sentido que recorda o sacer esto que sancionava a matabilidade do homem sacro, e as leis de Eduardo o Confessor (1130-1135) definem o bandido wulfesheud (literalmente: cabeça de lobo) e o assemelham a um lobisomem (lupinum enim gerit caput a die utlagationis suae, quod ab anglis wulfesheud vocatur). Aquilo que deveria permanecer no inconsciente coletivo como um híbrido monstro entre humano e ferino, dividido entre a selva e a cidade - o lobisomem - é, portanto, na origem a 
hobbesiano não é uma condição pré-jurídica totalmente indiferente ao direito da cidade,

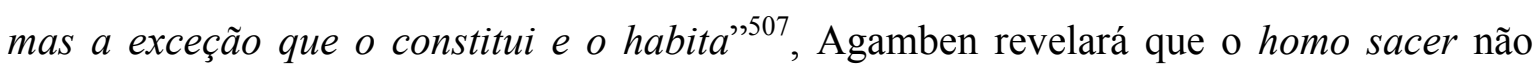
nasceu no solo de uma ordem jurídica constituída, mas de um período de vida pré-social indistinguível do âmago da própria cidade moderna. Isto é, Agamben esforça-se para adequar o estado de natureza hobbesiano ao seu próprio estado de exceção, até mesmo porque para ele mais originário que o vínculo da norma positiva ou do pacto social é o vínculo soberano:

"É somente sob esta luz que o mitologema hobbesiano do estado de natureza adquire seu sentido próprio. Como vimos que o estado de natureza não é uma época real, cronologicamente anterior à fundação da Cidade, mas um princípio interno desta, que aparece no momento em que se considera a Cidade tanquam dissoluta (portanto, algo como um estado de exceção), assim, quando Hobbes funda a soberania através da remissão homo homini lupus, no lobo é necessário saber distinguir um eco do wargus e do caput lupinum das leis de Eduardo o Confessor: não simplesmente besta fera e vida natural, mas, sobretudo zona de indistinção entre humano e ferino, lobisomem, homem que se transforma em lobo e lobo que torna-se homem: vale dizer, banido, homo sacer." ${ }^{, 508}$

Com essas ponderações, Agamben será capaz de cunhar a teoria de que a fundação do Estado moderno deve se livrar de todas e quaisquer representações do ato político originário como um contrato ou uma convenção - notadamente fundamentado no conceito de liberdade-necessidade hobbesiano ${ }^{509}$-, inclusive John Locke, portanto, declarando a teoria hobessiana não mais que um "mal-entendido",510. É dizer, o que Agamben denomina político, Hobbes chama de estado de natureza ${ }^{511}$. Agamben realmente faz uma releitura de Hobbes - até então inédita, parece-nos - para declarar que a relação entre o estado de

figura daquele que foi banido da comunidade". AGAMBEN, Giorgio. Homo sacer: o poder soberano e a vida nua I. Tradução de Henrique Burigo. Belo Horizonte: Editora UFMG, 2002, p. 111.

${ }^{507}$ AGAMBEN, Giorgio. Homo sacer: o poder soberano e a vida nua I. Tradução de Henrique Burigo. Belo Horizonte: Editora UFMG, 2002, p. 112.

${ }^{508}$ AGAMBEN, Giorgio. Homo sacer: o poder soberano e a vida nua I. Tradução de Henrique Burigo. Belo Horizonte: Editora UFMG, 2002, p. 112.

${ }^{509}$ Cf. Thomas HOBBES. In: Leviathan: ou a matéria, forma e poder de um estado eclesiástico civil. 2. ed. Tradução de Rosina D’Angina. São Paulo: Ícone Ed., 2003, p. 155.

${ }^{510}$ AGAMBEN, Giorgio. Homo sacer: o poder soberano e a vida nua I. Tradução de Henrique Burigo. Belo Horizonte: Editora UFMG, 2002, p. 115-116.

${ }^{511}$ Cf. William Rasch. Op. cit., p 101. 
natureza e o commonwealth não deve ser compreendida em termos de dentro e fora, anterior ou posterior, mas de potencialidade:

"É importante notar, de fato, que, em Hobbes, o estado de natureza sobrevive na pessoa do soberano, que é o único a conservar o seu natural ius contra omnes. A soberania se apresenta, então, como um englobamento do estado de natureza na sociedade, ou, se quisermos, como um limiar de indiferença entre natureza e cultura, entre violência e lei, e esta própria indistinção constitui a específica violência soberana. O estado de natureza não é, portanto, verdadeiramente externo ao nómos, mas contém sua virtualidade. ${ }^{, 12}$

Em outras palavras, a identidade hobbesiana entre violência e homo hominis lupus pressupõe em Agamben uma indistinção entre violência e direito, até mesmo porque o estado de natureza não deve ser considerado necessariamente um espaço-temporal - ou uma condição pré-jurídica, assim como o estado de exceção -, mas sim um princípio interno ao Estado que se revela na exceção:

"Estado de natureza e estado de exceção são apenas as duas faces de um único processo topológico no qual, como numa fita de Moebius ou em uma garrafa de Leyden, o que era pressuposto como externo (o estado de natureza) ressurge agora no interior (como estado de exceção), e o poder soberano é justamente esta impossibilidade de discernir externo e interno, natureza e exceção, phýsis e nómos. ${ }^{513}$

Assim, "não existem, primeiro, a vida como dado biológico natural e a anomia como estado de natureza e, depois, sua implicação no direito por meio do estado de exceção. Ao contrário, a própria possibilidade de distinguir entre vida e direito, anomia e nomos coincide com sua articulação na máquina biopolítica. A vida pura e simples é um produto da máquina e não algo que preexiste a ela, assim como o direito não tem nenhum

\footnotetext{
${ }^{512}$ AGAMBEN, Giorgio. Homo sacer: o poder soberano e a vida nua I. Tradução de Henrique Burigo. Belo Horizonte: Editora UFMG, 2002, p. 41-42.

${ }_{513}$ AGAMBEN, Giorgio. Homo sacer: o poder soberano e a vida nua I. Tradução de Henrique Burigo. Belo Horizonte: Editora UFMG, 2002, p. 43.
} 
fundamento na natureza ou no espírito divino" ${ }^{, 514}$. O estado de natureza nesse sentido não é um estado de guerra de todos contra todos, mas uma condição em que cada um é para o outro vida nua e homo sacer. WILLIAM RASCH delineia muito bem essa simbiose:

"In the Hobbesian state of nature, each person has the same right, the right to self-preservation, thus each person has the same absolute power over the other - and, of course, each person is also subject to the same absolute power of the other. The condition of the human individual in the state of nature is the condition of war. In this war of all against all, nothing is unjust because there is no law, no distinction between good and evil, right and wrong, justice and unjustice. The state of nature, it could therefore be argued, is the state in which 'life may be killed but not sacrificed', indeed, the sphere in which the roles of sovereignty and homo sacer are forever interchangeable." 515

De conseguinte, “... em Hobbes, o fundamento do poder soberano não deve ser buscado na cessão livre, da parte dos súditos, do seu direito natural, mas, sobretudo, na conservação, da parte do soberano, de seu direito natural de fazer qualquer coisa em relação a qualquer um..." ${ }^{, 16}$. Assim, a violência soberana não é fundada sobre um pacto ${ }^{517}$, mas sobre a exclusão inclusiva da vida nua no Estado. O estado de natureza é, na verdade, um estado de exceção, cuja fundação não pode ser encontrada num momento temporal, pois continuamente operante no estado civil na forma de decisão soberana. Algo que, exemplificativamente, “... está ocorrendo na ex-Ioguslávia e, mais em geral, na Euorpa oriental não devem ser vistos como um reemergir do estado natural de luta de todos contra todos, que prenuncia a constituição de novos pactos sociais e de novas localizações nacional-estatais, mas, antes, como o aflorar à luz do estado de exceção como estrutura permanente de des-localização e des-locaçao jurídico-política"518. É nesse sentido que STEVEN DeCAROLI explicita que:

514 AGAMBEN, Giorgio. Estado de exceção. Tradução de Iraci D. Poleti. São Paulo: Boitempo, 2004, p. 132.

${ }^{515}$ RASCH, William. Op. cit., p. 101.

516 AGAMBEN, Giorgio. Homo sacer: o poder soberano e a vida nua I. Tradução de Henrique Burigo. Belo Horizonte: Editora UFMG, 2002, p. 113.

${ }^{517}$ Foucault parece concordar que um corpo social não pode ser constituído pela universalidade de vontades: "Ora, não é o consenso que faz surgir o corpo social, mas a materialidade do poder se exercendo sobre o próprio corpo dos indivíduos". In: Microfísica do poder. Tradução de Roberto Machado. Rio de Janeiro: Edições Graal, 1979, p. 146.

518 AGAMBEN, Giorgio. Homo sacer: o poder soberano e a vida nua I. Tradução de Henrique Burigo. Belo Horizonte: Editora UFMG, 2002, p. 44. 
'Not unlike Hobbes's 'state of nature', the camp represents extreme potentiality, the thoroughly unconditioned. However, unlike the state of nature, the camp is not completely without relation to the law, for it is the law - or more accurately, sovereign authority - that brings the camp into being, and it is in relation to the law that the camp is rendered exceptional. ${ }^{, 519}$

Comentando a relação entre autoridade e território, STEVEn DeCAROLI parece concordar com Agamben no sentido de que: "The conventional image of the sovereign ruler standing outside the law, perched above it, must therefore be dismissed as an inadequate political myth that preserves a misconceived Hobbesian political ontology. Only by abandoning this notion of the sovereign set outside the law, only if we categorically refuse to pose the question of power from the vantage of the state, can we begin to grasp the complexities of biopolitics" ${ }^{250}$.

Assim, “... são os corpos absolutamente matáveis dos súditos [corpos do Leviatã] que formam o novo corpo biopolítico do Ocidente" ${ }^{21}$. O homem lobo do homem habita estavelmente na cidade. Como explicitado no início desta dissertação, é sobre a exclusão inclusiva da vida nua que se funda a cidade dos homens ${ }^{522}$.

\subsubsection{Poder constituinte e o estado de exceção}

A temática do poder constituinte tem sido objeto de reflexão por parte de cientistas políticos, juristas e sociólogos desde sua concepção - associada à concepção de constituição escrita - esboçada na prática constituinte estadunidense e elaborada por Sieyès no século XVIII, no curso da Revolução Francesa. Não raramente, o paradoxo da soberania é resolvido, mas não solucionado, por meio da distinção entre poder constituinte e poder constituído, uma distinção que Schmitt endossa ${ }^{523}$ na teorificação das ditaduras soberana e comissária, por exemplo. Para Schmitt, o povo está acima e além da constituição,

\footnotetext{
${ }^{519}$ DECAROLI, Steven. Op. cit., p. 52.

${ }^{520}$ DECAROLI, Steven. Op. cit., p. 49.

${ }^{521}$ AGAMBEN, Giorgio. Homo sacer: o poder soberano e a vida nua I. Tradução de Henrique Burigo. Belo Horizonte: Editora UFMG, 2002, p. 131.

${ }^{522}$ Cf. Giorgio AGAMBEN. In: Homo sacer: o poder soberano e a vida nua I. Tradução de Henrique Burigo. Belo Horizonte: Editora UFMG, 2002, p. 15.

${ }^{523}$ Cf. William RASCH. Op. cit., 97.
} 
entendendo, portanto, que o poder constituinte, como unidade política, não se esgota no ato constituído, mas permanece existindo acima e a seu lado ${ }^{524}$. Em suas palavras, o poder constituinte “... no es susceptible de traspaso, enajenación, absorción o consunción. Le queda siempre la posibilidad de seguir existiendo, y se encuentra al mismo tiempo y por cima de toda Constitución, derivada de el...",525

Como não poderia deixar de ser, Agamben traz uma relevante compreensão do tema como parte da indeterminação topológica que caracteriza a integralidade de sua teoria política, até mesmo porque, em Potenza e diritto, um dos principais capítulos de Homo sacer, Agamben declara que “... Talvez em nenhuma parte o paradoxo da soberania se mostre tão à luz como no problema do poder constituinte e de sua relação com o poder constituído",526.

Partindo de Georges Burdeau, que construiu uma teoria completa do Estado ${ }^{527}$, e os princípios de Benjamin acima expostos, Agamben descreve que poder constituinte e poder constituído não podem existir em dois planos, refutando a tese pela qual o poder constituinte não se esgota num poder constituído, citando aqui o conceito trotskista de revolução permanente e o conceito maoísta de revolução ininterrupta, e, paralelamente, recusando a tese pela qual se distinguem teoricamente poder constituinte e poder soberano. Outrossim, para Agamben, tanto a tese reivindicadora do "caráter irredutível e originário do poder constituinte, que não pode ser de modo algum condicionado e constrangido", assim como a tese contrária, que "desejaria reduzir o poder constituinte ao poder de revisão previsto na constituição” ficam aprisionadas no paradoxo da soberania: “... ainda que o poder constituinte, como violência que põe o direito, seja certamente mais nobre que a violência que o conserva, ele não possui, porém, em si nenhum título que possa legitimar

${ }^{524}$ Cf. BERCOVICI, Gilberto. In: Soberania e constituição: para uma crítica do constitucionalismo. São Paulo: Quartier Latin, 2008, p. 26.

${ }^{525}$ SCHMITT, Carl. Teoría de la Constitución. Tradução de Francisco Ayala. Madrid: Alianza Editorial, 1982, p. 108.

${ }^{526}$ AGAMBEN, Giorgio. Homo sacer: o poder soberano e a vida nua I. Tradução de Henrique Burigo. Belo Horizonte: Editora UFMG, 2002, p. 47.

${ }^{527}$ Quanto ao poder constituinte, que é de fato uma parcela de seu trabalho, Burdeau entende que é por ele que o soberano designa os órgãos do Estado capazes de agir, limitando, assim, o papel dos governantes. É dizer, o soberano é aquele que dá força válida para que, construindo sua vontade por meio de condições espirituais, econômicas e históricas (meio social), nasça uma comunidade jurídica independente de outras para realizar a idéia de direito. A frase inaugural de $O$ Estado, segundo a qual "Nem toda sociedade politicamente organizada é um Estado. Portanto, não podemos considerar válidas as definições que o assimilam ao fato da diferenciação entre governantes e governados. O que essa hierarquia revela é a existência de um Poder", confirma essa assertiva. BURDEAU, Georges. O Estado. Tradução de Maria Ermantina de Almeida Prado Galvão. São Paulo: Martins Fontes, 2005, p. 1. 
a sua alteridade, e mantém, aliás, com o poder constituído um relacionamento ambiguo e insuprimivel $^{, 528}$.

Objetivando uma solução ao problema, Agamben retomará sua doutrina da indiscernibilidade no sentido de que "Como o poder soberano se pressupõe como estado de natureza, que é assim mantido em relação de bando com o estado de direito, assim ele se divide em poder constituinte e poder constituido e se conserva em relacionamento com ambos, situando-se em seu ponto de indiferença" ${ }^{429}$. Nas palavras de LELAND DE LA DURANTAYE, Agamben vincula a relação entre poder constituinte e poder constituído à relação entre potencialidade e ato, acoplando-os à própria soberania:

“... the sovereign retains this potential to suspend the rule of law even when not doing so, just as we might say that in the stabilized form of constituted power the state retains the potentiality for exercising its full power to suspend the rule of law." 530

Isto é, Agamben equaciona poder constituinte e poder soberano, uma vez que não haveria critério ou momento que permitisse distingui-los, de modo que se confundem numa potencialidade. Ou seja, poder constituinte não é um momento da expressão do poder soberano, como entende NELSON SALDANHA ${ }^{531}$, exemplificativamente; o poder soberano é essencialmente co-igual ao poder constituinte ao passo que nenhum deles pode ser determinado pela ordem existente e nenhum deles pode ser limitado à constituição dessa ordem:

"Mas se, como acontece (segundo o próprio Schmitt) já a partir de Sieyès, o poder constituinte se identifica com a vontade constituinte do povo ou da nação, então não está claro o critério que permite distingui-lo da soberania

\footnotetext{
${ }^{528}$ AGAMBEN, Giorgio. Homo sacer: o poder soberano e a vida nua I. Tradução de Henrique Burigo. Belo Horizonte: Editora UFMG, 2002, p. 47-48.

${ }^{529}$ AGAMBEN, Giorgio. Homo sacer: o poder soberano e a vida nua I. Tradução de Henrique Burigo. Belo Horizonte: Editora UFMG, 2002, p. 48.

${ }_{530}$ Leland de la DURANTAYE. Op. cit., p. 232.

531 "Admitida a soberania como expressão genérica e unitária das forças do Estado, o poder constituinte aparece como uma manifestação ou um momento dessa expressão, justamente o momento que sistematicamente preexiste, como origem, a todos os outros". SALDANHA, Nelson. O poder constituinte. São Paulo: Revista dos Tribunais, 1986, p. 67.
} 
popular ou nacional, e sujeito constituinte e sujeito soberano tendem a confundir-se.",532

Isso porque a função primária da soberania não é o estabelecimento da lei enquanto sujeito constituinte, mas a determinação do que excede a lei, de maneira que o estado de exceção é mais fundamental à soberania do que a própria lei. Isto é, por meio do estabelecimento do limite entre legal e do não-legal, a exceção produz os dois ${ }^{533}$.

Outrossim, Agamben reivindica, explicitamente politizando o problema da potencialidade, que “... a relação entre poder constituinte e poder constituído é tão complexa quanto a que Aristóteles instituiu entre potência e ato, dýnamis e enérgeia", quer dizer, a existência autônoma da potencialidade ${ }^{534}$. Como dito acima, a potência se mantém em relação ao ato na forma de sua suspensão, ou seja, ela pode o ato podendo não realizálo, pode soberanamente a própria impotência. Mutatis mutandis, assim como a potência se transfere ao ato na deposição - entenda-se realização - de sua impotência, a soberania é justamente aquele ato constituído que se realiza simplesmente deixando-se ser, é dizer, depondo a própria potência de não ser. Potência e ato, constituinte e constituído, “... não são mais que dois aspectos do processo de autofundação soberana do ser" ${ }^{\natural 535}$; no limite, potência e ato são indiscerníveis e essa zona de indistinção é o soberano.

Mas esse ponto diverge do pensamento de outro teórico italiano, Antonio Negri, que se posiciona contra a separação da potencialidade e ato que Agamben enfatiza e, portanto, a autonomia da potencialidade. Em sua obra, Negri endereça a diferença entre poder constituinte e poder constituído - em que, como discorrem GIUSEPPE COCCO e ADRIANO PILATTI, "a potência do trabalho vivo é o poder constituinte e que o trabalho constitutivo da potência jamais poderá ser definitivamente controlado ou absorvido pelo poder constituído do trabalho morto"536 - para arguir que poder constituinte não pode ser

\footnotetext{
${ }^{532}$ AGAMBEN, Giorgio. Homo sacer: o poder soberano e a vida nua I. Tradução de Henrique Burigo. Belo Horizonte: Editora UFMG, 2002, p. 50.

${ }^{533}$ Cf. Steven DECAROLI. Op. cit., p. 54.

${ }^{534}$ AGAMBEN, Giorgio. Homo sacer: o poder soberano e a vida nua I. Tradução de Henrique Burigo. Belo Horizonte: Editora UFMG, 2002, p. 52.

${ }^{535}$ AGAMBEN, Giorgio. Homo sacer: o poder soberano e a vida nua I. Tradução de Henrique Burigo. Belo Horizonte: Editora UFMG, 2002, p. 54.

${ }^{536}$ COCCO, Giuseppe; PILATTI, Adriano. Desejo e libertação: a potência constituinte da multidão. In: NEGRI, Antonio. Poder Constituinte: ensaio sobre as alternativas da modernidade. Tradução de Adriano Pilatti. Rio de Janeiro, DP\&A, 2002, p. vii.
} 
equacionado com a soberania. Isso porque, enquanto o poder constituinte é um ato livre de criação que não se exaure no objeto criado, soberania limita, reduz e fixa o poder constituinte. Para NEGRI, toda determinação do poder constituinte é livre e permanece livre, enquanto o poder soberano apresenta o término e a exaustão do trabalho do poder constituinte, quer dizer, um esgotamento do poder constituinte:

\begin{abstract}
"Quando o poder constituinte desencadeia o processo constituinte, toda determinação é liberada e permanece livre. A soberania, ao contrário, apresenta-se como fixação do poder constituinte, como termo deste, como esgotamento da liberdade de que ele é portador: oboedientia facit auctoritatem.",537
\end{abstract}

De acordo com Negri, enveredando-se por Maquiavel, Espinosa e Marx, poder constituinte é um sujeito, uma subjetividade coletiva numa ordem mundial, a multidão (multitudo), de maneira que o político é por definição uma força ontológica de multidão. É nesse sentido que, ao criticar Agamben, ANTONIO NEGRI dirá que "A questo punto, è evidente che non c'è differenza tra stato di eccezione e potenza costituente, perché entrambi vivono sullo stesso livello di indistinzione "538. De acordo com Negri e seu colaborador de longa data, Michael Hardt ${ }^{539}$, em Império, o erro de Agamben é a construção da vida nua como fundamentalmente passiva em relação à violência soberana, singularmente exposta sem recurso ou resposta ${ }^{540}$. Para eles, o pensamento de Agamben quanto à vida nua simplesmente expõe "por trás dos abismos políticos que o totalitarismo moderno construiu as condições (mais ou menos heróicas) de passividade humana". Em contraste, NEGRI e HARDT reivindicam que o nazismo ${ }^{541}$ e o fascismo "tentaram em vão destruir o enorme poder em que a vida sem disfarces poderia se transformar e eliminar

\footnotetext{
${ }^{537}$ NEGRI, Antonio. Poder constituinte: ensaio sobre as alternativas da modernidade. Tradução de Adriano Pilatti. Rio de Janeiro, DP\&A, 2002, p. 37.

538 NEGRI, Antonio. Il frutto maturo della redenzione. Disponível em http://www.generationonline.org/t/negriagamben.htm. Acessado em 5.8.2009.

${ }^{539}$ Michel Hardt é, aliás, o tradutor de à língua inglesa de La comunità che viene.

${ }^{540}$ Cf.Catherine MILLS. In: The philosophy of Agamben. McGill-Queen's University Press, 2008, p. 75.

${ }^{541}$ Negri assim define a relação entre totalitarismo e poder constituinte: “... existe totalitarismo quando o enigma do poder constituinte não é revelado, quando sua efetividade potente é negada ou mistificada no poder constituído, quando sua radicalidade de potência metafísica e de desejo (cupiditas) coletivo é refutada. Então, na ausência de desejo, o político torna-se totalidade disciplinar, totalitarismo". In: Poder Constituinte: ensaio sobre as alternativas da modernidade. Tradução de Adriano Pilatti. Rio de Janeiro, DP\&A, 2002, p. 48 .
} 
toda forma pela qual os novos poderes de cooperação produtiva da multidão são acumulados",542.

Agamben, por seu turno, nega a tentativa de Negri separar poder constituinte e poder soberano ao dizer que:

“O problema da distinção entre poder constituinte e poder soberano é, certamente, essencial; mas que o poder constituinte não promane da ordem constituída nem se limite a instituí-la, e que ele seja, por outro lado, praxe livre, não significa ainda nada quanto à sua alteridade em relação ao poder soberano. Se a nossa análise de estrutura original da soberania como bando e abandono é exata, estes atributos pertencem, de fato, também ao poder soberano, e Negri, na sua ampla análise da fenomenologia histórica do poder constituinte, não pode encontrar em parte alguma o critério que permite isolá-lo do poder soberano." 543

Por oportuno, se por um lado Agamben refuta a tese de Negri e a tentativa deste de afastar poder constituinte da soberania, ele revela que o interessante da obra desse autor é exatamente a assertiva de que o poder constituinte não deve se mostrar como um conceito político, mas como uma categoria da ontologia, muito embora focada no ato em sua relação com a potência, e não na potência enquanto figura autônoma, porquanto “... no momento em que a potência se institucionaliza, ela deixa de ser potência, declara jamais tê-lo sido... Que a potência, ao se institucionalizar, não possa senão negar a si mesma, parece-nos uma primeira afirmação relevante e irredutivel ${ }^{\text {"544. }}$

"O interesse do livro de Negri reside, sobretudo, na perspectiva última que... o poder constituinte, uma vez pensado em toda a sua radicalidade, cesse de ser um conceito político em sentido estrito e se apresente necessariamente como uma categoria da ontologia... O problema se desloca, assim, da filosofia política à filosofia primeira (ou, se quisermos, a política é restituída à sua

\footnotetext{
${ }^{542}$ HARDT Michael; NEGRI, Antonio. Império. Tradução de Berilo Vargas. 8. ed. Rio de Janeiro: Record, 2006, p. 388.

${ }_{543}$ AGAMBEN, Giorgio. Homo sacer: o poder soberano e a vida nua I. Tradução de Henrique Burigo. Belo Horizonte: Editora UFMG, 2002, p. 51.

${ }^{544}$ NEGRI, Antonio. Poder constituinte: ensaio sobre as alternativas da modernidade. Tradução de Adriano Pilatti. Rio de Janeiro, DP\&A, 2002, p. 37.
} 
condição ontológica). Somente uma conjunção inteiramente nova de possibilidade e realidade, de contingência e necessidade e dos outros páthe tôu óntos, poderá, de fato, permitir que se fenda o nó que une soberania e poder constituinte: e somente se conseguirmos pensar de modo diverso a relaçao entre potência e ato, e, aliás, além dela, será possível conceber um poder constituinte inteiramente livre do bando soberano." ${ }^{545}$

GILBERTO BERCOVICI corrobora que "Para Antonio Negri, o poder constituinte é ontológico, um produto da descontinuidade radical, não podendo ser vinculado à soberania, que é o seu oposto. A soberania é poder constituido, que busca bloquear e

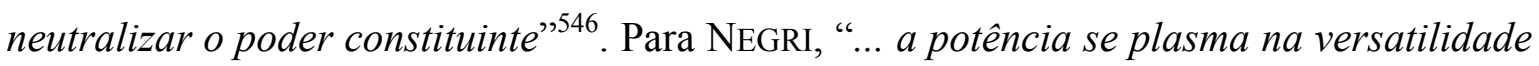
da multidão ${ }^{, 547}$, é dizer, o poder constituinte não vem depois da política em seu entender, até mesmo porque política é a “... potência ontológica de uma multidão de singularidades cooperantes" 548 .

De qualquer forma, é assim que, nessa zona de indeterminação, quaisquer distinções entre poder constituinte e poder constituído não fazem sentido à luz de uma verdadeira ação política agambeniana:

"Mostrar o direito em sua não-relação com a vida e a vida em sua não-relação com o direito significa abrir entre eles um espaço para a ação humana que, há algum tempo, reivindicava para si o nome 'política'. A política sofreu um eclipse duradouro porque foi contaminada pelo direito, concebendo-se a si mesma, no melhor dos casos, como poder constituinte (isto é, violência que põe o direito), quando não se reduz simplesmente a poder de negociar com o direito. Ao contrário, verdadeiramente política é apenas aquela ação que corta o nexo entre violência e direito., ${ }^{549}$

\footnotetext{
${ }^{545}$ AGAMBEN, Giorgio. Homo sacer: o poder soberano e a vida nua I. Tradução de Henrique Burigo. Belo Horizonte: Editora UFMG, 2002, p. 51.

${ }^{546}$ BERCOVICI, Gilberto. Soberania e constituição: para uma crítica do constitucionalismo. São Paulo: Quartier Latin, 2008, p. 34.

${ }^{547}$ NEGRI, Antonio. Poder constituinte: ensaio sobre as alternativas da modernidade. Tradução de Adriano Pilatti. Rio de Janeiro, DP\&A, 2002, p. 428.

${ }^{548}$ NEGRI, Antonio. Poder constituinte: ensaio sobre as alternativas da modernidade. Tradução de Adriano Pilatti. Rio de Janeiro, DP\&A, 2002, p. 457.

${ }^{449}$ AGAMBEN, Giorgio. Estado de exceção. Tradução de Iraci D. Poleti. São Paulo: Boitempo, 2004, p. 133.
} 
Para Agamben, “... por isto é tão árduo pensar uma 'constituição da potência' integralmente emancipada do princípio da soberania e um poder constituinte que tenha definitivamente rompido o bando que a liga ao poder constituído" ${ }^{\text {"50 }}$. É nessa vertente que Agamben defenderá, como veremos abaixo, a desativação de conceitos como soberania e poder constituinte, que estão hoje no núcleo de nossa tradição política ${ }^{551}$.

\subsection{A RELAÇÃo de ABANDONo}

Dissemos diversas vezes que a esclusione inclusiva nomeia a relação entre o político e o jurídico. De que se trata então essa relação também denominada a-bando-no? Seguindo a proposta de Jean-Luc Nancy, Agamben sugere que o termo mais apropriado para a potencialidade de a lei ser aplicada não mais se aplicando é o bando: “... chamemos bando (do antigo termo germânico que designa tanto a exclusão da comunidade quanto o comando e a insígnia do soberano), a esta potência (no sentido próprio da dýnamis aristotélica, que é sempre também dýnamis me energeîn, potência de não passar ao ato) da lei de manter-se na própria privação, de aplicar-se desaplicando-se ${ }^{\natural 552}$.

Isto é, a relação de exceção é uma relação de bando, em que aquilo que é excluído não é simplesmente colocado fora da lei e tornado irrelevante a ela, mas sim abandonado por ela:

“... Aquele que foi banido não é, na verdade, simplesmente posto fora da lei e indiferente a esta, mas é abandonado por ela, ou seja, exposto e colocado em risco no limiar em que vida e direito, externo e interno, se confundem. Dele não é literalmente possível dizer que esteja fora ou dentro do ordenamento (por isto, em sua origem, in bando, a bandono significam em italiano tanto 'à mercê de' quanto 'a seu talante, livremente', como na expressão correre a bandono, e bandito quer dizer tanto 'excluído, posto de lado' quanto 'aberto a todos, livre', como em mesa bandita e a redina bandita). É neste sentido que o paradoxo da

\footnotetext{
${ }^{550}$ AGAMBEN, Giorgio. Homo sacer: o poder soberano e a vida nua I. Tradução de Henrique Burigo. Belo Horizonte: Editora UFMG, 2002, p. 54.

${ }^{551}$ Cf. Giorgio AGAMBEN. Means without end: notes on politics. Traducão Vincenzo Binetti e Cesare Casarino. Minneapólis: University of Minnesota Press, 2000, p. 112.

${ }^{552}$ AGAMBEN, Giorgio. Homo sacer: o poder soberano e a vida nua I. Tradução de Henrique Burigo. Belo Horizonte: Editora UFMG, 2002, p. 36.
} 
soberania pode assumir a forma: 'não existe um fora da lei'. A relação originária da lei com a vida não é a aplicação, mas o Abandono."

$\mathrm{O}$ que foi posto em bando é remetido à própria separação e, simultaneamente, entregue à mercê de quem o abandona, ou seja, ao mesmo tempo excluso e incluso, dispensado e capturado. Como CATHERINE Mills define, citando Nancy: “... as Nancy states, 'the origin of 'abandonment' is a putting at bandon, where [b]andon is an order, a prescription, a decree, a permission and the power that holds these freely at its disposal. To abandon is to remit, entrust, or turn over to such a sovereign power, and to remit, entrust, or turn over to its ban, that is, to its proclaiming, to its convening, and to its sentencing... the law of abandonment requires that the law be applied through its withdrawal... Abandoned being finds itself deserted to the degree that it finds itself remitted, entrusted, or throuwn to this law"

Assim como a exceção que é incluída somente por meio de sua exclusão, o sujeito do banimento não é simplesmente excluído da abrangência da lei, colocado de lado ou intocável por ela, mas é conferido à lei por meio de sua remoção. Essa correlação entre exceção e o abandono significa que é impossível dizermos claramente se aquilo que foi banido está dentro ou fora da ordem jurídica (não/nem).

E, para entendermos a sentença de banimento e sua relação com a soberania, é necessária uma breve análise de alguns aspectos das doutrinas grega e romana, porquanto, segundo Agamben, somente ao compreendermos o uso que Aristóteles dá a ela em Politica, assim como o conceito de persona na lei romana, o banimento se torna mais claro.

A prática do banimento é antiga. Menção ao banimento como meio de punição remonta ao Código de Hamurabi, onde é inscrito contra o incesto, em sua linha 154: "Se alguém conhece a própria filha, deverá ser expulso da terra" ${ }^{\text {"55 }}$. Já na Grécia, é no Livro III de Política que Aristóteles trata do banimento como um remédio aceitável não para ações que ameacem a paz da pólis por meio de ações criminais ou violência, mas para

553 AGAMBEN, Giorgio. Homo sacer: o poder soberano e a vida nua I. Tradução de Henrique Burigo. Belo Horizonte: Editora UFMG, 2002, p. 36.

${ }_{554}$ MILLS, Catherine. The philosophy of Agamben. McGill-Queen's University Press, 2008, p. 62-63.

${ }^{555}$ Disponível em http://www.culturabrasil.pro.br/hamurabi.htm. 
modos de ser que não violem de qualquer modo a lei. Aristóteles discorre sobre o banimento no contexto de uma curiosa dificuldade político-jurídica: como a pólis deve tratar as ameaças legais à sua estabilidade, quer dizer, como tutelar uma ação que a ameaça a ordem precisamente aderindo às leis e aos maiorais ideais de sua comunidade?

No contrapeso à dificuldade de legislar contra aquilo que, de um lado, é veementemente obediente à lei e, de outro lado, "in virtue of being the way it is",556, turbulenta a estabilidade daquela lei, Aristóteles levanta o sujeito do ostraciscmo. Ou seja, quando do aparecimento de pessoas cujas virtudes são tão elevadas a ponto de não "serem comparáveis... ele ou ela já não podem ser tidos como membros quaisquer da cidade", o Estado literalmente se afasta deles, condenando “... ao exílio homens tidos como excessivamente poderosos por sua riqueza, ou popularidade, ou alguma outra forma de força política, banindo-os da cidade por tempo determinado" ${ }^{, 557}$.

Equacionando a cidade a um navio em alto mar e os cidadãos a marinheiros, Aristóteles dirá que “... embora cada marinheiro tenha funções diferentes (um é remador, outro é timoneiro, outro é vigia de proa e outros têm igualmente outras designações especiais)... a segurança da navegação é a preocupação de todos eles" "558, de maneira que cidadãos excepcionalmente proeminentes devem ser ostracizados em prol de uma "justiça política $^{, 559}$.

Consequentemente, não são aqueles que violam a lei que são ostracizados da pólis, mas aqueles que manejam a influência política, aqueles que predominam demais, direta ou indiretamente: ostracismo não é empregado contra aqueles que violam a lei, mas contra aqueles que, por meio de influência social ou monetária, ameaçam alterar a própria ordem política. Destarte, mesmo quando nenhuma conduta criminal tenha ocorrido, e, ainda, na completa ausência de qualquer intenção dolosa ou maliciosa, a ameaça que o indivíduo banido carregava do ponto de vista da ordem, rumo a uma possível desestabilização futura, seria suficiente. Trata-se do adversário político na visão schmittiana e do homo sacer agambeniano. Repita-se, a questão em tela não era a violação da lei, mas a ameaça do

\footnotetext{
${ }^{556}$ Cf. Steven DECAROLI. Op. cit., p. 55.

557 ARISTÓTELES. Política, 3. ed. Tradução de Mário da Gama Kury. Brasília: Editora Universidade de Brasília, 1997, p. 105.

${ }_{558}$ ARISTÓTELES. Op. cit., p. 83.

${ }^{559}$ ARISTÓTELES. Op. cit., p. 106.
} 
estabelecimento de uma nova lei ou, mais acertadamente, a possibilidade de essa ameaça se tornar a própria lei.

Para esses indivíduos, reconhecidos por Aristóteles como deuses entre os homens, não havia lei, pois eles mesmos são uma lei: “... de fato, um homem se tornaria ridiculo se tentasse legislar para eles, pois provavelmente eles diriam o que o leão disse na estória de Antistenes, quando as lebres discursaram na assembléia e pediram direitos iguais para todos $"$ "560. Por existirem como são, esses indivíduos obtêm autonomia e, do ponto de vista do Estado, comandam carisma e admiração. É justamente essa influência que é ameaçadora. Eles são modelos, exemplos de comportamento e, consequentemente, representam um princípio alternativo da ordem.

Sabemos de Aristóteles que a justiça é possível somente se a proporcionalidade for igualmente possível. Em suas notas sobre o banimento, a retirada do indivíduo mais influente e de mais sucesso deve ser lida como o meio de se atingir o que as leis per se não podem: uma sociedade proporcional. Mas podemos estender esse conceito. Não é somente por ser muito rico ou por ter muitos amigos que essas figuras são candidatas ao ostracismo, mas porque "... they play the game too well, follow the rules too cleverly, or with too much good fortune ${ }^{\text {"561 }}$. Eles chamam a atenção à fragilidade das regras - a limitação essencial do fair play e, em ultima análise, da justiça - e são convidados ao exílio.

Se é verdade que o banimento de cidadãos influentes é um meio de preservação da própria justiça, então temos no ostracismo uma das primeiras - e certamente uma das mais incisivas - assertivas com relação à utilidade política do banimento: "The state resorts to banishment when the social order within which one can decide on, or measure, the relative justness of an action is threatened by an influence that the law is powerless to regulate" ${ }^{\text {"562 }}$. Uma vez mais, não é somente porque esses indivíduos são ricos ou possuem muitos amigos que eles são banidos. Isso se dá porque quantias extraordinárias de riqueza $\mathrm{e}$ amizades engendradas ameaçam desafiar o fundamento em que repousa a lei, não violá-la. Nesses casos, quando o estilo de vida é ameaçado, o exercício do banimento serve como

\footnotetext{
${ }^{560}$ ARISTÓTELES. Op. cit., p. 105.

${ }^{561}$ DECAROLI, Steven. Op. cit., p. 58.

${ }^{562}$ DECAROLI, Steven. Op. cit., p. 58.
} 
alvo da justiça, quer dizer, alvo da ordem, porquanto o banimento é unicamente qualificado para preservar a ordem quando a lei não mais o pode.

A análise do banimento em Roma é igualmente interessante. Segundo Steven DECAROLI, muito embora relevante no contexto grego, é em Roma que o uso mais significante do banimento ocorre dentre as penalidades civis da republica. Segundo esse autor, o banimento romano se fundamenta em dois princípios. O primeiro é o princípio de que os direitos legais resultam do pertencimento a uma civitas e não poderia ser derivado de qualquer outra forma. Segundo, esses direitos eram exclusivamente outorgados e honrados por uma específica civitas e, consequentemente, ninguém podia deter cidadania simultânea em dois Estados diferentes.

Ainda assim, para entendermos o significado e função do instituto, precisamos confrontá-lo igualmente ao conceito de persona. Na antiga lei romana, persona se referia a qualquer um capaz de deter direitos. Por sua vez, o termo técnico para a posição de qualquer indivíduo considerado uma persona era o status. E, para se ter a completa capacidade jurídica de gozo, isto é, para se ter idoneidade de possuir direitos e obrigações, era necessário, no direito romano, que a pessoa fosse livre (status libertatis), cidadão romano (status civitatis) e independente do pátrio poder (status familiae - sui iuris, paterfamilias), como afirma THOMAS MARKY ${ }^{563}$. A soma de todas as capacidades conferidas a uma persona, a posse da qual daria à pessoa o status, era coletivamente indicada por um termo que havia sido usado à menção feita ao cidadão no registro do censo: caput, significando cabeça. Se um cidadão alterasse de qualquer forma o seu status, ou seja, se ele perdesse um desses três elementos - perda da liberdade, perda de direitos civis, ou mudança na posição na família -, ele sofreria o que foi denominado capitis deminutio, é dizer, perda de caput ou status ${ }^{564}$.

Capitis deminutio tinha três formas - maxima, media e minima - dependendo de qual dos três elementos do status foi primordialmente afetado. Portanto, os três elementos do integral status romano não eram permanentes e era possível que uma pessoa sofresse mudanças significantes num ou nos três desses elementos. Segundo leitura de DECAROLI, as Institutas descrevem a maneira pela qual a mudança do status era carreada:

\footnotetext{
${ }^{563}$ MARKY, Thomas. Curso elementar de direito romano. 8 ed. São Paulo: Saraiva, 1995, p. 29-35.

${ }^{564}$ Cf. Steven DECAROLI. Op. cit., p. 59.
} 
"The capitis deminutio is a change of status, which may happen in three ways: for it may be the greatest capitis deminutio, or the less, also called the middle, or the least. I. The greater capitis deminutio is, when a man loses both citizenship and his liberty; as they do who by a terrible sentence are made 'the slaves of punishment;' and freedmen, condemned to slavery for ingratitude towards their patrons; and all those who suffer themselves to be sold in order to share the price obtained. 2. The less or middle capitis deminutio is, when a man loses his citizenship, but retains his liberty; as is the case when anyone is fobidden the use of fire and water, or is deported to an island. 3. The least capitis deminutio is when a person`s status is changed without forfeiture either of citizenship or liberty; as when a person sui juris becomes subject to the power of another, or a person alieni juris becomes independent."

$\mathrm{Na}$ variante mediática da capitis deminutio, assim como na maior, a perda da cidadania resultava da perda da posição na família, porquanto somente cidadãos tinham o direito de deter uma família. No entanto, ao contrário da maior capitis deminutio, em que o status libertatis é perdido - e, com ele, o status civitatis -, segundo MOREIRA ALVES ${ }^{566}$, na mediática a liberdade é preservada, mas a pessoa que sofre a alteração do status perde a cidadania e, destarte, aos olhos do judiciário romano passa a ser considerado um estranho (peregrinus fit). Contudo, DECAROLI nos ensina que converter o cidadão à condição de estrangeiro não acontecia diretamente, citando passagem de Cícero, pois ninguém poderia ser forçado a tanto contra sua vontade:

"But making a stranger of a citizen did not proceed directly, as we learn from an important passage in Cicero's oration Pro Domo. Here we are told that it was an established maxim of Roman law that no one could cease to be a citizen against his will: 'Has not this principle been handed down to us from our ancestors, that no Roman citizen can be deprived of his liberty, or of his status as a citizen, unless he himself consents to such a thing?' Consequently, the loss of citizenship by the middle form of capitis deminutio could not be brought

${ }^{565}$ DECAROLI, Steven. Op. cit., p. 59 apud JUSTINIAN. The Institutes of Justinian. Translated by Thomas Collett Sanders. New York: Longmans, Green, 1910. bk. I, chap. 16.

${ }^{566}$ ALVES, José Carlos Moreira. Direito Romano. v. 1. 13. ed. Rio de Janeiro: Forense, 2003, p. 121-123. 
about by force, because, as Cicero testifies, the state was prohibited from compelling anyone to abandon their citizenship against their will. Since the middle variant of capitis deminutio did not entail a loss of liberty (free will), the question arises as to how the loss of civil status, and the banishment entailed in it, was enforced."

De fato, se ninguém poderia ser forçado a perder seu status - leia-se aqui perda da cidadania, mas não da liberdade - contra sua própria vontade, quem e por qual razão o indivíduo se submeteria a essa mudança? DECAROLI nos dá a resposta:

"The answer to this question is telling. Those condemned to banishment - those who lost citizenship without loss of freedom - were indirectly compelled to abandon citizenship by their own choosing. The means used to bring this about can be found in a passage from the Institutes quoted above, and specifically in the reference to being 'forbidden the use of fire and water'. The reference is to an ancient interdictio prohibiting Roman citizens from providing the sentenced person with the necessities of life. Unable to access food, fire and shelter, the sentenced person was driven to withdraw himself from the city - by his own volition."

Assim, o banimento era exercido não porque o indivíduo era privado de sua permanência na civitas, mas por meio do inacesso às necessidades básicas da vida. $\mathrm{A}$ privação de fogo e água (aquae et ignis interdictio) era um meio indireto de aplicação da sentença de banimento ou, nas palavras de THOMAS MARKY ${ }^{568}$, exílio voluntário a uma colônia latina, por exemplo. Enquanto o exílio não era explicitamente inserido na interdictio e a pessoa estava tecnicamente livre para permanecer na cidade, na prática a interdictio era um banimento à luz de seu abandono. FUSTEL DE COULANGES, asseverando que entre os gregos e os romanos a lei surgiu como uma parte da religião, explica-nos a gravidade da privação da água e do fogo, porquanto não devem ser entendidos como meros elementos naturais, mas como culto:

\footnotetext{
${ }^{567}$ DECAROLI, Steven. Op. cit., p. 60.

${ }^{568}$ MARKY, Thomas. Op. cit., p. 37.
} 
"Exilar algum homem era, na fórmula usada pelos romanos, interditá-lo do fogo e da água. Por este fogo deve entender-se o fogo dos sacrifícios, e por esta água, a água lustral. O exílio excluía, pois, o homem da religião... Ora, na religião estava a fonte de onde emanavam os seus direitos civis e políticos. $\mathrm{O}$ exilado, perdendo a religião da pátria, perdia, ao mesmo tempo, tudo isso. Excluído do culto da cidade, via-se privado, naquele momento, do seu culto domestico, tendo, assim, de apagar o seu lar., 569

Assim, o indivíduo era colocado à margem da lei - assim como um estrangeiro mesmo estando dentro do Estado, é dizer, removido da ordem e da proteção do campo soberano mesmo residindo em território romano. A vida desprovida das mais simples necessidades, abandonada nas profundezas do Estado, é a vida nua.

A origem do exílio ${ }^{570}$ sob a interdictio não foi, portanto, a remoção física do indivíduo da cidade, mas o abandono do indivíduo às consequências de sua retirada do império da lei. Ao contrário do banimento forçado - para uma ilha, exemplificativamente -, os sujeitos do interdictio eram, em última instância, responsáveis por seu próprio exílio. A lei, ao não ser aplicada a certos indivíduos, ao não os incluir em seu campo soberano, efetivamente determinou o destino de cada um deles em suas próprias mãos. Como notado por Aristóteles, o banimento é a consequência de uma recusa de governar, uma retirada do Estado de um indivíduo. Algo que, no modelo da história oficial imposta pela ditadura brasileira, pode ser comparado ao lema Brasil, ame-o ou deixe-o.

Justamente porque somente a cidadania é retirada do indivíduo, a vida restante da pessoa corresponde perfeitamente à categoria da vida nua de Agamben. De fato, quando a liberdade é perdida por meio do encarceramento, a pessoa permanece no campo soberano porquanto a lei continua a ser aplicada. No caso do banimento, entretanto, a liberdade é preservada precisamente porque a lei não mais é aplicada. E a vida que resta - extirpada de

\footnotetext{
${ }^{569}$ COULANGES, Fustel de. A cidade antiga. Tradução de Fernando de Aguiar. São Paulo: Martins Fontes, 2000, P. 218-219.

570 "Tanto na Grécia quanto em Roma, testemunhas mais antigas mostram que mais original do que a oposição entre direito e pena é a condição 'não qualificável nem como o exercício de um direito nem como situação penal' (Crifò, 1985, p.11) de quem parte para o exílio em conseqüência de um homicídio cometido ou de quem perde a cidadania porque torna-se cidadão de uma civitas foederata que goza do ius exili"'. AGAMBEN, Giorgio. Homo sacer: o poder soberano e a vida nua I. Tradução de Henrique Burigo. Belo Horizonte: Editora UFMG, 2002, p. 116.
} 
cidadania, privada das mais básicas necessidades de água e fogo e abandonada ao estrangeirismo mesmo no coração do Estado - é a vida nua.

Assim, o banimento está longe de ser uma consequência da criminalidade. Como Agamben observa, o que está em jogo no banimento não é a aplicação da lei ao crime, a determinação do ilícito em relação ao lícito, mas a base do governo soberano. O que demonstra ser o banimento mais antigo que a lei é sua preocupação não com a aplicação da justiça - o exercício judicial da lei -, mas com a constituição da autoridade soberana, pilar no qual algo como a justiça pode aparecer e permanecer plausível. Citando Robertson Smith e sua análise da cultura hebraica, Agamben traça uma paralela definição do termo:

"Uma outra notável usança hebraica é o bando (herem), com o qual um pecador ímpio, ou então inimigos da comunidade e do seu Deus, eram votados a uma total destruição. O bando é uma forma de consagração à divindade, e é por isso que o verbo 'banir' é às vezes vertido como 'consagrar' (Miq. 4.13) ou 'votar' (Lev. 27.28). Nos tempos mais antigos do Hebraísmo, ele implicava, porém, a completa destruição não somente da pessoa, mas de suas propriedades... somente os metais, depois de terem sido fundidos ao fogo, podiam ser incorporados no tesouro do santuário (Jos. 6.24). Mesmo o bestiame não era sacrificado, mas simplesmente morto, e a cidade consagrada não devia ser reconstruída (Dt. 13.16; Josh. 6.26). Um tal bando é um tabu, tornado efetivo pelo temor de penas sobrenaturais (Rs., 16.34) e, como no tabu, o perigo nele implícito era contagioso (Dt. 7.26); quem porta à sua casa uma coisa consagrada incorre no mesmo bando., ${ }^{571}$

Banimento, longe de ser uma mera punição a um crime, é emitido quando a vida de um indivíduo é tida virulenta a uma comunidade. Banimento é primordialmente uma reposta não a uma ação ilegal, mas a uma ameaça ao estabelecimento de uma nova lei. Um ato meramente criminal, não importando quanto desprezível, é de alguma forma previsto pela lei, ele pode ser acomodado pela lei e mitigado por uma punição. A ameaça à qual o

571 SMITH, W. Robertson. Lectures on the religion of the semites. London, 1984, 453-454 apud AGAMBEN, Giorgio. Homo sacer: o poder soberano e a vida nua I. Tradução de Henrique Burigo. Belo Horizonte: Editora UFMG, 2002, p. 84. 
banimento tipicamente responde, entretanto, não é dessa natureza, pois o banimento, ao expelir o corpo, também afasta a reivindicação da lei sobre o corpo.

Se nos referirmos a Schmitt, o que o banimento responde não é a violação da lei, mas a ameaça da ordem, seja por um excesso de amigos ou riqueza, como em Aristóteles, ou por meio do distúrbio da tranquilidade pública, ou, ainda, quando a autoridade soberana corre o risco de ser tida por arbitrária. A resposta não é ao crime, mas à influência persuasiva.

$\mathrm{Na}$ corrente era, é justamente contra a possibilidade de um futuro político distinto que o banimento é conduzido. Encontramos a soberania protegida por uma pretendida suspensão da lei, permitindo que qualquer cidadão - a polícia fantasmagórica - exerça o direito soberano com impunidade contra aqueles que de alguma forma não se adaptem ao campo soberano, algo que de JUDITH BUTLER qualifica como o aparato da mentalidade governamental $^{572}$. A condição daqueles que se recusam a consentir ao poder soberano encontra paralelos ao abandono do homo sacer, como veremos abaixo. É esta estrutura de bando que Agamben quer que reconheçamos, justamente para que dela possamos escapar.

\subsection{O HOMO SACER}

Para Agamben, mesmo naquelas sociedades em que, como na Grécia clássica, celebravam-se sacrifícios animais e se imolavam, ocasionalmente, vítimas humanas, a vida em si não era considerada sagrada ${ }^{573}$. Ela se tornava sagrada somente por meio de uma

\footnotetext{
572 "They are, rather, part of the apparatus of governmentality; their decision, the power they wield to 'deem' someone dangerous amd constitute them effectively as such, is a sovereign power, a ghostly and forceful resurgence of sovereignty in the midst of governmentality". In: Precarious life: the powers of mourning and violence. London and New York: Verso, 2006, p. 59.

${ }^{573} \mathrm{Um}$ tema essencial para a compreensão da filosofia de Agamben é a distinção entre consagrar e profanar, termos que são qualificados no capítulo Elogio da profanação da obra Profanações: "Os juristas romanos sabiam perfeitamente o que significa 'profanar'. Sagradas ou religiosas eram as coisas que de algum modo pertenciam aos deuses. Como tais, elas eram subtraídas ao livre uso e ao comércio dos homens, não podiam ser vendidas nem dadas como fiança, nem cedidas em usufruto ou gravadas de servidão. Sacrilégio era todo ato que violasse ou transgredisse esta sua especial indisponibilidade, que as reservava exclusivamente aos deuses celestes (nesse caso eram denominadas propriamente 'sagradas') ou infernais (nesse caso eram simplesmente chamadas 'religiosas'). E se consagrar (sacrare) era o termo que designava a saída das coisas da esfera do direito humano, profanar, por sua vez, significava restitui-las ao livre uso dos homens. 'Profano'- podia escrever o grande jurista Trebácio - 'em sentido próprio denomina-se àquilo que, de sagrado ou religioso que era, é devolvido ao uso e à propriedade dos homens'. E 'puro' era o lugar que havia sido desvinculado da sua destinação aos deuses dos mortos e já não era 'nem sagrado, nem santo, nem religioso, libertado de todos os nomes desse gênero' (D.11,7,2)". É com essas premissas que Agamben exteriorizará que a religião pode ser definida como aquilo que "subtrai coisas, lugares, animais ou pessoas
} 
série de rituais, cujo objetivo era justamente o de separá-la do seu contexto profano. Para tornar alguém sagrado, é preciso separá-lo do mundo dos viventes, ou seja, é preciso que ele atravesse o limiar que separa os dois universos. Se assim o é, então a partir de quando a vida humana tornou-se sagrada?

Para responder a essa questão, Agamben invoca a figura denominada homo sacer" $^{574}$, "uma obscura figura do direito romano arcaico, na qual a vida humana é incluída no ordenamento unicamente sob a forma de sua exclusão (ou seja, de sua absoluta matabilidade)" 575 .

Em particular, ele levanta a definição de homo sacer dada por POMPEIUS FESTUS, que escreve, em seu tratado sobre o significado das palavras: "At homo sacer is est, quem populus iudicavit ob maleficium; neque fas est eum immolari, sed qui occidit, parricidi non damnatur; nam lege tribunicia prima cavetur 'si quis eum, qui eo plebei scito sacer sit,

ao uso comum e as transfere para uma esfera privada", isto é, não somente inexiste religião sem separação, como toda separação conserva em si um caráter religioso. A passagem do profano ao sagrado (da esfera humana à divina) dá-se por meio do sacrifício (rituais segundo a variedade das culturas) e, o contrário (do sagrado ao profano) dá-se por atos simples como o mero contato (contagione) com o ser sagrado. Cf. Giorgio AGAMBEN. In: Profanações. Tradução Selvino José Assmann. São Paulo: Boitempo, 2007, p. 65-67.

574 Quanto à origem etimológica do termo, Agamben esclarece: "Os filólogos não cansam de ficar surpreendidos com o dúplice e contraditório significado que o verbo profanare parece ter em latim: por um lado, tornar profano, por outro - em acepção atestada só em poucos casos - sacrificar. Trata-se de uma ambigüidade que parece inerente ao vocabulário do sagrado como tal: o adjetivo sacer, com um contrasenso que Freud já havia percebido, significaria tanto 'augusto, consagrado aos deuses', como 'maldito, excluido da comunidade'. A ambiguidade, que aqui está em jogo, não se deve apenas a um equívoco, mas é, por assim dizer, constitutiva da operação profanatória (ou daquela inversa, da consagração). Enquanto se referem a um mesmo objeto que deve passar do profano ao sagrado e do sagrado ao profano, tais operações devem prestar contas, cada vez, a algo parecido com um resíduo de profanidade em toda coisa consagrada e a uma sobra de sacralidade presente em todo objeto profanado. Veja-se o termo sacer. Ele designa aquilo que, através do ato solene da sacratio ou da devotio (com que o comandante consagra a sua vida aos deuses do inferno para assegurar a vitória), foi entregue aos deuses, pertence exclusivamente a eles. $O$ que aconteceu de fato nesse caso? Um homem sagrado, ou seja, pertencente aos deuses, sobreviveu ao rito que o separou dos homens e continua levando uma existência aparentemente profana entre eles. No mundo profano, é inerente ao seu corpo um resíduo irredutivel de sacralidade, que o subtrai ao comércio normal com seus semelhantes e o expõe à possibilidade da morte violenta, que o devolve aos deuses aos quais realmente pertence; considerado, porém, na esfera divina, ele não pode ser sacrificado e é excluído do culto, pois sua vida já é propriedade dos deuses e, mesmo assim, enquanto sobrevive, por assim dizer, a si mesma, ela introduz um resto incongruente de profanidade no âmbito do sagrado. Sagrado e profano representam, pois, na máquina do sacrifício, um sistema de dois pólos, no qual um significante flutuante transita de um âmbito para outro sem deixar de se referir ao mesmo objeto. Mas é precisamente desse modo que a máquina pode assegurar a partilha do uso entre os humanos e os divinos e pode devolver eventualmente aos homens o que havia sido consagrado aos deuses. Dai nasce a promiscuidade entre as duas operações no sacrificio romano, na qual uma parte da própria vítima consagrada acaba profanada por contágio e consumida pelos homens, enquanto outra é entregue aos deus". Cf. Giorgio AGAMBEN. In: Profanações. Tradução Selvino José Assmann. São Paulo: Boitempo, 2007, p. 68-69.

${ }^{575}$ AGAMBEN, Giorgio. Homo sacer: o poder soberano e a vida nua I. Tradução de Henrique Burigo. Belo Horizonte: Editora UFMG, 2002, p. 16. 
occiderit, parricidi ne sit'. Ex quo quivis homo malus atque improbus sacer appelari solet ${ }^{, 576}$.

Isto é, embora a figura apresente traços à primeira vista contraditórios ${ }^{577} \mathrm{e}$ "resultasse obscura até mesmo para os romanos",578, existindo, segundo o próprio Agamben, divergência conceitual nas interpretações modernas ${ }^{579}$, uma análise mais cuidadosa revela a especificidade do homo sacer: " a impunidade da sua morte e o veto de seu sacrificio" "580 (l'impunità della sua uccisione e il divieto di sacrificio):

"Primeiramente, o impune occidi configura uma exceção do ius humanum, porquanto suspende a aplicação da lei sobre homicídio atribuída a Numa ( $s i$ quis hominem liberum dolo sciens morti duit, parricidas esto). A própria fórmula referida por Festo (qui occidit, parricidi non damnatur), aliás, constitui de certo modo uma vera e própria exceptio em sentido técnico, que o assassino chamado em juízo poderia opor à acusação, invocando a sacralidade da vítima. Mas até mesmo o neque fas est eum immolari configura, observando-se bem, uma exceção, desta vez do ius divinum e de toda e qualquer forma de morte ritual. As formas mais antigas de execução capital de que temos notícias (a terrível poena cullei, na qual o condenado, com a cabeça coberta por uma pele de lobo, era encerrado em um saco com serpentes, um cão e um galo, e jogado n'água; ou a defenestração da Rupe Tarpea) são, na

\footnotetext{
576 “Homem sacro é, portanto, aquele que o povo julgou por um delito; e não é lícito sacrificá-lo, mas quem o mata não será condenado por homicídio; na verdade, na primeira lei tribunícia se adverte que 'se alguém matar aquele que por plebiscito é sacro, não será considerado homicida'. Disso advém que um homem malvado ou impuro costuma ser chamado sacro" e, portanto, há uma simbiose entre veneração e horror a ele". In: FESTUS, Pompeius. De uerborum significatu apud AGAMBEN, Giorgio. Homo sacer: o poder soberano e a vida nua I. Tradução de Henrique Burigo. Belo Horizonte: Editora UFMG, 2002, p. 196

577 Para Giorgio AGAMBEN, "A contradição é ainda acentuada pela circunstância de que aquele que qualquer um podia matar impunemente não devia, porém, ser levado à morte nas formas sancionadas pelo rito (neque fas est eum immolari; immolari indica o ato de aspergir a vítima com a mola salsa antes de sacrificá-la)." AGAMBEN, Giorgio. Homo sacer: o poder soberano e a vida nua I. Tradução de Henrique Burigo. Belo Horizonte: Editora UFMG, 2002, p. 79.

${ }^{578}$ AGAMBEN, Giorgio. Homo sacer: o poder soberano e a vida nua I. Tradução de Henrique Burigo. Belo Horizonte: Editora UFMG, 2002, p. 80.

579 Para Giorgio AGAMBEN, "Aqui o campo é dividido entre aqueles (como Mommsen, Lange, Bennett, Strachan-Davidson) que vêem na sacratio o resíduo enfraquecido e secularizado de uma fase arcaica na qual $o$ direito religioso e o penal não eram ainda distintos, e a condenação à morte se apresentava como um sacrificio à divindade, e aqueles (como Kerényi e Fowler) que reconhecem nessa figura arquetípica do sacro a consagração aos deuses inferos, análoga, na sua ambigüidade, à noção etnológica de tabu: augusto e maldito, digno de veneração e suscitante de horror." Cf. Giorgio AGAMBEN. In: Homo sacer: o poder soberano e a vida nua I. Tradução de Henrique Burigo. Belo Horizonte: Editora UFMG, 2002, p. 80.

${ }^{580}$ AGAMBEN, Giorgio. Homo sacer: o poder soberano e a vida nua I. Tradução de Henrique Burigo. Belo Horizonte: Editora UFMG, 2002, p. 81.
} 
realidade, antes ritos de purificação que penas de morte no sentido moderno: o neque fas est eum immolari serviria justamente para distinguir matança do homo sacer das purificações rituais e excluiria a sacratio do âmbito religioso em sentido próprio., ${ }^{, 51}$

É dizer, o fato de o homem sagrado poder ser morto, mas não sacrificado, significa que esse sujeito está fora da abrangência da lei humana, porque “... aquilo que já é sacer já está sob a posse dos deuses" ${ }^{582}$, e simultaneamente excluído da lei divina, porque ser sacrificado é ser dado aos deuses, um destino do qual o homem sagrado é excluído. Isto é, a pessoa do homo sacer não passa do profano ao sacro, da violência humana à violência divina, mas “... é simplesmente posta fora da jurisdição humana sem ultrapassar para a divina" ${ }^{, 53}$, quer dizer, é sempre flutuante e de indiferenciação como comenta MILTON MEIRA DO NASCIMENTO ${ }^{584}$. Mas qual o significado de uma pessoa sagrada que pode ser matada sem que se cometa contaminação ou sacrilégio e, ao mesmo tempo, não pode ser levado à morte nas formas prescritas?

Agamben dirá que devemos procurar a resposta numa “... estrutura política originária, que tem seu lugar em uma zona que precede a distinção entre sacro e profano, entre religioso e jurídico" ${ }^{, 55}$. Parece-nos que, para Agamben, a resposta nunca será satisfatória se não eliminarmos essa distinção, pois reside justamente na indiscernibilidade do status do homo sacer. É assim que Agamben rejeita a explanação dessas características por meio do argumento de uma ambiguidade essencial do homem sagrado na base da circularidade, e prefere defender que o homem sagrado é mais apropriadamente entendido como uma dupla exclusão e uma dupla captura, seja do âmbito religioso, seja do profano. Agamben tenta escapar da distinção entre sacro e profano, religioso e jurídico, para lançar luz sobre sua já comentada forma originaria del diritto. O homo sacer não está sob o ius

\footnotetext{
581 AGAMBEN, Giorgio. Homo sacer: o poder soberano e a vida nua I. Tradução de Henrique Burigo. Belo Horizonte: Editora UFMG, 2002, p. 89.

582 AGAMBEN, Giorgio. Homo sacer: o poder soberano e a vida nua I. Tradução de Henrique Burigo. Belo Horizonte: Editora UFMG, 2002, p. 80.

${ }^{583}$ AGAMBEN, Giorgio. Homo sacer: o poder soberano e a vida nua I. Tradução de Henrique Burigo. Belo Horizonte: Editora UFMG, 2002, p. 89.

${ }^{584}$ In: Dentro e fora da lei. Jornal de resenhas, n. 91, de abril de 2001 a novembro de 2002. São Paulo: Discurso Editorial, 2002, p. 2509.

${ }^{585}$ AGAMBEN, Giorgio. Homo sacer: o poder soberano e a vida nua I. Tradução de Henrique Burigo. Belo Horizonte: Editora UFMG, 2002, p. 81.
} 
divinum, nem sob o ius humanum (não/nem). A condição do homo sacer, assim como do devotus ${ }^{586}$, é esclarecida no texto Elogio da profanação, como segue:

"O que aconteceu de fato nesse caso? Um homem sagrado, ou seja, pertencente aos deuses, sobreviveu ao rito que o separou dos homens e continua levando uma existência aparentemente profana entre eles. No mundo profano, é inerente ao seu corpo um resíduo irredutível de sacralidade, que o subtrai ao comércio normal com seus semelhantes e o expõe à possibilidade da morte violenta, que o devolve aos deuses aos quais realmente pertence; considerado, porém, na esfera divina, ele não pode ser sacrificado e é excluído do culto, pois sua vida já é propriedade dos deuses e, mesmo assim, enquanto sobrevive, por assim dizer, a si mesma, ela introduz um resto incongruente de profanidade no âmbito do sagrado. ${ }^{\$ 87}$

Agamben explica que a dupla exclusão do homem sagrado aponta para a correlativa dupla inclusão na instancias do divino e do humano, uma vez que a caracterização de o homo sacer ser passível de assassínio e não sacrificável também indica a inclusão do homo sacer dentro da comunidade humana e sua propriedade pelos deuses. JESSICA WhYTE comenta a dupla exceção:

\footnotetext{
${ }^{586}$ Agamben traça um paralelo entre o homo sacer e o devotus, ou seja, aquele que, por meio de um ritual, consagra a própria vida aos deuses ínferos para salvar a cidade de um grave perigo. O devotus era aquele que era votado à morte para a proteção e vitória do povo romano e, portanto, pertencente aos deuses. Se ele morresse em batlha, realizou-se o premeditado, mas, se não morre, "a sobrevivência do devoto constitui para a comunidade uma situação embaraçosa, a ponto de obrigá-la ao cumprimento de um coplexo ritual", porquanto o estatuto desse corpo vivente parece não mais pertencer ao mundo dos vivos. Ou seja, o devoto sobrevivente é excluído tanto do mundo profano quanto do sagrado: ele é sacer. Para que o devoto pudesse ser restituído ao mundo profano (já que ele não poderia fazê-lo justamente porque graças a seu voto que toda a comunidade pôde escapar à ira dos deuses), "um colosso podia ser confeccionado" de cera para representar (e não apenas substituir) aquela parte da pessoa viva que é destinada à morte e que, "ocupando ameaçadoramente o limiar entre os dois mundos, deve ser separada do contexto normal dos vivos". Enquanto não se cumpre esse rito, "o devoto sobrevivente é um ser paradoxal que, parecendo prosseguir numa vida aparentemente normal, se move, na realidade, em um limiar que não pertence nem ao mundo dos vivos nem ao dos mortos; ele é um morto vivente ou um vivo que é, na verdade, uma larva, e o colosso representa justamente aquela vida consagrada que se havia já virtualmente separado dele no momento do voto". E Agamben conclui: “... Tanto no corpo do devoto sobrevivente como, de modo ainda mais incondicionado, no corpo do homo sacer, o mundo antigo se encontra pela primeira vez diante de uma vida que, excepcionando-se em uma dupla exclusão do contexto real das formas de vida, sejam profanas ou religiosas, é definido apenas pelo seu ser em íntima simbiose com a morte, sem porém pertencer ainda no mundo dos defuntos". In: Homo sacer: o poder soberano e a vida nua I. Tradução de Henrique Burigo. Belo Horizonte: Editora UFMG, 2002, p. 104-107.

${ }^{587}$ AGAMBEN, Giorgio. Profanações. Tradução Selvino José Assmann. São Paulo: Boitempo, 2007, p. 69.
} 
“... while the unpunishability of his killing removed homo sacer from the sphere of human law, the ban on sacrifices excludes him from the realm of the divine law. ${ }^{, 588}$

O homo sacer pertence aos deuses na forma de uma insacrificabilidade e é, ainda assim, incluído na comunidade humana, pois passível de ser morto: impunidade da matança e exclusão do sacrifício. Agamben conclui dessa situação contraditória que a vida sagrada ou nua é vida além do divino e do profano e, portanto, é vida singularmente exposta - ou melhor, destinada - à morte.

Entretanto, a dupla exclusão e a dupla captura do homo sacer significa que a zona em que a vida nua persiste não é sem lei, mas revela a exclusão inclusiva ou abandono da vida nua em relação à lei. Outrossim, revela uma convergência entre o homo sacer e a exceção, porquanto cada qual é simultaneamente incluído e excluído da lei e, destarte, sujeito a uma decisão soberana. É com essas bases que Agamben indica a figura do homo sacer como a relação originaria política, uma vez que ele relembra a memória das exclusões que fundaram a esfera político-juridica como uma excrescência da religião e da profanação, e ilumina a indistinção entre violência que deita no íntimo do poder soberano: “... Assim como, na exceção soberana, a lei se aplica de fato ao caso excepcional desaplicando-se, retirando-se deste, do mesmo modo o homo sacer pertence ao Deus na forma da insacrificabilidade e é incluido na comunidade na forma da matabilidade. A vida insacrificável e, todavia matável, é a vida sacra" ${ }^{589}$.

Aí reside a conexão entre as estruturas da soberania e da sacratio. Em outras palavras, aqueles em abandono ou aqueles que, de outra forma, foram removidos da jurisdição da lei, são feitos homo sacer precisamente porque, embora estejam colocados fora da lei e de sua proteção, preservam uma relação extralegal com essa mesma lei por meio de sua exclusão dela: “. . a sacrabilidade da vida, que se desejaria hoje fazer valer contra o poder soberano como um direito humano em todos os sentidos fundamental,

\footnotetext{
${ }^{588}$ WHYTE, Jessica. Op. cit., p. 72.

589 AGAMBEN, Giorgio. Homo sacer: o poder soberano e a vida nua I. Tradução de Henrique Burigo. Belo Horizonte: Editora UFMG, 2002, p. 90.
} 
exprime, ao contrário, em sua origem, justamente a sujeição da vida a um poder de morte, a sua irreparável exposição na relação de abandono" ${ }^{\text {"590 }}$.

Nesse cenário, num regime de biopolítica todos os sujeitos são potenciais homo sacer, ou seja, todos os sujeitos são abandonados pela lei e expostos à violência como condição constitutiva da existência política. Ou melhor, “... restituído ao seu lugar próprio, além tanto do direito penal quanto do sacrificio, o homo sacer apresentaria a figura originária da vida presa no bando soberano e conservaria a memória da exclusão originária através da qual se constituiu a dimensão política" ${ }^{\text {"591. }}$.

Parece-nos, assim, que o preço da participação na vida política é a exposição à morte na figura da dupla exceção. Sob esse fio-condutor, Agamben define a relação entre soberania e o homo sacer: "Soberana é a esfera na qual se pode matar sem cometer homicídio e sem celebrar um sacrificio, e sacra, isto é, matável e insacrificável, é a vida que foi capturada nesta esfera" ${ }^{\text {} 592}$. Fica claro finalmente porque Agamben entende que

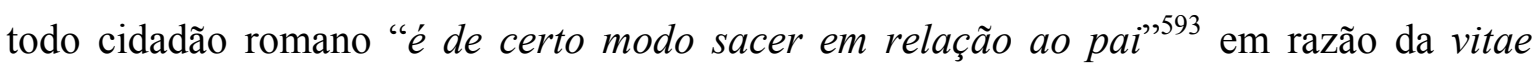
necisque potestas, porquanto exposto à sua matabilidade, assim como todo cidadão está exposto à morte pelo soberano. A implicação da vida nua do filho varão é trazida à esfera soberana na ordem jurídico-política:

“... o imperium do magistrado nada mais é que a vitae necisque potestas do pai estendida em relação a todos os cidadãos. Não se poderia dizer de modo mais claro que o fundamento primeiro do poder politico é uma vida absolutamente matável, que se politiza através de sua própria matabilidade." ${ }^{\text {594 }}$

Portanto, a sacrabilidade da vida emerge somente na extensão em que a vida é incorporada na exceção soberana: a sacrabilidade da vida permite sua captura dentro da

\footnotetext{
${ }^{590}$ AGAMBEN, Giorgio. Homo sacer: o poder soberano e a vida nua I. Tradução de Henrique Burigo. Belo Horizonte: Editora UFMG, 2002, p. 91.

${ }^{591}$ AGAMBEN, Giorgio. Homo sacer: o poder soberano e a vida nua I. Tradução de Henrique Burigo. Belo Horizonte: Editora UFMG, 2002, p. 91.

${ }_{592}$ AGAMBEN, Giorgio. Homo sacer: o poder soberano e a vida nua I. Tradução de Henrique Burigo. Belo Horizonte: Editora UFMG, 2002, p. 91.

${ }^{593}$ AGAMBEN, Giorgio. Homo sacer: o poder soberano e a vida nua I. Tradução de Henrique Burigo. Belo Horizonte: Editora UFMG, 2002, p. 97.

${ }_{594}$ AGAMBEN, Giorgio. Homo sacer: o poder soberano e a vida nua I. Tradução de Henrique Burigo. Belo Horizonte: Editora UFMG, 2002, p. 96.
} 
exceção soberana e a concomitante produção da vida nua. A sacrabilidade constitui a forma originaria da inclusão da vida nua na ordem jurídica, e o sintagma homo sacer traz à luz a exclusão inclusiva da vida nua na ordem política como objeto da decisão soberana e, portanto, dá nome à relação política originaria:

"Sacra, isto é, matável e insacrificável, é originariamente a vida no bando soberano, e a produção da vida nua é, neste sentido, o préstimo original da soberania." 595

Uma simetria ainda mais firme torna-se então aparente entre o homo sacer e o soberano, pois “... soberano é aquele em relação ao qual todos os homens são potencialmente homines sacri e homo sacer é aquele em relação ao qual todos os homens agem como soberanos" $" 596$. Essa simetria entre os corpos do soberano e do homo sacer é trazida à modernidade por meio de um exemplo:

"Um primeiro e imediato confronto é oferecido pela sanção que castiga o assassinato do soberano. Sabemos que o assassinato do homo sacer não constitui homicídio (parricidi non damnatur). Pois bem: não existe nenhum ordenamento (nem mesmo entre aqueles em que o homicídio é sempre punido com a pena capital) no qual o assassinato do soberano tenha sido sempre simplesmente assinalado como um homicídio. Ele constitui, em vez disso, um delito especial que (depois que, a partir de Augusto, a noção de maiestas associa-se cada vez mais intimamente à pessoa do imperador) é definido como crimen lesae maiestatis. Não importa, do nosso ponto de vista, que a morte do homo sacer possa ser considerada como menos que um homicídio, e a do soberano como mais que um homicídio: essencial é que, nos dois casos, a morte de um homem não verifique o caso jurídico do homicídio." ${ }^{597}$

Um segundo exemplo, ainda de acordo com as instituições modernas, “... sobrevive no princípio segundo o qual o chefe de Estado não pode ser submetido a um processo

\footnotetext{
${ }^{595}$ AGAMBEN, Giorgio. Homo sacer: o poder soberano e a vida nua I. Tradução de Henrique Burigo. Belo Horizonte: Editora UFMG, 2002, p. 91.

${ }^{596}$ AGAMBEN, Giorgio. Homo sacer: o poder soberano e a vida nua I. Tradução de Henrique Burigo. Belo Horizonte: Editora UFMG, 2002, p. 92.

${ }^{597}$ AGAMBEN, Giorgio. Homo sacer: o poder soberano e a vida nua I. Tradução de Henrique Burigo. Belo Horizonte: Editora UFMG, 2002, p. 110.
} 
judiciário ordinário" ${ }^{\text {598 }}$. É dizer, o soberano parece ser uma exclusão do direito a todos aplicado. Mais importante que esses exemplos, contudo, é a exposição moderna à morte nas formas mais banais: "O nosso tempo é aquele em que um week-end de feriado produz mais vitimas nas auto-estradas da Europa do que uma campanha bélica" ${ }^{\text {"599 }}$, até mesmo porque, na biopolítica atual, "o soberano entra em simbiose cada vez mais íntima não só com o jurista, mas também com o médico, com o cientista, com o perito, com o sacerdote" ${ }^{, 600}$. A relação dá-se nos diversos sistemas comunicativos da sociedade biopolítica.

Seja como for, Agamben esforça-se na caracterização do homo sacer como elemento da cidade moderna justamente para que todos nós - homines sacri reconheçamos nossa condição de exposição à morte e, ato contínuo, tenhamos a possibilidade de sobreviver à polícia que nos cerca, bem como à lógica da segurança dos governos, rumo a uma nova política livre de qualquer soberania ou direito.

\subsection{O CAMPO MODERNO}

Em sua trilogia, Agamben exterioriza que o campo - seja de refugiados, seja de concentração, seja o que hoje vivemos e ainda inominado - é o paradigma biopolítico da atualidade; nada menos que a materialização do estado de exceção. Entendendo o campo não como um espaço físico ou uma anomalia histórica, mas como a atual condição da vida política, um paradigma ${ }^{601}$ de governo ${ }^{602}$, Agamben argumenta que as circunstâncias

598 AGAMBEN, Giorgio. Homo sacer: o poder soberano e a vida nua I. Tradução de Henrique Burigo. Belo Horizonte: Editora UFMG, 2002, p. 110.

599 AGAMBEN, Giorgio. Homo sacer: o poder soberano e a vida nua I. Tradução de Henrique Burigo. Belo Horizonte: Editora UFMG, 2002, p. 121.

${ }^{600}$ AGAMBEN, Giorgio. Homo sacer: o poder soberano e a vida nua I. Tradução de Henrique Burigo. Belo Horizonte: Editora UFMG, 2002, p. 128.

601 "It is the nexus between the paradox of sovereignty, the sacred, and biopolitics that makes the concentration camp the paradigm of modern politics, with the German Nazi regime expressing its outer limit. If Agamben is right, the emerge of biopolitics plunges the paradox of sovereignty beyond constitutional disputes over democratic rule into the very logic of Nazi Holocaust". Aliás, é justamente por entender a gravidade dessa lógica que Agamben insiste em sua superação. CONNOLLY, William E. Op. cit., p. 27.

602 "É por um paradoxo apenas aparente que o inócuo cidadão das democracias pós-industriais (o bloom, como eficazmente se sugeriu chamá-lo), que executa pontualmente tudo o que lhe é dito e deixa que os seus gestos quotidianos, como sua saúde, os seus divertimentos, como suas ocupações, a sua alimentação e como seus desejos sejam comandados e controlados por dispositivos até nos mínimos detalhes, é considerado pelo poder - talvez exatamente por isso - como um terrorista virtual. Enquanto a nova normativa européia impõe assim a todos os cidadãos aqueles dispositivos biométricos que desenvolvem e aperfeiçoam as tecnologias antropométricas (das impressões digitais à fotografia sinalética) que foram inventadas no século XIX para a identificação dos criminosos reincidentes, a vigilância por meio de videocâmera transforma os espaços públicos das cidades em áreas internas de uma prisão. Aos olhos da autoridade - e, talvez, esta tenha razão - 
inerentes a priori ao campo foram gradualmente estendidas à totalidade das populações civis ${ }^{603}$ : “A novidade é que, agora... o campo é o espaço que se abre quando o estado de exceção começa a tornar-se regra" ${ }^{\circ 04}$.

No campo, o estado de exceção, que era essencialmente uma temporal suspensão do estado de direito, adquire um arranjo espacial permanente, que, como tal, permanece constantemente fora do estado da lei normal. Como uma figura topológica, a essência revelada no campo é aquela de normalização da exceção: o campo materializa o paradigma jurídico-político no qual norma se torna indistinguível da exceção, quer dizer, no qual a exceção é realizada normalmente.

Assim, o campo é uma função não da lei, mas do estado de exceção no qual a lei é suspensa: uma zona onde tudo é verdadeiramente possível. Um espaço onde ocorre a destruição de todo status político, um espaço onde são produzidas vidas nuas, um espaço onde a lei se transforma em fato e o fato em lei, de maneira que os dois planos se tornam indistinguíveis: “... observando-se bem, no campo a quaestio iuris não é mais absolutamente distinguivel da quaestio facti e, neste sentido, qualquer questionamento sobre a legalidade ou ilegalidade daquilo que nele sucede é simplesmente desprovido de sentido. O campo é um híbrido de direito e de fato, no qual os dois termos tornaram-se indiscerníveis" ${ }^{\prime 605}$. A título de exemplo, o cenário que se seguiu ao Verordnung zum Schutz von Volk und Staat de 1933 na Alemanha é de extrema significância:

"Tome-se o caso do Estado nazista. Logo que tomou o poder (ou, como talvez se devesse dizer de modo mais exato, mal o poder lhe foi entregue), Hitler promulgou, no dia 28 de fevereiro, o Decreto para a proteção do povo e do

\footnotetext{
nada se assemelha melhor ao terrorista do que o homem comum". AGAMBEN, Giorgio. In: O que é contemporâneo? e outros ensaios. Tradução Vinícius Nicastro Honesko. Chapecó: Argos, 2009, p. 49.

${ }^{603}$ Ao tratar da relação entre polícia e consolidação da democracia, Paulo Sérgio PINHEIRO detecta algumas dessas zonas de indistinção e expõe que "vastas zonas de não-estado de direito escapam ao controle do governo federal. Entre essas áreas incluem-se as urbanas - como os bairros populares das nove maiores regiões metropolitanas; por exemplo, a periferia de São Paulo e os morros do Rio de Janeiro, submetidas ao terror de crime organizado e do tráfico de drogas, dispondo de verdadeiras milícias - e as áreas rurais aquelas unidades da federação com nivel inferior de desenvolvimento humano, onde as elites locais instrumentalizam as instituições como as polícias militares e se valem de milícias particulares em suas propriedades". In: Polícia e consolidação democrática: o caso brasileiro. In: São Paulo sem medo: um diagnóstico da violência urbana. Rio de Janeiro: Garamond, 1998, p. 175.

${ }^{604}$ AGAMBEN, Giorgio. Homo sacer: o poder soberano e a vida nua I. Tradução de Henrique Burigo. Belo Horizonte: Editora UFMG, 2002, p. 175.

${ }^{605}$ AGAMBEN, Giorgio. Homo sacer: o poder soberano e a vida nua I. Tradução de Henrique Burigo. Belo Horizonte: Editora UFMG, 2002, p. 177.
} 
Estado, que suspendia artigos da Constituição de Weimar relativos às liberdades individuais. O decreto nunca foi revogado, de modo que todo o Terceiro Reich pode ser considerado, do ponto de vista jurídico, como um estado de exceção que durou doze anos. O totalitarismo moderno pode ser definido, nesse sentido, como a instauração, por meio do estado de exceção, de uma guerra civil legal que permite a eliminação física não só dos adversários políticos, mas também de categorias inteiras de cidadãos que, por qualquer razão, pareçam não integráveis ao sistema político.”606

O campo estruturado pelo nazismo não indica um espaço meramente topográfico de confinamento, mas é, ao contrário, a figura topológica da soberania que une lei e violência dentro da exceção. Isso significa que, ao invés de descrever uma posição específica, Agamben sugere que o espaço de exceção do campo revela uma lógica abstrata de abandono, que de forma alguma é limitada pelo espaço geográfico de internamento.

Na teoria agambeniana, Auschwitz é exatamente o lugar em que estado de exceção coincide, de maneira perfeita, com a regra, e a situação extrema converte-se no próprio paradigma do cotidiano ${ }^{607}$. OLGÁRIA MATOS parece concordar com o pensamento de Agamben ao discorrer que “... o nazismo como mal radical é o emblema do estado de exceção em que vive a modernidade. O Estado tem direito de vida, isto é, de morte sobre os cidadãos, ao garantir a vida, designa a morte. A desvalorização da vida coincide com a afirmação ideológica de seu valor. Todos se encontram na condição do Homo sacer" ${ }^{608}$.

No ensaio We refugees (intitulado Beyond Human Rights na tradução inglesa de Mezzi senza fine) escrito por Agamben em homenagem ao texto que leva o mesmo título publicado por Hannah Arendt no The Menorah Journal em 1943, Agamben assevera que as palavras da autora, 50 anos depois - o texto é de 1993 - , não param de ressoar, pois "One of the few rules the Nazis faithfully observed in the course of the 'final solution' was that only after the Jews and gypsies were completely denationalized (even of that secondclass citizenship that belonged to them after the Nuremberg laws) could they be sent to the

\footnotetext{
${ }^{606}$ AGAMBEN, Giorgio. Estado de exceção. Tradução de Iraci D. Poleti. São Paulo: Boitempo, 2004, p. 13. ${ }^{607}$ Cf. Giorgio AGAMBEN. O que resta de Auschwitz: o arquivo e a testemunha. Tradução de Selvino J. Assmann. São Paulo: Boitempo, 2008, p. 57.

${ }^{608}$ MATOS, Olgária. Modernidade: república em estado de exceção. Op. cit., p. 46.
} 
extermination camps. When the rights of man are no longer the rights of the citizen, then he is truly sacred, in the sense that this term had in archaic Roman law: destined to die" ${ }^{, 609}$.

Nessa profusão de problemas, Agamben afirma que todas as vezes em que o fenômeno do refugiado foi colocado como questão de massa, as organizações humanitárias - Organização das Nações Unidas, exemplificativamente - foram incapazes de resolver adequadamente a matéria ${ }^{610}$ : “... these organizations and the single states have proven, despite the solemn evocations of the inalienable rights of man, to be absolutely incapable not only of resolving the problem but also simply of dealing with it adequately"611. Em outras palavras, "In the system of the nation-state, so-called sacre and inalienable human rights are revealed to be without any protection precisely when it is no longer possible to conceive of them as rights of the citizens of a state" ${ }^{\# 12}$. Ou seja, aqueles que mais precisavam dos chamados direitos inalienáveis, aqueles sem direito à cidadania, não estavam em posição de reclamá-los, segundo HANNAH ARENDT:

"Nenhum paradoxo da política contemporânea é tão dolorosamente irônico como a discrepância entre os esforços de idealistas bem-intencionados, que persistiam teimosamente em considerar 'inalienáveis' os direitos desfrutados pelos cidadãos dos países civilizados, e a situação de seres humanos sem direito algum. Essa situação deteriorou-se, até que o campo de internamento que antes da Segunda Guerra Mundial, era exceção e não a regra para os grupos apátridas - tornou-se uma solução de rotina para o problema domiciliar dos 'deslocados de guerra'... A dificuldade surgiu em conseqüência de fracassos da aplicação dos dois remédios reconhecidos como válidos: a repatriação e a naturalização. As medidas de repatriação falharam, pois nenhum país aceitou admitir aquelas pessoas... Todas as tentativas das conferências internacionais no sentido de estabelecer alguma condição legal

\footnotetext{
609 AGAMBEN, Giorgio. We refugees. Traduçao de Michael Rocke. Disponível em http://www.egs.edu/faculty/giorgio-agamben/articles/we-refugees/. Acessado em 2.6.2009.

${ }^{610}$ De acordo com Djacir MENEZES, “... deixo claro, com uma clareza que raia na ingenuidade, que é de todo ridículo supor que os estadistas reunidos nos tribunais internacionais acreditem nas mitologias que ali advogam. Jamais atacam as raízes da beligerância vigente, a que servem dissimuladamente". In: Os equívocos da noção de soberania. In: Carta mensal, Rio de Janeiro, 30 (355): 17-22, Out. 1984, p. 22.

${ }_{611}$ AGAMBEN, Giorgio. We refugees. Tradução de Michael Rocke. Disponível em http://www.egs.edu/faculty/giorgio-agamben/articles/we-refugees/. Acessado em 2.6.2009.

${ }_{612}$ AGAMBEN, Giorgio. Means without end: notes on politics. Traducão Vincenzo Binetti e Cesare Casarino. Minneapólis: University of Minnesota Press, 2000, p. 20.
} 
para os apátridas falharam... Por outro lado, a naturalização também resultou em fracasso... quando foi preciso atender a pedidos de naturalização em massa... Era quase patético verificar quão impotentes eram os governos europeus... $\mathrm{O}$ apátrida, sem direito à residência e sem o direito de trabalhar, tinha, naturalmente, de viver em constante transgressão à lei. Estava sujeito a ir para a cadeia sem jamais cometer um crime. Mais do que isso, toda a hierarquia de valores existente nos países civilizados era invertida no seu caso."613

Para Arendt, aqueles direitos que, julgava-se, teriam o próprio homem como sua origem e seu objetivo último, fracassaram porque, no momento em que seres humanos deixavam de ter um governo próprio, não restava nenhuma autoridade para protegê-los e nenhuma instituição disposta a garanti-los. Por outro lado, quando uma entidade internacional se investia na autoridade não-governamental, seu fracasso se evidenciava não somente porque os governos se opunham abertamente, ou não, a essa usurpação de soberania, mas também porque as próprias nacionalidades interessadas deixavam de reconhecer uma garantia não-nacional.

Isto é, Agamben, relembrando que os primeiros campos na Europa eram tão somente espaços para controlar refugiados - e sua sucessão seriam os campos de concentração $^{614}$-, está seguindo Arendt ao afirmar que os direitos humanos não devem ser vistos como representação de um atributo onipresente, pré-jurídico e pré-político destinado a regular e limitar o poder estatal, mas, como elucida ARENDT, seja para as vítimas, seja para os opressores, seja para os espectadores, “... uma prova do idealismo fútil ou de tonta e leviana hipocresia" ${ }^{\prime 615}$. De acordo com PATRICIA OWENS, em texto de 2009 intitulado Beyond 'bare life': refugees and the 'right to have rights', foi de fato Arendt quem primeiro asseverou que o problema das clássicas declarações de direitos do homem erroneamente assumiram a existência de um ser biológico dotado de uma inerente

\footnotetext{
${ }^{613}$ ARENDT, Hannah. Origens do totalitarismo. Tradução de Roberto Raposo. São Paulo: Companhia das Letras, 1989, p. 312-324.

${ }^{614}$ AGAMBEN, Giorgio. Means without end: notes on politics. Traducão Vincenzo Binetti e Cesare Casarino. Minneapólis: University of Minnesota Press, 2000, p. 22.

${ }^{615}$ ARENDT, Hannah. Origens do totalitarismo. Tradução de Roberto Raposo. São Paulo: Companhia das Letras, 1989, p. 302.
} 
dignidade humana, quer dizer, de uma dignidade advinda da própria natureza humana ${ }^{616}$. FIONA JENKINS também identifica o problema, trazendo os atuais campos de refugiados na Austrália como exemplos do estado de exceção agambeniano:

"The detention camps of Australia hold people who may or may not be 'genuine' refugees. While their applications for refugee status are processed, men, women and children are detained in conditions that range from the uncomfortable to the unsafe and intolerable. That 'they', as the responsible Minister often puts it, are referred to by number not name, is just one dehumanising aspect of their situation. Minimal legal representation is sometimes available but rarely facilitated. Allegations of brutality and racism on the part of security officers are common but go largely unheeded by the government. Despite criticism by respected and authoritative international agencies following inspections of these camps, the Australian Government refuses to accept that there are reasonable alternatives to its detention policy. Indeed, it positively attempts to reap political benefits from its harsh policy towards people who are essentially assumed to be guilty until they can prove themselves innocent. And even at this point of proof, refugees are for the most part offered not citizenship, but the provisional accommodation of temporary protection visas."

Impende frisarmos neste ponto que, em que pesem as inspirações de Agamben na obra de Arendt quanto ao fracasso das autoridades internacionais para tratar de problemas de massa, há uma contraposição fundamental entre os dois pensamentos: para Agamben, o triunfo da vida nua produziu a dominação total, e não o contrário, como crê Arendt. De acordo com Agamben, nós já vivíamos num mundo de campos antes de a câmara de gás ser construída, ou seja, o regime nazista não foi algo inédito, mas somente a expressão par excellence da vida nua. O campo é o resultado da vida nua e não o inverso.

\footnotetext{
${ }^{616}$ OWENS, Patricia. Beyond 'bare life': refugees and the 'right to have rights'. Disponível em http://www.allacademic.com/one/isa/isa09/index.php?cmd=isa09_search\&offset $=0 \&$ limit $=5 \&$ multi_search_s earch_mode $=$ publication\&multi_search_publication_fulltext_mod $=$ fulltext\&textfield_submit $=$ true $\&$ search_

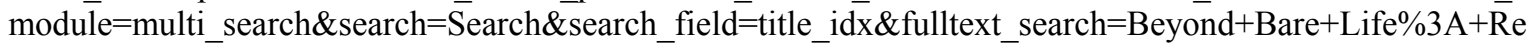
fugees+and + the $+\%$ E2\%80\%9CRight + to + Have+Rights $\%$ E $2 \% 80 \% 9 \mathrm{D}$. Acessado em 3.12.2009.

${ }^{617}$ JENKINS, Fiona. Op. cit., acessado em 3.8.2009.
} 
É nesse sentido que, parece-nos, a transferência do jurídico-político a entidades supranacionais - um sistema político global de freios e contrapesos para limitar e regular as forças globais, principalmente econômicas - não resolveria o paradigma do estado de exceção na visão de Agamben, porquanto a estrutura da vida nua permaneceria a mesma: seria somente uma nova versão da mesma estrutura. Daí a reivindicação agambeniana de pararmos de pensar na Declaração de 1789, assim como demais declarações supranacionais, como proclamações de valores eternos e metajurídicos, porquanto os direitos do homem ali inscritos são válidos somente enquanto cidadãos ${ }^{618}$, o que igualmente reflete o pensamento de $\operatorname{Arendt}^{619}$. Daí a dificuldade teórica em adequarmos um pensamento acerca dos direitos humanos no autor. Ná lógica dos Estados-nação, não haveria espaço para o homem por si só independente de uma cidadania advinda do nascimento:

"That there is no autonomous space within the political order of the nationstate for something like the pure man in himself is evident at least in the fact that, even in the best of cases, the status of the refugee is always considered a temporary condition that should lead either to naturalization or to repatriation. A permanent status of man in himself is inconceivable for the law of the nation-state." 620

Assim, o refugiado, enquanto figura limite nos moldes do homo sacer, traz à tona a crise da modernidade no momento em que expõe a quebra da identidade entre nascimento e nação, bem como entre homem e cidadão, deixando os Estados-nação impotentes: a Declaração falhou em sua missão, seja jurídica, seja política. Por essa razão, antes que novos campos de extermínio sejam inaugurados - o que já estaria acontecendo -, os Estados-nação devem questionar o próprio princípio da natividade e aquele que une

${ }^{618}$ Cf. Giorgio AGAMBEN. In: We refugees. Traduçao de Michael Rocke. Disponível em http://www.egs.edu/faculty/giorgio-agamben/articles/we-refugees/. Acessado em 2.6.2009.

619 "A calamidade dos que não têm direitos não decorre do fato de terem sido privados da vida, da liberdade ou da procura da felicidade, nem da igualdade perante a lei ou da liberdade de opinião - fórmulas que se destinavam a resolver problemas dentro de certas comunidades - mas do fato de já não pertencerem a qualquer comunidade. Sua situação angustiante não resulta do fato de não serem iguais perante a lei, mas sim de não existirem mais leis para eles; não de serem oprimidos, mas de não haver ninguém mais que se interesse por eles...”. ARENDT, Hannah. Origens do totalitarismo. Tradução de Roberto Raposo. São Paulo: Companhia das Letras, 1989, p. 329.

${ }^{620}$ AGAMBEN, Giorgio. We refugees. Traduçao de Michael Rocke. Disponível em http://www.egs.edu/faculty/giorgio-agamben/articles/we-refugees/. Acessado em 2.6.2009. 
Estado, nação e território ${ }^{621}$, rumo a um novo conceito de refugiado enquanto avant-garde, quer dizer, enquanto sujeitos pertencentes a um “... aterritorial or extraterritorial space in which all the residents of the European states (citizens and noncitizens) would be in a position of exodus or refuge, and the status of European would mean the citizen's being-inexodus (obviously also immobile). The European space would thus represent an unbridgeable gap between birth and nation, in which the old concept of people (which, as is well known, is always a minority) could again find a political sense by decisively opposing the concept of nation (which until now has unduly usurped it)"622. PATRICIA OWENS comenta o raciocínio de Agamben quanto ao refugiado:

"What is so special about the 'figure of the refugee'? Why does Agamben begin here and not with on of the other symbolic devices found across social and political theory, 'the worker', 'the subaltern', 'the multitude', or 'the terrorist'? There are four principal reasons for Agamben's choice. First, 'the one and only figure of the refugee' is said to more deeply expose the 'fiction' of national sovereignty and all associated legal and political categories such as 'people', 'public', 'human rights' and 'citizens'. Second, 'the refugee' can be represented as the paradigmatic site - and victim - of modern techniques of what Michael Foucault called 'governmentality', the organised practices and techniques used to produce, care for and/or dominate individual subjects. Third, and perhaps most originally, Agamben argues that refugees can be seen as the ultimate 'biopolitical' subjects, those who can be regulated and governed at the level of population in a permanent 'state of exception' outside the normal legal framework: the camp. There they are reduced to 'bare life', humans as animals in nature without political freedom. Finally, it is suggested that by fully comprehending the significance of refugees we may coutenance new ways of political belonging and the limits and possibilities of political community in the future. After the nation-state and its associated legal and political categories have been assigned to history the refugee will remain as 'perhaps the only thinkable figure'.,'623

\footnotetext{
${ }^{621}$ Cf. Giorgio AGAMBEN. In: Means without end: notes on politics. Traducão Vincenzo Binetti e Cesare Casarino. Minneapólis: University of Minnesota Press, 2000, p. 24.

622 AGAMBEN, Giorgio. We refugees. Traduçao de Michael Rocke. Disponível em http://www.egs.edu/faculty/giorgio-agamben/articles/we-refugees/. Acessado em 2.6.2009.

${ }^{623}$ OWENS, Patricia. Op. cit., acessado em 3.12.2009.
} 
A nova comunidade aterritorial será tratada em capítulo específico, bastando, por ora, termos em mente que a estrutura do campo nazista é a expressão física máxima do estado de exceção de acordo com Agamben, estrutura essa que perdura filosoficamente até hoje, como veremos abaixo.

Por outro lado, NEGRI dirá que a vida e a morte no campo nazista devem representar nada mais que um desastroso espetáculo do século XX: “Ao insistir no caráter trágico da modernidade, entretanto, não queremos, certamente, seguir os filósofos 'trágicos' da Europa, de Schopenhauer a Heidegger, que transformaram essas destruições reais em narrativas metafísicas sobre a negatividade do ser, como se essas tragédias reais fossem meramente uma ilusão, ou como se fossem nosso destino final!" ${ }^{24}$. Quer dizer, a objeção de Negri é no sentido de que os acontecimentos da guerra não devem representar nada além de sua revulsão. Fato é que, para Agamben, nada é mais perigoso que acreditarmos que os horrores já experimentados, relacionados ao nazismo ou não, sejam considerados somente um desvio do padrão do progresso e que a marcha da História está cegamente apontada ao bem estar. A questão para Agamben não é somente o retorno das formas bárbaras, mas também o desenvolvimento de novas formas sem precedentes, mais sangrentas e mais mortíferas, sempre sob as vestes do progresso enquanto catástrofe benjaminiana.

Agamben faz igual referencia aos USA Patriot Acts e subsequente military order autorizadoras da detenção indefinida de alienígenas suspeitos de atividades terroristas. Fazendo referencia à prisão de Guantanamo Bay e lançando uma analogia com os campos de concentração nazistas, Agamben anuncia que “... a novidade da 'ordem' do presidente Bush está em anular radicalmente todo o estatuto jurídico do indivíduo, produzindo, dessa forma, um ser juridicamente inominável e inclassificável" ${ }^{625}$. É fundamental notarmos, contudo, antes do desenvolvimento do raciocínio, que Agamben não compara as intenções políticas estadunidenses aos objetivos perseguidos na República de Weimar ou na Alemanha nazista, assim como Agamben não confronta a força física utilizada nesses dois

\footnotetext{
${ }^{624}$ HARDT, Michel; NEGRI, Antonio. Império. Traduçao de Berilo Vargas, 8 ed. Rio de Janeiro: Record, 2006, p. 65.

${ }^{625}$ Cf. Giorgio AGAMBEN. In: Estado de exceção. Tradução de Iraci D. Poleti. São Paulo: Boitempo, 2004, p. 14.
} 
momentos: trata-se somente de uma mesma relação jurídica no seu entender. OLGÁRIA MATos também traça esse paralelo:

"Analogamente ao que ocorreu na República de Weimar, que, com sua Constituição, viveu em estado e exceção, o estado de guerra permanente dos Estados Unidos da América do Norte encontra-se em sua Carta Magna em nome das razões de Estado, tal como no século barroco teológico-político. O filósofo italiano Domenico Losurdo trata da Constituição da Filadélfia de 1787, sucedâneo das Sagradas Escrituras. Ela sancionava um verdadeiro golpe de Estado, construída para barrar e extirpar a agitação democrática radical que se seguira à Guerra de Independência... Ao longo do tempo esse evangelho passou a ser, para os estadunidenses, uma das mídias a serviço do narcisismo, não de Deus, mas de heróis guerreiros. Nos termo de Horkheimer e de Adorno, a sociedade estadunidense é a realização mais perfeita da autoconservação (luta pela manutenção da vida material pela dominação do outro) e da razão instrumental (utilitária, pragmática, imediatista, antiintelectual e anticontemplativa; instrumento de poder e não de desenvolvimento para fins de emancipação)."

O próprio Agamben faz a mesma equiparação: “Aber ich sprach ja von den Gefangenen in Guantánamo, und deren Situation ist juristisch gesehen in der Tat vergleichbar mit derjenigen in den Nazi-Lagern. Die detainees von Guantánamo haben nicht den Status von Kriegsgefangenen, sie haben überhaupt keinen juristischen Status mehr. Sie unterliegen einer nur noch faktischen Herrschaft, sie haben keine rechtliche Existenz. In den Nazi-Lagern mussten die Juden erst vollständig 'denationalisiert' und aller nach Nürnberg noch verbliebenen staatsbürgerlichen Rechte beraubt werden, danach erst waren sie ebenfalls als Rechtssubjekte ausgelöscht"627.

\footnotetext{
${ }^{626}$ MATOS, Olgária. Op. cit., p. 46.

${ }^{627}$ AGAMBEN, Giorgio. Ein gespräch mit Giorgio Agamben: das leben, ein kunstwerk ohne autor: der Ausnahmezustand, die verwaltung der unordnung und das private leben. Disponível em www.suddeutschezeitung.com, edição de 6.4.2004. Versão em inglês disponível em German Law Journal, n. 5, special edition. Disponível em http://www.germanlawjournal.com/article.php?id=437.
} 
A doutrina da segurança nacional é, assim, utilizada para manter a hegemonia internacional estadunidense, utilizando os poderes de exceção sem controle algum ${ }^{628}$. A homogeneização que ocorre nos Estados Unidos da América sob a cultura do pânico é um bom exemplo do estado de exceção: "Tudo ocorre como se a Constituição tivesse sido concebida tendo em mente o estado de exceção, e a energia republicana não passasse de um estado de exceção represado. E o 11 de setembro foi 'providencial' para instaurar a 'cultura do pânico' e a expansão territorial a partir da Constituição americana de autolouvação evangélica... Os Estados Unidos da América do Norte, em guerra permanente, estariam acelerando a história na direção de um final glorioso, da mesma maneira que a limpeza dos hereges simplifica o caminho do triunfo da verdade redentora. Quando se acredita na posse da verdade, não a impor àqueles incapazes de vê-la é um lamentável retardamento do final feliz. Sobre essa base se constrói boa parte da paixão política norte-americana. Só o Ocidente pode aspirar ao paraíso, só a racionalidade técnica nos dará o bem-estar definitivo. A ideologia norte-americana realiza com perfeição o Estado 'totalitário' em seu sonho de unir na terra o poder e o absoluto, o teológico e o político" ${ }^{\text {629. }}$.

VERA KARAM DE ChUEIRI ${ }^{630}$ entende que "a experiência do campo de concentração é a da suspensão temporal de todo o direito, em relação a um espaço determinado e permanente que resta, assim, fora do estado (normal) de direito. Não obstante o campo de concentração possa ser territorialmente determinado (o campo de Dachau, por exemplo), sobre tal território não impera a ordem jurídica vigente (como de fato não operou), vale dizer, ele se localiza fora da ordem, do direito vigente".

Daí a afirmação de Agamben de que "... what is being excluded in the camp is captured outside, that is, it is included by virtue of its very exclusion. Thus, what is being captured under the rule of law is first of all the very state of exception. In other words, if sovereign Power is founded on the ability to decide on the state of exception, the camp is

\footnotetext{
${ }^{628}$ Cf. BERCOVICI, Gilberto. In: Soberania e constituição: para uma crítica do constitucionalismo. São Paulo: Quartier Latin, 2008, p. 329.

${ }^{629}$ MATOS, Olgária. Op. cit., p. 46.

${ }^{630}$ CHUERI, Vera Karam de. Op. cit., p. 98.
} 
the structure in which the state of exception is permanently realized" ${ }^{\prime 631}$. Nesse mesmíssimo sentido a interpretação de STEVEN DECAROLI:

"In other words, the inhabitant of the camp, those in exile, or those who have otherwise been removed from the proper jurisdiction of the law, are made homo sacer precisely because, despite being placed outside the law and its protection, they retain a (extra-legal) relationship with the law by having been excluded from it." 632

SETH J. HAWKINS soube muito bem capturar essa condição de anomia ao tratar de casos práticos travados perante o Judiciário estadunidense, notadamente no caso Rasul $v$. Bush, no qual o federal District Court for the District of Columbia “... held that suspected terrorists detained at the U.S. Naval Base in Guantanamo Bay, Cuba (Guantanamo), could not petition federal courts for a writ of habeas corpus because Guantanamo was outside the sovereign territory in the United States" $" 633$.

Ao longo de seu texto, esse autor explica que o caso Rasul v. Bush tratava da vida (nua) de 20 detentos em Guantanamo, separados em dois grupos, em razão da ordem proferida pelo então Presidente Bush para "use all necessary and appropriate force" contra os responsáveis por atos terroristas.

Enquanto um grupo (Rasul) impetrou habeas corpus requerendo sua imediata liberdade e o fim de todos os interrogatórios, o outro grupo (Odah) somente requereu o direito de ver a família, de ser informado de seus pretensos crimes e, por fim, de consultar advogado. Em ambas as pretensões, o tribunal estadunidense entendeu que “... aliens held outside the sovereign territory of the United States [cannot] use the courts of the United States to pursue claims brought under the U.S. Constitution. " ${ }^{, 635}$ Em outras palavras, sob o

\footnotetext{
631 AGAMBEN, Giorgio. Means without end: notes on politics. Traducão Vincenzo Binetti e Cesare Casarino. Minneapólis: University of Minnesota Press, 2000, p. 38.

${ }^{632}$ DECAROLI, Stevens. Op. cit., p. 52.

${ }^{63}$ HAWKINS, Seth J. Up Guantanamo without a paddle: waves of Afghan detainees drown in America's great habeas loophole. In: Saint Louis University Law Journal. Vol. 47, No. 4, Summer 2003, p. 1243.

634 Joint Resolution, Authorization for Use of Military Force, S.J. Res. 23. Disponível em HTTP://news.findlaw.com/cnn/docs/terrorism/sjres23.enr.html.

${ }^{635}$ HAWKINS, Seth J. Op. cit., p. 1244.
} 
argumento de que os Estados Unidos da América, muito embora possuíssem jurisdição e controle, não eram soberanos em Guantanamo, todas as pretensões foram indeferidas.

O tribunal baseou sua assertiva no argumento de que a base militar de Guantanamo Bay fora simplesmente arrendada contratualmente ${ }^{636}$ pelos Estados Unidos da América em 1903 e que, muito embora os Estados Unidos da América tivessem complete jurisdiction and control, não haveria como se tratar de soberania ${ }^{637}$ in casu. Hawkins esclarece que essa cláusula é inerente a diversos contratos relacionados a bases militares estadunidenses e que a interpretação teleológica realmente levaria à conclusão de que soberania e jurisdição/controle - com relação aos militares americanos, frise-se - não se confundem e, por fim, que os Estados Unidos da América nunca pretenderam ter soberania nesses territórios. Muito embora o julgamento acima citado tenha sido revertido pelo Supremo Tribunal estadunidense, como noticia em texto posterior TOMMASO EDOARDO FrosinI ${ }^{638}$, Hawkins indaga: "Are the political boundaries of 100 years ago still appropriate?"

Reduzidos a essa condição, os ocupantes do campo - sem qualquer mediação tradicional de inclusão política, normalmente expressas na forma de direitos - encontramse numa condição político-jurídica de compreensível abandono. Não são prisioneiros, nem acusados, apenas detentos de fato: os indivíduos são objeto de uma pura dominação, de uma detenção indeterminada não só no sentido temporal, mas também quanto à sua própria natureza, porque totalmente fora da lei (ex-capere) e do controle judiciário:

"Os talibãs capturados no Afeganistão, além de não gozarem do estatuto de POW [prisioneiro de guerra] de acordo com a Convenção de Genebra, tampouco gozam daquele de acusado segundo as leis norte-americanas. Nem prisioneiros nem acusados, mas apenas detainees... A única comparação

\footnotetext{
${ }^{636}$ A seguinte era a cláusula tutelando a matéria: "While on the one hand the United States recognizes the continuance of the ultimate sovereignty of the Republic of Cuba over the above described areas of land and water, on the other hand the Republic of Cuba consents that during the period of occupation by the United States of said areas under the terms of this agreement the United States shall exercise complete jurisdiction and control over and within said areas..."

${ }^{637}$ É de se notar que os requerentes homo sacer arguiram que os Estados Unidos da América exerciam soberania de facto sob a base naval.

638 "En la sentencia Rasul, el Tribunal dispone para todos los detenidos, sean éstos extranjeros o estadounidenses, el derecho a recurrir ante un Tribunal federal de Estados Unidos con un writ of habeas corpus. De este modo, el Tribunal desmantela la decisión de la D.C.Court of Appeals, y rechaza las posiciones del Gobierno, que apelaban al precedente de Johnson v. Eisentrager, confirmando la extraterritorialidad de la base de Guantánamo”. In: El estado de derecho se há detenido em Guantánamo. In: Revista Española de Derecho Constitucional. Año 26, núm. 76, enero/abril 2006, p. 58.
} 
possível é com a situação jurídica dos judeus nos Lager nazistas: juntamente com a cidadania, haviam perdido toda identidade jurídica, mas conservaram pelo menos a identidade de judeus." 639

Assim, para Slavoj ZiZEK, nada está a impedir um paralelo entre o estado de aniquilação do homo sacer e o extermínio nazista, onde a matança não resultava num crime ${ }^{640}$. O campo é, para Agamben, um espaço absolutamente biopolítico em que o poder é exercido não contra sujeitos jurídicos, mas corpos biológicos. Seria, na verdade, um espaço no qual a soberania existe, mas a lei não (entenda-se suspensa); um território onde as ações não são legais, nem ilegais ${ }^{641}$ (não/nem):

“... ele á um pedaço de território que é colocado fora do ordenamento jurídico normal, mas não é, por causa disso, simplesmente um espaço externo. Aquilo que nele é excluído é, segundo o significado etimológico do termo exceção, capturado fora, incluindo através da sua própria exclusão." ${ }^{642}$

É nesse sentido que JENNY EDKINS conclui que o extermínio no campo não é uma questão "of killing",643, mas a produção do não-humano: coloca-se em jogo os limites do humano e de não-humano, do ser vivo e do ser que fala. Isto é, o que era um valor passa a ser um desvalor. Essa passagem pode ser notada em outras figuras inquietantes no trabalho de Agamben e inerentes ao campo: a testemunha e o muçulmano, ambas tratadas na obra $O$ que resta de Auschwitz.

Em latim, há dois termos para representar a testemunha: o primeiro, testis, significa etimologicamente aquele que se põe como terceiro (terstis) em um processo entre dois contendores; o segundo, superstes, indica aquele que viveu algo, atravessou até o final um evento e pode, portanto, dar testemunho disso ${ }^{644}$. Analisando os textos de Primo Levi, com quem Agamben teve contato pessoal, como uma perfeita testemunha supérstite, Agamben

\footnotetext{
${ }^{639}$ AGAMBEN, Giorgio. Estado de exceção. Tradução de Iraci D. Poleti. São Paulo: Boitempo, 2004, p. 14.

${ }^{640}$ In: Violence. New York: Picador, 2008, p. 199.

${ }^{641}$ Cf. Steven DeCaroli. Op. cit., p. 53.

${ }^{642}$ AGAMBEN, Giorgio. Homo sacer: o poder soberano e a vida nua I. Tradução de Henrique Burigo. Belo Horizonte: Editora UFMG, 2002, p. 176.

643 In: Whatever Politics. In: CALARCO, Mattherw; DECAROLI, Stevens (ed.). Giorgio Agamben: sovereignty and life. Stanford, California: Stanford University Press, 2007, p. 79.

${ }^{644}$ Cf. Giorgio AGAMBEN. In: O que resta de Auschwitz: o arquivo e a testemunha. Tradução de Selvino J. Assmann. São Paulo: Boitempo, 2008, p. 27 e 35.
} 
qualifica a testemunha como aquele que, por prevaricação, habilidade ou sorte, não tocou o fundo, aquele que teve um privilégio em relação ao detento comum levado ao extermínio (o muçulmano). A testemunha é aquele que narra as coisas vistas de perto em nome de terceiros, muito embora essa delegação seja em seu ver sem sentido, porquanto “... os submersos nada têm a dizer, nem têm instruções ou memórias a transmitir" ${ }^{645}$.

Trata-se de uma relação interessante: se somente o muçulmano viveu a experiência até o seu limite, essa experiência nunca poderá ser dita, porquanto não se pode testemunhar de dentro da morte, assim como ninguém volta para contar sua própria morte. Por derradeiro, o verdadeiro testemunho nunca poderá ser dito, assim como a testemunha narra sempre o intestemunhável.

Por outro lado, o intestemunhável tem nome: muçulmano ${ }^{646}$, aquele que tocou o fundo, aquele que, pela desnutrição e suas consequências físicas e psíquicas é indiferente a tudo que acontecia a seu redor, tal como o autista, excluído de qualquer relação com seu meio ambiente. Um homem-múmia, um morto-vivo, um cadáver ambulante, o homo sacer. O muçulmano é o próprio conceito-limite entre vida e morte, entre o homem e o nãohomem, porquanto ele se apresenta como o não-vivo - o ser cuja vida não é realmente vida - e, ao mesmo tempo, como aquele cuja morte não pode ser chamada de morte, pois mera fabricação de cadáver.

O contraste entre o muçulmano e a testemunha dá-se da seguinte maneira, consoante lição de DOMINICK LACAPRA com base na obra O que resta de Auschwitz:

"The Muselmann is one who cannot bear witness for himself or herself and hence needs to be supplemented by the witness, who nonetheless is

\footnotetext{
${ }^{645}$ AGAMBEN, Giorgio. O que resta de Auschwitz: o arquivo e a testemunha. Tradução de Selvino J. Assmann. São Paulo: Boitempo, 2008, p. 43.

${ }^{646}$ A origem do termo essencialmente utilizado em Auschwitz, para Agamben, não é certa, até mesmo porque cada campo nazista tinha a sua própria expressão: gamel (gamela), kretiner (idiotas), krüppel (aleijados), schwimmer (quem fica boiando fingindo-se de morto), kamele (camelos), müde scheichs (imbecis). Segundo Agamben, a teoria mais provável é a de que muçulmano era assim chamado porque, visto de longe em sua agonia (com o corpo recolhido, tal como um homem-concha), dava-se a impressão de um árabe em oração. Cf. Giorgio AGAMBEN. In: O que resta de Auschwitz: o arquivo e a testemunha. Tradução de Selvino J. Assmann. São Paulo: Boitempo, 2008, p. 49-53.
} 
paradoxically forced to bear witness to the (Muselmann) impossibility of witnessing. $" 647$

CATHERINE MiLls traz uma excelente explicação da conceituação do muselmann em Agamben:

"As the threshold between the human and the inhuman, the Muselmann does not simply mark the limit beyond which the human is no longer human. Agamben argues that such a stance would merely repeat the experiment of Auschwitz, in which the Muselmann is put outside of the limits of the human and the moral status that attends that categorization. Instead, the Muselmann indicates a more fundamental lack of distinction between the human and the inhuman, in which it is impossible definitively to separate one from the other, and which calls into question the moral distinctions that rest on this designation. The key question that arises for Agamben, then, is whether there is a 'humanity to the human' over and above biologically belonging to the species, and it is in reflecting on this question that Agamben develops his account on ethics." 648

No entanto, a vida que reside no campo não é, na filosofia agambeniana, uma nova formação histórica, em que pese respeitável opinião divergente ${ }^{649}$. Em contraste a Foucault, para quem o biopoder representa uma mudança de paradigma, mas se aproximando de Adorno, para quem a nossa era é a era do campo de concentração, Agamben sustenta que a inclusão do muçulmano - enquanto vida nua - na ordem política é absolutamente anciã e o que torna a atual situação perceptível é o grau atingido pelo reinado da vida nua para se coincidir com a própria política. CATHERINE MILLS capta esse trazer à luz na divergência entre Zygmunt Bauman e Agamben:

\footnotetext{
${ }^{647}$ LACAPRA, Dominick. Op. cit., p. 136.

${ }^{648}$ MILLS, Catherine. The philosophy of Agamben. McGill-Queen's University Press, 2008, p. 82.

${ }^{649}$ Paulo Roberto dos Santos CABRAL, ao interpretar a obra de Agamben, declina que "O campo, assim, é o espaço político desse periodo de transição do século XX para o XXI, em que a organização planetária marca uma localização sem ordenamento que não está restrita ao âmbito internacional, mas se mostra de maneira clara no interior dos próprios Estados, a exemplo da situação dos excluídos, moradoras das favelas do Brasil". In: Teoria constitucional e exceção permanente: uma categoria para a teoria constitucional do século XXI. Curitiba: Jaruá, 2009, p. 147.
} 
"For Bauman, the Holocaust was a product of bureaucratic rationality and its unchecked application to social organization, but he is explicit that this does not mean that the Holocaust was in any way determined by instrumental reason or an inexorable result of it. For him, while modern civilization was the necessary condition of the Holocaust, it was by no means its sufficient condition. In contrast, for Agamben, the Nazi genocide was indicative of a hidden logic intrinsic to Western politics, and the paroxysms of World War II merely brought this logics to light in an unprecedent way." 650

Para Agamben, o campo é o evento que marca de modo decisivo o próprio espaço político da modernidade. Ele se produz no ponto em que o sistema político do Estadonação moderno, que se fundava sobre o nexo funcional entre uma determinada localização (o território) e um determinado ordenamento (o Estado), medido por regras automáticas de inscrição da vida (o nascimento ou nação), entra em crise duradoura, e o Estado decide assumir diretamente entre as próprias funções os cuidados da vida biológica da nação ${ }^{651}$.

O sistema político não ordena mais formas de vida e normas jurídicas em um espaço determinado, mas contém em seu interior uma localização deslocante que o excede, na qual toda forma de vida e toda norma podem virtualmente ser capturadas. Quer dizer, o poder soberano em Agamben sempre colocou a vida biológica em seu centro, mas somente agora o estado moderno explicitou esse caráter, qualificando a distinção entre humano e cidadão, entre fato e direito, todos indistinguíveis. O que é revelado nessa conclusão e que reage à primazia do campo soberano é que a lei, ao lado do amplo rol de instituições legais que a administram, forma uma secular cobertura que ao mesmo tempo legitima a autoridade soberana e obscurece a antiga relação entre autoridade e ordem pré-legal de seu território jurisdicional.

Ademais, é importante notarmos a distinção entre o direito carcerário interno ao processo de normalização nos trabalhos de Foucault e a lógica do campo ora exposta. O

\footnotetext{
${ }^{650}$ MILLS, Catherine. The philosophy of Agamben. McGill-Queen's University Press, 2008, p. 84.

${ }^{651}$ Cf. Giorgio AGAMBEN. In: Homo sacer: o poder soberano e a vida nua I. Tradução de Henrique Burigo. Belo Horizonte: Editora UFMG, 2002, p. 181.
} 
campo agambeniano deve ser filosoficamente distinto do espaço de reclusão foucaultiano, até mesmo porque não advém da lei penal ${ }^{652}$ :

"Não é o cárcere, mas o campo, na realidade, o espaço que corresponde a esta estrutura originária do nómos. Isto mostra-se, ademais, no fato de que enquanto o direito carcerário não está fora do ordenamento normal, mas constitui apenas um âmbito particular do direito penal, a constelação jurídica que orienta o campo é, como veremos, a lei marcial ou o estado de sítio. Por isto não é possível inscrever a análise do campo na trilha aberta pelos trabalhos de Foucault, da História da loucura a Vigiar e punir. O campo, como espaço absoluto de exceção, é topologicamente distinto de um simples espaço de reclusão."653

O campo, portanto, foi de alguma forma sempre o âmago da política e, como tal, inseparável do exercício da soberania. Colocado de outra forma, a vida nua que existe no estado de exceção constitui o campo de obediência que permite ao maquinário jurídico do Estado funcionar. Por isso, “... o campo é o próprio paradigma do espaço político no ponto em que a politica torna-se biopolítica e o homo sacer se confunde virtualmente com o cidadão" ${ }^{\circ 54}$ (Per questo il campo è il paradigma stesso dello spazio politico nel punto in cui la politica diventa biopolitica e l'homo sacer si confonde virtualmente col cittadino).

Assim, forçoso que os exemplos de Agamben não se resumam aos campos dos Novecentos, mas em figuras do dia a dia da democracia hodierna. Exemplificativamente, essa conceituação é utilizada como ferramenta para compreensão de fenômenos tão diversificados como o status internacional dos refugiados, homens-bomba suicidas e, até mesmo, a condição de pobreza e/ou doenças sofridas (HIV) no Brasil, entre outros. Agamben também alude ao caso Karen Quinlan, "a garota americana que entrou em coma profundo e foi mantida viva por anos através de respiração e nutrição artificiais" ${ }^{655}$, que

\footnotetext{
${ }^{652}$ Cf. Giorgio AGAMBEN. In: Means without end: notes on politics. Traducão Vincenzo Binetti e Cesare Casarino. Minneapólis: University of Minnesota Press, 2000, p. 38-39.

${ }^{653}$ AGAMBEN, Giorgio. Homo sacer: o poder soberano e a vida nua I. Tradução de Henrique Burigo. Belo Horizonte: Editora UFMG, 2002, p. 27.

${ }^{654}$ AGAMBEN, Giorgio. Homo sacer: o poder soberano e a vida nua I. Tradução de Henrique Burigo. Belo Horizonte: Editora UFMG, 2002, p. 178.

${ }^{655}$ AGAMBEN, Giorgio. Homo sacer: o poder soberano e a vida nua I. Tradução de Henrique Burigo. Belo Horizonte: Editora UFMG, 2002, p. 170.
} 
recomeçou a respirar naturalmente, bem como à anencefalia, à noção de além-comatoso ${ }^{656}$ e à própria automedicação/experimentação na ciência; o corpo como laboratório experimental que já não é privado, justamente por ser um laboratório, nem público, porquanto ainda é seu corpo biológico. A figura da eutanásia ${ }^{657}$ é igualmente levantada como exemplo da vida que pode ser morta sem que se cometa crime, de modo que “... $a$ vida nua não está mais confinada a um lugar particular ou em uma categoria definida, mas habita o corpo biológico de cada ser vivente" ${ }^{958}$. De acordo com Agamben:

'O conceito de 'vida sem valor' (ou 'indigna de ser vivida') aplica-se antes de tudo aos indivíduos que devem ser considerados 'incuravelmente perdidos' em seguida a uma doença ou ferimento e que, em plena consciência de sua condição, desejam absolutamente a "liberação",,659

Agamben reflete que ainda mais problemática é a condição dos “... idiotas incuráveis, tanto no caso de terem nascido assim, como no caso - por exemplo, os doentes de paralisia progressiva - de o terem se tornado na última fase de suas vidas" ${ }^{\text {660 }}$. Citando a sucessão de fatos na Alemanha nazista ${ }^{661}$, Agamben conclui que "Não resta outra

\footnotetext{
${ }^{656} \mathrm{Em}$ que “... em jogo estava nada mais nada menos do que a redefinição da morte”: “... a sobrevivência do além-comatoso, de fato, cessava automaticamente logo que os tratamentos de reanimação eram interrompidos: à completa ausência de toda reação aos estímulos que caracterizava o coma profundo seguia-se então o imediato colapso cardio-vascular e a cessação de todo movimento respiratório". In: AGAMBEN, Giorgio. Homo sacer: o poder soberano e a vida nua I. Tradução de Henrique Burigo. Belo Horizonte: Editora UFMG, 2002, p. 167.

${ }^{657}$ Muito embora ele ressalve que "Não é nossa intenção assumir aqui uma posição sobre o dificil problema ético da eutanásia, que divide ainda hoje as opiniões e, em alguns países, ocupa um lugar considerável no debate da mídia, nem nos interessa a radicalidade com que Binding se posiciona a favor de sua admissibilidade generalizada. Mais interessante, em nossa perspectiva, é o fato de que à soberania do homem vivente sobre a sua vida corresponda imediatamente a fixação de um limiar além do qual a vida cessa de ter valor jurídico e pode, portanto, ser morta sem que se cometa homicídio". AGAMBEN, Giorgio. Homo sacer: o poder soberano e a vida nua I. Tradução de Henrique Burigo. Belo Horizonte: Editora UFMG, 2002, p. 146.

${ }^{658}$ AGAMBEN, Giorgio. Homo sacer: o poder soberano e a vida nua I. Tradução de Henrique Burigo. Belo Horizonte: Editora UFMG, 2002, p. 146.

${ }^{659}$ AGAMBEN, Giorgio. Homo sacer: o poder soberano e a vida nua I. Tradução de Henrique Burigo. Belo Horizonte: Editora UFMG, 2002, p. 145.

${ }^{660}$ AGAMBEN, Giorgio. Homo sacer: o poder soberano e a vida nua I. Tradução de Henrique Burigo. Belo Horizonte: Editora UFMG, 2002, p. 145.

661 “... o problema da eutanásia é um problema peculiarmente moderno, que o nazismo, como primeiro Estado radicalmente biopolitico, não podia deixar de colocar; e, por isto, certas aparentes loucuras e contradições do Euthanasie-Programm explicam-se apenas no contexto biopolítico em que ele se situava... $O$ fato é que o Reich nacional-socialista assinala o momento em que a integração entre medicina e política, que é uma das características essenciais da biopolítica moderna, começa a assumir a sua forma consumada. Isto implica que a decisão soberana sobre a vida de desloque, de motivações e âmbitos estritamente políticos, para um terreno mais ambiguo, no qual o médico e o soberano parecem trocar seus papéis". AGAMBEN, Giorgio. Homo sacer: o poder soberano e a vida nua I. Tradução de Henrique Burigo. Belo Horizonte: Editora UFMG, 2002, p. 149-150
} 
explicação além daquela segundo a qual, sob a aparência de um problema humanitário, no programa estivesse em questão o exercício, no horizonte da nova vocação biopolítica do estado nacional-socialista, do poder soberano de decidir sobre a vida nua" ${ }^{\prime 662}$.

Nesse sentido, a vida indigna de ser vivida não seria um conceito ético, mas sobretudo um conceito político no qual está em questão a extrema metamorfose da vida matável e insacrificável do homo sacer sobre a qual se baseia o poder soberano:

"Se ao soberano, na medida em que decide sobre o estado de exceção, compete em qualquer tempo o poder de decidir qual vida possa ser morta sem que se cometa homicídio, na idade da biopolítica este poder tende a emancipar-se do estado de exceção, transformando-se em poder de decidir sobre o ponto em que a vida cessa de ser politicamente relevante., ${ }^{, 663}$

Todas essas figuras não refletem a vida, nem a morte, mas tão somente a lógica do biopoder pela produção de uma sobrevivência modulável. Agora podemos entender, com mais razão, porque Agamben, como adiantado no início deste trabalho, acredita que a estrutura de nosso tempo não é um fazer morrer e deixar viver da soberania clássica ou um fazer viver e deixar morrer da biopolítica foucaultiana, mas um já não fazer morrer, nem fazer viver, mas fazer sobreviver. Auschwitz está entre nós.

${ }^{662}$ AGAMBEN, Giorgio. Homo sacer: o poder soberano e a vida nua I. Tradução de Henrique Burigo. Belo Horizonte: Editora UFMG, 2002, p. 148.

${ }^{663}$ AGAMBEN, Giorgio. Homo sacer: o poder soberano e a vida nua I. Tradução de Henrique Burigo. Belo Horizonte: Editora UFMG, 2002, p. 148-149. 


\section{CAPÍTULO 3}

\section{A VIDA-FELIZ}

$\mathrm{Na}$ introdução de Homo sacer, Agamben reflete que, somente quando da conscientização das sugestões de Foucault e Benjamin quanto à biopolítica e à emergência do stato di eccezione no núcleo da democracia, estaremos de fato interrogando a relação entre vida nua e política que governa secretamente as ideologias hodiernas. Somente dessa maneira restituiríamos o pensamento à sua vocação política ${ }^{664}$, quer dizer, somente ao darmos conta das figuras que imperam na democracia contemporânea, estaremos preparados para discutir uma nova política, ou resgatá-la de sua atual obscuridade.

Nos últimos parágrafos de Homo sacer, Agamben sugere que a resolução do nexo entre lei e vida só pode ser possível por meio da discussão de uma nova forma-di-vita, que não permite a separação entre bios e zoé. Ao invés disso, elas seriam unificadas numa absoluta imanência de si mesma, de maneira a apontar o caminho da superação do banimento soberano. De outra forma, toda teoria e toda prática ficarão aprisionadas e imóveis, e todo exercício da cidadania somente se dará por meio do sangue e da morte ou, ainda, por meio da perfeita falta de sentido ao qual a sociedade do espetáculo midiático a condena. Como bem explicam Susana SCRAmim e Vinícius NiCASTRo HonesKo:

“... uma comunidade humana na qual a política possa estar radicada nessa comdivisão da própria existência - uma comunidade que vem, como lembrava Agamben já em 1990 em livro homônimo - não é uma comunidade em cuja política está a divisão e a partilha de uma ou outra classe de fundação comunitária (um local de nascimento, uma língua, uma cor etc.); tampouco uma comunidade que se paute pela simples ausência genérica de condições de sua fundação (como uma comunidade negativa), mas uma comunidade do ser tal qual é (quodlibet), cuja única diversão e partilha seja puramente existencial, isto é, uma comunidade em que a política seja a amizade."665

\footnotetext{
${ }^{664}$ Cf. Giorgio AGAMBEN. In: Homo sacer: o poder soberano e a vida nua I. Tradução de Henrique Burigo. Belo Horizonte: Editora UFMG, 2002, p. 12.

${ }^{665}$ SCRAMIM, Susana; HONESKO, Vinícius Nicastro. In: Introdução a AGAMBEN, Giorgio. O que é contemporâneo? e outros ensaios. Tradução Vinícius Nicastro Honesko. Chapecó: Argos, 2009, p. 16.
} 
Agamben busca nada menos que uma redefinição filosófica da vida que não mais seja balizada na separação entre vida natural e vida política - e da esclusione inclusiva da vida nua - e que, na verdade, esteja além de qualquer forma de relação, ou seja, fundada unicamente em si mesma. A inauguração dessa vida-feliz ${ }^{666}$, que não pode isolar bios e zoé e que despreza qualquer ligação com a soberania e com o direito, permitiria a superação da lei em vigor sem significância acima analisada: a vivência da vida além do alcance da lei. O problema fundado pelo estado de exceção e a captura da nuda vita pela soberania seriam resolvidas por essa inauguração.

Trata-se de uma política que não pode sequer deter uma forma de identidade ou movimento social político. De outra forma, ao traçar linhas de identidade ou contemplar distinções haveria igualmente uma forma de poder soberano, é dizer, seria parte da mesma lógica que hoje nos aprisiona: "Poiché il fatto nuovo della politica che viene è che essa non sarà più lotta per la conquista o il controllo dello stato, ma lotta fra lo stato e il non-stato (l'umanità)" ${ }^{\prime 667}$. Há de ser encontrada uma aterritorialidade para que as cidades redescubram sua vocação de cidades do mundo por meio de uma recíproca relação extraterritorial $^{668} \mathrm{e}$, dessa maneira, todos possamos nos tornar os refugiados avant-garde livres da tríade Estado/nação/território - de que tratam Arendt e Agamben.

Agamben pretende mostrar o direito em sua não-relação com a vida e a vida em sua não-relação com o direito, abrindo um espaço para o resgate de uma ação humana, inclusive de crença, esperança e amor - não enquanto sentimentos, mas agir social -, que teriam sido todos contaminados pelo direito. Ele busca uma nova categoria não mais dependente, por exemplo, da noção de transgressão da norma ou de novas normas, mas simplesmente da anulação do potencial normativo da norma, anulação da referência à norma. Para Vera KARAM DE CHUEIRI:

"Neste limiar em que vivemos, no qual a ação humana sem relação com o direito está diante de uma norma sem relação com a vida, não nos cabe

\footnotetext{
${ }^{666}$ Cf. Giorgio AGAMBEN. In: Means without end: notes on politics. Traducão Vincenzo Binetti e Cesare Casarino. Minneapólis: University of Minnesota Press, 2000, p. 114.

${ }^{667}$ AGAMBEN, Giorgio. La comunità che viene. Turim: Bollati Boringghieri, 2001, p. 67.

${ }^{668}$ Cf. Giorgio AGAMBEN. Means without end: notes on politics. Traducão Vincenzo Binetti e Cesare Casarino. Minneapólis: University of Minnesota Press, 2000, p. 25.
} 
reivindicar a volta ao Estado de direito, já que os próprios conceitos de Estado e de direito estão em questão. Cabe, pois, no limite da tensão provocada pelo Estado de exceção pensar no que articula a vida e direito, anomia e nomos, auctoritas e potestas. Desmascarar tal articulação não restitui o Estado à sua condição original, mas abre possibilidades para uma ação política comprometida e, neste sentido, crítica." ${ }^{669}$

Assim, seguindo o pensamento de Benjamin à busca de um verdadeiro estado de exceção, e não o fictício em que hoje vivemos, Agamben concorda que é necessária uma nova forma de pensar, além da razão instrumental, uma comunidade política que não pressuponha o poder soberano e se liberte do capitalismo consumista. Uma tarefa que não nos parece fácil, até mesmo porque o próprio Agamben, em Profanações, explana que o capitalismo globalizado, em sua fase extrema hoje vigorante, sonha com e aponta a todo momento para o improfanável. Como sair do labirinto da soberania e abandonar o direito e, mais inquietante, rumo a o quê? Como, então, atender o chamado agambeniano para uma nova política e uma comunidade que vem? $?^{670}$

"O que está realmente em questão é, na verdade, a possibilidade de uma ação humana que se situe fora de toda relação com o direito, ação que não ponha, que não execute ou que não transgrida simplesmente o direito... $\mathrm{E}$ talvez 'política' seja o nome desta dimensão que se abre a partir de tal perspectiva, o nome do livre uso do mundo... Por isso tenho trabalhado recentemente sobre o conceito de 'profanação' que, no direito romano, indicava o ato por meio do qual o que havia sido separado na esfera da religião e do sagrado voltava a ser restituído ao livre uso do homem." ${ }^{671}$

\footnotetext{
${ }^{669}$ Cf. CHUERI, Vera Karam de. Agamben e o estado de exceção como zona de indeterminação entre o político e o jurídico. In: Crítica da Modernidade: diálogos com o direito. Florianópólis: Fundação Boiteux, 2005, p. 104.

${ }^{670}$ Para Selvino J. ASSMANN, "Quem lê os livros de Giorgio Agamben se sente interessado em saber mais e melhor o que para ele é, ou são, 'o ser que vem', 'o ser humano que vem', 'a política que vem', 'a ética que vem', 'a comunidade que vem'. Tudo o que vem parece ter a ver com o 'messias que vem'. Cá e lá parece haver o prenúncio ou anúncio de algo novo, de algo desejado, esperado em meio ao desespero vivido, perante uma normalidade pesada que não parece deixar nenhuma possibilidade senão uma vida nua". In: AGAMBEN, Giorgio. Profanações. Tradução Selvino José Assmann. São Paulo: Boitempo, 2007, Apresentação, p. 13

${ }^{671}$ AGAMBEN, Giorgio. Política da Profanação. Entrevista concedida à Folha de São Paulo em 18.9.2005. Disponível em http://www.geocities.com/vladimirsafatle/vladi081.htm?200722.
} 
Eis o caminho: a profanação ${ }^{672}$ : se, como visto acima, consagrar (sacrare) designa a saída de bens ou pessoas da esfera humana por meio do sacrifício, de maneira que restem indisponíveis - fora de qualquer livre uso -, profanar assinala a restituição desses bens ou pessoas ao domínio dos homens, quer dizer, a dinâmica do profano assinala a busca da felicidade da humanidade livre, sua libertação. É na profanação que se pode resistir à tradição do sagrado e devolver à comunidade humana aquilo que foi historicamente subtraído ao uso comum por meio da sacralização.

Se a religião, como visto acima, pode ser definida como aquilo que “... subtrai coisas, lugares, animais ou pessoas ao uso comum e as transfere para uma esfera privada" ${ }^{\prime 673}$, não somente inexiste religião sem separação, como toda separação conserva em si um caráter religioso:

“O termo religio, segundo etimologia ao mesmo tempo insípida e inexata, não deriva de religare (o que liga e une o humano e o divino), mas de relegere, que indica a atitude de escrúpulo e de atenção que deve caracterizar as relações com os deuses, a inquieta hesitação (o 'reler') perante as formas - e as fórmulas - que se devem observar a fim de respeitar a separação entre o sagrado e o profano. Religião não é o que une os homens e deuses, mas aquilo que cuida para que se mantenham distintos. Por isso, à religião não se opõem a incredulidade e a indiferença com relação ao divino, mas a 'negligência', uma atitude livre e 'distraída' - ou seja, desvinculada da religio das normas - diante das coisas e do seu uso, diante das formas da separação e do seu significado. Profanar significa abrir a possibilidade de uma forma especial de negligência, que ignora a separação, ou melhor, faz dela um uso particular.",674

\footnotetext{
${ }^{672} \ddot{E}$ importante notarmos a distinção em Agamben entre profanar e secularizar, conforme notas 573 e 574 acima. Enquanto secularizar é aparentemente trazer algo ou alguém da esfera sagrada à humana, este algo ou alguém ainda permanece em relação íntima com - ou conserva em si - o sagrado, não se livra dele, de maneira que resta por ele aprisionado: trata-se somente de uma mudança de local. Profanar, por sua vez, reflete uma independência do sagrado, uma libertação. LELAND DE LA DURANTAYE vislumbra nessa distinção a divergência entre as posições de Agamben e Adorno: "Although Adorno sets the two terms alongside one another, Agamben opposes them, and in so doing he clarifies what he sees as the function and goal of profanation". In: DURANTAYE, Leland. Giorgio Agamben: a critical introduction. Stanford: Stanford University Press, 2009, p. 361-362.

${ }^{673}$ AGAMBEN, Giorgio. Profanações. Tradução Selvino José Assmann. São Paulo: Boitempo, 2007, p. 65.

${ }^{674}$ AGAMBEN, Giorgio. Profanações. Tradução Selvino José Assmann. São Paulo: Boitempo, 2007, p. 66.
} 
E é justamente contra essa lógica da separação que Agamben insurge-se em caminho ao puro, quer dizer, ao profano. De fato, Estados, lei, moral e dignidade ${ }^{675}$, entre outros, teriam sido uma experiência fundada na teologia ou autoridade sagrada e, por conseguinte, na norma - seja divina, seja humana -, e não na sabedoria, inclusive a própria secularização da soberania divina na noção benjaminiana de capitalismo como religião moderna ${ }^{676}$. Assim, tudo aquilo que foi retirado do uso dos homens e da propriedade dos seres humanos deve ser tocado (contato, contagione) ${ }^{677}$, no sentido de profanar o sacro, para sua libertação.

Parece-nos que a profanação poder ser entendida, assim, como um ataque direto a Schmitt, para quem os elementos de sua teoria política são conceitos teológicos secularizados ${ }^{678}$. Pode-se dizer, ainda, que Agamben confronta indiretamente todos aqueles filósofos contemporâneos, pós-modernos ou pós-coloniais, que baseiam suas teorias na primazia dos direitos humanos e na soberania popular, simplesmente porque não há de se pensar mais em lógica da soberania ou sistema de direitos.

Profanar é a arte de viver, que vê na infância ${ }^{679680}$, ou mesmo no prazer da criança $^{681}$, o primeiro lugar de sua realização. Profanar não significa simplesmente abolir e

\footnotetext{
${ }^{675}$ A etimologia de dignidade, de dignitas, remete à classe e à autoridade que competem a cargos públicos, segundo Agamben. Cf. Giorgio AGAMBEN. In: O que resta de Auschwitz: o arquivo e a testemunha. Tradução de Selvino J. Assmann. São Paulo: Boitempo, 2008, p. 73.

${ }^{676}$ Isso porque o capitalismo aniquilaria todo ato profanatório, na medida em que todo meio visaria a um fim (o direito de propriedade, a título de exemplo). "Se hoje os consumidores na sociedae de massa são infelizes, não é só porque consomem objetos que incorporaram em si a própria não-usabilidade, mas também e sobretudo porque acreditam que exercem o seu direito de propriedade sobre os mesmos, porque se tornaram incapazes de os profanar". AGAMBEN, Giorgio. Profanações. Tradução Selvino José Assmann. São Paulo: Boitempo, 2007, p. 73-75.

${ }^{677}$ Outra maneira de profanar, segundo Agamben, é o uso do jogo. Para o autor, a maioria dos jogos que conhecemos deriva de antigas cerimônias sagradas, tal como jogar com a bola que reproduz a luta dos deuses pela posse do Sol ou, ainda, os jogos de azar que derivam de práticas oraculares. Vide AGAMBEN, Giorgio. Infância e história: destruição da experiência e origem da história. Tradução de Henrique Burigo. Belo Horizonte: Editora UFMG, 2005, p. 84.

${ }^{678}$ Gilberto Bercovici esclarece que “... o objeto da teologia politica schmittiana não é a reflexão sobre as ligações entre religião e poder, ou sobre a sacralização do poder, mas um novo estatuto da política moderna, entendida por Schmitt como etapa de um processo de secularização". In: Constituição e estado de exceção permanente: atualidade de Weimar. Rio de Janeiro: Azougue Editorial, 2004, p. 67-68.

${ }^{679}$ Vide nota 45 quanto ao conceito de infância em Agamben.

680 “... infancy does not refer to a stage of human development, but to a more fundamental condition of being without language while nevertheless capable of speaking..." MILLS, Catherine. The philosophy of Agamben. Montreal and Kingston: McGill-Queen's University Press, 2008, p. 108.

${ }_{681}$ "As crianças sentem um prazer especial em se esconder. E não para serem descoberta no final. Há, no próprio fato de ficarem escondidas, no ato de se refugiarem na cesta de roupa ou no fundo de um armário, no de se encolherem num canto do sótão até quase desaparecer, uma alegria incomparável, uma palpitação especial, a que não estão dispostas a renunciar por nenhum motivo". AGAMBEN, Giorgio. Profanações. Tradução Selvino José Assmann. São Paulo: Boitempo, 2007, p. 19.
} 
cancelar as separações, mas aprender a fazer delas um uso novo, a brincar com elas. Agamben parece querer confinar o direito, numa referência direta, queremos crer, a Benjamin e seu Reflexões sobre a criança, o brinquedo e a educação, ao País dos brinquedos - título de um dos capítulos de Infância e história -, o mundo onde um automóvel ou um forno elétrico - graças à miniaturização, que, para Benjamin, é a libertação "dos horrores do real mediante sua reprodução miniaturizada" 682 transformam-se em brinquedos e podem ser sacudidos e desmantelados. Trata-se de tornar o direito inoperante. Justamente porque “... tudo aquilo que é velho, independentemente de sua origem sacra, é suscetivel de virar brinquedo", o direito, como qualquer velharia nas mãos de crianças, deve igualmente encarar o seu destino, quer dizer, um uma vez e um agora não mais, ou melhor, o "uma vez agora não mais" ${ }^{683}$. Aliás, a crítica de Agamben ao direito é claríssima:

"Quase todas as categorias de que nos servimos em matéria moral ou religiosa são de algum modo contaminadas com o direito: culpa, responsabilidade, inocência, julgamento, absolvição... Isso torna difícil usá-las sem precauções bem específicas. Como os juristas sabem muito bem, acontece que o direito não tende, em última análise, ao estabelecimento da justiça. Nem sequer ao da verdade. Busca unicamente o julgamento." ${ }^{684}$

A finalidade do direito seria assim produzir exclusivamente um julgamento, independentemente de fazer justiça ou estabelecer a verdade. O julgamento é a própria finalidade do jurídico. Por conseguinte, a res iudicata em Agamben não esgota o problema, mas é somente um exemplo da substituição da verdade e do justo por uma sentença, a despeito de sua eventual falsidade material. Na sentença, o direito encontra sua paz e "além disso ele não consegue ir" ${ }^{\prime 685}$.

Outro italiano, Francesco CARnelutti, em sua Arte do Direito, revela que “...o Estado perfeito será o Estado que não necessite mais do direito; uma perspectiva, sem

${ }^{682}$ BENJAMIN, Walter. Reflexões sobre a criança, o brinquedo e a educação. Tradução de Marcus Vinicius Mazzari. São Paulo: Duas Cidades, 2002, p. 85.

${ }^{683}$ AGAMBEN, Giorgio. Infância e história: destruição da experiência e origem da história. Tradução Henrique Burigo. Belo Horizonte: Editora UFMG, 2005, p. 85-86.

${ }^{684}$ AGAMBEN, Giorgio. O que resta de Auschwitz: o arquivo e a testemunha. Tradução de Selvino J. Assmann. São Paulo: Boitempo, 2008, p. 28.

${ }^{685}$ AGAMBEN, Giorgio. O que resta de Auschwitz: o arquivo e a testemunha. Tradução de Selvino J. Assmann. São Paulo: Boitempo, 2008, p. 28. 
dúvida muito distante, mas certa, porque a semente está destinada indubitavelmente a transformar-se em árvore carregada de folhas e de frutos ${ }^{\prime \prime 86}$. E continua o pensador $\mathrm{e}$ processualista, cuja fé no direito já se desvanecia em $A$ Morte do direito ${ }^{687}$, obra que conjuga com Agamben a noção de perda da dupla função - certeza e justiça - do direito: "Quando numa família o direito chega a ser supérfluo, quer dizer, quando a armação pode cair sem que caia o arco, o que ocupa o lugar do direito chama-se amor... Por que o pai e o filho cristãos, para regular suas relações, ainda as mais importantes relações não necessitam de direito? Porque, simplesmente, o pai ama o filho e o filho ama o pai. Agora, a sabedoria do povo traduz amar por querer bem, quer dizer, querer o bem do amado, o que não se explica de outra maneira que o reconhecimento que o bem do amado é o bem do amante e reciprocamente. Assim, o bem de um e de outro é o bem da mesma pessoa. Como os tijolos se mantém unidos, depois que o arco está construído, em virtude de uma força interior, também uma força interior une os homens e faz de uma multidão uma unidade; universum, disseram os romanos, para significar o milagre da versio in unum, quer dizer o das partes que formam o todo" ${ }^{\prime 688}$.

É nesse mesmo sentido que SLAVoj ZIZEK localiza a violência divina na esfera do amor, e não na esfera do direito ${ }^{689}$. Parece-nos que é igualmente nesse sentido a busca por um direito novo - vislumbrado por MÁRCIO ALVES DA FONSECA num desconfiado Foucault - liberado ao mesmo tempo dos mecanismos da normalização e daquilo a que se chama de princípio da soberania ${ }^{690}$. Trata-se de buscar uma ação post iudicium, uma moral ou uma responsabilidade, inclusive e principalmente dentro de si, que não reflita um direito ou uma propriedade, mas sim o colapso da separação entre o divino e o humano, entre o humano e o animal ${ }^{691}$ : trata-se do verdadeiro estado de exceção benjaminiano:

\footnotetext{
${ }^{686}$ CARNELUTTI, Francesco. Arte do Direito. 1. ed. Traduçao de Ricardo Rodrigues Gama. Campinas: Bookseller, 2001, p. 19.

${ }^{687}$ Cf. Francesco CARNELUTI. A morte do direito. Tradução de Hiltomar Martins Oliveira. Belo Horizonte: Líder, 2003, p. 7.

${ }^{688}$ CARNELUTTI, Francesco. Arte do Direito, $1^{\text {a }}$ edição. Traduçao de Ricardo Rodrigues Gama. Campinas: Bookseller, 2001, p. 18.

${ }^{689}$ In: Violence. New York: Picador, 2008, p. 205.

${ }^{690}$ Cf. Márcio Alves da FONSECA. In: Michel Foucault e o direito. Tese de doutorado apresentada à Faculdade de Direito da Universidade de São Paulo, 2001, acervo Dedalus, Tomo 32950/02, p. 245-254.

691 "It comes as no surprise, then, that Agamben does not seek to articulate a more precise, more empirical, or less dogmatic determination of the human-animal distinction; rather, he insists that the distinction must be abolished altogether". Matthew CALARCO. Jamming the Anthropological machine. In: CALARCO, Matthew; DECAROLI, Stevens (ed.). Giorgio Agamben: sovereignty and life. Stanford, California: Stanford University Press, 2007, p. 172
} 
'Such a 'real state of exception' would correspond to a world that is 'integrally profane', a world that had employed the devices of profanation so as to disarm the sovereign order and suspend the divisions between the sacred and the profane.",692

Isso porque, como dito acima, diante da confusão que se implementou entre categorias éticas e categorias jurídicas - a contaminação da ética pelo direito -, hoje não seria possível assumir, exemplificativamente, uma culpa e uma responsabilidade sem ingressar no campo do direito. Muito pelo contrário, essa distinção entre categorias ética e jurídica seria usada hoje somente na arrogância da absolvição jurídica: um exemplo dado por Agamben é o tribunal de Nuremberg, em que não raro os acusados declaravam-se eventualmente culpados perante Deus, mas não perante a ordem jurídica aplicável, porquanto somente seguiam ordens, um dever funcional, assim como este argumento foi igualmente utilizado no posterior julgamento de Adolf Eichmann, em Jerusalém, oportunamente retratado em obra específica por Hannah Arendt. Portanto, não se trata de alcançar um direito ou uma propriedade por meio de nossos - enquanto sujeitos de nossas propriedades - esforços, mas por meio da magia: o fim é esquecido e o meio torna-se um puro mezza senza fine. Como descrito no texto Magia e felicidade:

"É uma desgraça sermos amados por uma mulher porque a merecemos! E como é chata a felicidade que é prêmio ou recompensa por um trabalho bem feito!... As crianças, como personagens das fábulas, sabem perfeitamente que, para serem felizes, precisam conquistar o apoio do gênio na garrafa, guardar em casa o burrinho-faz-dinheiro [asino cacabaiocchi] ou a galinha dos ovos de ouro. E, em todas as ocasiões, conhecer o lugar e a fórmula vale bem mais do que esforçar-se honestamente para atingir um objetivo..."693

Buscar a magia, livrar-se de qualquer identidade posta, crer no divino e não aspirar alcançá-lo, são sugestões de Agamben: portanto, Agamben não afasta a idéia de um Deus ou Messias, esteja por vir ou a retornar, mas somente os perigos inerentes à idéia de uma ordem sagrada. Parece-nos que, em termos práticos, Agamben convida-nos a direcionar

${ }^{692}$ DURANTAYE, Leland. Giorgio Agamben: a critical introduction. Stanford: Stanford University Press, 2009 , p. 357.

${ }^{693}$ AGAMBEN, Giorgio. Profanações. Tradução Selvino José Assmann. São Paulo: Boitempo, 2007, p. 23 24. 
nossos esforços a este mundo e a nosso momento, ao invés de aguardar um evento religioso; convida-nos a abandonar todas as soluções apresentadas na modernidade com base na lógica da autoridade e do direito e, especificamente, na lógica do cumprimento da norma como exercício do justo: trata-se de abandonar - repita-se, não se tratar de abolir, mas desativar, tornar inoperante - a própria importância do Estado de Direito e da sociedade de classes. Trata-se da busca de uma maneira de viver cujos valores não estejam vinculados a um código de comportamento, algo semelhante ao uso dos prazeres foucaultiano. De outra forma, só existiram tarefas e o trabalho circular, bem como o consequente sentimento de dívida, e nunca a experiência da ética ${ }^{694}$. Somente na pura potencialidade não há dívida: equivalem-se, assim, o puro, o profano e o livre. Na visão de THANOS ZARTALOUDIS:

"To traverse juridico-political and theological model of democracy still prevalent today what is most in need of separation is the order of happiness from the order of the messianic." $" 695$

Ética e moral não podem ser tarefas originadas da doutrina teológica incorporada no político-jurídico, elas devem ser restituídas à pura potencialidade, à prática transparente. Como esclarece LELAND DE LA DURANTAYE, “Agamben's contention is that law and ethics are separate areas and should be recognized as such" "696. SELVINO ASSMANN revela que, em Agamben, “... é com a profanação que se pode resistir a tudo isso, e que se pode tentar uma nova política, um novo ser humano, uma nova comunidade, pensando e promovendo o avesso da vida nua, a potência da vida, e a vida humana como potência de ser e de não ser ${ }^{\prime 697}$. Eis a nova forma-di-vita, uma figura que pretende superar a exposição da vida nua à violência biosoberana tornando impossível a distinção entre vida biológica e vida política:

"By the term form-of-life, on the other hand, I mean a life that can never be separated from its form, a life in which it is never possible to isolate something

\footnotetext{
${ }^{694}$ Cf. Giorgio AGAMBEN. In: The coming community. Tradução de Michael Hardt. Minneapólis and London: University of Minnesota Press, 2009, p. 42.

${ }^{695}$ ZARTALOUDIS, Thanos. Soulblind, or on profanation. In: CLEMENS, Justin; HERON, Nicholas; MURRAY, Alex (ed.). The work of Giorgio Agamben: law, literature, life. Edinburg University Press, 2008, p. 132.

${ }^{696}$ DURANTAYE, Leland de la. Op. cit., p. 254.

${ }^{697}$ ASSMANN, José Selvino. In: AGAMBEN, Giorgio. Profanações. Tradução Selvino José Assmann. São Paulo: Boitempo, 2007, Apresentação, p. 8.
} 
such as a naked life. A life that cannot be separated from its form is a life for which what is at stake in its way of living is living itself. What does this formlation mean? It defines a life - human life - in which the single ways, acts, and processes of living are never simply facts but always and above all power. Each behavior and each form of human living is never prescribed by a specific biological vocation, nor is it assigned by whatever necessity; instead, no matter how customary, repeated, and socially compulsory, it always retains the character of possibility; that is, it always puts at stake living itself. That is why human beings - as beings of power who can do or not do, succeed or fail, lose themselves or find themselves - are the only beings for whom happiness is always at stake in their living, the only beings whose life is irremediably and painfully assigned to happiness.

Uma forma-de-vida que seja capaz de superar o não ser capaz de não-ser (necessidade) e o ser capaz de não-ser (contingência), uma vida que seja pura singularidade. Isto é, Agamben busca uma vida que seja pura potencialidade livre de qualquer poder político enquanto reflexo da invisível soberania: um "irrevocable exodus from any sovereignty ${ }^{\prime 699}$. Essa nova comunidade marcaria o fim da teologia política da soberania por meio da demolição da estrutura do estado de exceção. A luta pela ética não seria a luta pelo cumprimento da norma existente, mas a luta pela singularidade, um dar-se a si mesmo.

A política além da soberania - que a essa altura já soa uma dificuldade - tornaria possível, por conseguinte, uma comunidade daqueles que, por consenso, existiriam na ética a si inerente. Se a administração da obediência tem sempre sido a primeira tarefa da soberania, é na ruptura dessa obediência que uma alternativa à soberania apareceria: não uma ruptura que leve a uma nova ordem e a uma nova obediência sobre as quais um novo sistema legal será promulgado, mas uma ruptura que permaneça aberta, pois, para Agamben, o retorno do estado de exceção efetivo em que vivemos ao Estado de Direito não é possível, assim como dos campos não há retorno à política clássica. Conceitos como

\footnotetext{
698 AGAMBEN, Giorgio. Means without end: notes on politics. Traducão Vincenzo Binetti e Cesare Casarino. Minneapólis: University of Minnesota Press, 2000. p. 4.

${ }^{699}$ Cf. Giorgio AGAMBEN. In: Means without end: notes on politics. Traducão Vincenzo Binetti e Cesare Casarino. Minneapólis: University of Minnesota Press, 2000, p. 8.
} 
Estado e direito estão agora em questão ${ }^{700}$. Afinal, “... nós não somos apenas, nas palavras de Foucault, animais em cuja política está em questão suas vidas de seres viventes, mas também, inversamente, cidadãos em cujo corpo natural está em questão a sua própria política, ${ }^{, 701}$.

É evidente que essa visão pode ser interpretada como uma impossibilidade políticojurídica, mas se a comunidade além da soberania está a ser aperfeiçoada - a comunità che viene não é um projeto futuro, mas atualíssima ${ }^{702}$-, concordamos que essa questão deve ser analisada prontamente: a profanação do improfanável é a tarefa política da geração que vem $^{703}$. O escrutínio da nuda vita sujeita ao abandono parece realmente ser um bom início.

\footnotetext{
${ }^{700}$ Cf. Giorgio AGAMBEN. In: Estado de exceção. São Paulo: Boitempo, 2004, p. 131.

701 AGAMBEN, Giorgio. Homo sacer: o poder soberano e a vida nua I. Tradução de Henrique Burigo. Belo Horizonte: Editora UFMG, 2002, p. 193.

${ }^{702}$ Cf. Susana SCRAMIM e Vinícius Nicastro HONESKO. In: Introdução a O que é contemporâneo? e outros ensaios. Tradução Vinícius Nicastro Honesko. Chapecó: Argos, 2009, p. 17.

${ }^{703}$ Cf. Giorgio AGAMBEN. Profanações. Tradução Selvino José Assmann. São Paulo: Boitempo, 2007, p. 79.
} 


\section{CONSIDERAÇÕES FINAIS}

Desde o século XVI, o problema da soberania tornou-se central no conceito de político em sua relação com a ordem jurídica - muito embora a autoridade soberana seja certamente anterior em séculos ou milênios -, uma problemática finalmente apresentada em forma de uma questão, quer dizer, um conceito em necessidade de uma teoria.

De Bodin a Hobbes, entre inúmeros outros, as principais questões da política envolveram um desafio singular, seja nas formulações teóricas, seja na prática jurídica: a tarefa de formular e justificar a fundação legítima para as formas crescentes e secularizadas do poder soberano e sua posterior dialética com o poder constituinte. A soberania passaria então a ser considerada como a própria questão da autoridade soberana e seus mecanismos, isto é, a legitimidade do direito de governar e da obrigação de obedecer.

$\mathrm{Na}$ esteira de Foucault, ao abandonar a tradicional questão da legitimidade do poder, Agamben funda sua análise da política numa crítica da própria capacidade de o poder soberano produzir - e reproduzir - sujeitos que consentem e, em última análise, defendem, as condições que tornam a mesma soberania possível. Agamben disserta que a lógica que vincula soberania, sagrado e biopolítica, direciona-nos a um estado no qual um poder supremo pode aniquilar uma inteira minoria em nome da unidade nacional. É o nexo entre o paradoxo da soberania, o sagrado e a biopolítica que torna o campo de concentração o paradigma da política moderna, sendo o regime nazista a sua maior expressão. Se Agamben estiver realmente certo, a estrutura da biopolítica direciona o paradoxo da soberania e a própria democracia moderna para dentro da lógica do extermínio nazista.

É então na intersecção do modelo jurídico do poder e do modelo biopolítico que reside a obra de Agamben, como antecipado na introdução desta dissertação. O seu projeto é vasto, repleto de enigmas, e, por essa razão, permanece amplamente lacunado. Mas as questões que ele levanta, particularmente sobre conceitos como democracia, vontade geral, cidadania, Estado e até mesmo o significado de direitos, inclusive os chamados humanos, são passíveis de nossa atenção. 
No fim de Homo sacer, Agamben apresenta três conclusões provisórias, certamente porque já premeditava as obras vindouras. A primeira delas é externada na frase "a relação política originária é o bando (o estado de exceção como zona de indistinção entre o externo e interno, exclusão e inclusão)", isto é, uma tese que coloca em questão toda teoria de origem contratual ou consensual do poder estatal. A segunda delas, pela qual " $O$ rendimento fundamental do poder soberano é a produção da vida nua como elemento político original e como limiar de articulação entre natureza e cultura, zoé e bíos", implica que a política ocidental sempre foi uma biopolítica. E, a terceira conclusão, pela qual "o campo, e não a cidade, é hoje o paradigma biopolítico do Ocidente" ${ }^{704}$, traça uma sinistra percepção de que ainda hoje vivemos sobre as relações mais facilmente perceptíveis nos Estados totalitários dos Novecentos.

Isto é, se aceitarmos seriamente as reivindicações de Agamben, seria difícil imaginarmos uma ordem global menos livre do que a hoje existente, como ressalta PATRICIA OWENS ${ }^{705}$. Mas isso é realmente verossímil ou se trata somente de uma visão pessimista $^{706}$ ? Nas páginas de suas obras, Agamben traça a teoria e a prática da soberania, cruzando-a através da era moderna até os primeiros dias da jurisprudência romana, revelando nesse caminho os seus próprios limites. A genealogia que ele traça abre a porta para uma crítica do discurso político Ocidental, oferecendo-nos uma oportunidade de identificar áreas onde uma nova política, liberada do privilégio da soberania, poderia focar sua atenção.

Muito da discussão da soberania se volta à figura do indivíduo banido. É de fato uma provocativa linha de pesquisa, revelando não somente como a soberania se manifesta como uma força, mas também como seus efeitos são carregados por aqueles que aparentemente foram dela excluídos.

\footnotetext{
${ }^{704}$ AGAMBEN, Giorgio. Homo sacer: o poder soberano e a vida nua I. Tradução de Henrique Burigo. Belo Horizonte: Editora UFMG, 2002, p. 187.

${ }^{705}$ OWENS, Patricia. Beyond 'bare life': refugees and the 'right to have rights'. Disponível em http://www.allacademic.com/one/isa/isa09/index.php?cmd=isa09_search\&offset $=0 \&$ limit $=5 \&$ multi_search_s earch_mode $=$ publication\&multi_search_publication_fulltext_mod $=$ fulltext\&textfield_submit $=$ true\&search_

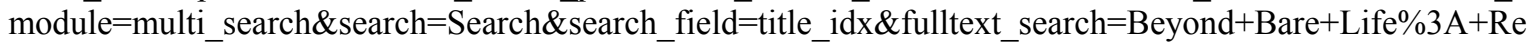
fugees + and + the $+\%$ E2\%80\%9CRight + to + Have + Rights $\% \bar{E} 2 \% 80 \% 9 \mathrm{D}$. Acessado em 3.12.2009.

${ }^{706}$ Para Jenny Edkins, "His analysis of the camp as the nomos of contemporary political life has proved very fruitful, as has his discussion of the state of exception, but his overall prognosis is taken by many to be a pessimistic one". In: Whatever Politics. In: CALARCO, Matthew; DECAROLI, Stevens (ed.). Giorgio Agamben: sovereignty and life. Stanford, California: Stanford University Press, 2007, p. 70.
} 
O trabalho de Agamben, contudo, convida-nos a reexaminar as bases da autoridade jurídico-política num confronto para, ao invés de justificar o poder soberano - mas partindo da existência de um estado de exceção contínuo ${ }^{707}$-, conceber uma comunidade política que não a pressupõe. Agamben não pretende romper a roda do paradoxo da soberania - em que toda causa é o efeito de uma causa anterior - e encontrar um ponto de partida lógico, seja o soberano, sejam os direitos humanos e assim por diante, mas desativá-la. Em outras palavras, ele coloca no centro de sua obra a projeção de uma comunidade além da tradição da soberania: o abandono das narrativas patrióticas. No lugar de uma gênese convencional, Agamben instala um novo horizonte político na esfera de uma comunidade que vem. Tratase de um projeto que envolve a reviravolta de termos, mas, ainda assim, uma consciência sustentada de uma inseparabilidade da política e da subjetividade.

Não obstante, nada em seu raciocínio apresenta concretamente, em nosso entendimento, um caminho para fora da lógica apresentada (ou talvez a recusa de lecionar em território estadunidense seja, por si só, um exemplo prático?). Inclinamo-nos, nesse sentido, a concordar com ERNESTO LACLAU, para quem "We are not told anything about what a movement out of the paradox of sovereignty and 'towards a politics freed from any ban' would imply":

"Instead of deconstructing the logic of political institutions, showing areas in which forms of struggle and resistance are possible, he closes them beforehand

\footnotetext{
${ }^{707}$ Essa é a conclusão dos brasileiros Vitor Hugo Nicastro HONESKO, Raquel Schlommer HONESKO e Tatiane Alves BARBOSA: "De tudo o que já foi exposto, não resta dúvidas de que o Brasil vive sob um regime de exceção. O Poder Legislativo nada mais faz do que ratificar os atos do Executivo. E mais: o órgão que deveria guardar a Constituição, representado pelo Supremo Tribunal Federal (STF), ao invés de intervir nas tão cristalinas deturpações do texto constitucional por parte do Executivo, na grande maioria das vezes cede juridicidade para estes gravíssimos abalos nas estruturas do Estado Democrático de Direito. ... Ao ler a Constituição da República Federativa do Brasil de 1988, percebe-se que muitos princípios informadores de um Estado Democrático de Direito estão sendo relegados ao ostracismo. Princípios como o da soberania popular, garantidor máximo da dignidade da pessoa humana, são hodiernamente desrespeitados por um governo que simplesmente pensa em governar para si mesmo. Este governo, representado pelo Presidente da República, possui o poder soberano, que legitimamente deveria pertencer a todos os cidadãos. As medidas provisórias eas constantes Reformas Constitucionais só fazem demonstrar a ingerência do governo em relação às instituições democráticas brasileiras. Não como sequer sonhar com um Estado Democrático de Direito se o que vive hoje em todo o mundo é uma guerra civil legal. Ainda mais no Brasil, país de dimensões continentais, que também promove distâncias constinentais entre ricos e pobres, consumidores $e$ não-consumidores, entre o Povo e o povo". In: O estado de exceção como causa da corrupção no sistema político-constitucional brasileiro. In: Revista do Instituto dos Advogados de São Paulo, ano 9, n. 17, janeiro-julho 2006. São Paulo: Editora Afiliada, 2006, p. 269.
} 
through an essentialist unification. Political nihilism is his ultimate message.",708

WiLLIAM CONNOLLY tende a concordar com essa posição, uma vez que “... nowhere in Homo Sacer, however, is a way out of the logic actually disclosed." ${ }^{\text {,09 }}$. No mesmo sentido MATTHEW CALARCO, para quem “... even the most charitable reading of Agamben's work must acknowledge that, should Agamben wish to debate the kinds of questions posed by neo-humanists or desconstructionists, much remains to be worked out at both the theoretical and concrete political level" ${ }^{, 710}$ e, ainda, STEVEN DECAROLI ${ }^{711}$, CATHERINE MiLls ${ }^{712}$ e ARNE De BOEVER ${ }^{713}$.

Em que pese a profundidade de sua análise e cuidadosa explanação quanto às estruturas paralelas entre o abandono e o soberano, comparativamente poucas sugestões foram de fato escritas quanto às possibilidades de escapar dessa relação. Muito pode ser lido quanto o esqueleto jurídico do banimento e suas origens na figura do romano homo sacer, bem como sua exclusão inclusiva com respeito à lei e à evocação da exceção soberana, mas pouco é apresentado sobre as ações reais e específicas que, por uma razão ou outra, levar-nos-iam à libertação dessa estrutura.

Dentro do contexto de um projeto amplamente preocupado com alternativas às formulações soberanas do poder - uma política livre de qualquer banimento -, há virtualmente muito a ser ganho se soubéssemos como quebrar essa formulação. Parecenos, até mesmo, que o próprio Agamben não sabe quais as consequências de seu pensamento:

${ }^{708}$ LACLAU, Ernesto. Bare life or social indeterminacy? In: CALARCO, Matthew; DECAROLI, Stevens (ed.). Giorgio Agamben: sovereignty and life. Stanford, California: Stanford University Press, 2007. p. 22.

${ }^{709}$ Cf. William E. CONNOLLY. The complexities of sovereignty. In: CALARCO, Matthew; DECAROLI, Stevens (ed.). Giorgio Agamben: sovereignty and life. Stanford, California: Stanford University Press, 2007. p. 27.

${ }^{710}$ Matthew CALARCO. Jamming the Anthropological machine. In: CALARCO, Matthew; DECAROLI, Stevens (ed.). Giorgio Agamben: sovereignty and life. Stanford, California: Stanford University Press, 2007. p. 173.

711 DECAROLI, Steven. Boundary Stones. In: CALARCO, Matthew; DECAROLI, Stevens (ed.). Giorgio Agamben: sovereignty and life. Stanford, California: Stanford University Press, 2007, p. 45-46.

${ }^{712}$ MILLS, Catherine. The philosophy of Agamben. Montreal and Kingston: McGill-Queen's University Press, 2008, p. 108.

${ }^{713}$ BOEVER, Arne de. Politics and poetics of divine violence: on a figure in Giorgio Agamben and Walter Benjamin. In: CLEMENS, Justin; HERON, Nicholas; MURRAY, Alex. The work of Giorgio Agamben: law, literature, life. Edinburg University Press, 2008, p. 91. 
"... What other consequences thought can draw from the awareness of its own essential inactivity, and whether, in general, there is a politics possible today that is equal to the absence of a work of man, and will not simply fall back into the assumption of a biopolitical task - this must for now remain suspense."714

Ou seja, Agamben, assim como Benjamin, deixa nítido que devemos caminhar a uma nova estrutura, mas não nos oferece os meios: "Yet neither Agamben nor Benjamin can say what the grand Other of the structure of sovereignty may be, only that it ought to be; that if and when it comes, it will come with an all consuming but bloodless violence that, in Benjamin's terms, will be divine, not mythic, neither law-making nor lawpreserving; and that if and when it comes, it will institute a new, post-sovereign, post-ruleof-law, historical epoch" ${ }^{, 715}$. Aliás, talvez isso se dê justamente porque não devamos enxergar nossos passos como meios rumo a essa nova política enquanto fim, mas como meios sem fim.

Uma resposta concreta e praticável ao paradoxo da soberania parece-nos crucial para chegarmos a uma política viável além da soberania, uma política onde os conceitos de soberania e poder constituinte, que são o centro de nossa tradição político-jurídica, seriam desativados ou, ao menos, repensados integralmente. DECAROLI igualmente entende que:

"The task for a politics beyond sovereignty, a difficult and perhaps ultimately impossible task, is to realize a community of those who, by consensus or custom, are laws unto themselves - exemplars or exiles. This vision has, of course, often been ruled out as a political impossibility, but if a community beyond sovereignty is to be realized, this issue must be addressed. The waysof-life subject to banishment suggest a place to begin.,"716

Assim, justamente porque Agamben entende que a lógica do nazismo - reproduzida nas democracias modernas - é desastrosa, haveria bastante espaço, em nosso entendimento, para pressionar Agamben a nos fornecer um mais prático caminho à nova política que ele

\footnotetext{
${ }^{714}$ AGAMBEN, Giorgio. The work of man. In: CALARCO, Matthew; DECAROLI, Stevens (ed.). Giorgio Agamben: sovereignty and life. Stanford, California: Stanford University Press, 2007, p. 10.

${ }^{715}$ RASCH, William. In: From sovereign ban to banning sovereignty. In: CALARCO, Matthew; DECAROLI, Steven (ed.). Giorgio Agamben: sovereignty and life. Stanford, California: Stanford University Press, 2007, p. 99.

${ }^{716}$ DECAROLI, Stevens. Op. cit., p. 69.
} 
descreve. Talvez não haja resposta. Talvez a mera aceitação da crise dos conceitos expostos revele per se um roteiro. Talvez a mera compreensão da relação originária entre stato di eccezione, direito e vida nua seja justamente o primeiro passo para la comunità che viene. 


\section{BIBLIOGRAFIA}

\section{Trabalhos de Giorgio Agamben}

AGAMBEN, Giorgio. A idéia da prosa. Tradução de João Barrento. Lisboa: Cotovia, 1999.

. A Linguagem e a Morte: um seminário sobre o lugar da negatividade. Tradução de Henrique Burigo. Belo Horizonte: Editora UFMG, 2006.

- A Política da profanação. Entrevista concedia à Folha de São Paulo em 18.9.2005. Disponível em http://www.geocities.com/vladimirsafatle/vladi081.htm?200722.

Bartleby, or on contingency. In: HELLER-ROAZEN, Daniel (ed.). Potentialities. Tradução de Daniel Heller-Roazen. Stanford: Stanford University Press, 1999.

. Ein gespräch mit Giorgio Agamben: das leben, ein kunstwerk ohne autor: der Ausnahmezustand, die verwaltung der unordnung und das private leben. Disponível em www.suddeutschezeitung.com, edição de 6.4.2004. Versão em inglês disponível em German Law Journal, n. 5, special edition. Disponível em http://www.germanlawjournal.com/article.php?id=437.

. El reino y la gloria: una genealogía de la economía y del gobierno. Homo sacer II,2. Tradução de Flavia Costa, Edgard Castro e Mercedes Ruvituso. Buenos Aires: Adriana Hidalgo, 2008.

. Entrevista com Giorgio Agamben. Revista do Departamento de Psicologia, UFF,

v. $18, \quad$ n. $1, \quad$ janeiro/junho 2006. Disponível em http://www.scielo.br/scielo.php?pid=S0104.-80232006000100011\&script=sci_arttext.

. Estâncias: a palavra e o fantasma na cultura ocidental. Tradução de Selvino J. Assmann. Belo Horizonte: Editora UFMG, 2007. 
. Homo sacer: il potere sovrano e la nuda vita. Turin: Einaudi, 1995. Homo sacer: o poder soberano e a vida nua I. Tradução de Henrique Burgo. Belo Horizonte: Editora UFMG, 2002.

Infância e história: destruição da experiência e origem da história. Tradução de Henrique Burigo. Belo Horizonte: Editora UFMG, 2005.

Infancia e historia: destrucción de la experiência y origen de la historia. 3. ed. Tradução de Silvio Mattoni. Buenos Aires: Adriana Hidalgo, 2004.

Intervista a Giorgio Agamben: dalla teologia política alla teologia-economica. Rivista online, Scuola superiore dell'economia e delle finanze, anno 1, n. 4, 2004. Disponível em http://rivista.ssef.it/site.php?page=\&edition=2004-04-01. Versão em português in Revista Internacional Interdisciplinar Interthesis, v. 2, n. 2, jul/dez 2005.

. Il sacramento del linguaggio: archeologia del giuramento. Homo sacer II.3. Roma e Bari: Laterza, 2008.

. Il tempo che resta: un commento alla Lettera ai Romani. Turin: Bollati Boringhieri, 2000. The time that remains: a commentary on the Letter to the Romans. Tradução de Patricia Dailey. Stanford: Stanford University Press, 2005.

La comunità che viene. Turin: Einaudi, 1990. The coming community. Tradução de Michael Hardt. Minneapólis and London: University of Minnesota Press, 2009.

. Language and history: linguistic and historical categories in Benjamin's thought. In: HELLER-ROAZEN, Daniel (ed.). Potentialities. Tradução de Daniel HellerRoazen. Stanford: Stanford University Press, 1999.

. L'aperto, l'uomo, l'animale. Torino: Bolatti Boringuieri, 2002. The open: man and animal. Tradução de Kevin Attell. Stanford: Stanford University Press, 2004. 
L'uomo senza contenuto. Macerata: Quodlibet, 1994. The man without content. Tradução de Georgia Albert. Stanford: Stanford University Press, 1999.

. Means without end: notes on politics. Tradução de Vincenzo Binetti e Cesare Cesarino. Minneapolis and London: University of Minnesota Press, 2000.

. Movement. Tradução de Arianna Bove. Disponível em http://www.generationonline.org/p/fpagamben3.htm.

. Non au tatouage biopolitique. Le Monde, edição de 11.1.2004. Disponível em http://www.lemonde.fr/cgi-

bin/ACHATS/ARCHIVES/archives.cgi?ID=6152d1b7066b69ae92c86b2e2a561b716717b 1360dd705b0.

. Note liminaire sur le concept de démocratie. In: Démocratie dans quel état? Paris: La Fabrique éditions, 2009.

. O que é o contemporâneo? E outros ensaios. Tradução de Vinícius Nicastro Honesko. Chapecó: Argos, 2009.

. On potentiality. In: HELLER-ROAZEN, Daniel (ed.). Potentialities. Tradução de Daniel Heller-Roazen. Stanford: Stanford University Press, 1999.

. On security and terror. Frankfurter Allgemeine Zeitung (20.9.2001). Tradução de Soenke Zehle. Disponível em http://fazarchiv.faz.net/webcgi?START=A20\&DOKM=775258_FAZ_0\&WID-693435800873-11505_4 e http://www.egs.edy/faculty/agamben/agamben-on-security-andterror.html.

- Pardes: the writing of potentiality. In: HELLER-ROAZEN, Daniel (ed.). Potentialities. Tradução de Daniel Heller-Roazen. Stanford: Stanford University Press, 1999. 
Per una filosofia dell'infanzia. Disponível em

http://www.yorku.ca/public/public/backissu/v21_1.html.

. Profanações. Tradução de Selvino J. Assmann. São Paulo: Boitempo, 2007.

Quel che resta di Auschwitz: l'archivo e il testimone. Torino: Bollati Boringhieri, 1998. O que resta de Auschwitz: o arquivo e a testemunha. Tradução de Selvino J. Assmann. São Paulo: Boitempo, 2008.

. Stato di eccezione. Torino: Bollati Boringhieri, 2003. Estado de Exceção. Homo sacer II,1. Tradução de Iraci D. Poleti. São Paulo: Boitempo, 2004.

. Terrorismo o tragicommedia. Disponível em http://www.egs.edu/faculty/giorgioagamben/articles/.

. The idea of language. In: HELLER-ROAZEN, Daniel (ed.). Potentialities. Tradução de Daniel Heller-Roazen. Stanford: Stanford University Press, 1999.

. The Messiah and the sovereign: the problem of law in Walter Benjamin. In: HELLER-ROAZEN, Daniel (ed.). Potentialities. Tradução de Daniel Heller-Roazen. Stanford: Stanford University Press, 1999.

. The signature of all things: on method. Tradução de Luca D'Isanto e Kevin Attell. New York: Zone Books, 2009.

. The state of emergency. Disponível em http://www.generationonline.org/p/fpagambenschmitt.htm.

. The Work of man. In: CALARCO, Matthew; DECAROLI, Steven (ed.). Giorgio Agamben: sovereignty and life. Stanford, California: Stanford University Press, 2007.

- Walter Benjamin and the demonic: happiness and historical redemption. In: HELlER-ROAZEN, Daniel (ed.). Potentialities. Tradução de Daniel Heller-Roazen. Stanford: Stanford University Press, 1999. 
. We refugees. Tradução de Michael Rocke. The European Graduate School. Disponível em http://egs.edu/faculty/agamben/agamben-we-refugees.html.

. What is a paradigm? European Graduate School, August 2002. Disponível em http://www.egs.edu/faculty/agamben/agamben-what-is-a-paradigm-2002.html. Acessado em 20.9.2007. 


\section{OUTROS TEXTOS}

ADORNO, Theodor W.; HORKHEIMER, Max. Dialética do esclarecimento. Tradução de Guido Antonio de Almeida. Rio de Janeiro: Jorge Zahar Ed., 1985.

ALVES, José Carlos Moreira. Direito romano. 6. ed. Vol. I e II. Rio de Janeiro: Forense, 2003.

ALVES, Daniel; MEIRELLES, Mauro. Humanismo latino e opiniões acerca da pena de morte. In: BOMBASSARO, Luiz Carlos Bombassaro; RI JR., Arno Dal; PAVIANI, Jayme Paviani (org.). As interfaces do humanismo latino. Porto Alegre: EDIPUCRS, 2004.

AMARAL SANTOS, Moacyr. O Estado de emergência. São Paulo: Revista dos Tribunais, 1981.

ARENDT, Hannah. A Condição Humana. 10. ed. Tradução de Roberto Raposo. Rio de Janeiro: Forense Universitária, 2008.

. Origens do Totalitarismo: anti-semitismo, imperialismo, totalitarismo. 7. ed. Tradução de Roberto Raposo. São Paulo: Companhia da Letras, 1989.

. Walter Benjamin: 1892-1940. In: Illuminations. Tradução de Harry Zohn. New York: Schoken Books, 1969.

. Eichmann in Jerusalem: a report on the banality of evil. New York: Penguin Books, 1963.

ARISTÓTELES. Ética a Nicômaco. Tradução de Pietro Nassetti. São Paulo: Martin Claret, 2003.

. Metafísica. v. II, 2 ed. Tradução de Giovanni Reale. São Paulo: Edições Loyola, 2005 
. Metafísica. Tradução de Leonel Vallandro. Porto Alegre: Editora Globo, 1969, p. 194.

. Metafísica. 3. ed. Tradução de Patricio de Azcárte. Buenos Aires: Ed. EspanaCalpe Argentina S.A., 1945.

Poítica. 3. ed. Tradução de Mário da Gama Kury. Brasília: Editora Universidade de Brasília, 1997.

ASSMANN, Selvino José. In: Apresentação a AGAMBEN, Giorgio. Profanações. Tradução Selvino José Assmann. São Paulo: Boitempo, 2007,

BAUMAN, Zygmunt. Medo líquido. Tradução de Carlos Alberto Medeiros. Rio de Janeiro: Jorge Zahar Ed., 2008.

. Modernidade líquida. Tradução de Plínio Dentzien. Rio de Janeiro: Jorge Zahar Ed., 2001.

BENJAMIN, Walter. Reflexões sobre a criança, o brinquedo e a educação. Tradução de Marcus Vinicius Mazzari. São Paulo: Duas Cidades, 2002.

Zur kritik der gewalt und andere aufsätze. Frankfurt: Suhrkamp Verlag, 1965. Critique of violence. In: BULLOCK, Marcus; JENNINGS, Michael (ed.). Selected writings, v. 1, 1913-1926. Tradução de Edmund Jephcott. Cambridge: Harvard University Press, 1996.

. Origem do drama barroco alemão. Tradução de Sérgio Paulo Rouanet. São Paulo: Brasiliense, 1984.

. Sobre arte, técnica, linguagem e política. Traduçao de Maria Luz Moita e Manuel Alberto. Lisboa: Relógio D’água Editores, 1992

. Illuminations. Tradução de Harry Zohn. New York: Schoken Books, 1969. 
On the concept of history. In: EILAND Howard; JENNINGS, Michael (ed.). Selected writings, v. 4, 1938-1940. Tradução de Harry Zohn. Cambridge: Harvard University Press, 2003.

BERCOVICI, Gilberto. Soberania e Constituição: para uma crítica do constitucionalismo. São Paulo: Quartier Latin, 2008.

. Constituição e estado de exceção permanente: atualidade de Weimar. Rio de Janeiro: Azougue Editorial, 2004.

. Breves considerações sobre o poder de iniciativa legislativa do Executivo. Revista da Procuradoria Geral do Município de Fortaleza, v. 12, 2004.

BILLIER, Jean-Cassien; MARYOLI, Aglaé. História da filosofia do direito. Tradução de Maurício de Andrade. Barueri: Manole, 2005.

BITTAR, Eduardo Carlos Bianca. O Direito na pós-modernidade. Rio de Janeiro: Forense Universitária, 2005.

- Curso de filosofia aristotélica: leitura e interpretação do pensamento aristotélico. Barueri: Manole, 2003

BOBBIO, Norberto. Do fascismo à democracia: os regimes, as ideologias, os personagens e as culturas políticas. Tradução de Daniela Beccaccia Versiani. Rio de Janeiro: Elsevier, 2007.

Direito e Poder. Tradução de Nilson Moulin. São Paulo: Editora UNESP, 2008.

. Estado, governo e sociedade: para uma teoria geral da política. 14. ed. Tradução de Marco Aurélio Nogueira. Rio de Janeiro: Paz e Terra, 1987.

BONAVIDES, Paulo. Teoria constitucional da democracia participativa. Por um direito constitucional de luta e resistência. Por uma nova hermenêutica. Por uma repolitização da legitimidade. São Paulo: Malheiros Editores, 2001. 
. Governança e legitimidade (alguns aspectos da conjuntura brasileira). In: VALADÉS, Diego (Ed.). Gobernabilidad y constitucionalismo en América Latina. México: Universidad Nacional Autónoma de México, 2005

BULL, Malcolm. States don't really mind their citizens dying (provided they don't all do it at once): they just don't like anyone else to kill them. Disponível em http://www.generation-online.org/p/fpagamben2.htm.

BURDEAU, Georges. O Estado. Tradução de Maria Ermantina de Almeida Prado Galvão. São Paulo: Martins Fontes, 2005.

BUTLER, Judith. Precarious life: the powers of mourning and violence. London e New York: Verso, 2004.

CABRAL, Paulo Roberto dos Santos. Teoria constitucional e exceção permanente: uma categoria para a teoria constitucional do século XXI. Curitiba: Jaruá, 2009.

CALARCO, Matthew. Jamming the Anthropological machine. In: CALARCO, Matthew; DECAROLI, Steven (ed.). Giorgio Agamben: sovereignty and life. Stanford, California: Stanford University Press, 2007.

CALARCO, Matthew; DECAROLI, Steven. Giorgio Agamben, Sovereignty \& Life. Stanford: Stanford University Press, 2007.

CALDEIRA, Teresa Pires do Rio. Cidade de muros: crime, segregação e cidadania em São Paulo. Tradução de Frank de Oliveira e Henrique Monteiro. São Paulo: Edusp, 2000.

CANGUILHEM, Georges. O normal e o patológico. 6. ed. Tradução de Maria Thereza Redig de Carvalho Barrocas. Rio de Janeiro: Forense Universitária, 2009.

CANOTILHO, José Joaquim Gome. Direito Constitucional. 5. ed. Coimbra: Almedia, 1993. 
CARNELUTTI, Francesco. Arte do direito: seis meditações sobre o direito. Tradução de Ricardo Rodrigues Gama. Campinas: Bookseller, 2003.

. A morte do direito. Tradução de Hiltomar Martins Oliveira. Belo Horizonte: Líder, 2003.

CAVENDISH, Sueli. Poiésis, negatividade e a condição moderna da arte em Giorgio Agamben. Disponível em http://paginas.terra.com.br/arte/dubitoergosum/a41.htm.

CHUERI, Vera Karam de. Agamben e o estado de exceção como zona de indeterminação entre o político e o jurídico. In: FONSECA, Ricardo Marcelo (org.). Crítica da Modernidade: diálogos com o Direito. Florianópólis: Fundação Boiteux, 2005.

CLEMENS, Justin. The role of the shifter and the problem of reference in Giorgio Agamben. In: CLEMENS, Justin; HERON, Nicholas, MURRAY, Alex (ed.). The work of Giorgio Agamben: law, literature, life. Edinburg University Press, 2008.

CLEMENS, Justin; HERON, Nicholas; MURRAY, Alex. The enigma of Giorgio Agamben. In: CLEMENS, Justin; HERON, Nicholas; MURRAY, Alex (ed.). The work of Giorgio Agamben: law, literature, life. Edinburg University Press, 2008.

CLEMENS, Justin; HERON, Nicholas; MURRAY, Alex (ed.). The work of Giorgio Agamben: law, literature, life. Edinburgh University Press, 2008.

COCCO, Giuseppe; PILATTI, Adriano. Desejo e libertação: a potência constituinte da multidão. In: NEGRI, Antonio. Poder Constituinte: ensaio sobre as alternativas da modernidade. Tradução de Adriano Pilatti. Rio de Janeiro, DP\&A, 2002.

COELHO, Fábio Ulhoa. Para entender Kelsen. 5. ed. São Paulo: Saraiva, 2009.

COHEN, G. A. Karl Marx's theory of history: a defence. New Jersey: Princiton University Press, 2000. 
CONNOLY, William E. The complexities of sovereignty. In: CALARCO, Matthew; DECAROLI, Steven (ed.). Giorgio Agamben: sovereignty and life. Stanford, California: Stanford University Press, 2007.

COOPER, Robert. The breaking of nations: order and chaos in the twnety-first century. New York: Palgrave, 2003.

CORVAL, Paulo Roberto dos Santos. Teoria constitucional e exceção permanente: uma categoria para a teoria constitucional do século XXI. Curitiba: Juruá, 2009.

COULANGES, Fustel de. A cidade antiga. Tradução de Fernando de Aguiar. São Paulo: Martins Fontes, 2000.

CRACOGNA, Dante. Acerca del concepto de constitucion en Carl Schmitt y Hans Kelsen. Revista Facultad de Derecho y Ciências Políticas, Universidad Pontifícia Bolivariana, n. 75, outubro-dezembro 1986.

DECAROLI, Steven. Boundary stones: Giorgio Agamben and the field of sovereignty. In: CALARCO, Matthew; DECAROLI, Steven (ed.). Giorgio Agamben: sovereignty and life. Stanford, California: Stanford University Press, 2007.

DERRIDA, Jacques. Força de lei: o fundamento místico da autoridade. Tradução de Leyla Perrone-Moisés. São Paulo: Martins Fontes, 2007.

. Aporias. Tradução de Thomas Dutoit. Stanford: Stanford University Press, 1993.

DURANTAYE, Leland de la. Giorgio Agamben: a critical introduction. Stanford: Stanford University Press, 2009.

DÜTTMANN, Alexander García. Integral actuality: on Giorgio Agamben's Idea of Prose. In: CLEMENS, Justin; HERON, Nicholas, MURRAY, Alex (ed.). The work of Giorgio Agamben: law, literature, life. Edinburg University Press, 2008. 
EDKINS, Jenny. Whatever Politics. In: CALARCO, Matthew; DECAROLI, Steven (ed.). Giorgio Agamben: sovereignty and life. Stanford, California: Stanford University Press, 2007.

FARALLI, Carla. A Filosofia Contemporânea do Direito: temas e desafios. Tradução de Candice Preamaor Gullo. São Paulo: Martins Fontes, 2006.

FERRAZ JR., Tercio Sampaio. Estudos de Filosofia do Direito: reflexões sobre o Poder, a Liberdade, a Justiça e o Direito. 3. ed. São Paulo: Atlas, 2009.

. Introdução ao Estudo do Direito: técnica, decisão, dominação. São Paulo, Atlas, 2001

Decreto-lei, instrumento discricionário. Disponível em http://www.terciosampaioferrazjr.com.br/?q=/publicacoes-cientificas/36.

FERREIRA, Bernardo. O Risco do Político: crítica ao liberalismo e teoria política no pensamento de Carl Schmitt. Belo Horizonte: Editora UFMG; Rio de Janeiro, IUPERJ, 2004.

FERREIRA, Olavo Augusto Vianna Alves. Sistema constitucional das crises: restrições a direitos fundamentais. Rio de Janeiro: Forense; São Paulo: Método, 2009.

FERREIRA, Luis Pinto. Princípios gerais de direito constitucional moderno. Tomo I. São Paulo: Revista dos Tribunais.

FERREIRA FILHO, Manoel Gonçalves. Curso de Direito Constitucional. 30. ed. São Paulo: Saraiva, 2003. . O poder constituinte. 5. ed. São Paulo: Saraiva, 2007.

FERRIS, David S. (ed.). The Cambridge companion to Walter Benjamin. Cambridge: The Cambridge University Press, 2004. 
FINAZZI-AGRÒ, Ettore. A voz de quem morre. O indício e a testemunha em "Meu tio Iauraretê". Disponível

em http://www.letras.ufmg.br/poslit/08_publicacoes_txt/er_12/er12_ef.pdf.

FONSECA, Márcio Alves da. Michel Foucault e o direito. Tese de doutorado apresentada à Faculdade de Direito da Universidade de São Paulo, 2001, acervo Dedalus, Tomo $32950 / 02$.

FONSECA, Ricardo Marcelo. Foucault, o direito e a "sociedade de normalização". In: Crítica da modernidade: diálogos com o direito. Florianópólis: Fundação Boiteux, 2005

FORBES, Jorge; REALE JÚNIOR, Miguel; FERRAZ JR., Tercio Sampaio (orgs.). $A$ invenção do futuro: um debate sobre a pós-modernidade e a hipermodernidade. Barueri: Manole, 2005.

FORMIS, Barbara. Dismantling theatricality: aesthetics of bare life. In: CLEMENS, Justin; HERON, Nicholas, MURRAY, Alex (ed.). The work of Giorgio Agamben: law, literature, life. Edinburg University Press, 2008.

FOUCAULT, Michel. Vigiar e Punir: história da violência nas prisões. Tradução de Raquel Ramalhete. 36. ed. Petrópolis: Editora Vozes, 2001.

. Microfísica do Poder. 27. ed. Tradução de Roberto Machado. Rio de Janeiro: Graal, 2009.

Em defesa da sociedade. Tradução de Maria Hermantina Galvão. São Paulo: Martins Fontes, 1999.

Resumos dos cursos do Collège de France (1970-1982). Rio de Janeiro: Jorge Zahar Ed., 1997.

História da sexualidade 1: a vontade de saber. 19. ed. Tradução de Maria Thereza da Costa Albuquerque e J. A. Guilhon Albuquerque. Rio de Janeiro: Graal, 2009. 
História da sexualidade 3: o cuidado de si. 9. ed. Tradução de Maria Thereza da Costa Albuquerque. Rio de Janeiro: Graal, 2007.

. A verdade e as formas jurídicas. 3. ed. Tradução de Roberto Cabral de Melo Machado e Eduardo Jardim Moraes. Rio de Janeiro: NAU Ed., 2003.

Os anormais: curso no Collège de France (1974-1975). Tradução de Eduardo Brandão. São Paulo: Martins Fontes, 2002.

. Nascimento da biopolítica: curso no Collège de France (1978-1979). Tradução de Eduardo Brandão. São Paulo: Martins Fontes, 2008.

FRASER, David. Dead men walking: law and ethics after Giorgio Agamben's Auschwitz. International Journal for the Semiotics of Law, v. 12(4), 1999.

FROSINI, Tommaso Edoardo. El Estado de derecho se há detenido em Guantánamo. Revista Española de Derecho Constitucional, ano 26, n. 76, janeiro-abril de 2006.

GAGNEBIN, Jeanne Marie. In: Apresentação a AGAMBEN, Giorgio. O que resta de Auschwitz: o arquivo e a testemunha. Tradução de Selvino J. Assmann. São Paulo: Boitempo, 2008.

GHETTI, Pablo Sanges. Direito e democracia sob os espectros de Schmitt: contribuição à crítica da filosofia do direito de Jürgen Habermas. Rio de Janeiro: Lúmen Juris, 2006.

GULLI, Bruno. The ontology and politics of exception: reflections on the work of Giorgio Agamben. In: CALARCO, Matthew; DECAROLI, Steven (ed.). Giorgio Agamben: sovereignty and life. Stanford, California: Stanford University Press, 2007.

HARTLE, Johann Frederik. Das unbestimmte dritte. Giorgio Agambens messianismus des rechts. Disponível em http://www.literaturkritik.de/public/rezension.php?rez_id=7435\&ausgabe=200410. 
HAWKINS, Seth J. Up Guantanamo without a paddle: waves of Afghan detainees drown in America's great habeas loophole. In: Saint Louis University Law Journal. Vol. 47, No. 4, Summer 2003.

HEIDEGGER, Martin. Ser e Tempo. Tradução de Márcia Sá Cavalcante Schuback. Petrópolis: Vozes; Bragança Paulista: Editora Universitária São Francisco, 2007.

HELLER-ROAZEN, Daniel. Editor' introduction: To read what was never written. In: HAMACHER, Werner; WELBERY, David (ed.). Potentialities. Tradução de Daniel Heller-Roazen. Stanford: Stanford University Press, 1999.

HELlER-ROAZEN, Daniel (ed.). Potentialities: collected essays - Giorgio Agamben. Stanford: Stanford University Press, 1999.

HOBBES, Thomas. Leviatã: ou a matéria, forma e poder de um Estado Eclesiástico e Civil. 2. ed. Tradução de Rosina D'Angina. São Paulo: Ícone, 2000.

HONESKO, Vitor Hugo Nicastro; HONESKO, Raquel Schlommer; BARBOSA, Tatiane Alves. $O$ estado de exceção como causa da corrupção no sistema político-constitucional brasileiro. Revista do Instituto dos Advogados de São Paulo, ano 9, n. 17, janeiro-junho 2006.

HONESKO, Vitor Hugo Nicastro. O totalitarismo neoliberal e a "democracia” brasileira: a construção do homo sacer tupiniquim. In: MACEDO, Paulo Emílio Vauthier (coord.). Direito e política: anais do II Congresso Brasileiro. Curitiba: Juruá, 2005.

HUMPHREYS, Stephen. Legalizing lawlesness: on Giorgio Agamben's state of exception. European Journal of International Law, 2006, 17(3).

JENKINS, Fiona. Bare life: asylum-seekers, Australian politics and Agamben's critique of violence. In: Autralian Journal of Human Rights. Vol. 10. No. 1. Disponível em http://www.austlii.edu.au/au/journals/AJHR/2004/18.html. 
KELSEN, Hans. O Problema da Justiça. Tradução de João Baptista Machado. São Paulo: Martins Fontes, 2003.

Teoria Pura do Direito. Tradução de João Baptista Machado. São Paulo: Martins Fontes, 1998.

Teoria geral do direiro e do estado. Tradução de Luís Carlos Borges. São Paulo: Martins Fontes, 2005.

KENNEDY, Ellen. Constitutional failure: Carl Schmitt in Weimar. Durham and London: Duke University Press, 2004.

KOHN, Margaret. Bare life and the limits of law. Theory\&Event, 2006, v. 9(2). Disponível em http://muse.jhu.edu/login?uri=/journals/tae/v009/9.2kohn.html.

LACAPRA, Dominick. Approaching limit events: siting Agamben. In: CALARCO, Matthew; DECAROLI, Steven (ed.). Giorgio Agamben: sovereignty and life. Stanford, California: Stanford University Press, 2007.

LACLAU, Ernesto. Bare life or social indeterminacy? In: CALARCO, Matthew; DECAROLI, Steven (ed.). Giorgio Agamben: sovereignty and life. Stanford, California: Stanford University Press, 2007.

LANCEROS, Ptaxi. M. Foucault: la pregunta por el poder. Revista de la Universidad de Deusto, Segunda Época, v. 43/1, enero-junio 1995.

LEVITT, Debora. Notes on media and biopolitics: 'notes on gesture'. In: CLEMENS, Justin; HERON, Nicholas, MURRAY, Alex (ed.). The work of Giorgio Agamben: law, literature, life. Edinburg University Press, 2008.

LOURENÇO, Frederico Ricardo de Ribeiro e. Poder e norma: Michel Foucault e a aplicação do direito. Porto Alegre: Nuria Fabris Ed., 2009. 
LOPES, José Reinaldo de Lima. $O$ direito na história: lições introdutórias. 2. ed. São Paulo: Max Limonad, 2002.

LÖWY, Michael. Walter Benjamin: aviso de incêndio: uma leitura das teses "Sobre o conceito de história”. Tradução de Wanda Nogueira Caldeira Brant. São Paulo: Boitempo, 2005.

LUKÁCS, Georg. História e consciência de classe: estudos sobre a dialética marxista. São Paulo: Martins Fontes, 2003.

MACEDO JR., Ronaldo Porto. Carl Schmitt e a Fundamentação do Direito. São Paulo: Max Limonad, 2001.

MCQUILLAN, Colin. The political life in Giorgio Agamben. Kritikos, v. 2, July 2005. Disponível em http://garnet.acns.fsu.edu/ nr03/mcquillan.htm.

MARCUSE, Herbert. Cultura e Sociedade. Tradução de Wolfgang Leo Mar, Isabel Maria Loureiro e Robespierre de Oliveira. Rio de Janeiro: Paz e Terra, 1997.

Eros e Civilização: Uma Interpretação Filosófica do Pensamento de Freud. 8. ed. Tradução de Álvaro Cabral. Rio de Janeiro: LTC Ed.

MARX, Karl. O capital. 3. ed. Tradução de Gabriel Deville. Bauru: EDIPRO, 2008.

MARX, Karl; ENGELS, Friedrich. A ideologia alemã. 3. ed. Tradução de Luis Cláudio de Castro e Costa. São Paulo: Martins Fontes, 2007. . Manifesto do partido comunista. São Paulo: Martin Claret, 2005.

MARKY, Thomas. Curso elementar de direito romano. 8. ed. São Paulo: Saraiva, 1985.

MARTINS, Jasson da Silva. Estado de exceção e biopolítica segundo Giorgio Agamben. Entrevista concedida em 4.9.2007. Instituto Humano Unisinos. Disponível em http://www.unisinos.br/ihu/index.php?option=com_noticias\&Itemid=18\&task. 
MATTHEW, Calarco; DECAROLI, Steven (ed.). Giorgio Agamben: sovereignty and life. Stanford: Stanford University Press, 2007.

MATTOS, Olgária. Modernidade: república em estado de exceção. Revista USP, setembro/outubro/novembro 2003.

MCQUILlAN, Colin. The Political Life in Giorgio Agamben. Disponível em http://garnet.acns.fsu.edu/ñr03/mcquillan.htm

MENEZES, Djacir. Os equívocos da noção de soberania. In: Carta mensal, Rio de Janeiro, v. 30 (355), Outubro 1984.

MILLS, Catherine. The philosophy of Giorgio Agamben. Montreal and Kingston: McGillQueen's University Press, 2008.

. Biopolitics, liberal eugenics, and nihilism. In: CALARCO, Matthew; DECAROLI, Steven (ed.). Giorgio Agamben: sovereignty and life. Stanford, California: Stanford University Press, 2007.

MINCA, Claudio. Giorgio Agamben and the new biopolitical nomos. Geografiska Annaler: Series B, Human Geography, 2006, v. 88(4).

MORRISON, Wayne. Filosofia do direito: dos gregos ao pós-mordenismo. Tradução de Jefferson Luiz Camargo. São Paulo: Martins Fontes, 2006.

MÜLLER, Friedrich. Constitucionalidade, legalidade, legitimidade. São Paulo: Max Limonad, 1999.

- As medidas provisórias no Brasil diante do pano de fundo das experiências alemãs. In: GRAU, Eros Roberto; FILHO, Willis Santiago Guerra (org.). Direito constitucional: estudos em homenagem a Paulo Bonavides. São Paulo: Malheiros. 
NANCY, Jean-Luc. Abandoned being. In: HOLMES, Brian (ed.). The birth to presence. Stanford: Stanford University Press, 1993.

. L’impératif catégorique. Paris: Flammarion, 1983.

. Corpus. Paris: Métailié, 2006.

NASCIMENTO, Milton Meira do. Dentro e fora da lei. Jornal de resenhas, n. 91, de abril de 2001 a novembro de 2002. São Paulo: Discurso Editorial, 2002.

NEGRI, Antonio. O Poder Constituinte: ensaio sobre as alternativas da modernidade. Tradução de Adriano Pilatti. Rio de Janeiro: DP\&A Ed., 2002.

. Il frutto maturo della redenzione. Disponível em http://www.generationonline.org/t/negriagamben.htm. Acessado em 5.8.2009.

. Giorgio Agamben: the discreet taste of the dialetic. In: CALARCO, Matthew; DECAROLI, Steven (ed.). Giorgio Agamben: sovereignty and life. Stanford, California: Stanford University Press, 2007

NEGRI, Antonio; HARDT, Michael. Império. 8. ed. Tradução de Berilo Vargas. Rio de Janeiro e São Paulo: Editora Record, 2006.

NORRIS, Andrew. The exemplary exception: philosophical and political decisions in Giorgio Agamben's Homo Sacer. In: Politics, metaphysics and death: essays on Giorgio Agamben. Durham and London: Duke University Press: 2005.

ODYSSEOS, Louiza; PETITO, Fabio. The international political thought of Carl Schmitt: terror, liberal war and the crisis of global order. London: Routledge, 2007.

OWENS, Patricia. Beyond 'bare life': refugees and the 'right to have rights'. Disponível em

http://www.allacademic.com/one/isa/isa09/index.php?cmd=isa09_search\&offset $=0 \&$ limit $=$ 5\&multi_search_search_mode $=$ publication\&multi_search_publication_fulltext_mod=fullte 
xt\&textfield_submit $=$ true\&search_module $=$ multi_search\&search $=$ Search\&search_field $=$ tit le_idx\&fulltext_search=Beyond+Bare+Life $\% 3 \mathrm{~A}+$ Refugees + and + the $+\%$ E2\%80\%9CRight + to + Have + Rights $\%$ E2\% $\% 0 \% 9$ D.

PALOMBELA, Gianluigi. Filosofia do direito. Tradução de Ivone Benedetti. São Paulo: Martins Fontes, 2005.

PATTON, Paul. Agamben and Foucault on biopower and biopolitics. In: CALARCO, Matthew; DECAROLI, Steven (ed.). Giorgio Agamben: sovereignty and life. Stanford, California: Stanford University Press, 2007.

PECORARO, Rossano. Compreender a atualidade através de Agamben. Entrevista $\begin{array}{lllll}\text { concedida } & \text { em } & \text { 4.3.2009. } & \text { Disponível }\end{array}$ http://www.ihu.unisinos.br/index.php?option=com_noticias\&Itemid=18\&task=detalhe\&id $=20360$.

PELBART, Peter Pál. Vida capital: ensaios de biopolítica. São Paulo: Iluminuras, 2003.

PINHEIRO, Paulo Sérgio. Escritos indignados: polícia, prisões e política no Estado autoritário (no 20. aniversário do regime de exceção, 1964-1984). São Paulo: Brasiliense, 1984 ,

Polícia e consolidação democrática: o caso brasileiro. In: São Paulo sem medo: um diagnóstico da violência urbana. Rio de Janeiro: Garamond, 1998.

RAMOS, Dircêo Torrecillas. Direitos fundamentais nas crises. In: MARTINS, Ives Gandra da Silva (coord.). As vertentes do direito constitucional contemporâneo. São Paulo: América Jurídica, 2002.

RASCH, William. From sovereign ban to banning sovereignty. In: CALARCO, Matthew; DECAROLI, Steven (ed.). Giorgio Agamben: sovereignty and life. Stanford, California: Stanford University Press, 2007. 
ROCHLITZ, Rainer. A filosofia de Walter Benjamin: o desencantamento da arte. Tradução de Maria Elena Ortiz Assumpção. Bauru: EDUSC, 2003.

ROUDINESCO, Elisabeth. Filósofos na tormenta: Canguilhem, Sartre, Foucault, Althusser, Deleuze e Derrida. Tradução de André Telles. Rio de Janeiro: Jorge Zahar Ed., 2007.

SAFATLE, Vladimir. Materialismo, imanência e política: sobre a teoria da ação de Giorgio Agamben. In: SEDLMAYER, Sabrina; GUIMARÃES, César; OTTE, Georg. O comum e a experiêncida da linguagem. Belo Horizonte: Editora UFMG, 2007.

SALDANHA, Nelson. O Pensamento Jurídico no Brasil. Rio de Janeiro: Forense, 1979. . O Poder Constituinte. São Paulo: Revista dos Tribunais, 1986.

SCHEUERMAN, William E. Between the norm and the exception: the Frankfurt School and the rule of law. Cambridge and London: The MIT Press, 1997.

. Carl Schmitt and the Road to Abu Ghraib. Constellations, Oxford, v. 13, n. 1, 2006.

SCHMITT, Carl. Legalidade e legitimidade. Tradução de Tito Lívio Cruz Romão. Belo Horizonte: Del Rey, 2007.

. Teologia política. Tradução de Elisete Antoniuk. Belo Horizonte: Del Rey, 2006.

O guardião da constituição. Tradução de Geraldo de Carvalho. Belo Horizonte:

Del Rey, 2007. . O conceito do político: Teoria do Partisan. Tradução de Geraldo de Carvalho. Belo Horizonte: Del Rey, 2008.

. The crisis of parliamentary democracy. Tradução de Ellen Kennedy. Cambridge: The MIT Press, 2000. 
. La dictadura. Tradução de José Diaz Garcia. Madrid: Alianza Editorial, 1985.

- Teoría de la Constitución. Tradução de Francisco Ayala. Madrid: Alianza Editorial, 1982.

SCHÜTZ, Anton. The fading memory of homo non sacer. In: CLEMENS, Justin; HERON, Nicholas; MURRAY, Alex (ed.). The work of Giorgio Agamben: law, literature, life. Edinburg University Press, 2008.

SCRAMIM, Susana; HONESKO, Vinícius Nicastro. In: Apresentação a AGAMBEN, Giorgio. O que é contemporâneo? E outros ensaios. Tradução Vinícius Nicastro Honesko. Chapecó: Argos, 2009.

SELIGMANN-SILVA, Márcio de. Ler o livro do mundo: Walter Benjamin - romantismo e crítica literária. São Paulo: Iluminuras, 1999.

SILVA, José Afonso da. A governabilidade num Estado Democrático de Direito. In: VALADÉS, Diego (Ed.). Gobernabilidad y constitucionalismo en América Latina. México: Universidad Nacional Autónoma de México, 2005.

. Curso de direito constitucional positivo. 23. ed. São Paulo: Malheiros, 2003

SLAIBI FILHO, Nagib. Estado de defesa e Estado de sitio: estudos e comentários. In: Revista Forense, v. 306.

TELES, Edson Luís de Almeida. Brasil e África do Sul: os paradoxos da democracia. Memória política em democracias com herança autoritária. Tese de doutorado, Acervo Dedalus, FFLCH, 20900020892, SBD-FFLCH-USP 281499, 2007.

THURSCHWELL, Adam. Specters of Nietzche: potential futures for the concept of the political in Agamben and Derrida. New York: Cardozo Law Review, 2003. Disponível em http://www.law.csuohio.edu/faculty/publications/search.php. 
VALADÉS, Diego. Consideraciones sobre gobernabilidad y constitucionalismo: estudio introductorio. In: VALADÉS, Diego (Ed.). Gobernabilidad y constitucionalismo en América Latina. México: Universidad Nacional Autónoma de México, 2005.

VILLANON, Pedro Cruz. Estados excepcionales y suspension de garantias. Madrid: Editorial Tecnos, 1984.

VIRNO, Paolo. General intellect, exodus and multitude. Archipélago, 2002. Disponível em http://www.generation-online.org/p/fpvirno2.htm.

WADIWEL, Dinesh. Animal by any other name? Patterson and Agamben discuss animal (and human) life. Borderlands e-journal, v. 3(1). Disponível em http://www.borderlands.net.au/vol3no1_2004/wadiwel_animal.htm.

WHYTE, Jessica. Its silent working was a delusion. In: CLEMENS, Justin; HERON, Nicholas; MURRAY, Alex (ed.). The work of Giorgio Agamben: law, literature, life. Edinburg University Press, 2008.

WOHLFARTH, Irving. On some jewish motifs in Benjamin. In: BENJAMIN, Andrew (ed.). The problems of modernity: Adorno and Benjamin. London and New York: Routledge, 1998.

ZARTALOUDIS, Thanos. Soulblind, or on profanation. In: CLEMENS, Justin; HERON, Nicholas; MURRAY, Alex (ed.). The work of Giorgio Agamben: law, literature, life. Edinburg University Press, 2008.

ZIZEK, Slavoj. Homo sacer as the object of the discourse of the university. Disponível em http://www.lacan.com/hsacer.htm.

Welcome to the desert of the real. New York: Verso, 2002b.

. ZIZEK, Slavoj. Violence. New York: Picador, 2008. 